\title{
A REVISION OF GUAREA (MELIACEAE)
}

\author{
T. D. PENNINGTON ${ }^{1} \&$ J. J. CLARKSON ${ }^{2}$
}

The species of Guarea F.Allam. ex L. (Meliaceae) are revised. Sixty-nine species are recognised, a key to the species is provided, all names are typified and descriptions of all species are given. A phylogenetic analysis based on ITS sequence data is discussed. Six new species and one new subspecies are described. Five new combinations for subspecies are made.

Keywords. Guarea, Meliaceae, neotropics, phylogeny, taxonomic revision.

\section{INTRODUCTION}

Guarea F.Allam. ex L. is the second largest genus (after Trichilia P.Browne) of American Meliaceae, with 69 species included in the present account. It is placed in the subfamily Melioideae (Pennington \& Styles, 1975; Muellner et al., 2003), where it is most closely related to two other small genera, Ruagea Karst. and Heckeldora Pierre (Muellner et al., 2006, 2008). Guarea is separated from all other genera by the combination of the pinnate leaves nearly always with a terminal bud which shows periods of growth between periods of dormancy, the flowers with 4 petals, stamens completely fused into a staminal tube bearing the anthers in the throat, the ovary supported on a broad stipitate nectary-disk and with a discoid style-head, the fruit a loculicidal capsule with fleshy seeds surrounded by a sarcotesta and the embryo with superposed cotyledons.

The related Ruagea and Heckeldora are easily separable. Ruagea differs in its leaves which lack the dormant apical bud, in having 5 imbricate sepals (mostly 4 sepals and always with open aestivation in Guarea), 5 petals (mostly 4 or 6 in Guarea), 3-locular ovary (mostly 4- or 6-locular in Guarea), seed with a swollen basal sarcotesta (absent in Guarea) and embryo with collateral cotyledons (nearly always superposed in Guarea).

Heckeldora differs in its leaves which lack the dormant apical bud, in having imbricate petals (nearly always valvate in Guarea), in its unilocular ovary with parietal placentas (mostly 4-6-locular with axile placentation in Guarea), and in the fruit which is a fleshy berry (always a loculicidal capsule in Guarea).

\footnotetext{
${ }^{1}$ Herbarium, Royal Botanic Gardens, Kew, Richmond, Surrey TW9 3AB, UK. E-mail: t.pennington@ kew.org

2 Jodrell Laboratory, Royal Botanic Gardens, Kew, Richmond, Surrey TW9 3AB, UK. E-mail: j.clarkson@kew.org
} 
The American species of Guarea are distributed from northwestern Mexico to northern Argentina. The majority of species occur in Amazonia but a substantial number extend into Central America, the West Indies and coastal Brazil. Virtually all species of Guarea are inhabitants of lowland rain forest below $1000 \mathrm{~m}$ altitude. A few Andean species, such as Guarea kunthiana, reach $2500 \mathrm{~m}$ altitude in wet montane forest and in the West Indies a few, such as G. jamaicensis and G. sphenophylla, are found in seasonally dry forest over limestone. All Guarea species are evergreen trees or treelets, even where they occur in a strongly seasonal climate as on the Pacific coast of Central America. Under these conditions they are confined to shady canyons, riversides and other situations with a plentiful supply of ground water.

The genus was last revised in Flora Neotropica (Pennington et al., 1981) and since that date a considerable number of new species have been published in local and regional accounts (Pennington \& Görts van Rijn, 1984; Pennington, 1986; Pennington \& Mori, 1993; Palacios, 1994; Pennington \& Edwards, 2001; Pennington \& Styles, 2001; Coronado, 2006; Pennington, 2006; Rodríguez, 2006; Palacios, 2007, Pennington \& Biggs, in press). In addition to the discovery of new species the boundaries of the genus itself have been refined. Recent molecular phylogenetic studies have shown that Guarea is now an exclusively American genus (Koenen \& de Wilde, 2012; Koenen et al., in prep.), and the African species are now considered to belong in two separate genera.

There are now 69 species in the genus compared with 37 in 1981. This includes 32 new species and a further six species due to the reassessment of the Guarea glabra complex. A total of 3500 new (post-1981) collections have been examined during this study, necessitating the revision of all the distribution maps. The new distribution maps presented here, which show the pre- and post-1981 ranges, demonstrate the imperfect state of knowledge of the genus in 1981. The maps are to be found on pp. 332-345.

In the Flora Neotropica treatment (Pennington et al., 1981), it was not possible to formally subdivide the genus on the basis of the morphological variation. However, the species were keyed out into two major groups based on flower size and the number of ovules in the ovary loculi. The significance of these groups has been tested here in a preliminary phylogeny based on sequence data from the ITS locus of ribosomal DNA, which shows that these characters are of little evolutionary significance.

\section{Phylogenetic Analysis}

\section{J. J. Clarkson, T. D. Pennington, G. Haynes, R. Engstrand, M. Kaye \& M. W. Chase}

When it was last revised (Pennington et al., 1981), the largely American genus Guarea contained a few African species. However, as a result of recent molecular phylogenetic studies (Koenen \& de Wilde, 2012; Koenen et al., in prep.), the African species are now regarded as two separate genera, leaving Guarea as exclusively American. On morphological grounds American Guarea was assumed to be a monophyletic group, based on a unique combination of several characters, namely the 
pinnate leaves with a terminal bud with intermittent growth, flowers with a complete staminal tube bearing stamens within the throat, the ovary supported on a broad nectar-secreting stipe and the loculicidal capsule containing fleshy seeds with a fleshy sarcotesta. In order to test this proposed monophyly three related genera were used as outgroups.

1 Ruagea (Andean South America). This is morphologically the most similar American genus. It has always been associated with Guarea, and at one time was included within it (de Candolle, 1878).

2 Heckeldora (West Africa). Also morphologically similar to Guarea and formerly included within it (Harms, 1940).

3 Turraeanthus (West Africa). Differs from Guarea only in the fusion of the petals and a few other minor characters and always regarded as a close relative of Guarea.

All three outgroups were included in the tribe Guareeae in a comprehensive generic review (Pennington \& Styles, 1975) and in a broadly based molecular phylogenetic study (Muellner et al., 2008). Forty-seven accessions representing 43 species, out of a total of 69 known species, were included in this study. These cover most of the range of variation and all of the geographical range of the genus. For a list of herbarium specimens sampled see Appendix 1.

\section{Materials And Methods}

For extractions, a maximum of $0.2 \mathrm{~g}$ of dried material was used. DNA was extracted using a modified Doyle \& Doyle (1987) 2X CTAB method. DNA was precipitated in isopropanol $\left(-20^{\circ} \mathrm{C}\right)$ for two weeks and then re-suspended in $1.55 \mathrm{~g} / \mathrm{ml}$ caesium chloride/ethidium bromide. Samples were then purified using a density gradient, followed by removal of the ethidium bromide with butanol and caesium chloride by dialysis; all DNAs were stored in $10 \mathrm{mM}$ TE ( $\mathrm{pH} 8)$.

The ITS region sequenced for this investigation is the standard ribosomal locus used in plant molecular phylogenetics. It therefore includes a small portion of the 3-prime end of the $18 \mathrm{~S}$ gene, the internal transcribed spacer (ITS) 1, the entire 5.8S gene, the ITS2 and a small portion of the 5-prime end of the 26S gene. Many DNA extracts showed degradation due to the slow drying process associated with the production of herbarium sheets. Therefore, we amplified the ITS region in two halves. Primers ITS5-Mel to ITS2-Mel produced a fragment that was approximately 360 bps. Primers ITS 3 to ITS4 produced a fragment that was approximately $390 \mathrm{bps}$. The overlap between these fragments was small (approximately $15 \mathrm{bps}$ ) so they were analysed as interleaved data blocks and not forced into contigs.

Target regions were amplified in a Gene Amp ${ }^{\mathrm{TM}} 9700$ PCR system (ABI, Applied Biosystems, Inc., Warrington, Cheshire, UK) using ReddyMix PCR Mastermix at $2.5 \mathrm{mM} \mathrm{MgCl} 2$ concentration (AB gene, Epsom, Surrey, UK). DMSO was added (4\% of total reaction volume) in order to eliminate the secondary structure associated with 
TABLE 1. Primers used in this study

\begin{tabular}{lll}
\hline \hline Name & Sequence & Reference \\
\hline ITS2-Mel & GCT ACG TTC TTC ATC GAT GC & Muellner et al. (2005) \\
ITS5-Mel & GGA AGG AGA AGT CGT AAC AAG G & Muellner et al. (2005) \\
ITS3 & GCA TCG ATG AAG AAC GCA GC & Baldwin (1992) \\
ITS4 & TCC TCC GCT TAT TGA TAT GC & Baldwin (1992) \\
\hline \hline
\end{tabular}

ribosomal DNA. Table 1 gives details of the primers used. The region was amplified using the following program: 2 minutes at $94^{\circ} \mathrm{C}$ followed by 30 cycles of 1 minute at $94^{\circ} \mathrm{C}, 1$ minute at $50^{\circ} \mathrm{C}$, and 1.5 minutes at $72^{\circ} \mathrm{C}$ (followed by a final extension of 6 minutes at $72^{\circ} \mathrm{C}$ ). All taxa could be sequenced directly from the PCR products and so no bacterial cloning was required.

Prior to cycle sequencing, PCR products were cleaned using NucleoSpin ${ }^{\circledR}$ Extract II mini-columns (Macherey-Nagel, Duren, Germany) following the manufacturer's protocols. Precipitation in ethanol (using both sodium acetate and EDTA) was used to clean cycle sequencing products. Cleaned samples were analysed on an Applied Biosystems Inc. (ABI) 3730 capillary DNA sequencer using Big Dye terminator v3.1 chemistry, following the manufacturer's protocols (ABI).

The raw sequences were edited and assembled using Sequencher version 4.1 (Gene Codes, Inc., Ann Arbor, Michigan, USA). The initial alignment was provided by Clustal X2.0 (The Conway Institute, University College Dublin, Ireland) before being further refined by eye. Gaps were coded as missing data (rather than an additional character state) and thus excluded from the analysis.

\section{Parsimony analysis methods}

PAUP version 4.0b (Swofford, 2001) was used for parsimony analysis. For full searches, 50 terminals were included. Heuristic searches were performed using tree bisection-reconnection (TBR) branch swapping and 1000 replicates of random taxon addition were performed with 10 trees held at each step to reduce time searching for suboptimal trees (Salamin et al., 2003). All character transformations were treated as equally likely and unordered (Fitch, 1971). DELTRAN character optimisation was used to illustrate branch lengths throughout (due to reported errors with ACCTRAN optimisation in PAUP v.4.0b). To assess internal support, 1000 bootstrap replicates (Felsenstein, 1985) were performed with equal weights using TBR branch swapping with 10 trees held at each step and simple taxon addition.

\section{Bayesian analysis methods}

Bayesian analysis was performed using MrBayes version 3.1.2 (Huelsenbeck \& Ronquist, 2001). An HKY85 model was specified in which all transitions and 
transversions have potentially different rates. More complex models were also used, but these provided the same tree with similar posterior probabilities (PP; results not shown). Analyses were performed with 500,000 generations of Monte Carlo Markov chains with equal rates and a sampling frequency of 10 . Three separate runs were performed to ensure that the analysis was producing consistent results. Microsoft Excel was used to plot generation number against $\ln \mathrm{L}$ to find the 'burn in'. Trees of low PP were deleted, and all remaining trees were imported into PAUP v.4.0b. A majority rule consensus tree was produced showing the frequencies (i.e. posterior probabilities) of all observed bi-partitions.

\section{Parsimony analysis results}

The total number of characters was 697, of which 312 were variable $(44.76 \%)$ and 182 $(26.11 \%)$ were potentially parsimony informative. Analysis produced 2171 equally most-parsimonious trees (length $=702$ steps; consistency index, CI (including autapomorphies) $=0.64$; retention index, $\mathrm{RI}=0.79$ ). One of the most-parsimonious trees with its Fitch branch lengths (DELTRAN optimisation) is shown in Fig. 1. This tree is presented in two parts (A and B) but is the result of a single analysis. Clades not found in all shortest trees are marked with arrowheads. Bootstrap percentages (BP) equal to or greater than 50 that are consistent with the strict consensus tree are shown below each branch.

\section{Bayesian analysis results}

The 'burn-in', 2500 trees of low likelihood, were omitted from the consensus tree. Bayesian analysis produced the same overall topology as did parsimony (Fig. 1 versus Fig. 2). All of the clades that differ have low BP in parsimony analysis and low PP in the Bayesian tree, although the general trend is that the Bayesian posterior probabilities are higher than bootstrap percentages.

As mentioned the trees only differ for clades which are weakly supported (both BP and PP). A typical example is the sister group of the well-supported (BP 98, PP 1.0) small Central American clade consisting of Guarea macrocalyx, G. tafae-malekui and G. zarceroensis. In both analyses the Central American clade has three South American successive sister species (Guarea pubescens, G. subandina and G. michel-moddei). However, the branching order of these successive sisters is different in the two analyses. Each has no bootstrap support in the parsimony analysis (Fig. 1) and only weak PPs $(0.22,0.37)$ in the Bayesian analysis (Fig. 2) and so this is not a hard incongruence.

\section{Monophyly and InfRA-Generic Classification}

The analysis confirms the monophyly of American Guarea, and demonstrates that two ancestral South American species, G. silvatica and G. anomala, form early diverging isolated lineages with long branch lengths (Fig. 1A). In contrast the 


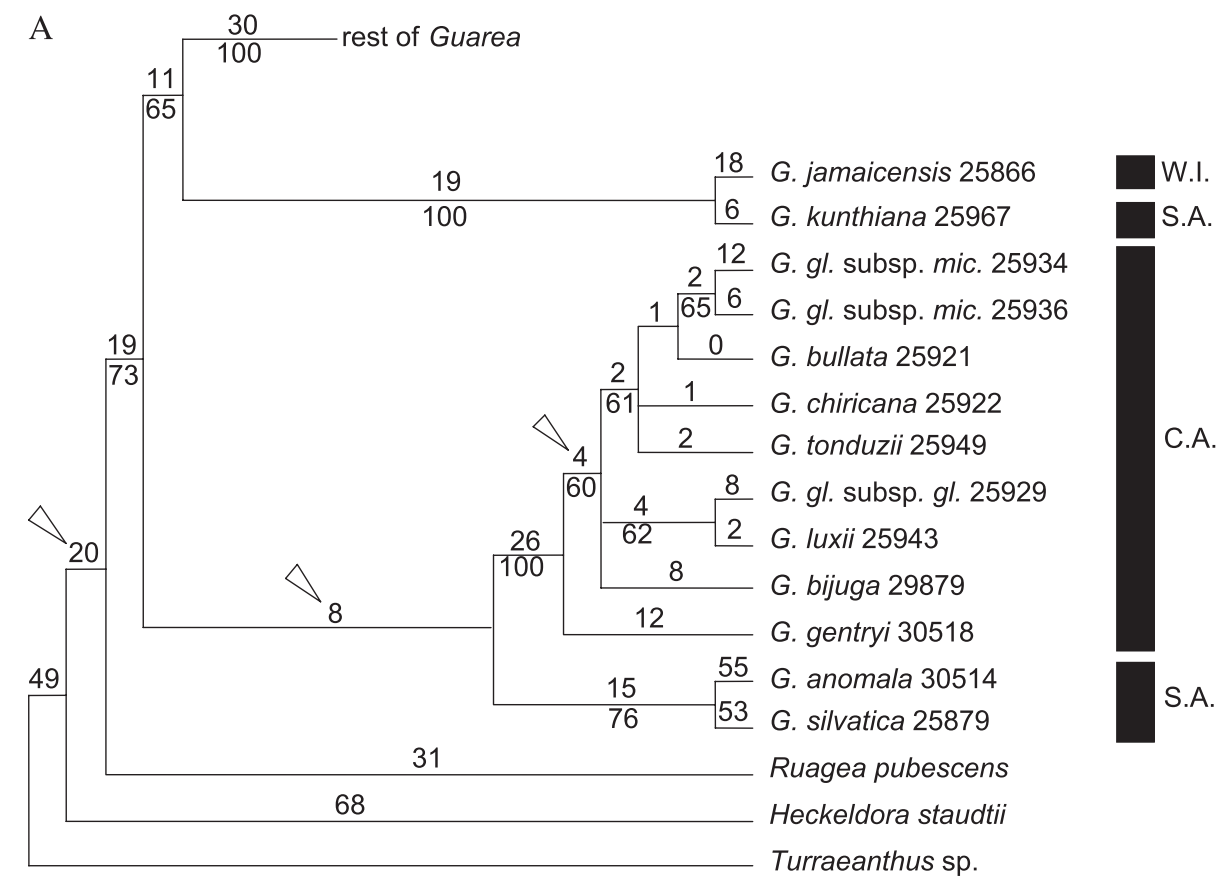

FIG. 1A. Part of one of the most-parsimonious trees for Guarea obtained from analysis of ITS sequences. Bootstrap values, above $50 \%$, are shown below branches and branch lengths are shown above branches. Arrows indicate groups not present in all shortest trees. The black bars indicate distribution data with S.A. representing South America, C.A. representing Central America and W.I. representing the West Indies. Species with subspecies are represented by the following abbreviations: $G$. gl. subsp. gl. represents G. glabra subsp. glabra and G. gl. subsp. mic. represents G. glabra subsp. microcarpa. Kew DNA bank numbers are shown after each taxon name.

majority of the remaining species are located in two major clades, one South American and the other Central American, whose constituent species are on very short branch lengths. The major division of the genus therefore falls along geographical and not morphological lines. In the most recent monograph of the genus (Pennington et al., 1981), no formal morphological infra-generic classification was proposed. This was because of an absence of unique characters which could be used to define species groups. All species were defined on the basis of unique combinations of often quantitative characters, without distinct character states. However, in the key to the species there was an informal division of the genus based on the size of the flower, the number of ovary locules and number of ovules (flowers $<10 \mathrm{~mm}$ long, ovary 4-locular and locules 1-ovulate versus flower $>10 \mathrm{~mm}$ long, ovary 4-10-locular and locules 2-ovulate). If these characters are placed onto a phylogenetic tree (Fig. 1B or Fig. 2), they do not support any monophyletic groups, as both character states are distributed throughout the large South American clade, so any formal arrangement based on them would have no evolutionary basis. 


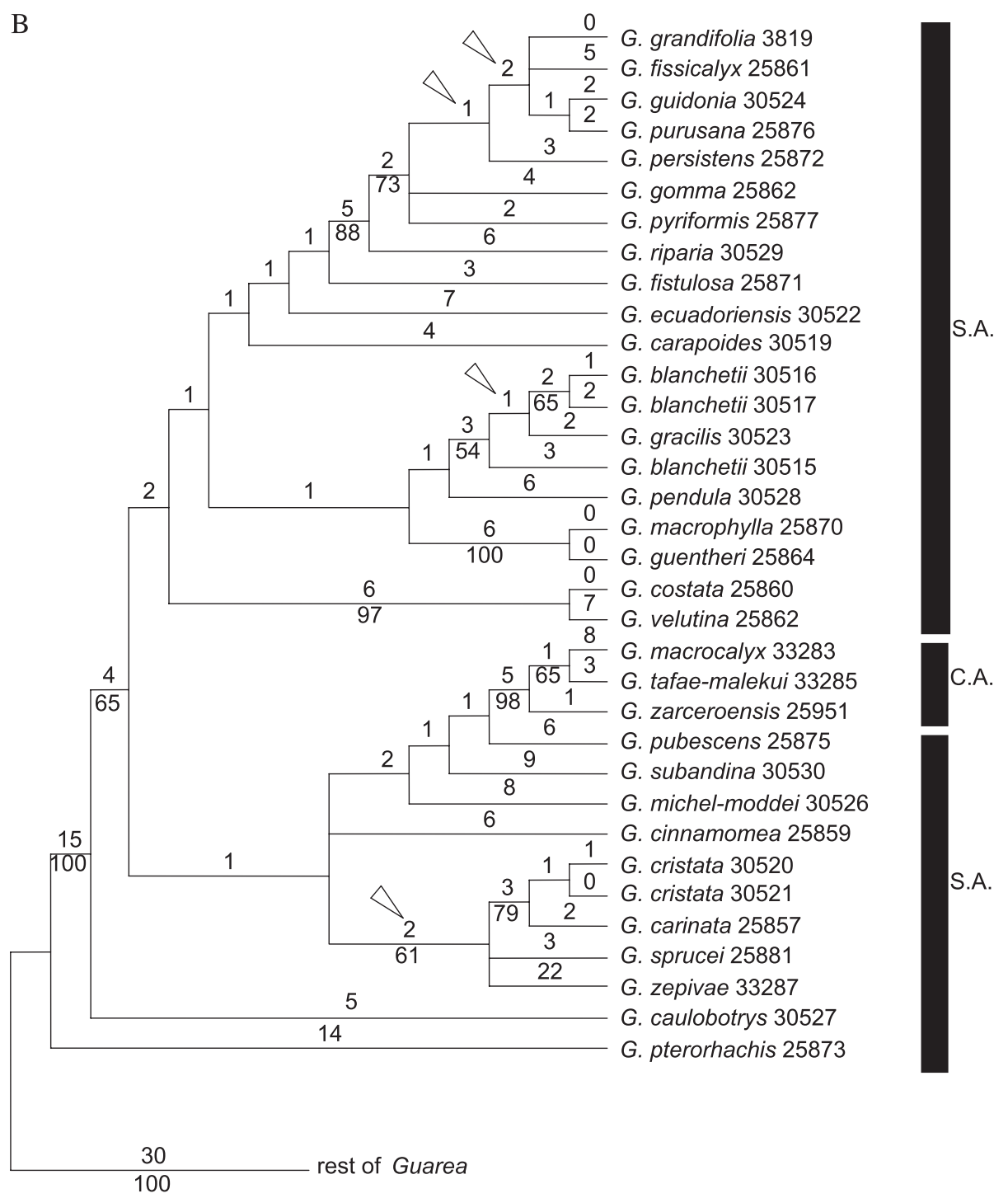

FIG. 1B. Part of one of the most-parsimonious trees for Guarea obtained from analysis of ITS sequences. Bootstrap values, above 50\%, are shown below branches and branch lengths are shown above branches. Arrows indicate groups not present in all shortest trees. The black bars indicate distribution data with S.A. representing South America and C.A. representing Central America. Kew DNA bank numbers are shown after each taxon name.

It should be noted that the genus Guarea is monophyletic as demonstrated by most previous studies (e.g. Muellner et al., 2006, 2008). This can be contrasted with the study of Fukuda et al. (2003) in which Guarea was not monophyletic although this unusual result was probably due to insufficient taxon sampling and also a lack of informative characters. 


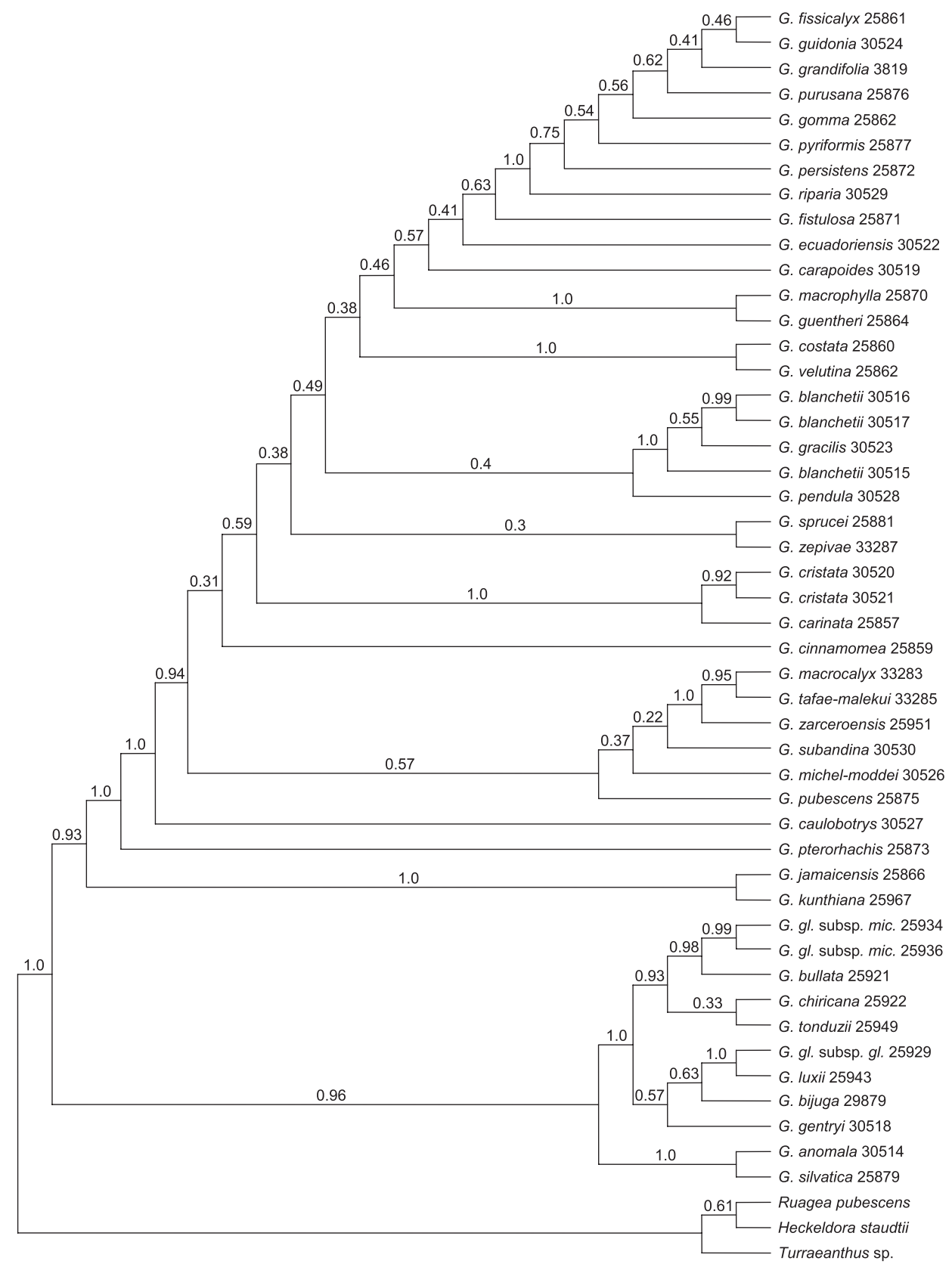

FIG. 2. Bayesian analysis of Guarea using ITS sequences. Tree shown is a consensus of 47,500 trees with posterior probabilities shown above branches. 


\section{SPeCies Delimitation}

Where several individuals of the same species were sampled, they were found to have very similar ITS sequences (e.g. Guarea cristata, G. glabra subsp. microcarpa), lending support to the morphological species delimitation used in this monograph. Three accessions of Guarea blanchetii were sampled and a high amount of intra-species variation was detected (each of the accessions in Fig. 1B has autapomorphies). These data also show that the species might not be monophyletic due to placement of Guarea gracilis. However, the embedding of Guarea gracilis within G. blanchetii is not present in all shortest trees (Fig. 1B) so this question is unresolved. Additionally this relationship receives only weak support (PP 0.55) in the Bayesian analysis (Fig. 2).

There are a few obviously morphologically distinct species within the genus, and it is significant that the ITS phylogeny confirms their isolated position, as they all occur at the end of long branches. They are Guarea silvatica, G. anomala, G. jamaicensis, G. kunthiana and G. pterorhachis. In contrast, the remaining species in both the South American and Central American clades are separated by short branch lengths, suggesting a more recent rapid radiation.

The most useful morphological differences between Guarea species are in the fine structure of the fruit (e.g. ornamentation of the pericarp) and in the fruit size. This contrasts with the general uniformity in vegetative and floral characters. It is clear from the present analysis, however, that species with large differences in the size and ornamentation of the fruit are often separated by very short genetic distance. For example, Guarea riparia (small, smooth fruit), G. fistulosa (medium-sized, strongly ribbed fruit) and $G$. ecuadoriensis (large smooth fruit) are genetically close. Just as gross fruit characters are of little value in determining family relationships (e.g. Meliaceae containing capsules, berries and drupaceous fruits), so at the species level it appears that fine fruit structure is of little value in determining relationships.

The low sequence divergence between species in the South American and Central American clades may account for the difficulty in morphological species delimitation due to insufficient time for morphological divergence. Similar patterns of recent rapid radiation have been postulated for other genera of tropical American trees, for example Guatteria Ruiz \& Pav.: Annonaceae (Erkens et al., 2007), Inga Mill: Leguminosae (Richardson et al., 2001), Aglaia Lour. (compare Muellner et al., 2005, 2008) and Trichilia P.Browne: Meliaceae (Pennington et al., in prep.).

The South American clade (Guarea grandifolia to G. pterorhachis) is predominantly Amazonian, the only exceptions being a small group of coastal Brazilian species (G. blanchetii, G. gracilis and G. pendula), a small group of species confined to Costa Rica (G. zarceroensis, G. macrocalyx and G. tafae-malekui) and G. caulobotrys and G. pyriformis (coastal Pacific Colombia, Panama and Costa Rica). Several of the widespread Amazonian species now extend into Panama and Costa Rica (e.g. Guarea pterorhachis, G. macrophylla, G. guidonia, G. grandifolia).

The Central American clade (Guarea glabra to G. gentryi) consists entirely of G. glabra and its close relatives. Most of these species were previously included in 
a broadly defined and widely distributed Guarea glabra (Pennington et al., 1981) within which they were treated as informal 'races'. Recent multivariate analysis of the Central American component of the group (Coronado, 2003) showed that these races were morphologically discrete, at least in morphospace, and should be recognised as distinct species, a course which has been followed in some cases in this revision. The ITS phylogeny sheds an interesting light on the relationships of the species within this complex. It shows that different accessions of Guarea glabra are paraphyletic with respect to G. luxii and G. bijuga. This suggests that these two splits from what was formerly regarded as a single variable species may have arisen from the wider Guarea glabra.

The ITS phylogeny shows that the components of the Guarea glabra complex comprise a group of closely related taxa with little genetic distance between them. For example, only four substitutions separate Guarea bullata, G. chiricana and G. tonduzii, far less than the distance separating two accessions of G. glabra subsp. microcarpa. The problem remains of whether to recognise these taxa as distinct species, or as a single species divided into several subspecies, or a single species with informal races. In view of the poor morphological distinction between some of the component taxa (many intermediate specimens), a middle course has been taken, with the most morphologically distinct taxa being recognised at the species level, while the less distinct are retained as subspecies within the wider Guarea glabra. The decision is a practical one which does not necessarily strictly follow the ITS phylogeny results. Unfortunately it was not possible to include samples of this complex from the West Indies and northern South America which are required to complete this picture. This preliminary analysis highlights the importance of sampling throughout the range of a complex like Guarea glabra and its relatives before making taxonomic decisions.

The present-day Guarea flora of Central America therefore comprises three elements:

1 The Guarea glabra complex (G. glabra, G. bullata, G. chiricana, G. tonduzii, G. luxii, G. bijuga, G. gentryi) which, together with $G$. anomala and $G$. silvatica, form a sister group to the whole of the rest of Guarea with a relatively ancient origin.

2 Those species which have arisen more recently from the South American stock, which are now confined to Costa Rica (Guarea macrocalyx, G. tafae-malekui, G. zarceroensis).

3 South American species with slight range extensions into Panama or Costa Rica, such as Guarea guidonia, G. pterorhachis and G. macrophylla.

\section{The Divergence of Species}

In our analyses Guarea silvatica and G. anomala are on long branches (with 53 and 55 substitutions respectively in the parsimony tree; Fig. 1A). The two species appear to have diverged long ago from all other species sampled (as judged by branch 
lengths). They are also distinctive species morphologically and each has a unique character or combination of characters. Guarea silvatica lacks the terminal leaf bud (present in nearly all species of the genus), has imbricate petals (usually valvate), a bony seed coat (usually fleshy) and an embryo with collateral cotyledons (nearly always superposed).

Guarea anomala has alternate leaflets (usually opposite) and lacks the terminal leaf bud, has unusual venation, and flowers with 3 petals (usually 4-6). Other morphological data, such as the complete staminal tube with the anthers inserted within the throat, the ovary structure, and the DNA sequence data, unequivocally support both species belonging in Guarea (BP 73, PP 1.0) but their uniqueness in the genus is noteworthy. We were able to add another representative of Guarea silvatica from a published project on DNA barcoding (Gonzalez et al., 2009) to test the position of our sample. Analyses showed that this published sequence was nearly identical, and sister, to our sample (data not shown). The few substitutions that differed are not surprising due to the great geographical distance between the two collection localities (our sample was collected in Brazil (Manaus) and Gonzalez et al. (2009) collected in French Guiana).

The large Central American clade consists of nine taxa on a relatively long branch (26 substitutions in Fig. 1A) but there is much less variation between taxa (e.g. only four substitutions separate Guarea bullata, G. chiricana and G. tonduzii). This suggests the long distance dispersal of an ancestral species to Central America followed by a recent radiation of the extant taxa.

Guarea pterorhachis, G. jamaicensis and G. kunthiana are all on long branches and are successive sisters to the South American clade. They are the earliest diverging lineages within the clade and therefore may have some ancestral characteristics of the group. Guarea pterorhachis is separated by 29 substitutions $(14+15)$ from the 'core' South American clade (Fig. 1). It differs from all other species of the genus in its broadly winged leaf rhachis and other rarely encountered floral characters. Guarea jamaicensis is separated by 67 substitutions $(18+19+30)$ from the Guarea pterorhachis branch. Guarea jamaicensis is found only in Jamaica, along with G. glabra, and since these two species are not related they must represent two separate colonisation events. It is easily recognised by the small rounded leaflets. Guarea kunthiana has 55 substitutions $(6+19+30)$ from the G. pterorhachis branch. This species has a very characteristic leaf venation and colour which enable it to be readily identified in the vegetative state, although its floral and fruit structure is typical of the genus. The remaining species within the South American clade are on very short branches suggesting recent speciation. This is by far the largest clade in the genus with 35 species sampled in this phylogenetic analysis. Within the South American clade there is a small and well-supported Central American clade (BP 98, PP 1.0) which consists of Guarea macrocalyx, G. tafae-malekui and G. zarceroensis. This small Central American group appears to be recently descended from the South American group (according to the short branch lengths) and its ancestors must have dispersed to Central America and then speciated into the three extant species. 
Notes on the Systematic Treatment, Abbreviations, etc.

Species arrangement for species 1-42 follows the order indicated by the ITS phylogeny (Fig. 1A \& 1B). The remaining species are in alphabetical order (no ITS sequence data available).

Descriptions and measurements of vegetative characters are from dried specimens. Twig diameter is measured $10-20 \mathrm{~cm}$ below the shoot apex on a fertile shoot. Leaf measurements are from fertile specimens, unless otherwise stated. Descriptions and measurements of floral characters are from rehydrated specimens or specimens preserved in spirit.

Full species descriptions are given only to new species, species described since 1981, or species imperfectly known in 1981. All other species are given an abbreviated description.

\section{Specimen citation in the text}

Collections examined means that all specimens (pre and post 1980) seen are cited except for type specimens which are listed after the publication details. Representative additional collections means that only one specimen (post 1980) from each major political division of a country is cited. Additional collections examined means all specimens (post 1980) are cited. All specimens seen in this study are cited in the List of Exsiccatae.

Geographical coordinates are given as 1 degree squares, e.g. NW1067 means $10^{\circ} \mathrm{N}, 67^{\circ} \mathrm{W}$.

The List of Exsiccatae contains mainly collections made after 1980, plus a few earlier ones mentioned in the text, such as types.

\section{Systematic Treatment}

Guarea ('Guara') F.Allam. in L., Mant. 150, 228 (1771), nom. cons.; C.DC. in Mart., Fl. Bras. 11(1): 181 (1878); C.DC. in A.DC. \& C.DC., Monogr. Phan. 1: 542 (1878); Harms in Engl. \& Prantl, Nat. Pflanzenfam., ed. 2, 19b1: 129, t. 31, figs R-X (1940), p.p.; T.D.Penn. \& Styles, Blumea 22: 494, fig. 12a, b (1975), p.p.; T.D.Penn. in T.D.Penn. et al., Flora Neotrop. 28: 255 (1981); T.D.Penn. \& Görts, Fl. Suriname 5(1): 519 (1984); T.D.Penn., Bol. Técn. Centro Pesq. Cacau 143: 1 (1986); W.Palacios, Novon 4: 155 (1994); M.E.Morales, Revista Acad. Colomb. Ci. Exact. 22(82): 335 (1998); T.D.Penn. \& K.S.Edwards, Fl. Venez. Guayana 6: 528 (2001); T.D.Penn. \& Styles, Fl. Nicaragua 2 (Meliaceae): 1419 (2001); Coronado, Novon 16: 462 (2006); T.D.Penn., Rodriguesia 57(2): 209 (2006); Al.Rodr., Lankesteriana 6: 101 (2006); W.Palacios, Fl. Ecuador 82, Fam. 98, Meliaceae: 1 (2007). - Type species: Guarea trichilioides L. (= Guarea guidonia (L.) Sleumer). For synonymy see T.D.Penn. in T.D.Penn. et al., Fl. Neotrop. 28: 255 (1981). 
Trees or treelets. Bud scales absent. Indumentum of simple hairs. Leaves nearly always paripinnate with a terminal bud usually showing intermittent growth, rarely without a terminal bud, rarely alternate. Leaflets sometimes glandular-punctate or -striate. Inflorescence axillary or clustered immediately below the leaves, or ramiflorous on larger branches or cauliflorous, a panicle, often with cymose branches (thyrse), raceme or spike. Flowers unisexual, plant dioecious. Calyx with an almost entire margin or shallowly to deeply 3-7-lobed, aestivation open. Petals (3-)4-6(-7), free, nearly always valvate, rarely slightly imbricate. Stamens completely united into a cylindrical staminal tube, sometimes contracted at the throat, margin entire, crenate or with short truncate or emarginate lobes; anthers (7-)8-12(-14), glabrous, inserted within the throat of the staminal tube, completely included or partly exserted, alternating with the lobes, antherodes similar, smaller, without pollen. Nectary shortto long-stipitate, nearly always expanded to form a collar below the ovary. Ovary $2-$ 10(-14)-locular, locules with 1-2(-4) superposed ovules, style-head discoid, pistillode smaller, less swollen, with well-developed non-functional ovules. Fruit a 2-10(-14)valved loculicidal capsule, locules 1-2(-4)-seeded; pericarp leathery or woody, endocarp thin, cartilaginous. Seed often shaped like the segment of an orange, with a thin fleshy sometimes vascularised sarcotesta. Embryo with thick plano-convex, superposed or rarely collateral cotyledons; radicle abaxial, extending to the surface; when cotyledons collateral then radicle apical. Endosperm absent.

Distribution. Sixty-nine described species in tropical America.

\section{Key to the species of Guarea}

1a. Petals generally 4-10 mm long, ovary (2-)4-6(-9)-locular, locules 1-ovulate, capsule (3-)4-6(-9)-valved, valves 1 -seeded

1b. Petals generally $10-20 \mathrm{~mm}$ long, ovary 2-12-locular, locules with 2(-4) superposed ovules, capsule 4-12-valved, valves with 1-2(-4) superposed seeds

2a. Capsule at least $3.5 \mathrm{~cm}$ long

2b. Capsule usually $1-2.5 \mathrm{~cm}$ long, never more than $3.5 \mathrm{~cm}$ long

3a. Leaves without a terminal bud, ovary 2-3(-4)-locular, glabrous, capsule constricted between the seeds

1. G. silvatica

3b. Leaves with a terminal bud, ovary (3-)4-6(-7)-locular, pubescent or strigose, capsule not constricted between the seeds

4a. Capsule 7-8 cm long, prominently longitudinally ribbed (ribs $3-4 \mathrm{~mm}$ high)

59. G. megacostata

4b. Capsule $3.5-6.2 \mathrm{~cm}$ long, smooth or only faintly lined 5

5a. Secondary veins 7-11 pairs, petals 6-7.5 $\mathrm{mm}$ long 47. G. convergens

5b. Secondary veins $12-18$ pairs, petals $8-14 \mathrm{~mm}$ long 
6a. Petals 8-12 $\mathrm{mm}$ long, inflorescence $15-40 \mathrm{~cm}$ long, capsule $\leq 4 \mathrm{~cm}$ long 37. G. gomma

6b. Petals $11.5-14 \mathrm{~mm}$ long, inflorescence $3-15 \mathrm{~cm}$ long, capsule $5-6.2 \mathrm{~cm}$ long 18. G. cinnamomea

7a. Tufts of hair present in the axils of the secondary veins on leaflet lower surface

7b. Axillary hair tufts absent 8

8a. Leaflets usually glabrous (apart from hair tufts in vein axils), petals $4-9 \mathrm{~mm}$ long, inflorescence a simple panicle, with a few lateral branches

6. G. glabra

8b. Lower leaflet surface sparsely and minutely appressed puberulous with pale whitish hairs, petals $3-4 \mathrm{~mm}$ long, inflorescence a profusely branched panicle, usually with several branches from the base

3. G. gentryi

9a. Leaves without a terminal bud, leaflets alternate, petals 3-4 2. G. anomala

9 b. Leaves with a terminal bud, leaflets opposite, petals $4-6$ 10

10a. Petiole 1-2 mm long, basal pair of leaflets greatly reduced, $1-4.2 \times 1-3.2 \mathrm{~cm}$, broadly ovate to suborbicular 66. G. subsessilifolia

10b. Petiole at least $2 \mathrm{~cm}$ long, basal pair of leaflets not greatly reduced, not broadly ovate or suborbicular 11

11a. Leaflets $6-14.2 \times 0.9-2.8 \mathrm{~cm}, 5-6$ times as long as broad, narrowly elliptic, species confined to rocky riversides 35. G. riparia

11b. Leaflets broader (less than 5-6 times as long as broad), species not confined to rocky riversides 12

12a. Twigs hollow, calyx persistent in young fruit, pedicel $5-6(-10) \mathrm{mm}$ long 38. G. persistens

12b. Twigs not hollow, calyx not persistent, pedicel shorter 13

13a. Fruit smooth 14

13b. Fruit ribbed, winged or tuberculate 34

14a. Mature fruit tomentose, pubescent or puberulous __ 15

14b. Mature fruit glabrous 25

15a. Lower lamina with dense crisped matted puberulous hairs, petals c. $12.5 \mathrm{~mm}$ long, fruit densely puberulous

50. G. crispa

15b. Indumentum of lower lamina not of dense crisp matted puberulous hairs, petals not more than $12 \mathrm{~mm}$ long, usually much less, fruit puberulous or not 16

16a. Petiole and rhachis soon becoming woody, leaflets $6.5-8.5 \mathrm{~cm}$ long, broadly elliptic to obovate, apex obtuse or rounded, c.2 times as long as broad, coriaceous, inflorescence 2-6-flowered, $2-3 \mathrm{~cm}$ long

11. G. jamaicensis 
16b. Petiole and rhachis not woody (except when old), leaflets usually longer, if as small then at least 3 times as long as broad, not coriaceous and with a much longer many-flowered inflorescence 17

17a. Lower lamina pubescent or puberulous _ـ 18

17b. Lower lamina \pm glabrous 21

18a. Tertiary veins numerous, fine, parallel, ovary short, rounded at the apex, densely long-strigose, capsule depressed-globose or globose, usually coarsely pubescent

21. G. pubescens

18b. Tertiary veins not finely parallel and oblique, ovary tapering at the apex, pubescent, capsule pyriform to globose, minutely puberulous or shortly pubescent 19

19a. Young shoots, inflorescence and lower lamina with yellowish pubescence, capsule pyriform, $2.3-3 \mathrm{~cm}$ long, minutely puberulous, pericarp $2-4 \mathrm{~mm}$ thick

36. G. pyriformis

19b. Indumentum of young shoots, inflorescence and lower lamina not yellowish, capsule globose, or if pyriform then pericarp 1-2 mm thick 20

20a. Young shoots golden-tomentose, leaves coriaceous, petals $8-12 \mathrm{~mm}$ long, capsule globose, $1.5-2.8 \mathrm{~cm}$ diam., sparsely to densely pubescent, pericarp $1.5-3 \mathrm{~mm}$ thick

7. G. tonduzii

20b. Young shoots minutely puberulous to pubescent, leaves not coriaceous, petals mostly 6-9 mm long, capsule globose or pyriform, $0.75-2.5(-3.5) \mathrm{cm}$ long, minutely puberulous to pubescent, pericarp 1-2 mm thick 28. G. macrophylla

21a. Tertiary veins numerous, fine, parallel, oblique, ovary short, rounded at the apex, densely long-strigose, capsule depressed-globose or globose, usually coarsely pubescent

21. G. pubescens

21b. Tertiary veins not finely parallel and oblique, often obscure, ovary tapering at the apex, pubescent or strigose, capsule pyriform to globose, minutely puberulous or shortly pubescent 22

22a. Leaves with indeterminate apical growth, petals $4-5$, anthers nearly always 8

23

22b. Leaves without indeterminate apical growth, petals $4-6$, anthers $8-11 \_24$

23a. Inflorescence a widely branched panicle with long, weak, slender axes, subglabrous

64. G. scabra

23b. Inflorescence little-branched, pubescent or puberulous _ 28. G. macrophylla

24a. Leaflets usually oblong, secondary veins $12-18$ pairs, petals $8-12 \mathrm{~mm}$ long, fruit $2.5-4 \mathrm{~cm}$ long

37. G. gomma

24b. Leaflets usually elliptic, secondary veins mostly $10-12$ pairs, petals $7-8 \mathrm{~mm}$ long, fruit $1.5-2.2 \mathrm{~cm}$ long

41. G. fissicalyx 
25a. Leaflets mostly $(5.6-) 8-11.3(-14.5) \times(1.5-) 2.5-3.6(-4) \mathrm{cm}$, secondary veins 12-18 pairs 5. G. luxii

25b. Leaflets larger, secondary veins usually fewer 26

26a. Fruit dark brown, shining, usually with numerous pale lenticels

26b. Fruit red or pink, often rough-skinned, with or without lenticels

40. G. guidonia

27a. Whole plant glabrous, leaflets usually $6.7-12 \mathrm{~cm}$ broad 4. G. bijuga

27b. Young shoots and lower leaflet surface pubescent (at least when young), leaflets usually $3-8 \mathrm{~cm}$ broad 28

28a. Venation impressed on the upper leaflet surface, often strongly so and leaves bullate, petals $7-11 \mathrm{~mm}$ long, stiffly appressed pubescent outside 9. G. bullata

28b. Venation not impressed above or if impressed then petals subglabrous, leaflets not bullate, petals usually smaller 29

29a. Young shoots, sepals and outer surface of petals densely pilose-setose 51. G. donnell-smithii

29b. Young shoots, sepals and petals not pilose-setose 30

30a. Leaflets glabrous below 8. G. chiricana

30b. Leaflets pubescent below 31

31a. Finely reticulate higher order venation visible on both surfaces of the leaflet, petals usually glabrous

8. G. chiricana

31b. Reticulate higher order venation not conspicuous, petals pubescent or puberulous 32

32a. Petiole $10-13.5 \mathrm{~cm}$ long, leaves with a dormant inactive terminal bud, Mato Grosso, Brazil 14. G. zepivae

32b. Petiole 2-6 cm long, leaves with a terminal bud showing intermittent growth, Mexico to Honduras 33

33a. Calyx shallowly lobed or margin truncate, petals $4-6.5 \mathrm{~mm}$ long

6. G. glabra

33b. Calyx lobed for $1 / 3$ to $1 / 2$ its length, petals c. $8 \mathrm{~mm}$ long 60. G. mexicana

34a. Fruit with 12-16 thin convoluted and anastomosing longitudinal wings 5-10 $\mathrm{mm}$ deep 35

$34 \mathrm{~b}$. Fruit verrucose, ribbed or shallowly winged, the ribs sometimes torulose or tuberculate 36

35a. Young branches velutinous or tomentose, leaflets coriaceous, base obtuse or truncate, tertiary veins obscure, petals $7-10 \mathrm{~mm}$ long 25. G. velutina

35b. Young branches appressed puberulous, leaflets chartaceous, base narrowly attenuate, tertiary venation easily visible, petals c. $5.5 \mathrm{~mm}$ long

57. G. juglandiformis 
36a. Leaflets 5-6.5 cm long, c.2 times as long as broad, broadly oblanceolate, obovate or cuneiform, coriaceous, fruit c. $1.5 \mathrm{~cm}$ diam., tuberculate-ribbed 65. G. sphenophylla

36b. Leaflets larger, not obovate or cuneiform, if oblanceolate then at least 3 times as long as broad and chartaceous, fruit larger (except G. gracilis) 37

37a. Secondary veins $23-24$ pairs, anthers with a short terminal appendage, ovary 6-locular

58. G. lozanii

37b. Secondary veins not more than 16 pairs, anthers without a terminal appendage, ovary 4-5-locular 38

38a. Fruit contracted at the base into a stipe $0.5-0.8 \mathrm{~cm}$ long 39

$38 \mathrm{~b}$. Fruit without a stipe, or if present then only 1-2 mm long 40

39a. Leaves without intermittent apical growth, secondary veins 11-16 pairs, \pm straight and parallel, petals $9-13 \mathrm{~mm}$ long, valves of fruit with 3-5 shallow wrinkled ribs

55. G. humaitensis

39b. Leaves with intermittent apical growth, secondary veins 8-11 pairs, arcuate and convergent, petals 5.5-6.5 mm long, valves of fruit with 3 ribs or shallow wings, these sometimes anastomosing

26. G. costata

40a. Tertiary veins numerous, fine, parallel, oblique, ovary short, rounded at the apex, densely long-strigose, capsule depressed-globose or globose, obscurely ribbed and often minutely tuberculate between the ribs, usually coarsely pubescent

21. G. pubescens

40b. Tertiary venation not finely parallel and oblique, ovary tapering to the apex, pubescent or strigose, capsule obovoid, pyriform, globose or rarely depressedglobose, mostly puberulous 41

41a. Leaflets $23-42 \mathrm{~cm}$ long, inflorescence cauliflorous or ramiflorous on larger branches 30. G. blanchetii

41b. Leaflets generally much smaller, inflorescence axillary or in the axils of fallen leaves 42

42a. Secondary veins 5-7 pairs, petiolule $1.5-1.7 \mathrm{~cm}$ long 22. G. zarceroensis

42b. Secondary veins $6-14$ pairs, petiolule up to $10 \mathrm{~mm}$ long 43

43a. Fruit obscurely to prominently torulose or verrucose, if ribbed then ribs torulose or verrucose

28. G. macrophylla

43b. Fruit obscurely to prominently ribbed (ribs not torulose or verrucose) _ _ 44

44a. Lower leaflet surface uniformly softly pubescent, capsule broadly pyriform, valves shallowly 3-ribbed 29. G. pendula

44b. Lower leaflet surface with scattered hairs confined to the midrib, capsule depressed-globose, valves prominently 3-ribbed (ribs 2-3 $\mathrm{mm}$ high)

31. G. gracilis

45a. Leaf rhachis broadly winged

12. G. pterorhachis 
45b. Leaf rhachis unwinged 46

46a. Leaflets 32-39 cm long, young shoots and lower leaflet surface hispid with yellow hairs, venation brochidodromous, secondary veins 38-40 pairs

45. G. casimiriana

46b. Leaflets shorter, or if as long then indumentum not hispid, venation eucamptodromous and secondary veins fewer 47

47a. Fruit $9.5-10.5 \times 9-9.5 \mathrm{~cm}$, broadly pyriform, pericarp $0.8-1.2 \mathrm{~cm}$ thick, valves with 3 longitudinal rounded ribs, ribs branched and tuberculate towards the apex

53. G. grossa

47b. Fruit smaller, rarely up to $9 \mathrm{~cm}$ long, but then without prominent rounded ribs 48

48a. Ovary glabrous 49

48b. Ovary pubescent 52

49a. Leaf without a terminal bud, ovary 2-3(-4)-locular, capsule strongly constricted between the seeds, cotyledons collateral

1. G. silvatica

49b. Leaf with a terminal bud, ovary (3-)4-locular, capsule not or only slightly constricted between the seeds, cotyledons superposed 50

50a. Leaflets with hair tufts in the axils of the secondary veins below

56. G. inesiana

50b. Leaflets without hair tufts in the vein axils 51

51a. Twigs hollow, leaflets $30-50 \mathrm{~cm}$ long, petals glabrous

46. G. constricta

51b. Twigs not hollow, leaflets mostly $15-25 \mathrm{~cm}$ long, petals with appressed indumentum outside 10. G. kunthiana

52a. Leaves strongly bullate 53

52b. Leaves not bullate 54

53a. Secondary veins 18-23 pairs, inflorescence axillary or on twigs below the leaves, ovary 6-8-locular, fruit 3.5-4 cm long, obovoid

15. G. sprucei

53b. Secondary veins 23-26 pairs, inflorescence cauliflorous, ovary 4-locular, fruit c. $5 \mathrm{~cm}$ long, broadly oblong, tapering at the base to a stout stipe $\mathrm{c} .1 \mathrm{~cm}$ long 62. G. reticulatovenosa

54a. Venation brochidodromous, secondary veins 25-30 pairs 69. G. venenata

54b. Venation eucamptodromous, or if brochidodromous then secondary veins fewer than 20 pairs 55

55a. Leaflets broadly oblanceolate, obovate or cuneiform, 5-8.5 cm long, c.2 times as long as broad, coriaceous, inflorescence $2-3 \mathrm{~cm}$ long, 1-6-flowered _ 56

$55 \mathrm{~b}$. Not with the above combination of characters, leaflets larger or at least 3 times as long as broad, and inflorescence longer and with more flowers 57 
56b. Fruit tuberculate-ribbed 65. G. sphenophylla

57 a. Indumentum of young parts and lower lamina prominently villose, tomentose, hispid or coarsely pubescent 58

$57 \mathrm{~b}$. Indumentum of young parts finely and minutely puberulous, lower lamina sparsely and minutely puberulous or glabrous 70

58a. Fruit winged, ribbed or tuberculate 59

$58 \mathrm{~b}$. Fruit smooth 65

59a. Mature capsule with thin fleshy convoluted longitudinal wings _ 60

59b. Mature fruit ribbed or tuberculate _ـ 62

60a. Ovary 9-10-locular, valves of fruit with a single longitudinal wing

67. G. talamancana

60b. Ovary 4-8-locular, valves of fruit with several (usually at least 3) longitudinal wings 61

61a. Leaves bullate, indumentum of lower leaf surface sparse, confined to midrib and veins, ovary 6-8-locular, fruit 3-4 cm long

19. G. michel-moddei

61b. Leaves not bullate, lower leaflet surface coarsely and uniformly hirsute, ovary 4-6-locular, fruit 4-6 cm long 17. G. cristata

62a. Indumentum of lower lamina inconspicuous, shortly and finely pubescent, secondary veins mostly 6-14 pairs, mature fruit ribs tuberculate, ovary usually 4-locular, fruit not exceeding $3.5 \mathrm{~cm}$ long

28. G. macrophylla

$62 \mathrm{~b}$. Indumentum of lower lamina conspicuous, coarsely pubescent, hirsute or villose, secondary veins more numerous, mature fruit ribbed, not tuberculate, ovary 5- or 6-locular, fruit $3-4.8 \mathrm{~cm}$ long 63

63a. Inflorescence axillary or on twigs below the leaves, secondary veins (14-)16-20 pairs, petals 14-17 mm long, ovary (4-)5-6(-9)-locular

16. G. carinata

63b. Inflorescence cauliflorous, secondary veins $18-21$ pairs, petals $12-13 \mathrm{~mm}$ long, ovary 4-locular 64

64a. Leaflets oblanceolate, indumentum of young shoots and lower lamina hirsutevillose

52. G. eriorhachis

64b. Leaflets broadly oblong to elliptic, indumentum of young shoots and lower lamina puberulous to tomentose

13. G. caulobotrys

65a. Petals nearly always less than $10 \mathrm{~mm}$ long

28. G. macrophylla

65b. Petals $10-20 \mathrm{~mm}$ long 66

66a. All parts of shoot, leaves and inflorescence with dense golden tomentose indumentum, leaflets $30-66 \mathrm{~cm}$ long, secondary veins $25-33$ pairs, petals 18-20 mm long 33. G. ecuadoriensis

66b. Indumentum mostly pubescent or puberulous, if tomentose, then leaflets much smaller and secondary veins fewer than 20 pairs, petals $10-18 \mathrm{~mm}$ long 67 
67a. Lower lamina uniformly puberulous with pale whitish crisped hairs

68. G. trunciflora

67b. Lower lamina not puberulous with crisped whitish hairs, indumentum generally sparser, pubescent and often confined to midrib and veins 68

68a. Secondary veins 16-18 pairs, inflorescence racemose, ovary 4-locular, capsule 4-valved 20. G. subandina

68b. Secondary veins 11-14 pairs, if more then inflorescence paniculate, ovary (4-)7-10-locular, capsule 5-10-valved 69

69a. Twigs slender (3-5 mm diam.), upper lamina with numerous minute raised protuberances, inflorescence usually racemose, rarely a slender panicle, always cauliflorous, petals $15-18 \mathrm{~mm}$ long, anthers $2-2.2 \mathrm{~mm}$ long

54. G. hoffmanniana

69b. Twigs massive (more than $1 \mathrm{~cm}$ diam.), upper lamina without raised protuberances, inflorescence a panicle, petals (9-)10-14(-17) mm long, anthers 1.4 1.7(-2) $\mathrm{mm}$ long

42. G. grandifolia

70a. Fruit winged, ribbed or tuberculate 71

70b. Fruit smooth or only faintly lined (strongly constricted between the valves in G. aguilarii) 78

71a. Calyx lobes abruptly contracted into an acumen 1-2 mm long or into a slender subulate point 72

71b. Calyx lobes not abruptly contracted into an acumen or subulate point _ 73

72a. Twigs hollow, petals $1.5-1.7 \mathrm{~cm}$ long, capsule c. $6 \times 7 \mathrm{~cm}, 6-8$-valved, slightly tuberculate when dry

23. G. tafae-malekui

72b. Twigs not hollow, petals $8-14 \mathrm{~mm}$ long, capsule c. $2 \times 2 \mathrm{~cm}$, 4- or 5-valved, valves with 3 shallow longitudinal ribs, ribs tuberculate in the upper half

24. G. macrocalyx

73a. Twigs hollow, secondary veins $18-28$ pairs, fruit valves 3-winged (wings 2$4 \mathrm{~mm}$ deep) 34. G. fistulosa

73b. Twigs not hollow, secondary veins $12-16$, fruit ribbed or tuberculate 74

74a. Fruit tuberculate 28. G. macrophylla

74b. Fruit shallowly ribbed (ribs sometimes tuberculate) 75

75a. Dried leaves smell strongly of curry powder, fruit usually botuliform, tapering at the base into a stout stipe $\mathrm{c} .1 \mathrm{~cm}$ long, obscurely ribbed

27. G. guentheri

75b. Dried leaves not smelling of curry powder, fruit pyriform to ellipsoid, without a stipe 76

76a. Fruit $2-3 \mathrm{~cm}$ long 49. G. corticosa

76b. Fruit $4-8 \mathrm{~cm}$ long 77 
77a. Secondary veins 9-12 pairs, lower lamina puberulous to glabrous, capsule shallowly 12(-15)-ribbed, ribs sometimes torulose 63. G. rhopalocarpa

77b. Secondary veins $12-16$ pairs, lower lamina minutely sericeous at first, becoming glabrous, capsule with c.16 shallow corrugated ribs 48. G. corrugata

78a. Lower lamina moderately to densely puberulous or pubescent 79

78b. Lower lamina glabrous 81

79a. Indumentum of young shoots and inflorescence minutely papillose, capsule 3-4 cm long 61. G. polymera

$79 \mathrm{~b}$. Indumentum of young shoots and inflorescence puberulous to tomentose, capsule generally smaller 80

80a. Indumentum of lower lamina of minute crisped hairs, petals 15-17.5 mm long, ovary 4-6(-7)-locular

44. G. cartaguenya

$80 \mathrm{~b}$. Indumentum of lower lamina of straight puberulous hairs, petals (9-)1014(-17) mm long, ovary (4-)7-8(-10)-locular 42. G. grandifolia

81a. Ovary locules with (3-)4 superposed ovules, fruit c. $6 \times 7 \mathrm{~cm}$

23. G. tafae-malekui

81b. Ovary locules with 1-2 superposed ovules, fruit variable in size 82

82a. Fruit less than $2.5 \mathrm{~cm}$ long 28. G. macrophylla

82 b. Fruit $3-7(-8) \mathrm{cm}$ long 83

83a. Fruit strongly constricted between the valves 43. G. aguilarii

$83 \mathrm{~b}$. Fruit not constricted between the valves 84

84a. Ovary locules 9-12, petals c. $17 \mathrm{~mm}$ long, fruit c. $7.5 \mathrm{~cm}$ long, pyriform 32. G. carapoides

84b. Ovary locules $4-8$, petals $8-12 \mathrm{~cm}$ long, fruit usually $2.5-5.2 \mathrm{~cm}$ long, globose, botuliform, obovoid or pyriform 85

$85 \mathrm{a}$. Fruit globose to shortly pyriform, valves 1 -seeded 37. G. gomma 85 b. Fruit obovoid to shortly botuliform, valves 2 -seeded 39. G. purusana

1. Guarea silvatica C.DC. in Mart., Fl. Bras. 11(1): 195, t. 57 (1878); T.D.Penn. in T.D.Penn. et al., Fl. Neotrop. 28: 323, fig. 67 (1981). - Type: Brazil, Amazonas, 'in sylvis Japurensibus', fl., Martius s.n. (holo M). Fig. 48A.

For synonymy see T.D.Penn. in T.D.Penn. et al., Fl. Neotrop. 28 : 324 (1981).

Abbreviated description. Young shoots and inflorescences minutely puberulous or glabrous, leaves paripinnate without a terminal bud, leaflets $2-4(-6)$ pairs, $(6.5-) 10-$ $20(-32) \times(2.5-) 4-8(-13) \mathrm{cm}$, usually elliptic, less frequently lanceolate, oblanceolate or oblong-elliptic, chartaceous to thinly coriaceous, glabrous. Inflorescence axillary, or several on a short lateral shoot, $8-40(-125) \mathrm{cm}$ long, unbranched, flowers clustered along the axis in distant cymose fascicles, petals 4(-5), imbricate, 5-7.5(-10) $\mathrm{mm}$ long, staminal tube (4-)5-6(-8.5) $\mathrm{mm}$ long, 1.5-3 $\mathrm{mm}$ broad, anthers $(5-) 8(-10)$, 
ovary 2-3(-4)-locular, locules with 1-2 superposed ovules, capsule $3.8-5 \mathrm{~cm}$ long, 2.5-4 cm broad, constricted between the seeds, smooth, glabrous, 2(-3)-valved, pericarp 1.5-2 $\mathrm{mm}$ thick, valves 1-seeded. Seed coat bony, c. $1 \mathrm{~mm}$ thick, cotyledons collateral.

Distribution and ecology. Southern Venezuela and the Guianas, Amazonian Colombia, Ecuador and Peru, and Amazonian Brazil. Mostly a component of primary lowland rain forest on non-flooded land. Its ability to sucker from cut trunks enables it to persist in secondary regrowth, where it may flower as a small treelet.

Representative additional collections. Colombia. Caquetá: Solano, $8 \mathrm{~km}$ SE of Tres Esquinas (NW0075), Little \& Little 9702 (K).

Venezuela. Amazonas: San Carlos de Rio Negro (NW0167), H.L. Clark 7237 (K).

GuYana. Upper Takutu-Upper Essequibo Region, Acarai Mts. (NW0158), D. Clarke et al. $7577(\mathrm{~K})$.

Surinam. Tumuc Humac Mts., Talouakem (NW0254), Acevedo-Rodriguez et al. 5986 (K). French Guiana. Vicinity of Les Eaux Claires, $6 \mathrm{~km} \mathrm{NNW}$ of Saül (NW0353), N.P. Smith et al. $13(\mathrm{~K})$.

Ecuador. Morono-Santiago: 40 km NNE of Macas (SW0278), Pennington \& Tenorio 10797 (K). Napo: 8 km below Misahualli, Jatun Sacha (SW0177), Palacios \& Neill 958 (K). Orellana: Yasuní National Park, Maxus road km 8-10 (SW0076), Zuleta 128 (K). Zamora-Chinchipe: Quimi Valley (SW0378), van der Werff et al. 19177 (K).

Peru. Loreto: Maynas, R. Itaya, San Antonio (SW0373), Vásquez \& Jaramillo 3549 (K).

Brazil. Acre: Municipio Mal. Traumaturgo, Rio Alto Jurua, N of São João do Breu (SW0972), Silveira et al. 524 (K). Amazonas: Manaus, Ducke Reserve (SW0259), Assuncão et al. 328 (K). Pará: Marabá, Carajas (SW0549), Maciel et al. 799 (K).

The ITS phylogeny indicates that Guarea silvatica occupies a very isolated position at the end of a long, basally divergent branch. Morphologically it is anomalous in having leaves lacking the terminal bud, imbricate petals and seeds with a bony seed coat and embryo with collateral cotyledons. However, it retains the essential characters of the genus (stamens inserted within the throat of a complete staminal tube and the stipitate ovary with discoid style-head).

2. Guarea anomala T.D.Penn., sp. nov. [T.D.Penn., Bol. Técn. Centro Pesq. Cacau 143: 21, fig. 11 (1986), nom. inval. (in Portuguese)]. Figs 3, 51A.

A speciebus aliis foliolis alternis, uno foliolo paris ultimis ad instar folioli terminalis ordinato, inflorescentia minuta, floribus glabris, petalis 3-4, ovario 3-4-loculare distinguenda. - Type: Brazil, Bahía, Municipio de Ilheus, road between Sururu and Vila Brasil, 6-14 km from Sururu, 12-20 km SE of Buerarema [SW1439], $100 \mathrm{~m}$ altitude, fl., Mori \& Benton 12995 (holo CEPEC; iso K, NY, RB, US).

Young shoots slender, shortly pubescent at first, soon glabrous, becoming pale whitish, smooth or slightly scaling, without lenticels, 5-6 mm diam. Leaves pinnate with one leaflet orientated to simulate a terminal leaflet, petiole $2.8-6.1 \mathrm{~cm}$ long, slender, semiterete, glabrous, rhachis $7-11 \mathrm{~cm}$ long, terete; petiolule $0.7-1.2 \mathrm{~cm}$ long, pulvinate at the base, the pulvinus transversely corrugated, glabrous. Leaflets 5-6, 

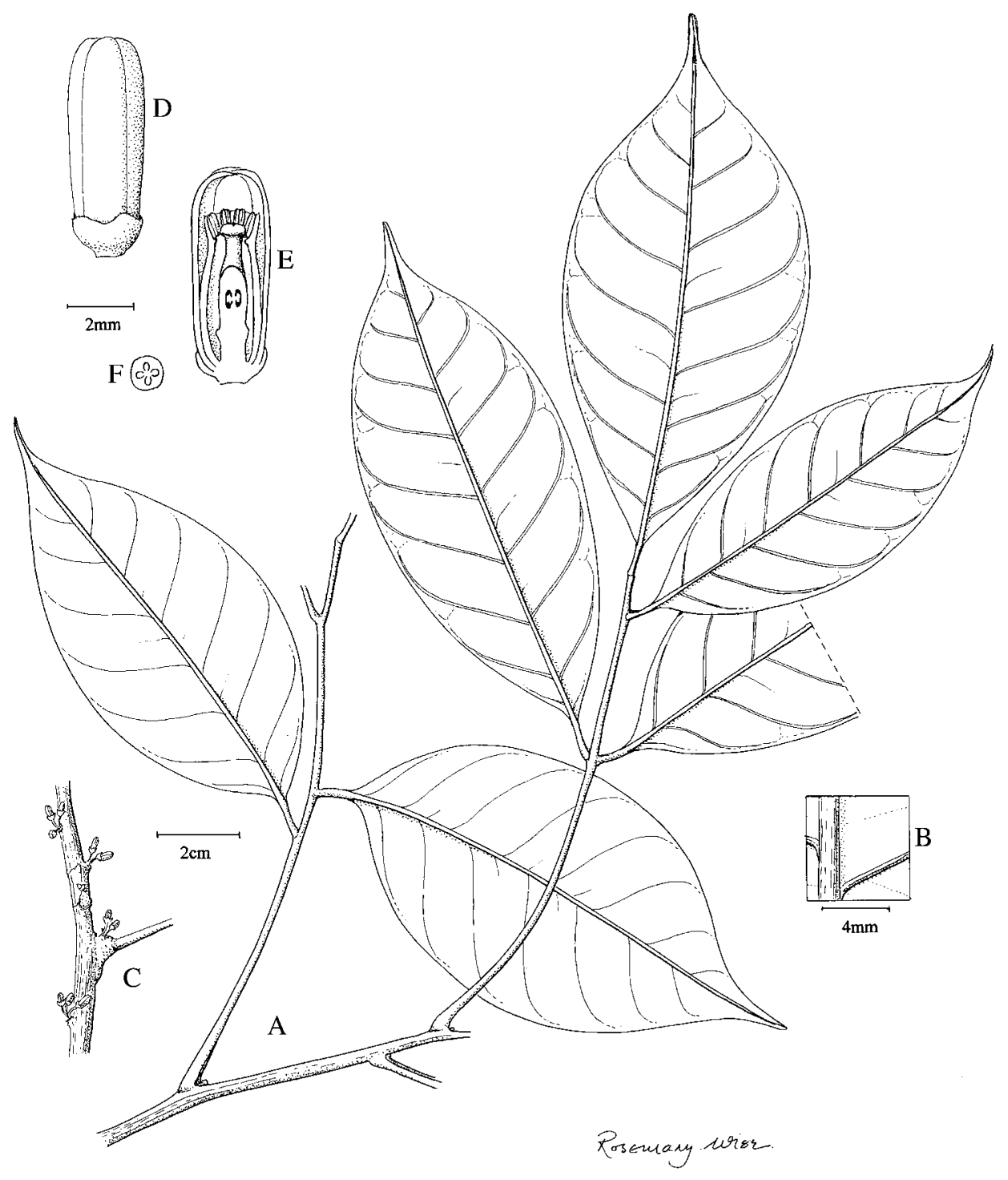

FIG. 3. Guarea anomala T.D.Penn. A, habit; B, enlargement of leaf undersurface; C, inflorescences; D, flower; E, half-flower; F, cross-section of ovary. (A-F, Mori \& Benton 12995).

alternate or rarely a few opposite, largest (uppermost) up to $17 \times 7.1 \mathrm{~cm}$, smallest (lowermost) c. $6.5 \times 4.1 \mathrm{~cm}$, elliptic, apex narrowly attenuate, thinly coriaceous, glabrous, not glandular-punctate or -striate; venation eucamptodromous, midrib slightly raised on the upper surface, secondaries 9-11 pairs, ascending, slightly arcuate, slightly convergent, intersecondaries moderately long, tertiaries obscure. Inflorescence axillary or on twigs below the leaves, c. $1 \mathrm{~cm}$ long, a few-flowered 
fascicle, indumentum of a few appressed hairs; pedicel c. $1 \mathrm{~mm}$ long. Calyx cupshaped, c.1 mm long, with 3-4 minute shallow teeth, glabrous. Petals 3-4, 6-7 mm long, c. $1.5 \mathrm{~mm}$ broad, strap-shaped, apex acute, aestivation valvate or slightly imbricate, glabrous. Staminal tube c. $5 \mathrm{~mm}$ long, c. $1.5 \mathrm{~mm}$ broad, margin undulate, glabrous; anthers 8, c.1 mm long, oblong, dehiscent, glabrous. Nectary c.1.5 mm long, a stout stipe expanded at the apex into a collar below the ovary, glabrous. Ovary 1.5-2 mm long, slender, 3-4-locular, locules with 1 ovule, glabrous, style c. $1 \mathrm{~mm}$ long, stout, glabrous, surmounted by a thick discoid stigma. Fruit unknown.

Field characters. Tree to $15 \mathrm{~m}$ high and $25 \mathrm{~cm}$ diam., with reddish flowers. Flowering recorded in November and April.

Distribution and ecology. Known only from Bahía, Brazil where it is a component of the southern Bahian wet forest around $100 \mathrm{~m}$ altitude.

Collections examined. BrazIL. Bahía: road Guaratinga to São Paulinho (SW1639), Pinheiro 2092 (CEPEC, K).

Local name. Cedro cabacinha.

Guarea anomala is a most distinctive species, unlike any other in the genus; indeed at first sight it appears to be a species of Trichilia. It has alternate leaflets, with the uppermost one orientated to simulate a terminal leaflet; it lacks the terminal bud characteristic of nearly all species in the genus; and the leaflets have a pulvinate, corrugated petiolule reminiscent of many legumes and lack higher order venation. The minute fasciculate inflorescence is also distinctive, as are the small flowers with 3-4 petals and 3-4-locular ovary. Of the 22 flowers studied, 9 have 3 petals and 13 have 4 petals.

The ITS phylogeny confirms its isolated position at the end of a long, basally divergent branch. Like Guarea silvatica it has retained the essential characters of the genus.

Note on species 3-9. These are all closely related members of the Guarea glabra complex, whose relationships are discussed in the Phylogenetics section above. There is little genetic or morphological variation between the component species, and their placement at the end of a long branch suggests an ancestral dispersal into Central America and a recent species radiation.

3. Guarea gentryi Coronado, Novon 16(4): 464 (2006). - Type: Costa Rica, Heredia, Finca la Selva, OTS Field Station, fl., Folsom 9404 (holo MO; iso CR, F). Figs 4, 52A.

Young shoots minutely appressed puberulous at first, soon glabrous, becoming greyish brown, smooth with a few large lenticels, 5-8 $\mathrm{mm}$ diam. Leaves pinnate with a terminal bud showing intermittent growth, petiole $4.5-7.5 \mathrm{~cm}$ long, semiterete, glabrous, rhachis $6.5-22 \mathrm{~cm}$ long, semiterete, glabrous; petiolule 5-12 mm long, minutely puberulous. Leaflets opposite, 2-3 pairs, uppermost $11.5-21.5 \times 7-9 \mathrm{~cm}$, 


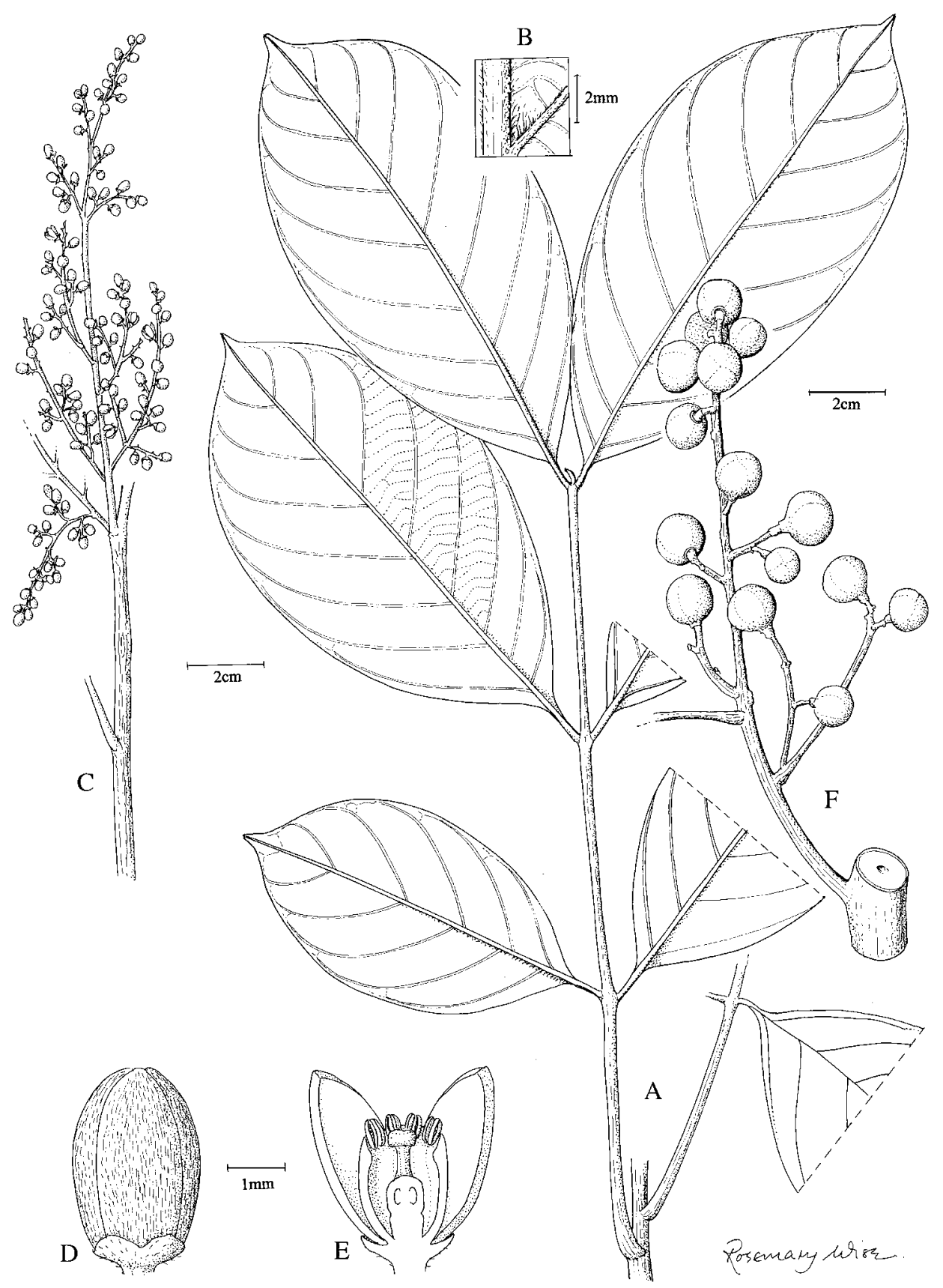

FIG. 4. Guarea gentryi Coronado. A, habit; B, enlargement of leaf undersurface; C, inflorescence; D, flower bud; E, half-flower; F, infructescence. (A-C, Fuchs \& Zanella 22361; D-F, Hammel et al. 17058). 
lowermost $8-14 \times 5-6.7 \mathrm{~cm}$, broadly elliptic to obovate or oblong-elliptic, apex shortly acuminate to obtusely cuspidate, base narrowly cuneate or attenuate to acute, coriaceous, upper surface glabrous, lower surface sparsely and minutely appressed puberulous, with scattered minute red papillae and small tufts of hairs in the axils of the secondary veins, not glandular-punctate or -striate; venation eucamptodromous, midrib slightly sunken on the upper surface, secondaries 8-10 pairs, ascending, slightly arcuate and slightly convergent, intersecondaries absent, tertiaries oblique, parallel; higher order venation obscure. Inflorescence axillary or on twigs below the leaves, 10-19 $\mathrm{cm}$ long, a profusely branched panicle, branches perpendicular to steeply ascending, the lower ones up to $10 \mathrm{~cm}$ long, minutely appressed puberulous, bracts c. $1 \mathrm{~mm}$ long, navicular, ovate; pedicel c. $1 \mathrm{~mm}$ long. Calyx patelliform, $0.5-0.75 \mathrm{~mm}$ long, with 4 shallow irregular lobes or teeth, appressed puberulous outside, glabrous inside. Petals 4(-5), 3-4 mm long, 1-1.5 mm broad, strap-shaped to lanceolate, apex acute, free, valvate, appressed puberulous outside, glabrous inside. Staminal tube c. $2.5 \mathrm{~mm}$ long, $1.5-2.5 \mathrm{~mm}$ broad, margin undulate, glabrous; anthers 8 , 0.6-0.8 mm long, oblong, dehiscent, glabrous. Nectary absent, but ovary on a short, stout stipe. Ovary $0.75-1 \mathrm{~mm}$ long, ellipsoid to ovoid, 4-locular, locules with 1 ovule, glabrous, style $0.5-0.75 \mathrm{~mm}$ long, style-head discoid. Fruit c. $2.5 \times 3 \mathrm{~cm}$, broadly pyriform, apex truncate, base cuneate to obtuse, 4-valved, valves 1-seeded, rather rough-skinned, glabrous, brown, pericarp 3-5 mm thick. Seed 1.5-2 cm long.

Field characters. Tree to $30 \mathrm{~m}$ high and $1 \mathrm{~m}$ diam., bark scaling in large patches, greyish, flowers greenish white. Flowering February to March in Colombia, recorded in March and June in Costa Rica and Nicaragua.

Distribution and ecology. In lowland rain forest below $500 \mathrm{~m}$ altitude, in Colombia (Choco), Panama, Costa Rica and Nicaragua.

Collections examined. Nicaragua. Zelaya: $60 \mathrm{~km} \mathrm{NW}$ of Puerto Cabezas, S of R. Wawa (NW1483), Little 25202 (MO); Kurinwacito (NW1384), Moreno 23640 (K, NY), 23685 (K), $23708(\mathrm{~K})$.

Costa Rica. Heredia: Braulio Carillo National Park, Magsasay Station (NW1084), Acevedo-Rodríguez et al. 150 (INB, K, MO), Gentry 71760A (K); Braulio Carillo National Park, El Ceibo Station (NW1084), Aguilar \& Hammel 35 (CR, MO); PN Braulio Carillo, Puesto el Ceibo (NW1084), Boyle 1394 (K), Boyle \& Ezeta 2800 (CR); Finca la Selva, OTS Station (NW1084), Hammel \& Trainer 12844 (F, MO, NY), Hartshorn 1408 (MO); PN Braulio Carillo, Magsasay (NW1085), Carballo 157 (INB, K); La Selva Rio Sarapiqui (NW1084), Gentry et al. 78629 (K). Limón: Canton de Talamanca, Amubri (NW0982), Hammel et al. 17515 (CR); Reserva Forestal Cordillera Volcanica Central (NW1083), Hammel et al. 17058 (F, K); Matina, PN Barbilla, Colonia Puriscalina (NW0983), Mora 906 (CR, INB).

Panama. Colon: Santa Rita (NW0979), Correa \& Dressler 735 (NY).

Colombia. Choco: area of Baudo, R. Baudo, $19 \mathrm{~km}$ upstream from estuary (NW0477), Fuchs \& Zanella 22361 (COL, G, K, NY, US).

Local name. Charde (Colombia) (possibly a corruption of Chalde which is used in Colombia for other Guarea species). 
This species is clearly closely related to Guarea glabra, sharing with it the hair tufts in the axils of the secondary veins and small 4-merous flowers with glabrous ovary. It differs in the minute whitish appressed indumentum on the lower leaflet surface, in the profusely branched inflorescence and very small flowers. The leaves dry brown on both surfaces.

The Colombian specimens were recognised as a new species (on herbarium sheets) many years ago, but only recently was complete material obtained from Costa Rica.

4. Guarea bijuga C.DC. in A.DC. \& C.DC., Monogr. Phan. 1: 567 (1878). - Type: Guatemala, without exact locality, fl., Skinner s.n. (holo K). Figs 5, 57A.

Guarea erythrocarpa C.DC., Bull. Herb. Boissier, Sér. 2, 5: 420 (1905). - Type: Costa Rica, Cartago, Tucurrique, fl., fr., Tonduz \& Pittier 13112 (holo G; iso BM, CR, F, G, GH, K, M, US, W, photo NY).

Guarea cook-griggsii C.DC., Smithsonian Misc. Collect. 68(6): 2 (1917). - Type: Guatemala, Alta Verapaz, near Finca Sepacuite, fl., Cook \& Griggs 408 (holo US; photo NY).

Guarea matudai Lundell, Lloydia 2: 93 (1939). - Type: Mexico, Chiapas, Mt. Tacana, fl., Matuda 2449 (holo MICH n.v.; iso A, F, K, MEXU, NY, US).

Guarea glabra auct. non Vahl: T.D.Penn. in T.D.Penn. et al., Fl. Neotrop. 28: 268 (1981), p.p.

Young shoots 4-6 mm diam., puberulous at first, soon becoming glabrous, greyish buff, smooth, with some large lenticels. Leaves pinnate with an active terminal bud, petiole 4-9(-14) cm long, semiterete at first, becoming terete with age, glabrous, rhachis 4-25 cm long, semiterete to slightly channelled, glabrous; petiolule stout, 5-10 mm long, glabrous. Leaflets opposite, up to 4 pairs, $(10.3-) 15-25(-38) \times$ $(4.2-) 6.7-10(-12) \mathrm{cm}$, broadly elliptic or oblong-elliptic, apex acuminate to obtusely cuspidate, base obtuse, narrowly cuneate, acute or narrowly attenuate, thinly coriaceous, glabrous, drying pale green, not glandular-punctate or -striate; venation eucamptodromous, midrib slightly sunken on the upper surface, secondaries (6-)711(-12) pairs, steeply ascending, straight or slightly arcuate, parallel to slightly convergent, intersecondaries short or absent, tertiaries oblique, parallel. Inflorescence axillary or on small twigs below the leaves, 4-15 cm long, a raceme or narrow thyrse, unbranched or with short lateral branches to $3 \mathrm{~cm}$ long, glabrous; pedicel 2-4 mm long, glabrous. Flowers unisexual (plant dioecious). Calyx (1-)2-3 mm long, patelliform or shallowly cup-shaped with 4 shallow to deep lobes, glabrous. Petals 4 , male $(6.5-) 7-10 \times 1.5-2.5 \mathrm{~mm}$, female 6-7.5 $\times 1.5-2 \mathrm{~mm}$, strap-shaped, apex acute, free, valvate, glabrous. Staminal tube (male) 5-8 $52-3 \mathrm{~mm}$, female 5-6 5 2-3 mm, broadly tubular, margin truncate or slightly undulate, glabrous; anthers $8(-9)$, 0.8-1 mm long, oblong, antherodes in female similar but not dehiscent. Nectary $0.5-1.5 \mathrm{~mm}$ long, a stout stipe slightly expanded into a collar at the base of the ovary. Ovary c. $2 \mathrm{~mm}$ long, ovoid, 4-locular, locules 1-ovulate, glabrous, male with rudimentary ovules, style 3-5 mm long, glabrous, style-head discoid. Capsule $1.3-3 \times 1.3-3 \mathrm{~cm}$, 


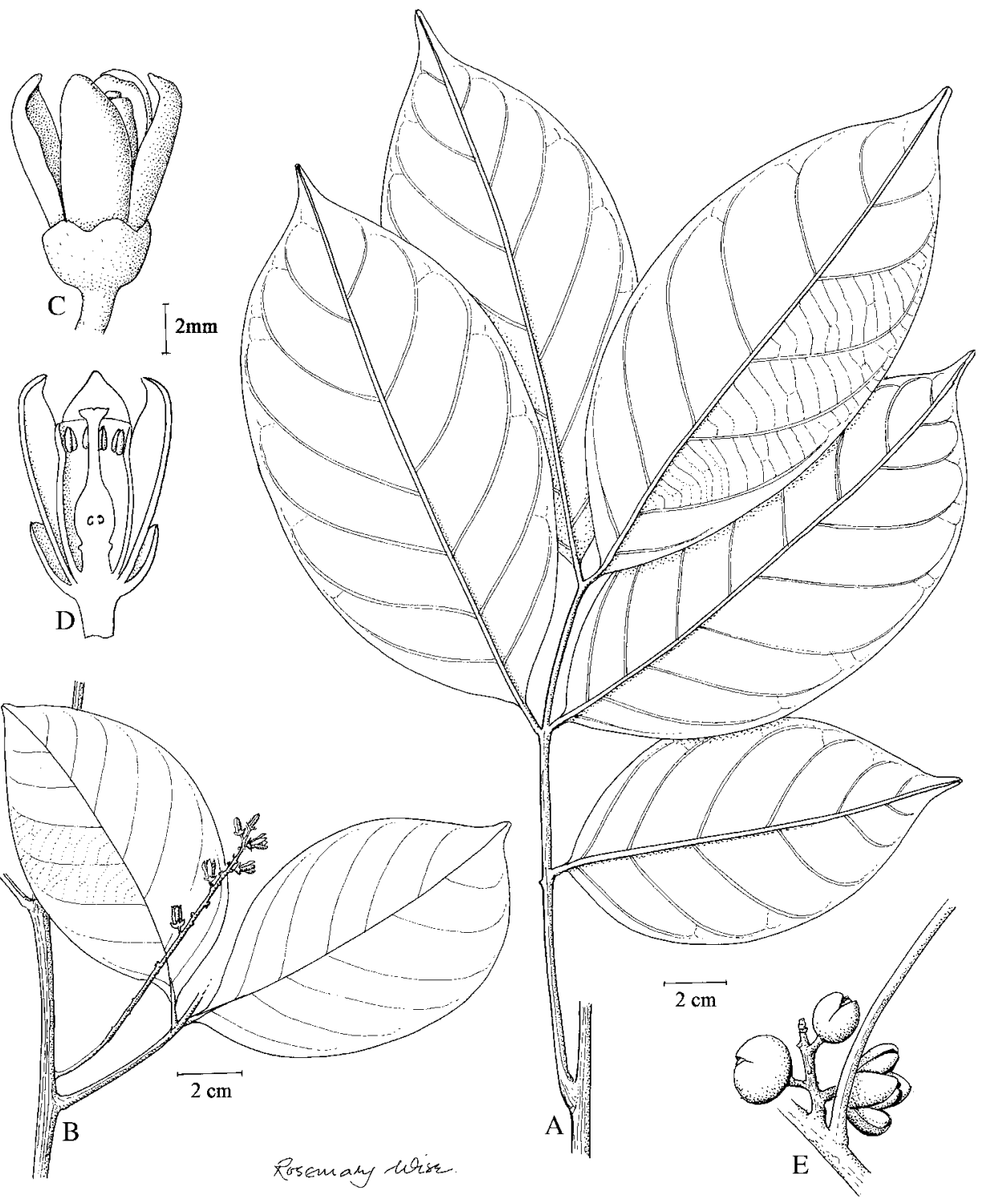

FIG. 5. Guarea bijuga C.DC. A, leaf; B, inflorescence; C, flower; D, half-flower; E, infructescence. (A, Hawkins 1221; B-D, Bello 4621; E, Marshall et al. 418).

globose, apex and base obtuse to truncate, often slightly lobed when dry and constricted between the seeds, (3-)4-valved, pericarp c.1 mm thick, fleshy, rough-skinned and rather warty with numerous pale lenticels, glabrous. Seeds 2-4, 1-2.5 cm long, shaped like the segment of an orange or banana-shaped; embryo with thick plano-convex, superposed cotyledons, radicle abaxial, extending to the surface. 
Field characters. Tree to $25 \mathrm{~m}$ high and $80 \mathrm{~cm}$ diam., but often flowering when less than $10 \mathrm{~m}$ high. Bark pale brown, slightly scaling or fissured, slash fragrant. Flowers creamish-white, sometimes tinged with pink, mature fruit red, containing 2-4 seeds completely surrounded by a bright red sarcotesta. In Mexico flowering is recorded from March to July, with fruit maturing during the same period. From Guatemala to Nicaragua flowering is from November to February with the fruit maturing in April, and from Costa Rica southwards to Ecuador the flowering is from January to March, with ripe fruit recorded from April to October.

Distribution and ecology. Caribbean drainage of Veracruz and Tabasco, Mexico to Panama and the Pacific coast of Ecuador; not recorded from El Salvador. It is a tree of wet lowland rain forest, wet montane forest and cloud forest with an altitudinal range from sea level to $2700 \mathrm{~m}$.

Representative additional collections. Mexico. Chiapas: Escuintla, Mt. Ovando (NW1592), Matuda 4168 (F, K, NY); Estación Biol. Chajul (NW1690), Dominguez Vásquez 666 (MEXU). Tabasco: Cerro de Campanas, E of Teapa (NW1792), Conrad \& Gallegos 2856 (MO, NY). Veracruz: Bastonal-Sierra Santa Marta road, c.14 km E of Lake Catemaco (NW1895), Gentry et al. $32450(\mathrm{~K})$.

Guatemala. Alta Verapaz: between Chajmayle and Sebol (NW1589), Steyermark 45739 (F). Izabal: Santo Tomas de Castilla (NW1588), Marshall et al. 418 (K). Petén: Seamay (NW1689), Contreras 6675 (NY). Quiche: Nebaj (NW1590), Skutch 1685 (NY, US). San Marcos: Volcan Tacana, between Canjula and La Union Juarez (NW1592), Steyermark 36502 (F).

Belize. Cayo: above Raspaculo R. (NW1688), Hawkins 1221 (K). Toledo: southern Maya Mountains, Bladen Nature Reserve (NW1688), Davidse \& Holland 36665 (K, MO).

Honduras. Atlantida: Tela, Lancetilla (NW1587), McDougal et al. 3314 (K). Yoro: Rio Guan Guan (NW1587), Hawkins \& Merello 823 (K).

Nicaragua. Chontales: 4 km NNW of Cuapa, Cerro Oluma (NW1285), Nee 28406 (K). Zelaya: Cano Montecristo, Las Benitas (NW1183), Moreno 15008 (K).

Costa Rica. Alajuela: Monteverde Reserve, Rio Penas Blancas (NW1084), Haber 811 (K).

Cartago: Turrialba, Tayutic, Grano de Oro (NW0983), Cascante 642 (CR, K). Guanacaste: Canton de la Cruz, Parque Nacional Guanacaste, Estación Maritza (NW1085), Espinoza 223 (K). Heredia: Sarapiqui, Puerto Viejo, Finca la Selva (NW1084), Hartshorn 1450 (F). Puntarenas: Canton de Osa, Rio Piedras Blancas (NW0883), Aguilar et al. 2259 (K).

Panama. Bocas del Toro: vicinity of Fortuna Dam (NW0882), McPherson 9725 (K). Veraguas: 5 miles W of Santa Fe (NW0881), Liesner 893 (MO).

Ecuador. Esmeraldas: Eloy Alfaro, Mayronga (NW0079), Pennington et al. 14080 (K, QCNE). Los Ríos: Cerro Samana, Hacienda Clementina (SW0179), Stahl 6701 (K).

This species differs from Guarea glabra in its broader leaflets which lack the hair tufts in the axils of the secondary veins. Apart from a little indumentum on the youngest shoots, the plant is completely glabrous. In Central America where its range overlaps that of Guarea glabra, it also differs in having a slightly longer, shallowly cup-shaped calyx and in its slightly longer petals. However, in the Lesser Antilles Guarea glabra is morphologically almost identical with G. bijuga, the only difference being the presence of hair tufts in the vein axils of G. glabra. Another characteristic of Guarea bijuga is the tendency of the persistent calyx in specimens 
with young fruit to develop a pale and slightly thickened margin. The leaves of Guarea bijuga nearly always dry pale green.

5. Guarea luxii C.DC. in J.D.Smith, Bot. Gaz. (Crawfordsville) 19: 2 (1894). - Type: Guatemala, Dept. Santa Rosa, Santa Rosa [NW1490], fl., Heyde \& Lux 3276 (holo G; iso BM, G, K, photo NY). Figs 6, 57B.

Guarea glabra auct. non Vahl: T.D.Penn. in T.D.Penn. et al., Fl. Neotrop. 28: 268 (1981), p.p.

Young shoots slender, 2-4 mm diam., finely puberulous at first, soon becoming glabrous, greyish white, smooth, with a few lenticels. Leaves pinnate with an active terminal bud, petiole $2-3.5 \mathrm{~cm}$ long, semiterete, sparsely appressed puberulous to glabrous, rhachis $2-16 \mathrm{~cm}$ long, semiterete, minutely puberulous to glabrous; petiolule 2-3 mm long. Leaflets opposite, up to 6 pairs, $(5.6-) 8-11.3(-14.5) \times(1.5-) 2.5-$ $3.6(-4) \mathrm{cm}$, narrowly elliptic or oblanceolate, apex acuminate, base narrowly attenuate or cuneate, chartaceous, glabrous, drying green, sometimes slightly glandular-striate; venation eucamptodromous in the lower half, brochidodromous in the upper half, midrib sunken on the upper surface, secondaries 12-18 pairs, shallowly ascending, slightly arcuate and slightly convergent, intersecondaries usually frequent and extending to near the margin; higher order venation laxly reticulate. Inflorescence an axillary thyrse, 2-11 cm long, usually few-flowered, lower branches up to $3 \mathrm{~cm}$ long, sparsely puberulous; pedicel 2-4 mm long, puberulous. Calyx c. $1 \mathrm{~mm}$ long, patelliform with 4 shallow acute to obtuse lobes, sparsely appressed puberulous outside, glabrous inside. Petals 4, male 5-6 × 1.5-2 mm, female $4.5 \times 2 \mathrm{~mm}$, strap-shaped, apex acute, free, valvate, with scattered minute appressed hairs outside, glabrous inside. Staminal tube (male) $44.5 \times 1.5-2 \mathrm{~mm}$, female $3.5 \times 1.5 \mathrm{~mm}$, tubular, margin undulate, glabrous; anthers 8, c. $0.8 \mathrm{~mm}$ long, oblong, glabrous, antherodes in female similar but not dehiscent. Nectary c. $1.5 \mathrm{~mm}$ long, a stipe slightly expanded into a collar below the ovary, shorter and unexpanded in the female. Ovary c. $1.5 \mathrm{~mm}$ long, ovoid, 4-locular, locules 1-ovulate, glabrous, male with rudimentary ovules, style $1.5-2 \mathrm{~mm}$ long, glabrous, stylehead discoid. Capsule 1.2-2.5 $\times 1.7-2.7 \mathrm{~cm}$, obovoid to globose, apex rounded to truncate, base obtuse to truncate, often slightly lobed when dry and constricted between the seeds, (3-)4-valved, pericarp 0.5-1 mm thick, smooth, glabrous, sometimes lenticellate. Seeds 2-4, 1-2 cm long, shaped like the segment of an orange; embryo with thick plano-convex, superposed cotyledons, radicle abaxial, extending to the surface.

Field characters. Treelet 3-10 m high with whitish or cream flowers and reddish brown capsules; the seed is surrounded by a bright red or orange sarcotesta. Flowering has been recorded in January, March, May and August and mature fruit in January, February, April and June.

Distribution and ecology. Mexico (Chiapas), Guatemala and El Salvador, in cloud forest, with all collections between $1800 \mathrm{~m}$ and $2600 \mathrm{~m}$ altitude (except for the type collection Heyde \& Lux 3276 which is annotated $3000 \mathrm{ft}$ (c.900 m)). 


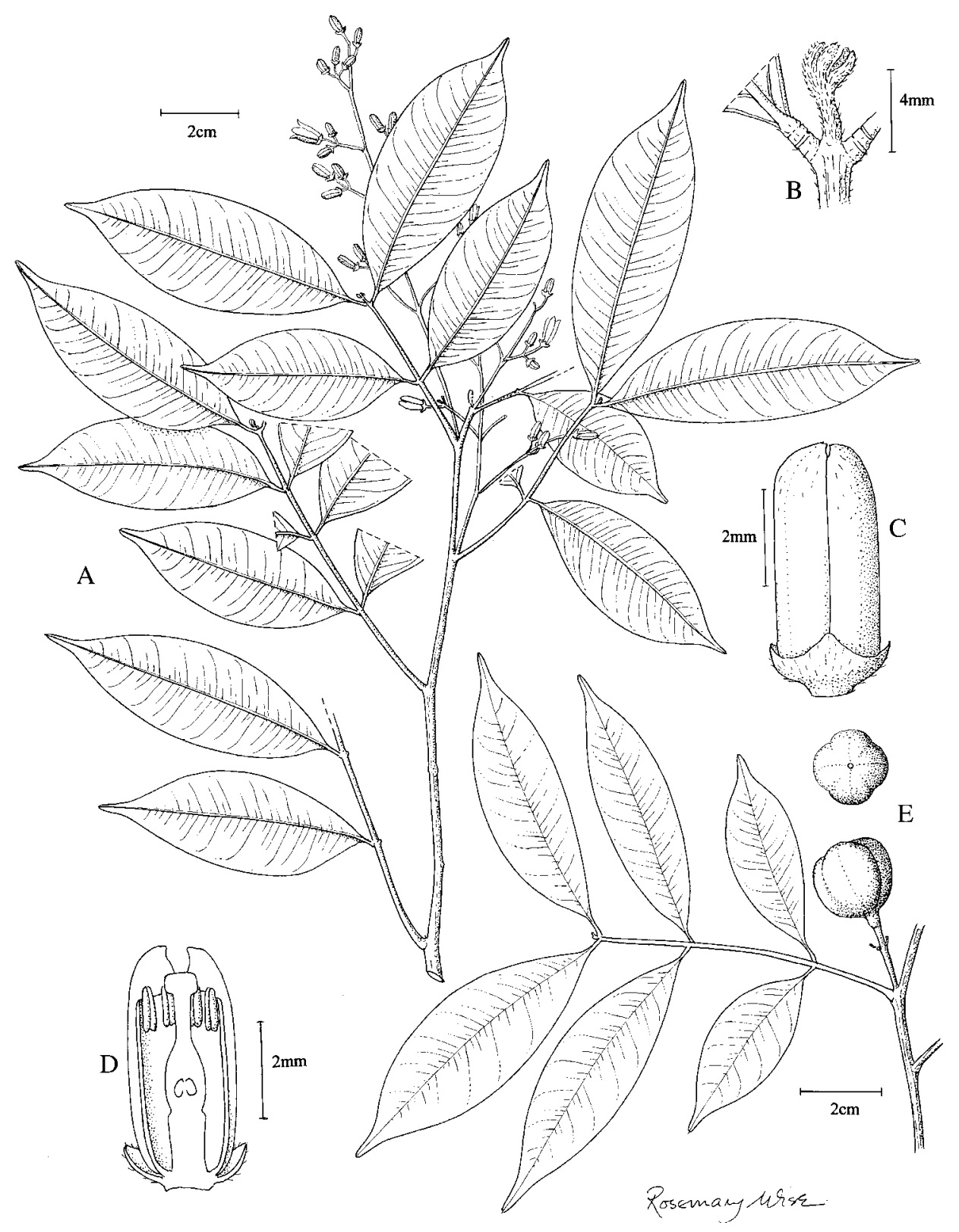

Fig. 6. Guarea luxii C.DC. A, habit; B, dormant bud at leaf apex; C, flower bud; D, halfflower; E, fruit. (A-D, Martinez s.n.; E, Villacorta \& Lara 2650).

Collections examined. Mexico. Chiapas: Escuintla, Santa Rosa (NW1490), Matuda 18660 (MEXU); Municipio La Concordia, El Triunfo Reserve (NW1592), Hampshire et al. 721 (G).

Guatemala. Quetzaltenango: above Mujalia, between San Martín Chile Verde and Colomba (NW1491), Standley 84898 (F); El Pocito, S of San Martín Chile Verde (NW1491), Standley 85046 (F). 
El Salvador. Santa Ana: Santa Ana, Montecristo National Park, Cordillera de Metapán (NW1489), Davidse et al. 37299 (K, MO); San José, Ingenio, Montecristo National Park (NW1489), Martínez s.n. (MO); Montecristo (NW1489), Molina \& Molina 12634 (F, US), 12646 (F, NY); Cordillera Miramundo (NW1489), Molina et al. 16910 (NY); Cerro Miramundo, Montecristo National Park (NW1489), Monterrosa 186 (K, MO); Montecristo cloud forest (NW1489), Reyna 1454 (K); Miramundito, Montecristo National Park (NW1489), Villacorta \& Lara 2650 (K, MO).

This species was treated as an informal ecological race of Guarea glabra in Flora Neotropica (Pennington et al., 1981), but the recent availability of additional fertile material enables it to be restored here to species rank, a move supported by a recent unpublished numerical study (Coronado, 2003). It is very similar to Guarea glabra subsp. excelsa, but differs in the small slender leaflets with more numerous secondary veins, and it lacks the characteristic hair tufts in the vein axils. The species are identical in floral and fruit structure. Guarea luxii is confined to high altitude cloud forest, whereas G. glabra subsp. excelsa is a tree of tropical deciduous forest at low elevations.

6. Guarea glabra Vahl, Eclog. Amer. 3: 8 (1807); T.D.Penn. in T.D.Penn. et al., Fl. Neotrop. 28: 268 (1981). - Type: St. Croix, Montserrat, fl., Ryan s.n. (holo C).

Guarea ramiflora Vent., Mem. Cl. Sci. Math. Inst. Natl. France 1: 20 (1807); Vent., Choix Pl. t. 41 (1807). - Type: Puerto Rico, fl., Collector not cited (ex herb. Ventenat) s.n. (holo G).

Guarea swartzii DC., Prod. 1: 624 (1824). - Type: Without definite locality, Forsyth s.n. (lecto G-DC, designated by C. de Candolle, Monogr. Phan. 1: 563 (1878)).

Guarea humilis Bert. ex DC., Prod. 1: 624 (1824). - Type: Puerto Rico, fl., Bertero s.n. (holo G-DC; iso MO).

Guarea vahliana A.Juss., Bull. Sci. Nat. Géol. 23: 239 (1830); A.Juss., Mém. Mus. Hist. Nat. 19: 240, 282 (1831). - Type: Guadeloupe, fl., Perrotet s.n. (holo P).

Guarea schomburgkii C.DC. in A.DC. \& C.DC., Monogr. Phan. 1: 565 (1878). - Type: Guyana, Schomburgk 779 (lecto G-DC, designated by Pennington in Pennington et al. (1981: 268); isolecto G, K, NY, P).

Guarea pauciflora Sessé \& Moc., Fl. Mexic. 100 (1894); Sessé \& Moc., Fl. Mexic., ed. 2, 92 (1894). - Type: Puerto Rico, mountains of Toa Alta, fl., Sessé s.n. (5117 in MA) (holo MA).

Guarea lherminieri C.DC., Bull. Herb. Boissier 2: 571 (1894). - Type: Guadeloupe, fl., Lherminier s.n. (holo G).

Guarea syringoides C.H.Wright, Bull. Misc. Inform. Kew 1906: 3 (1906). - Type: Ecuador, Manabi, El Recreo, fl., Eggers 15602 (lecto K, designated by Pennington in Pennington et al. (1981: 269); isolecto BM, C, F, M, S, US).

Guarea ternifoliola C.DC., Smithsonian Misc. Collect. 68: 2 (1917). - Type: Panama, Chiriqui, Remedios, fl., Pittier 5466 (holo US; iso G (fragment), GH, NY).

Guarea obtusata Blake, Proc. Biol. Soc. Washington 33: 118 (1920). - Type: Mexico, Oaxaca, Cerro Espino, Cafetal Concordia, fl., Reko 3701 (holo US; iso MEXU). This plant is intermediate with Guarea glabra subsp. excelsa. 
Guarea microcalyx Harms, Notizbl. Bot. Gart. Berlin-Dahlem 9: 429 (1925). - Type:

Ecuador, Manabi, El Recreo, fl., Eggers 15602 (holo B, destroyed; lecto BM, designated here; isolecto $\mathrm{C}, \mathrm{F}, \mathrm{M}, \mathrm{P}, \mathrm{S})$.

Guarea ciliata Al.Rodr., Lankesteriana 6: 105 (2006), syn. nov. - Type: Costa Rica, Heredia, La Virgen, La Selva Biological Station, fr., Rodríguez 8400 (holo INB; iso $\mathrm{CR}$ ).

Young shoots 3-5 mm diam., appressed puberulous at first, soon glabrous, becoming pale greyish-buff, smooth, with some raised lenticels. Leaves pinnate with an active terminal bud, petiole $2-6 \mathrm{~cm}$ long, semiterete, appressed puberulous at first, soon glabrous, rhachis up to $30(-50) \mathrm{cm}$ long, semiterete to terete, appressed puberulous at first, becoming glabrous and later woody with age; petiolule 2-6 mm long, subglabrous. Leaflets opposite, up to 8 pairs, $(6.5-) 10-16(-25) \times(2.5-) 3-$ $6(-9.5) \mathrm{cm}$, usually narrowly to broadly elliptic or oblanceolate, occasionally oblongelliptic, apex acuminate to obtuse or obtusely cuspidate, occasionally rounded, base narrowly attenuate, cuneate or acute, chartaceous to thinly coriaceous with tufts of hair in the axils of the secondary veins on the lower surface, otherwise glabrous (subspp. glabra, excelsa, microcarpa, tuerckheimii) or with some pubescence below (subspp. glabrescens, rovirosae), often obscurely glandular-punctate and -striate; venation eucamptodromous, midrib flat or slightly sunken on the upper surface, secondaries 6-10(-16) pairs, ascending, moderately to strongly arcuate, convergent, intersecondaries usually absent, tertiaries perpendicular to oblique, sometimes close and parallel, and sometimes reticulate. Inflorescence axillary, or sometimes on older wood below the leaves, (1-)5-15(-25) cm long, a panicle with short lateral branches usually not more than $5 \mathrm{~cm}$ long, ultimate branches racemose or cymose, sparsely appressed puberulous to subglabrous; pedicel 1-3 $\mathrm{mm}$ long, sparsely appressed puberulous to glabrous. Calyx $0.75-2(-2.5) \mathrm{mm}$ long, patelliform to shallowly cupshaped, margin usually shallowly 4-lobed, occasionally truncate, with sparse indumentum or glabrous outside, glabrous inside. Petals 4(-5), 4-9 $\times 1.5-2.5 \mathrm{~mm}$ long (see note below on dimensions of male and female flowers), strap-shaped, apex acute, sparsely appressed pubescent to glabrous outside, glabrous inside. Staminal tube 2.5$7.5 \times 1.5-3 \mathrm{~mm}$, broadly tubular to \pm globose, margin undulate or shallowly toothed, nearly always glabrous, rarely with sparse appressed hairs outside; anthers (7-)8(-10), 0.75-1 mm long, oblong, glabrous, antherodes in female similar but without pollen and not dehiscing. Nectary $0.5-2 \mathrm{~mm}$ long, a stipe expanded into a collar below the ovary, glabrous, in female shorter and unexpanded. Ovary 1-2.5 mm long, ovoid, 4(-5)-locular, locules 1-ovulate, glabrous, male with rudimentary ovules, style 1-2 mm long, glabrous, style-head discoid. Capsule (1-)1.4-2.5(-3) $\times(1.4-) 1.6-2.5(-3) \mathrm{cm}$, usually broader than long, \pm globose, apex rounded to truncate, base obtuse, rounded or truncate, (3-)4-valved, pericarp 1-2 mm thick, smooth to rough and densely scurfy, glabrous. Seeds up to 4, (0.8-)1.2-2.2 cm long, shaped like the segment of an orange; embryo with thick plano-convex, superposed to oblique cotyledons, radicle abaxial, included or extending to the surface. 
Note. Guarea ciliata Al.Rodr. is morphologically very similar to G. ternifoliola C.DC. (also a synonym of Guarea glabra subsp. glabra), with the same floral and fruit structure as typical G. glabra, but with the rather slender leaflets drying pale green, and with the axillary hair tufts reduced to a few hairs or absent. The young leaves on some specimens have a ciliate margin, but the mature leaflets are glabrous.

At any particular locality, there may be significant differences in the size of male and female flowers of this species, generally with the male flower having petals and staminal tube 1-2 $\mathrm{mm}$ longer than the female. However, across the range of the species these differences become obscured. Mexican material of the species is smallflowered, with the petals of both sexes not exceeding 4-6 mm long, but in Central America the flowers are larger, and the petals of female flowers from Guatemala, Nicaragua and Costa Rica are of equal length to or longer than those of male flowers from Mexico.

Field characters. Tree to $25 \mathrm{~m}$ high and $45 \mathrm{~cm}$ diam., often flowering when less than $10 \mathrm{~m}$ high, bark shallowly fissured or scaling, grey to grey-brown. The species is evergreen, even where it occurs in tropical deciduous forest. The flowers are white or whitish-green and fragrant, and the fruit matures from brown, through red to reddish purple. The inner face of the pericarp is white which contrasts with the bright reddish or orange sarcotesta which surrounds the seed. Flowering in the strongly seasonal climate along the Pacific drainage of Mexico and Central America occurs at the end of the dry season and beginning of the wet season from March to July, with the fruit maturing in the middle of the following dry season (February to March). In wet forest throughout the rest of its range, flowering has been recorded throughout the year.

Distribution. Mexico and Central America to northern South America, Pacific drainage of Ecuador, Amazonian Brazil south to Peru and Bolivia, Greater Antilles (Jamaica, Hispaniola and Puerto Rico), Lesser Antilles (Leeward and Windward Is.).

\section{6a. Guarea glabra subsp. glabra. Figs 7, 62.}

Young shoots and inflorescences appressed puberulous to glabrous, leaves glabrous (except for hair tufts), leaflets mostly elliptic, apex acute to acuminate, secondary veins mostly 6-10 pairs, arcuate, tertiary veins oblique, leaves drying green, petals mostly 5.5-8 mm long, glabrous, ovary glabrous.

Distribution and ecology. Same range as the species, except not yet recorded from Honduras, Belize and French Guiana. A tree of lowland and montane rain forest with a wide altitudinal range from near sea level to $1800 \mathrm{~m}$. Occasionally found in drier areas, but then confined to damp ravines and water courses. In El Salvador it is confined to cloud forest at $800-1800 \mathrm{~m}$ altitude. Along the Amazonian flank of the Andes its altitudinal range is from $200 \mathrm{~m}$ to $600 \mathrm{~m}$, in Jamaica up to $1500 \mathrm{~m}$.

Representative additional collections. Mexico. Oaxaca: Distrito Ixtlan, Rio Soyolapan watershed (NW1796), Boyle et al. 3896 (K). 


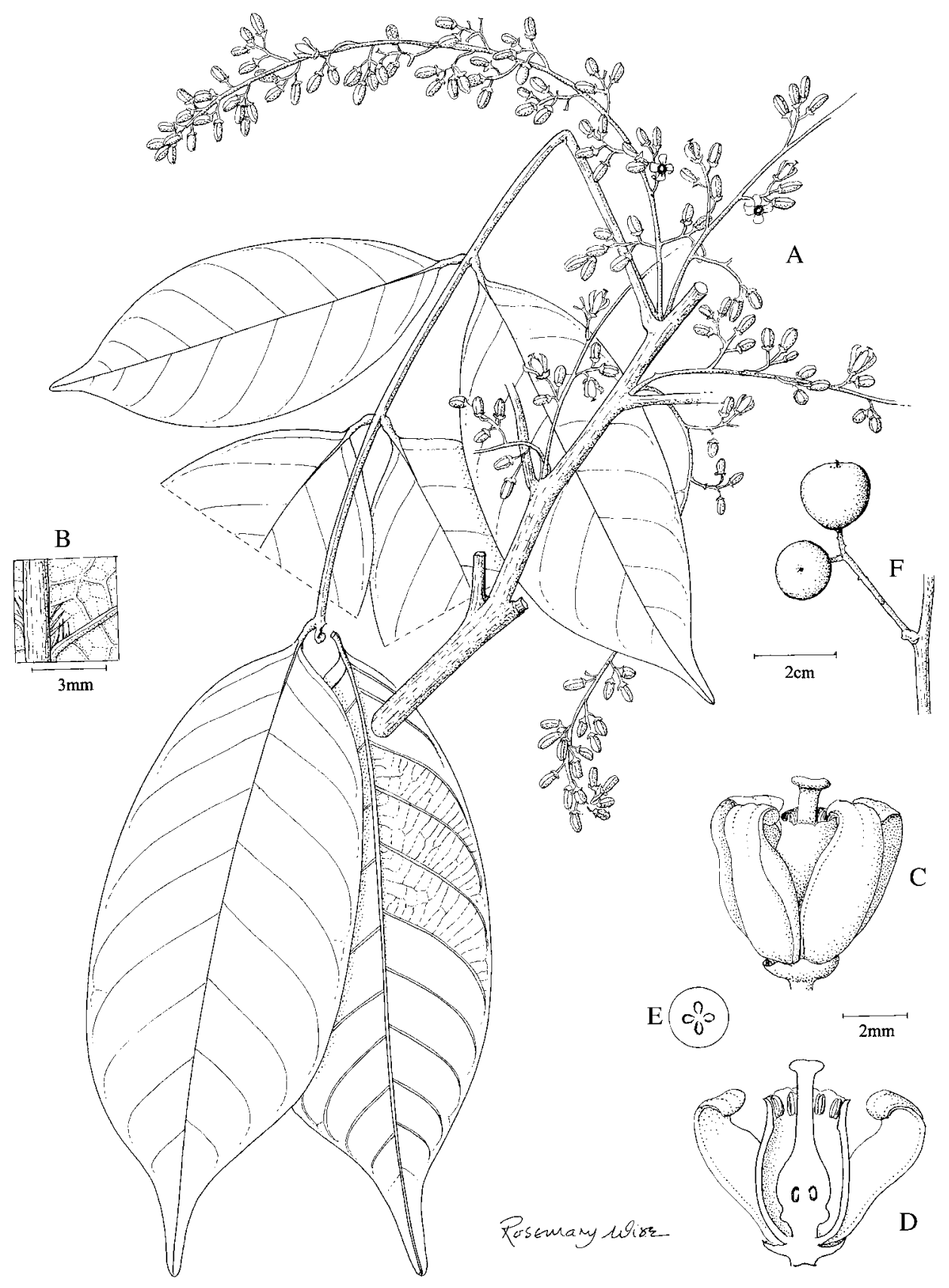

FIG. 7. Guarea glabra Vahl subsp. glabra. A, habit; B, enlargement of leaf undersurface; C, flower; D, half-flower; E, cross-section of ovary; F, fruit. (A-E, $L B B 16283 ; \mathrm{F}, B W 6677$ ). 
Guatemala. Baja Verapaz: Niño Perdido, San José (NW1590), Lundell \& Contreras 21141 (MO, NY). Sacatepequez: SE of Alotenango, near Barranco Hondo (NW1490), Standley 64991 (F). Solola: between Patulul and San Lucas Toliman (NW1491), Forther 10257 (W).

El Salvador. Ahuachapan: Municipio San Francisco Menendez, Cerro Davila (NW1389), Sandoval \& Chinchilla 10 (K, MO). La Libertad: Laderas Sur del Plan de la Laguna (NW1389), Lopez s.n. (K, MO). La Paz: Zacatecoluta (NW1388), Calderón 324 (NY). Santa Ana: Montecristo National Park (NW1489), Monterrosa et al. 177 (MO). Sonsonate: Sierra Apaneca, Cerro el Pilón (NW1389), Molina \& Montalvo 21611 (F).

Nicaragua. Río San Juan: Río San Juan between El Tambor and Remolinos (NW1084), Rueda et al. 1903 (MO).

Costa Rica. Cocos Islands: between Wafer and Cerro Iglesias, Foster 4120 (CR, K). Heredia: La Selva Biological Station, confluence of R. Sarapiqui and R. Puerto Viejo (NW1084), Chaverri 287 (INB, MO). Limón: Bribri (NW0982), Gomez et al. 20382 (MO). Puntarenas: Esparza, Macarona, Finca de José V. Herrera (NW0984), Gomez 20711 (K).

Panama. Bocas del Toro: above Chiriqui Grande (NW0882), McPherson 10472 (K, MO). Canal Zone: Madden Forest Reserve (NW0979), Woods \& Gallegos s.n. (F, MO). Chiriqui: W of San Bartolo Limite (NW0882), Croat 22184A (MO). Los Santos: W of Tonosi (NW0780), Holdridge 6226 (MO). Panama: between El Llano and R. Mamon (NW0978), Duke 5627 (MO).

Jamaica. Clarendon: Spaldings to Thompson Town, Bird Cave Rock (NW1877), AcevedoRodríguez 9654 (K, US). Portland: Marce's Gap towards Vinegar Hill (NW1876), Anderson \& Sternberg 3471 (US). St. Andrew: Bellevue Peak, 2 miles W of Cinchona Botanic Garden (NW1876), Kapos 1583 (K, NY). St. Thomas: near Portland Gap (NW1876), Proctor 24023 (NY). Trelawny: 5.3 miles N of Quickstep Postal Agency (NW1877), Thorne \& Proctor 48229 (NY).

Dominican Republic. Pilancon, Bayaguana (NW1969), A. \& P. Liogier 18883 (NY).

Puerto Rico. Caribbean National Forest, El Verde Research Station (NW1865), Boom $10056(\mathrm{~K})$.

Virgin Islands (USA). St. Croix: Montserrat (NW1764), Ryan s.n. (C).

LEeWARd Islands. Guadeloupe: N of Trois Rivières (NW1661), Jeremie 888 (K). Montserrat: Centre Hills (NW1662), J.S. Beard 410 (K, MO). Nevis: Dos d'ane peak (NW1762), J.S. Beard $463(\mathrm{~K})$.

Windward Islands. Dominica: vicinity of Jean, NE of Salisbury (NW1561), Ernst 1818 (F, K). Martinique: Bois Gros, Morne du Lorrain (NW1460), Duss 591/4533 (NY). St. Lucia: Gros Piton (NW1360), P. Beard 1165 (MO). St. Vincent: without exact locality (NW1361), Rev. L.G. s.n. (K).

Colombia. Antioquia: Parque National Natural 'Las Orquideas' Sector Galles (NW0676), Cogollo et al. 2653 (MO).

Venezuela. Bolívar: Altiplanicie de Nuria, $45 \mathrm{~km} \mathrm{~N}$ of Tumeremo, vicinity of Deborah (NW0761), Steyermark 89059 (K). Falcon: 20 km W of Tucacas (NW0968), Cardozo \& Wingfield 190 (K). Tachira: Palo Grande to Minas de Carbon (NW0772), Marcano-Berti \& Sanchez 982065 (K). Yaracuy: Distrito San Felipe, $10 \mathrm{~km} \mathrm{~N}$ of Salom (NW1068), Steyermark \& Espinoza $123802(\mathrm{~K})$.

Tobago. Parrot Hill (NW1160), Broadway 4562 (MO).

Trinidad. Bush Bush Forest, Nariva Swamp (NW1061), Aitken 18197 (K).

Guyana. Pomeroon River, Arunamai Creek (NW0758), FDBG 2527 (K).

SuRINAM. Brownsberg, Brokopondo District (NW0455), LBB 16283 (NY).

ECUADOR. Cañar: near Bucay (SW0279), Camp 3680 (NY). Esmeraldas: Timbre (NW0079), Fagerlind \& Wibom 2492 (US). Guayas: Guayaquil, Cerro Blanco (SW0280), Nuñez \& Yagual 249 (MO). Manabí: 10 km NE of Jama, Hacienda Don Juan (SW0080), Neill et al. 11672 (K). 
Pastaza: Canton Pastaza, Pozo Petrolero 'Moretecocha' de ARCO (SW0177), Gudiño et al. $861(\mathrm{~K})$.

Peru. Loreto: Distrito Nauta, R. Marañon, Quebrada de Sapira (SW0473), Rimachi 4461 (K). Madre de Dios: Tambopata Reserve, R. Tambopata (SW1269), Gentry \& Young 31829 (K). Brazil. Acre: Municipio Santa Rosa, R. Purus, Seringal Mamuria (SW0969), Daly et al. 10064 (K). Amapá: Rio Araguari (NW0151), J.M. Pires et al. 50575 (K, NY). Pará: Macau airstrip, R. Maicuru (SW0054), Strudwick et al. 3419 (K). Rondonia: Municipio Porto Velho $13 \mathrm{~km}$ from Vila Campo Novo (SW1063), Cid Ferreira 8930 (K, US). Roraima: vicinity of Auaris (NW0464), Prance et al. 9850 (K).

Bolivia. Pando: Limoeiro (SW1169), Carballal \& Cardiel 156 (K).

6b. Guarea glabra subsp. excelsa (Kunth) T.D.Penn., stat. nov. - Guarea excelsa Kunth in Humb., Bonpl. \& Kunth, Nov. Gen. Sp. 7: 227 (1825). - Type: Mexico, between Acapulco \& Zumpango, fl., Bonpland s.n. (holo P). Fig. 57C.

Guarea fulva Triana \& Planch., Ann. Sci. Nat. Bot. Ser. 5, 15: 371 (1872).

- Type: Colombia, La Mesa, fr., Triana 3359 (holo P; iso BM, K).

Guarea purpurea C.DC. in A.DC. \& C.DC., Monogr. Phan. 1: 564 (1878). - Type: [Peru] Mexico, fl., Pavon s.n. (holo K).

Guarea filiformis C.DC. in A.DC. \& C.DC., Monogr. Phan. 1: 566 (1878). - Type: Mexico, Oaxaca, fl., Jurgensen 199 (lecto K, designated by Pennington in Pennington et al. (1981: 268); isolecto G).

Guarea filiformis C.DC. var. pallida C.DC., Monogr. Phan. 1: 566 (1878). - Type:

Nicaragua, between Sapoa and Tortuga, fl., Oersted s.n. (herb. no. 80a in C) (holo $\mathrm{C}$; iso $\mathrm{F}$ (fragment), photo NY).

Guarea filiformis C.DC. var. cinerascens C.DC. in A.DC. \& C.DC., Monogr. Phan. 1: 567 (1878). - Type: Mexico, Morelos, Cuernavaca, fl., Bourgeau 1197 (holo K; iso $\mathrm{P})$.

Guarea palmeri N.E.Rose ex C.DC., Bot. Gaz. (Crawfordsville) 19: 39 (1894). - Type: Mexico, Colima, Manzanillo, fr., Palmer 1391 (holo G; iso GH, K, NY, US). Guarea virescens C.DC., Annuaire Conserv. Jard. Bot. Geneve 10: 140 (1907). - Type: Mexico, Guerrero, banks of R. Coyaquilla, fl., fr., Langlassé 917 (holo G; iso $\mathrm{GH}, \mathrm{K}, \mathrm{NY}, \mathrm{P}$, US, photo NY).

Guarea makrinii Blake, Contr. Gray Herb. n.s. 53: 57 (1918). - Type: Mexico, Oaxaca, Pochutla, fl., Conzatti, Reko \& Makrinius 3244 (holo GH; iso MEXU). Guarea excelsa Kunth var. dubia Blake, Proc. Biol. Soc. Washington 34: 116 (1921). - Type: Mexico, Nayarit, Tres Marias Is., fl., Nelson 4230 (holo US; iso A, $\mathrm{F}, \mathrm{GH})$.

?Guarea chiapensis Blake, Proc. Biol. Soc. Washington 34: 116 (1921). - Type: Mexico, Chiapas, Finca Irlanda, fl., Purpus 7374 (holo US; iso GH, MO, NY).

Guarea polyantha Blake, Proc. Biol. Soc. Washington 34: 117 (1921). - Type: Mexico, Guerrero, near Acapulco, fl., Palmer 578 (holo US; iso A, F, GH, K, MO, NY). Guarea heterophylla Blake, Proc. Biol. Soc. Washington 34: 116 (1921). - Type: Mexico, Oaxaca, Pinotepa, fl., Galeotti 7247D (holo US; iso F, G, GH, NY, photo NY). 
Young shoots and inflorescences appressed puberulous to glabrous, leaves glabrous (except for hair tufts), leaflets mostly oblanceolate, apex obtuse to acute or acuminate, secondary veins 6-10 pairs, arcuate, tertiary veins reticulate to oblique, obscure, leaves drying green, petals mostly 4-7 mm long, glabrous, ovary glabrous.

Distribution and ecology. This subspecies is confined to the Pacific drainage of Mexico and Central America from Sinaloa (Mexico) to Costa Rica. It is a tree of riversides, damp ravines and other wet places in tropical deciduous forest, and occasionally recorded from poorly drained savanna and mangrove. Generally at low altitude but ascending to $700 \mathrm{~m}$ in El Salvador and to $1000 \mathrm{~m}$ in Chiapas, Mexico, where it overlaps and intergrades with Guarea glabra subsp. glabra.

Representative additional collections. Mexico. Chiapas: Escuintla, Acacoyagua (NW1592), Matuda 16639 (K). Colima: Manzanillo (NW19104), Palmer 1391 (G, GH, K, NY, US). Guerrero: Acapulco, rd. Puerto Marques (NW1699), Miranda 8407 (MEXU). Jalisco: Municipio la Huerta, Rio Cuitzmala (NW20105), Lott 703 (F, MEXU). Nayarit: Tres Marias Is. (NW21106), Nelson 4230 (A, F, GH, US). Oaxaca: Municipio San Miguel del Puerto, Dist. Pochutla, Xadani (NW1596), Salas et al. 2793 (NY). Sinaloa: Sierra Monterey, Quebrada de Platano, H.S. Gentry 5918 (NY).

Guatemala. Escuintla: near Rio Michatoya, SE of Escuintla (NW1592), Standley 89145 (F). Santa Rosa: region of Capulín, S of Los Cerritos (NW1490), Standley 79645 (F). Zacatépequez: Volcán de Fuego (NW1490), J.D. Smith 2601 (K).

El Salvador. Ahuachapán: San Francisco Menendez, Montaña El Ojushtal (NW1389), Castillo s.n. (K). La Libertad: San Juan Opico Cerro el Jabali (NW1389), Gonzalez \& Hernandez 368 (MO). San Miguel: Laguna de Aramuaca (NW1388), Villacorta et al. 2694 (K). San Vicente: vicinity of San Vicente (NW1388), Standley 21297 (NY).

Nicaragua. Carazo: Rio Grande, 10 km from 'La Trinidad' (NW1186), Araquistain 3769 (K). Chinandega: Volcán Casita, Montañas El Uval (NW1287), Grijalva A. \& M.V. 1459 (K). Granada: Volcán Mombacho, Laguna de Juan Tallo (NW1185), Guzman et al. 565 (K). León: Bellavista, Volcán Casita (NW1286), Moreno 24256 (K). Managua: road to Salamina, along Rio El Carmen (NW1186), Stevens \& Montiel 17151 (K). Rivas: Bosque de Chococente, R. Escalante (NW1186), Araquistain 3795 (K).

Costa Rica. Guanacaste: road Esparta to Cañas, junction to Juntas (NW0984), Pennington 10158 (NY). Puntarenas: Cantón de Aguirre, Savegre (NW0983), Aguilar 1190 (INB, K).

This subspecies is characterised by the usually oblanceolate leaflets with acute, obtuse or obtusely cuspidate apex, and the small \pm glabrous flowers. It is confined to damp places in tropical deciduous forest generally at low altitude, but material collected between $500 \mathrm{~m}$ and $1000 \mathrm{~m}$ grades imperceptibly with Guarea glabra subsp. glabra.

A population intermediate between Guarea glabra subsp. excelsa and G. glabra subsp. glabrescens occurs in the vicinity of Cuernavaca, Mexico at 1400-1500 m altitude. It has the axillary hair tufts and glabrous ovary of Guarea glabra subsp. excelsa, but the leaflet venation of G. glabra subsp. glabrescens. The specimens seen are Pringle 7074, Bourgeau 1197, Croat \& Hannon 65773, Hahn s.n. 
6c. Guarea glabra subsp. microcarpa (C.DC.) T.D.Penn., stat. nov. - Guarea microcarpa C.DC., Bull. Herb. Boissier, Sér. 2, 5: 420 (1905). - Type: Costa Rica, Cartago, Tucurrique, fl., fr., Tonduz \& Pittier 13114 (holo G; iso BM, G, GH, K, M, US, W; photo NY). Fig. 52B.

?Guarea brevianthera C.DC., Smithsonian Misc. Collect. 68: 1 (1917). - Type: Costa

Rica, La Palma, fl., Tonduz 12592 (holo US; iso NY (fragment)).

Guarea arcuata Coronado, Novon 16: 462 (2006), syn. nov. - Type: Costa Rica, Cartago, Brown 17521 (holo F).

Young shoots and inflorescences puberulous to glabrous, leaves glabrous (except for hair tufts), leaflets elliptic to broadly elliptic (often 2-3 times as long as broad), apex mostly acuminate, secondary veins $6-8$ pairs, steeply ascending and strongly arcuate, tertiary veins numerous and close, oblique to perpendicular, leaves drying brownish, petals 5-8 mm long, glabrous, ovary glabrous.

Distribution and ecology. This subspecies is distributed from Nicaragua to Panama, and in South America from Ecuador to southern Peru. In Central America it occurs in wet montane forest between $700 \mathrm{~m}$ and $2200 \mathrm{~m}$ altitude. In South America it is present in both montane and lowland rain forest on the Pacific slopes and in lowland rain forest in Amazonian Ecuador and Peru.

Representative additional collections. Nicaragua. Boaco: Cerro Mombachito, $5 \mathrm{~km} \mathrm{NW}$ of Camoapa (NW1285), Grijalva 2853 (K). Chontales: Cerro Oluma, Cordillera Amerisque, Gentry et al. 43963 (K). Jinotega: Macizos de Peñas Blancas, vicinity of Finca of Manuel Estrada (NW1385), Stevens 11647 (K). Matagalpa: Cerro Matagalpa: Cerro Matapalo, 9 km from Matagalpa (NW1285), Moreno \& Robleto 20468 (K).

Costa Rica. Alajuela: Monteverde Biological Reserve, Rio Peñas Blancas (NW1084), Haber \& Bello 7054 (CR, F, K, MO). Cartago: Turrialba, limite Sur del Monumento Nacional Guayabo (NW0983), Rivera 1946 (CR, F, K). Guanacaste: 3 km N of Santa Elena (NW1084), Haber \& Bello 3810 (CR, K, MO). Heredia: Braulio Carillo National Park, Zurqui Station (NW1084), Boyle 2464 (CR, K). Puntarenas: Coto Brus, San Francisco de Sabalita (NW0882), Alfaro 4137 (INB); Cantón de Puntarenas, San Luis, Monteverde (NW1084), Fuentes 265 (K). San José: Acosta, Sabanillas (NW0984), Sanchez et al. 1152 (CR); NE of San Jeronimo, La Palma area (NW1084), Burger \& Visconti 10212 (F).

Panama. Bocas del Toro: region of Cerro Colorado (NW0881), McPherson 8834 (K, MO). Chiriqui: Las Cumbres, NE of Cerro Punta (NW0882), Schmalzel \& Todzia 2053 (K). Cocle: $7 \mathrm{~km}$ N of El Cope, Rivera Sawmill, Folson et al. 5687 (MO).

ECuAdor. Carchi: Gualpi Alto (NW0078), Thomsen 58825 (K, MO, NY, US). Esmeraldas: Awa Reserve, Mataje (NW0178), Ortiz et al. 37 (K, NY). Guayas: Canton Guayaquil, Bosque Protector Cerro Blanco (SW0279), Rubio et al. 1808 (MO). Napo: Aguarico, Reserva Etnica Huaorani (SW0076), Aulestia M. \& Gonti 1976 (MO). Pastaza: Canton Pastaza, Pozo Petrolero 'Moretecocha' de ARCO (SW0177), Gudiño et al. 902 (MO, NY). Pichincha: Quito - Puerto Quito km 113, Rio Silanche Forest Reserve (NW0079), Acevedo-Rodríguez et al. $1706(\mathrm{NY})$.

Peru. Cuzco: La Convención, below Echarate, Manguyari (SW1272), Nuñez et al. 10205 (MO). Loreto: Distrito Nauta, Rio Marañon, Caserio Florida (SW0473), Rimachi 4461 (NY). Madre de Dios: $39 \mathrm{~km} \mathrm{SW}$ of Puerto Maldonado, Explorers Inn (SW1269), Smith S.F. et al. 962 (K, US). 
This subspecies was treated as an informal 'race' of Guarea glabra in the Flora Neotropica treatment (Pennington et al., 1981). It is defined by the generally broad leaflets c.2 times as long as broad, with few strongly arcuate and convergent secondary veins, and closely parallel, oblique or perpendicular tertiary venation. It is given formal subspecific rank here, due to the reasonable morphological distinctness allied to the ecology and geographical distribution in southern Central America and northwestern South America, which is commonly found in many other species. It is difficult to distinguish from Guarea glabra subsp. glabra in the West Indies, particularly Jamaica and the Leeward Islands.

6d. Guarea glabra subsp. tuerckheimii (C.DC.) T.D.Penn., stat. nov. - Guarea tuerckheimii C.DC. in Donn.Sm., Bot. Gaz. (Crawfordsville) 33: 250 (1902). - Type: Guatemala, Alta Verapaz, Cubilquitz, fl., von Tuerckheim 7835 (? holo G, not traced; iso GH, K, US). Fig. 57D.

?Guarea kegelii Turcz., Bull. Soc. Imp. Naturalistes Moscou 36: 589 (1863). - Type: Guatemala, fl., Kegel 12707 (holo LE, not traced).

Young shoots and inflorescences appressed puberulous to glabrous, leaves glabrous (except for hair tufts), leaflets elliptic to oblong-lanceolate, at least 3 times as long as broad, apex acuminate, secondary veins mostly 8-12 pairs, steeply ascending and arcuate, tertiary veins oblique, leaves drying brown, petals 5-7 mm long, usually with scattered appressed hairs, ovary glabrous.

Distribution and ecology. Distributed from Veracruz, Mexico to Costa Rica. It is a tree of wet lowland rain forest usually below $650 \mathrm{~m}$ altitude, but entering lower montane rain forest in Costa Rica (up to 1000 m altitude). Mostly confined to the Caribbean drainage, the only exception being in the Pacific drainage of Oaxaca and Chiapas (Mexico) and Guanacaste, Costa Rica.

Representative additional collections. Mexico. Chiapas: Lacandona, Ríos Chancalah, Chocoljahito and Tulija (NW1791), Pennington \& Sarukhán 9174 (K, MEXU). Oaxaca: Distrito Miahuatlan, $17.9 \mathrm{~km}$ SW of San Jeronimo Coatlan (NW1696), Torres \& Campos 10840 (F). Puebla: Municipio Ayotoxco, Ayotoxco (NW2097), Ventura 1000 (MEXU, MO). Tabasco: La Palma (NW1791), Matuda 3269 (K). Veracruz: Hidalgotítlan, Brecha Hnos. Cedillo - La Escuadra (NW1794), Vásquez et al. 43 (K).

Guatemala. Alta Verapaz: Municipio Panzos, $6 \mathrm{~km}$ SE of Telemán, Finca Mercedes (NW1589), Stevens et al. 25383 (K). Huehuetenango: between Ixtan and Rio Ixtan, Sierra de los Cuatematanes (NW1591), Steyermark 49239 (F). Izabal: Santo Tomas del Castillo (NW1588), Marshall et al. 405 (NY). Peten: San Pedro, Cadenas road (NW1589), Contreras $9490(\mathrm{NY})$.

Belize. Cayo: 4 miles S of Grand de Oro, Dwyer 10914 (MO). Stann Creek: Middlesex (NW1688), Gentle 2899 (F, K, NY). Toledo: Maya Mountains Bladen Nature Reserve (NW1688), Holst et al. 5364 (K).

Honduras. Atlántida: 5 km SW of La Ceiba, Danto River (NW1586), Hazlett 3236 (F, K). Comayagua: Lake Yojoa, Pito Solo (NW1487), Edwards 410 (K). Cortes: Lake Yojoa, between Las Flores and Balincito (NW1487), Nelson et al. 5885 (K). Gracias a Díos: R. Patuca, Krautara (NW1584), Pennington et al. 13676 (K, MO). Olancho: Rio Olancho, between 
San Esteban and Bonito Oriental (NW1585), Croat \& Hannon 64414 (MO). Yoro: Cascada de Rio Guan Guan (NW1587), Hawkins \& Merello 776 (K).

Costa Rica. Guanacaste: Parque Rincón de la Vieja, Hacienda Santa Maria (NW1085), Herrera 919 (K). Puntarenas: Cantón de Coto Brus, Cordillera de Talamanca, Rio Coton (NW0882), Moraga 292 (K).

Closest to Guarea glabra subsp. glabra but distinguished by the slightly longer leaflets (15-)20-25 cm long, with a long acuminate apex, 8-12 steeply ascending and arcuate secondary veins, and the often rather long inflorescence (15-25 cm long). The corolla size and glabrous ovary are as in Guarea glabra subsp. glabra. Dried specimens often look distinct on account of drying brown, whereas the other subspecies tend to dry green.

The identity of Guarea kegelii is still uncertain, as the type collection has not been traced. It clearly belongs in Guarea glabra, because the leaflets are described as being glabrous except for having hair tufts in the vein axils on the lower surface. It could belong in either Guarea glabra subsp. tuerckheimii or in G. glabra subsp. glabra, both of which have leaves which are glabrous except for axillary hair tufts. The name Guarea kegelii has recently been misapplied to G. bijuga (Coronado, 2006; Rodríguez, 2006), a species lacking hair tufts in the vein axils.

6e. Guarea glabra subsp. glabrescens (Hook. \& Arn.) T.D.Penn., stat. nov. - Sapindus glabrescens Hook. \& Arn., Bot. Beechey Voyage 281 (1838). - Guarea glabrescens (Hook. \& Arn.) Blake, Contr. U.S. Natl. Herb. 23: 559 (1923). - Type: Mexico (probably Tepic [NW21104]), fr., Beechey s.n. (holo K). Fig. 58A.

Guarea fulva Triana \& Planch. var. mexicana C.DC. in A.DC. \& C.DC., Monogr. Phan. 1: 575 (1878). - Type: Mexico, Tepic, fr., Beechey s.n. (holo K).

Young shoots and inflorescences pubescent to tomentose, leaflets pubescent on midrib and veins below, leaflets elliptic to oblong-elliptic, apex shortly acuminate, secondary veins 12-16 pairs, ascending, slightly arcuate, tertiaries oblique to reticulate, leaves drying green to brown, petals 4-5 $\mathrm{mm}$ long, appressed pubescent, ovary pubescent.

Distribution and ecology. Known only from a few collections in the states of Mexico, Guerrero, Jalisco and Nayarit, where it inhabits shady ravines in 'selva mediana caducifolia', between $400 \mathrm{~m}$ and $1300 \mathrm{~m}$ altitude.

Collections examined. Mexico. Guerrero: Teloloapán, rd. Iguala to Ciudad Altamirano (NW1899), Martinez 622 (MEXU); Mina (NW18100), Hinton et al. 10097 (K, MO, NY); Distrito Adama, Achotla (NW18100), Mexia 8900 (K), Reko 4896 (K). Jalisco: Municipio Tecalitlan, before Alotitlan (NW19103), Machuca \& Chazaro 6638 (MEXU); Municipio Cuhautitlan, $6 \mathrm{~km}$ from Telcruz (NW19104), Ramirez et al. 228 (MEXU). Mexico: $25 \mathrm{~km} \mathrm{~S}$ of Amatepec, Terraceria Amatepec-Arcelia (NW18100), Flores \& Terpan 748 (MEXU); District Temascaltepec, Vigas (NW19100), Hinton 3818 (K, NY); District Temascaltepec, Acatitlán (NW19100), Hinton et al. 6189 (K); District Temascaltepec, Nanchititla (NW19100), Hinton et al. 7542 (K, NY, US); District Temascaltepec, Luvianos (NW19100), Hinton et al. 7553 
(K, NY, US). Michoacán: Municipio la Huacana, $7 \mathrm{~km}$ W of Los Ranchos (NW18102), Steinmann 4362 (MEXU). Nayarit: Municipio Compostela la Cascada, $9 \mathrm{~km} \mathrm{NW}$ of Mesillas (NW21105), Flores et al. 901 (MO).

This subspecies is closest to Guarea glabra subsp. excelsa and shares part of its range. It differs in its pubescent leaflets and more numerous secondary veins and in the pubescent ovary. In other respects of floral size and structure it is identical. An intermediate population occurs in the vicinity of Cuernavaca, Morelos (specimens seen are Hahn s.n., Croat \& Hannon 65773, Bourgeau 1197 and Pringle 7074). This population shares the same leaflet size and shape as Guarea glabra subsp. glabrescens, but lacks the leaflet indumentum, apart from hair tufts in the vein axils, and has a glabrous ovary.

6f. Guarea glabra subsp. rovirosae (C.DC.) T.D.Penn., stat. nov. - Guarea rovirosae C.DC., Annuaire Conserv. Jard. Bot. Genève 10: 145 (1907). - Type: Mexico, Tabasco, near Atasta, fl., Rovirosa 542 (holo US; iso K, NY, PH). Fig. 58B.

Guarea petenensis Coronado, Novon 16: 463 (2006), syn. nov. - Type: Guatemala,

Petén, Rio Pasión, Rio Pucte tributary below Sayaxche, between Pucte and La Libertad, fl., Lundell 18164 (holo MO).

Young shoots and inflorescences stiffly pubescent with pale hairs, leaflets usually with some pubescence on midrib and veins below, leaflets elliptic, apex acuminate, secondary veins 7-11 pairs, ascending, arcuate, tertiary veins reticulate to oblique, leaves drying green, petals mostly $4.5-6.5 \mathrm{~mm}$ long, usually with scattered appressed hairs, ovary sparsely strigose or glabrous.

Distribution and ecology. Atlantic and Pacific drainage of southern Mexico, from Oaxaca, Puebla and Veracruz to southern Yucatan Peninsula, Belize and Honduras. It is a small tree of lowland evergreen rain forest, mostly below $500 \mathrm{~m}$ altitude, but present in montane rain forest at $1350 \mathrm{~m}$ altitude in the region of Los Tuxtlas, Veracruz, Mexico.

Representative additional collections. Mexico. Chiapas: Municipio Ocosingo, Yaxchilan (NW1690), Gutierrez 911 (MO). Oaxaca: Municipio Sta. Maria Chimalapa, Rio Verde (NW1694), Caletti et al. 123 (MO). Puebla: Rancho El Ajenjibre, Pennington \& Sarukhán 9294 (K, NY). Tabasco: Balancán, Achotal (NW1791), Matuda 3085 (F). Veracruz: Volcán San Martín (NW1895), Nevling \& Gomez-Pompa 2530 (K).

Guatemala. Izabal: Santo Tomas de Castilla, road to Las Pavas (NW1588), Marshall et al. 418 (NY). Petén: Santa Elena, Laguna Turicentro (NW1689), Ortiz 938 (F).

Belize. Cayo: Chiquibal Forest Reserve, $1 \mathrm{~km}$ from Las Cuevas (NW1688), Ibañez A69 (MO). Orange Walk: Indian Church (NW1788), Arnason \& Lambert 17033 (MO). Toledo: Punta Gorda, Sand Hill (NW1688), Schipp 1001 (K).

Honduras. Comayagua: $7 \mathrm{~km}$ N of La Libertad (NW1487), Hazlett 1688 (MO). Olancho: Valle de Catacamas, near Santa Maria del Real (NW1485), Molina 8423 (F). Yoro: road to Yorito (NW1587), Hazlett 3240 (K).

This subspecies was not given formal rank in the Flora Neotropica treatment (Pennington et al., 1981), but was included within the informal 'race glabra'. 
However, in a recent multivariate analysis of the Guarea glabra complex (Coronado, 2003 ) it was recognised as a distinct species, G. petenensis. It is characterised by the elliptic leaflets with an acuminate apex, the rather stiff pale indumentum on the young parts, also usually present at least on the midrib and veins of the lower leaflet surface, and by the presence of sparse appressed pubescence on the petals and ovary. The leaves usually dry pale green. On the basis of its restricted distribution and the partial morphological distinctness (there are many intermediates with Guarea glabra subsp. tuerckheimii), we are recognising it at subspecific level with the earlier epithet rovirosae.

7. Guarea tonduzii C.DC., Smithsonian Misc. Collect. 68(6): 4 (1917). - Type: Costa Rica, near San Ramon, Tremedal, fr., Tonduz 17677 (holo G; iso BM, CR, F, G, M, S, US, W). Fig. 58C.

Guarea glabra auct. non Vahl: T.D.Penn. in T.D.Penn. et al., Fl. Neotrop. 28: 269 (1981), p.p.

Guarea adenophylla A1.Rodr., Lankesteriana 6: 102 (2006), syn. nov. - Type: Costa

Rica, Puntarenas, Monteverde, Pacific slope, Campbell Farm, fl., Haber \& Zukowski 10791 (holo INB; iso CR, K).

Young shoots 3-5 mm diam., tomentose (golden hairs) at first, soon glabrous and becoming pale whitish grey with some raised brown lenticels. Leaves pinnate with an active terminal bud, petiole $2.5-6 \mathrm{~cm}$ long, semiterete to terete, tomentose at first, becoming glabrous, rhachis up to $40 \mathrm{~cm}$ long, terete, pubescent at first, soon becoming glabrous and eventually woody; petiolule 3-8 $\mathrm{mm}$ long, tomentose at first, becoming glabrous. Leaflets opposite, up to 7 pairs, $(11-) 13-20(-22.5) \times(5-) 5.1-$ $7(-9.8) \mathrm{cm}$, broadly elliptic to broadly oblanceolate, apex acuminate or rarely obtusely cuspidate, base acute, narrowly cuneate or obtuse, coriaceous, upper surface pubescent along the midrib or glabrous, lower surface tomentose to pubescent along the midrib and secondary veins, becoming glabrous on the lamina, sparse to dense minute red papillae nearly always present, occasionally glandularpunctate or -striate; axillary hair tufts absent, venation eucamptodromous, midrib flat on the upper surface, secondaries 9-13(-14) pairs, moderately to steeply ascending, slightly arcuate, slightly convergent, intersecondaries usually absent, tertiaries oblique, rather widely spaced, coarse higher order reticulum visible below. Inflorescence axillary or on twigs below the leaves, 3-10 cm long, a panicle with the lower lateral branches to $5 \mathrm{~cm}$ long, ultimate branches sometimes cymose, tomentose to coarsely pubescent; pedicel 2-3 mm long (above the articulation), tomentose to pubescent. Calyx 1.5-3(-4) mm long, patelliform to shortly cup-shaped, shallowly to moderately 4-lobed or -toothed, pubescent to subglabrous outside, glabrous inside. Petals 4(-5), male and female $8-12 \times 2-3 \mathrm{~mm}$, strap-shaped, apex acute, densely pubescent to subglabrous with a few appressed hairs outside, glabrous inside. Staminal tube 7-10 $\times$ 2-3 mm, tubular (male) to ellipsoid (female), margin truncate to obscurely lobed, glabrous; anthers 8(-10), 8-13 mm long, ellipsoid, glabrous, antherodes in female 
shrunken, without pollen. Nectary $1-1.5 \mathrm{~mm}$ long, a stipe usually expanded into a broad collar beneath the ovary, glabrous. Ovary $1.5-2 \mathrm{~mm}$ long, ovoid, 4-locular, locules 1-ovulate, usually densely pubescent, rarely only sparsely pubescent, male with rudimentary ovules, style 1.5-2 mm long, glabrous, style-head discoid. Capsule $1.5-2.8 \times 1.5-2.8 \mathrm{~cm}$, globose, apex and base rounded, 4-valved, pericarp 1.5-3 mm thick, rough and rather scurfy, sparsely to densely pubescent at first, usually maturing glabrous. Seeds usually 3-4, 1.3-2.4 cm long, shaped like the segment of an orange; embryo with thick plano-convex, superposed to oblique cotyledons, radicle abaxial, included or extending to the surface.

Field characters. Tree to $25 \mathrm{~m}$ high and $50 \mathrm{~cm}$ diam., often flowering when less than $5 \mathrm{~m}$ high. Bark greyish brown, smooth or scaling in small thin pieces, slash pink, with the characteristic scent of the family. Flowers with greenish-cream or pale green petals and whitish staminal tube; mature fruit red, orange or brown; the seed surrounded by an orange sarcotesta. Flowering in Costa Rica is recorded from November to April, with mature fruit throughout the year. In Panama it is from February to March, with a single record of mature fruit in March.

Distribution and ecology. The species occurs only in Costa Rica and Panama, where it is a component of montane rain forest mostly between $700 \mathrm{~m}$ and $1800 \mathrm{~m}$ altitude, rarely up to $2200 \mathrm{~m}$. Specimens from Honduras and Mexico previously referred to this species belong in Guarea bullata.

Representative additional collections. Costa Rica. Alajuela: Zarcero (NW1084), A. Smith 4108 (F). Guanacaste: Monteverde (NW1084), Gentry et al. 71564 (MO). Heredia: Vara Blanca de Sarapiquí (NW1084), Skutch 3621 (US). Puntarenas: Monteverde, Pacific Slope, Campbell Farm (NW1084), Haber \& Zukowski 10791 (CR, INB, K). San José: Dota, Santa Maria de Dota (NW0983), Hammel et al. 24065 (INB).

Panama. Bocas del Toro: Chiriqui border, Fortuna Dam area (NW0882), McPherson 8627 (MO). Chiriqui: between Gualaca and Fortuna Dam site (NW0882), Croat 49955 (MO). Veraguas: Cordillera de Tute, just W of Santa Fé (NW0881), Knapp \& Cress 4339 (K).

Guarea tonduzii is morphologically close to G. bullata, a relationship which is confirmed by the ITS phylogeny, and although the latter is mostly found in lowland forest, both species occur together in montane forest in Costa Rica. The stiff erect or spreading indumentum of Guarea bullata is generally distinct from the more tomentose indumentum of $G$. tonduzii, and the primary, secondary and tertiary venation of G. bullata is nearly always impressed (often strongly so) on the upper surface, whereas that of G. tonduzii is not. The flowers are of similar size, but the ovary of Guarea bullata is usually sparsely strigose, whereas that of $G$. tonduzii is densely pubescent. The fruit of Guarea bullata is smooth whereas that of G. tonduzii is generally roughskinned and scurfy. On this basis a few specimens from Mexico and Honduras which were formally regarded as belonging to Guarea tonduzii are here placed in G. bullata.

Vegetative specimens of Guarea tonduzii can also be confused with G. glabra subsp. microcarpa where the two occur together in montane forest in Costa Rica, but 
the leaflets of G. tonduzii are generally more coriaceous with more numerous secondary veins and they lack the fine parallel tertiary venation which is characteristic of G. glabra subsp. microcarpa.

The recently described Guarea adenophylla, distinguished on the basis of the numerous minute red papillae on the leaf undersurface, is here reduced to synonymy. The presence of minute red papillae is widespread in the genus and in Guarea tonduzii their presence varies from abundant to sparse and provides no basis for subdivision. The leaf indumentum of this species provides a similar example, varying from dense to almost glabrous. The phylogenetic analysis confirms the close relationship of Guarea tonduzii, G. chiricana and G. bullata.

8. Guarea chiricana Standl., [Trop. Woods 16: 18 (1928), nom. nud.] Publ. Field Mus. Nat. Hist., Bot. Ser. 4(1): 215 (1929). - Type: Panama, Chiriqui, Progreso, fl., Cooper \& Slater 164 (lecto F, designated by Pennington in Pennington et al. (1981: 269); isolecto NY, US, Y). Fig. 58D.

Guarea glabra auct. non Vahl: T.D.Penn. in T.D.Penn. et al., Fl. Neotrop. 28: 269 (1981), p.p.

Guarea pilosa Al.Rodr., Lankesteriana 6: 113 (2006), syn. nov. - Type: Costa Rica, Alajuela, Rincon de la Vieja National Park, Rio Jala Piedras, N slope of Volcán Santa Maria, fr., G. Rivera 1098 (holo INB; iso CR, K).

Young shoots $3-5 \mathrm{~mm}$ diam., pubescent at first with stiff erect and spreading pale hairs, usually becoming glabrous, smooth, whitish grey with a few lenticels. Leaves pinnate with an active terminal bud, petiole $2.5-5 \mathrm{~cm}$ long, semiterete, stiffly pubescent to glabrous, rhachis eventually up to $55 \mathrm{~cm}$ long, slightly channelled on the upper surface, stiffly pubescent to glabrous; petiolule 3-5 $\mathrm{mm}$ long, pubescent at first, soon glabrous. Leaflets opposite, 2-4(-5) pairs, (12-)16-25(-31) $\times(4.6-) 5.5-$ 9.5(-17) $\mathrm{cm}$, elliptic, apex acuminate, base acute, chartaceous, upper surface glabrous except for the sometimes stiffly pubescent midrib, lower surface stiffly pubescent on midrib and veins or glabrous, drying pale green on both surfaces, not glandular-punctate or -striate; venation eucamptodromous, midrib slightly sunken on the upper surface, secondaries (9-)10-15(-16) pairs, ascending, straight or slightly arcuate, parallel or slightly convergent, flat or sunken on the upper surface, (rarely strongly sunken and leaves bullate), intersecondaries few or absent, tertiaries oblique, parallel; higher order venation finely reticulate and visible on both surfaces. Inflorescence axillary or on twigs below leaves, 4-15 cm long, often branched near the base and with several slender paniculate branches, indumentum of stiff erect and spreading pale hairs, sometimes becoming glabrous with age, ultimate branchlets and solitary flowers subtended by a minute bract bearing a tuft of stiff pale hairs; pedicel 1.5-2 $\mathrm{mm}$ long (above the articulation), glabrous. Flowers unisexual (plant dioecious). Calyx 1-1.5 mm long, patelliform, with 4 small teeth or lobes, or \pm truncate, with a few scattered hairs outside or glabrous. Petals 4 , male $8-10 \times 1-1.5 \mathrm{~mm}$, female $6.5-8 \times 1-1.5 \mathrm{~mm}$, strap-shaped, apex acute, free, valvate, usually glabrous or rarely 
with sparse short appressed indumentum. Staminal tube in male 6-8 $\times 1.5-2 \mathrm{~mm}$, female $6-6.5 \times 1.5 \mathrm{~mm}$, tubular, margin entire or slightly irregular, glabrous; anthers 8, 0.6-0.7 mm long, oblong, glabrous, antherodes in female similar but not dehiscent. Nectary 1-1.5 mm long, expanded into a collar below the ovary, glabrous, slightly shorter and with a less obvious collar in the female. Ovary 1-2 mm long, ovoid, 4locular, locules 1-ovulate, usually with sparse stiff pale indumentum, rarely densely strigose or glabrous, male with rudimentary ovules, style $1.5-3 \mathrm{~mm}$ long, glabrous, style-head discoid. Capsule 1.3-2 $\times 1.6-2 \mathrm{~cm}$, obovoid to globose, apex rounded or truncate, base obtuse, sometimes with a short stipe, 4-valved, pericarp 1-1.5 mm thick, fleshy, smooth, glabrous or occasionally with scattered residual pubescence, lenticellate or not. Seeds 2-4, 1-1.6 cm long, shaped like the segment of an orange; embryo with thick plano-convex, superposed cotyledons, radicle abaxial, extending to the surface.

Field characters. Treelet or small tree to $25 \mathrm{~m}$ high and $35 \mathrm{~cm}$ diam., but flowering as a small treelet 1-3 m high. Trunk of larger specimens fluted at the base and with pale buff-coloured bark scaling in small deep irregular pieces, slash pale cream, 6-7 mm thick, with characteristic spicy Meliaceous scent. The flowers are whitish and the fruit matures red or pink. The seed is surrounded by a bright orange sarcotesta, which contrasts with the white inner surface of the pericarp. Flowering throughout the range is from December to June. Mature fruit are recorded in February (Nicaragua), January and April to September in Costa Rica, and January, March and October to December in Panama.

Distribution and ecology. Nicaragua, Costa Rica, Panama and Colombia in primary and old secondary lowland and montane rain forest from sea level to $1200(-1500) \mathrm{m}$ altitude. It occurs on both the Atlantic and Pacific drainages in Costa Rica.

Representative additional collections. Nicaragua. Rio San Juan: $1 \mathrm{~km}$ E of Rio Sabalos (NW1184), Moreno 23184 (K, MO). Zelaya: Municipio Nueva Guinea, Boca de Piedra (NW1184), Laguna 129 (K).

Costa Rica. Alajuela: Monteverde Biological Reserve, Rio Peñas Blancas (NW1084), Haber \& Cruz 7102 (CR, MO). Guanacaste: Liberia, PN Guanacaste, Cacao (NW1085), Soto \& Rojas 1751 (INB). Heredia: La Selva Biological Station, Rio Sarapiquí and Rio Puerto Viejo (NW1084), Grayum \& Longino 9307 (CR, K, MO). Puntarenas: Rincón de Osa, between Rincón \& Playa Blanca (NW0883), J. \& K. Utley 1246 (MO); P.N. Isla del Coco, Bahía Chattan (NW0587), Quesada 1121 (K). San José: Dota, track to Tijerilla (NW0983), Valverde 838 (F, K); Acosta, Cuenca del Pirris-Damas (NW0984), Morales 8145 (INB).

Panama. Bocas del Toro: near highway to Chiriqui Grande (NW0882), McPherson 11814 (MO). Canal Zone: 12 miles S of Colon, vicinity La Providencia (NW0979), Blum \& Tyson 2335 (MO). Chiriquí: Puerto Armuelles to San Bartolo Limite (NW0882), Croat 35061 (K, MO). Cocle: 7 km N of El Cope, Alto Cavario (NW0880), Folsom 4169 (K, MO). Colon: Salud (NW0980), Lao \& Holdridge 174 (MO). Panama: Parque Nacional Altos de Campana (NW0879), Galdames 1075 (F). San Blas: El Llano-Carti road, $19.1 \mathrm{~km}$ from Interamerican Highway (NW0978), de Nevers 3778 (K). Veraguas: Cerro Tute, Cordillera de Tute, W of Santa Fe (NW0881), Knapp \& Sytsma 2580 (K).

Colombia. Antioquia: Municiípio Taraza, Corregimiento 'El 12' (NW0775), Callejas \& Betancur 3518 (K, NY). 
Guarea chiricana differs from G. glabra in lacking the hair tufts in the axils of the secondary veins and in the distinctive indumentum of the young shoots, lower leaf surface and inflorescence. It also has slightly more numerous secondary veins, and the higher order venation forms a fine reticulum which is visible on both surfaces. Its corolla is generally slightly longer than that of Guarea glabra and the ovary generally has some indumentum. It differs from Guarea bijuga in the characteristic indumentum of the young shoots, leaves and inflorescence, shorter calyx, pubescence of the ovary and smooth capsule. The finely reticulate higher order venation also distinguishes it from Guarea bullata, and its leaflets are rarely bullate and they dry pale green on both surfaces (brown in G. bullata). The corolla of Guarea chiricana is nearly always glabrous whereas that of $G$. bullata has stiff dense appressed pubescence.

Guarea chiricana is most likely to be confused with G. glabra subsp. rovirosae which has a similar venation and leaflet shape. It differs in the more numerous secondary veins, and in the longer and more slender, usually glabrous corolla.

Guarea pilosa is here reduced to synonymy. It is a slightly more pubescent form of the species and distributed throughout its range.

A small number of collections from the Fortuna Dam area, Chiriqui, Panama, are included in this species with some reservations. They differ from typical Guarea chiricana in their slightly to strongly bullate leaflets. The fruit are typical of the species, but the flowers have not yet been collected. The collections seen are Churchill et al. 4765 (MO), Galdames et al. 647 (K), McPherson 7698 (K), Valdespino et al. 470 (NY) and Valdespino et al. $583(\mathrm{MO})$.

9. Guarea bullata Radlk., Bull. Herb. Boissier, Sér. 2, 5: 192 (1905). - Type: Costa Rica, Cartago, Tucurrique, fr., Tonduz 12838 (holo CR; iso BM, M, P). Figs 8, 59A. Guarea glabra auct. non Vahl: T.D.Penn. in T.D.Penn. et al., Fl. Neotrop. 28: 269 (1981), p.p.

Young shoots 3-6 $\mathrm{mm}$ diam., densely pubescent with pale straw-coloured to ferrugineous stiff erect or spreading hairs, eventually becoming glabrous, pale greyish white, smooth, with some elongate lenticels. Leaves pinnate with an active terminal bud, petiole $2.5-5 \mathrm{~cm}$ long, semiterete, pubescent, eventually becoming glabrous, rhachis to $50 \mathrm{~cm}$ long, semiterete and sometimes channelled on the upper surface, pubescent at first with stiff, erect or spreading hairs, becoming glabrous and woody as the lower leaflets fall; petiolule 3-6(-10) $\mathrm{mm}$ long, pubescent. Leaflets opposite, up to 8 pairs, $(9.2-) 12-20(-31) \times(2.7-) 4.2-6(-7.4) \mathrm{cm}$, elliptic to oblanceolate, apex nearly always acuminate, rarely obtusely cuspidate, base acute to narrowly cuneate, thinly coriaceous, upper surface glabrous except for residual indumentum along the midrib, lower surface with stiff erect or spreading pubescence along the midrib and secondary veins, becoming glabrous with age, drying brown, sparsely glandular-striate; venation eucamptodromous, midrib sunken on the upper surface, secondaries (10-)11-15(-16) pairs, moderately to steeply ascending, straight or slightly arcuate, parallel or slightly convergent, intersecondaries moderately 


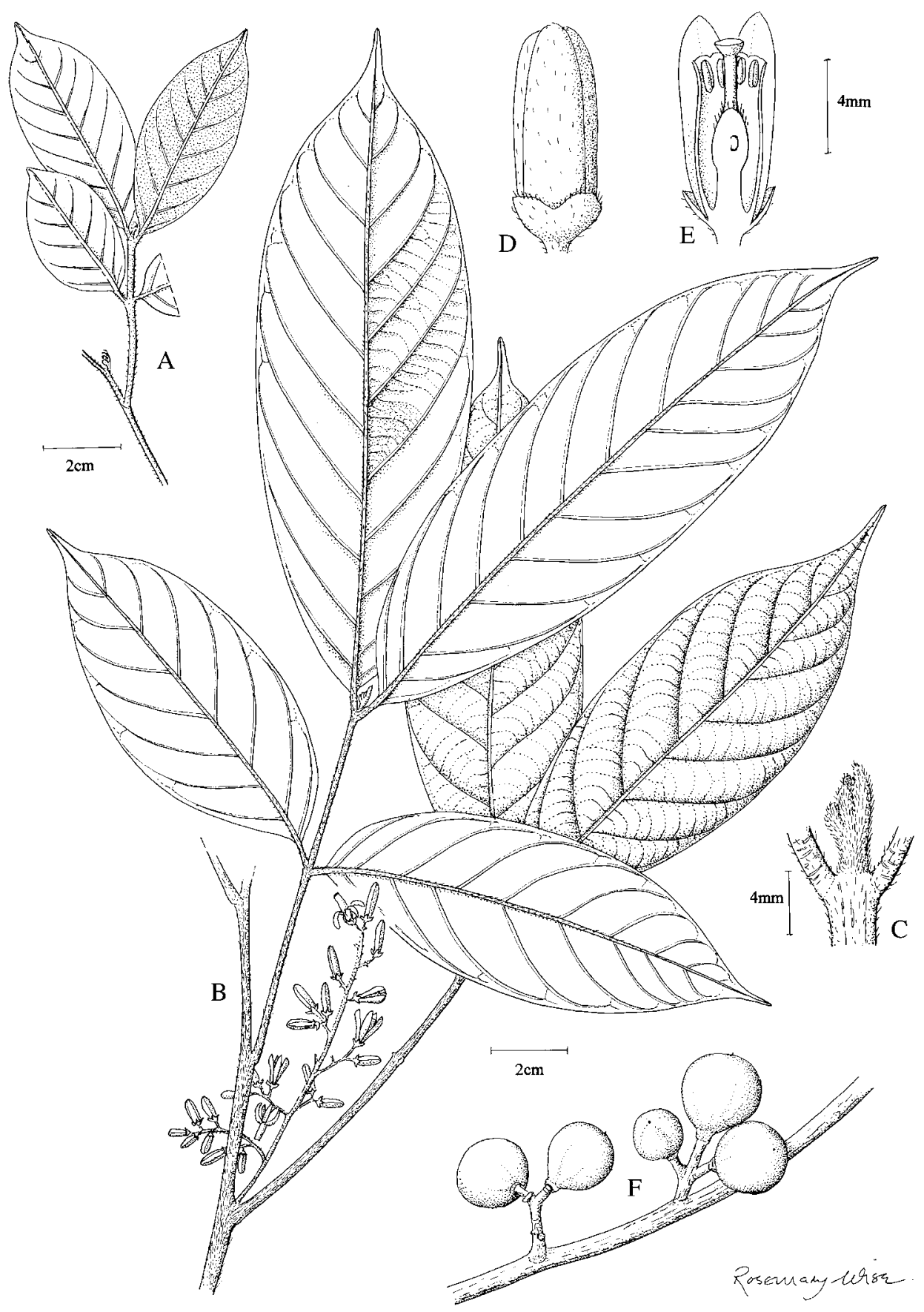

FIG. 8. Guarea bullata Radlk. A, young leaf; B, habit; C, dormant bud at leaf apex; D, flower bud; E, half-flower; F, fruit. (A, D-E, Herrera 918; B, C, Skutch 2665; F, Liesner 2039). 
developed or absent, tertiaries oblique, parallel, secondary and tertiary venation often strongly impressed on the upper surface (bullate). Inflorescence axillary or on old wood below the leaves, 3-10 cm long, often clustered, a slender or narrowly pyramidal thyrse, the lower branches up to $3 \mathrm{~cm}$ long, sparsely to densely pubescent with stiff erect or spreading hairs; pedicel 1-3 mm long, pubescent. Calyx (1-)2$3 \mathrm{~mm}$ long, patelliform to cup-shaped, margin entire or with 4 shallow teeth or lobes, with sparse stiff pubescence outside, glabrous inside. Petals 4, (male and female) 7$11 \times 1.5-3 \mathrm{~mm}$, strap-shaped, apex acute, free, valvate, with pale stiff appressed pubescence outside, glabrous inside. Staminal tube (male and female) 5-9.5 $\times 2-$ $3 \mathrm{~mm}$, tubular, margin undulate, glabrous; anthers $8(-10), 1-1.2 \mathrm{~mm}$ long, oblong, glabrous, antherodes in female similar but not dehiscent. Nectary 1.5-2.5 mm long, a stipe expanded into a broad collar below the ovary, shorter, broader and less expanded in the female. Ovary c. $2 \mathrm{~mm}$ long, 4(-5)-locular, locules 1-ovulate, ovoid, nearly always sparsely strigose, rarely glabrous, male more slender with rudimentary ovules, style 1.5-3.5 mm long, glabrous, style-head discoid. Capsule 1.5-3.2 $\times 1.5-$ $3.5 \mathrm{~cm}$, globose or turbinate, apex rounded to truncate, base rounded or obtuse, 4(-5)-valved, valves 1-seeded, pericarp 2-5 mm thick, smooth, nearly always glabrous (densely pubescent in Honduras), often lenticellate. Seeds 3-5, 1.2-2.5 cm long, shaped like the segment of an orange; embryo with thick plano-convex, obliquely superposed cotyledons, radicle abaxial, extending to the surface.

Field characters. Tree to $20(-35) \mathrm{m}$ high and $80 \mathrm{~cm}$ diam., but often flowering as a small treelet of 3-10 m high; bark brown, shallowly fissured and slash with the characteristic Meliaceous scent; flowers creamish-white or rarely tinged with pink; the fruit maturing pink, red or orange. Flowering in Mexico is recorded in June and August, but in Costa Rica throughout the year, and records of mature fruit vary widely: July (Mexico), May (Honduras), mostly January to August (Costa Rica), February to March (Panama), October to November (Colombia) and August (Ecuador).

Distribution and ecology. Distributed southwards from the Caribbean slopes of Veracruz, Mexico to Chiapas and along the Caribbean drainage of Honduras and Nicaragua to Costa Rica, Panama, Colombia and Pacific Ecuador. Not yet recorded from Belize or El Salvador. A species of lowland and montane rain forest from near sea level to $1200 \mathrm{~m}$ altitude.

Representative additional collections. Mexico. Oaxaca: Municipio Santa Maria, Chimalapa, $10 \mathrm{~km} \mathrm{~S}$ of Santa Maria (SW1694), Hernandez 1401 (MO). Veracruz: San Andrés Tuxla, Los Tuxtlas Tropical Biological Station (NW1895), Ibarra \& Sinaca 1757 (MO, NY).

Honduras. Atlantida: N slope of Pico Bonito, E of new CURLA (NW1585), Evans $1581(\mathrm{~K})$.

Nicaragua. Rio San Juan: Bocas de Sabalo (NW1184), Moreno 26755 (MO). Zelaya: El Achote (NW1184), Araquistain 3135 (K).

Costa Rica. Alajuela: Canton de San Carlos, $1.5 \mathrm{~km} \mathrm{~S}$ of Chachagua (NW1084), Haber 11797 (INB, K); Upala, Cuenca del Zapote, El Pilon (NW1085), Jiménez \& Lopez 181 (INB). Cartago: Turrialba, Potrero Rejoyon (NW0983), Pennington \& Budowski 10108 (NY). 
Guanacaste: Parque Rincón de la Vieja (NW1085), Herrera 918 (CR, F). Heredia: Finca la Selva, OTS Field Station (NW1084), Chacón 1122 (MO). Limón: Talamanca, Finca la Culebra (NW0982), Gomez-Laurito \& Gomez 12342 (CR). Puntarenas: Golfo Dulce Forest Reserve, Aguabuena (NW0883), Aguilar 708 (INB, K). San José: vicinity of El General (NW0983), Skutch 2665 (K, NY, US).

Panama. Bocas del Toro: Quebrada Bonyic (NW0982), Santamaria \& Lara 1098 (MO). Darien: Distrito Pinogama, Corregimento El Real, $6 \mathrm{~km}$ E of El Real (NW0877), Berry et al. 5421 (K). Antioquia: Município Turbo, road Tapon del Darien km 11 (NW0876), Brand \& Gonzalez 509 (MO).

Ecuador. Esmeraldas: Anchayacu, Eloy Alfaro, Mayronga (NW0079), Pennington et al. 14928 (NY). Los Ríos or Pichincha: Patricia Pilar to 24 de Mayo, El Centinela (SW0079), Dodson \& Gentry 12420 (F, MO).

Colombia. Antioquia: Municipio Mutatá, Río Surumbay (NW0776), Callejas et al. 5747 (K, MO).

This species differs from Guarea glabra in lacking the hair tufts in the vein axils, in the stiff spreading or erect indumentum on the young shoots, lower leaf surface and inflorescence, in the impressed venation on the upper leaflet surface (often bullate), and in its longer petals with appressed indumentum, and in the usually sparsely strigose ovary. It is sometimes difficult to distinguish from Guarea tonduzii where the two species co-occur in montane rain forest in Costa Rica, as both have a similar indumentum and flower size.

10. Guarea kunthiana A.Juss., Bull. Sci. Nat. Géol. 23: 240 (1830); Mém. Mus. Hist.

Nat. 19: 241, 290 (1831); T.D.Penn. in T.D.Penn. et al., Fl. Neotrop. 28: 312 (1981). - Type: French Guiana (Cayenne), fl., fr., Poiteau s.n. (holo P-JU (without data); iso G, K). Figs 9, 63A.

For synonymy see T.D.Penn. in T.D.Penn. et al., Fl. Neotrop. 28: 312-313 (1981).

Abbreviated description. Young shoots and inflorescences appressed puberulous to sparsely or densely softly pubescent, leaves with a terminal bud showing intermittent growth, leaflets $2-6(-10)$ pairs (leaves rarely 1-foliolate), $(10-) 15-25(-34) \times(3.5-) 5-$ $10(-20) \mathrm{cm}$, elliptic or oblanceolate, chartaceous to coriaceous, usually glabrous, less frequently lower surface sparsely to densely puberulous or softly pubescent, higher order (tertiary) venation obscure, inflorescence usually axillary, often with indeterminate apical growth (1-)3.5-25(-30) cm long, a pyramidal thyrse, lower branches to $12 \mathrm{~cm}$ long, petals (3-)4, valvate, (6-)7-12(-13.5) $\mathrm{mm}$ long, staminal tube 5.5-10 mm long, (1.5-)2-3(-4) mm broad, often narrowed at the apex, anthers (7-)8(-10), ovary (3-)4-locular, locules with 2 superposed ovules, nearly always glabrous, capsule $1.5-4.5(-7.5) \times 1.5-3.5(-6.5) \mathrm{cm}$, ellipsoid to globose, usually somewhat constricted between the seeds, and often slightly quadrangular in section, smooth, glabrous, usually with pale lenticels, 4-valved, pericarp 1-4 mm thick, valves with 2 superposed seeds.

Distribution and ecology. From Nicaragua southwards across the whole of tropical South America to Bolivia, Paraguay, southern Brazil and northern Argentina. Also 


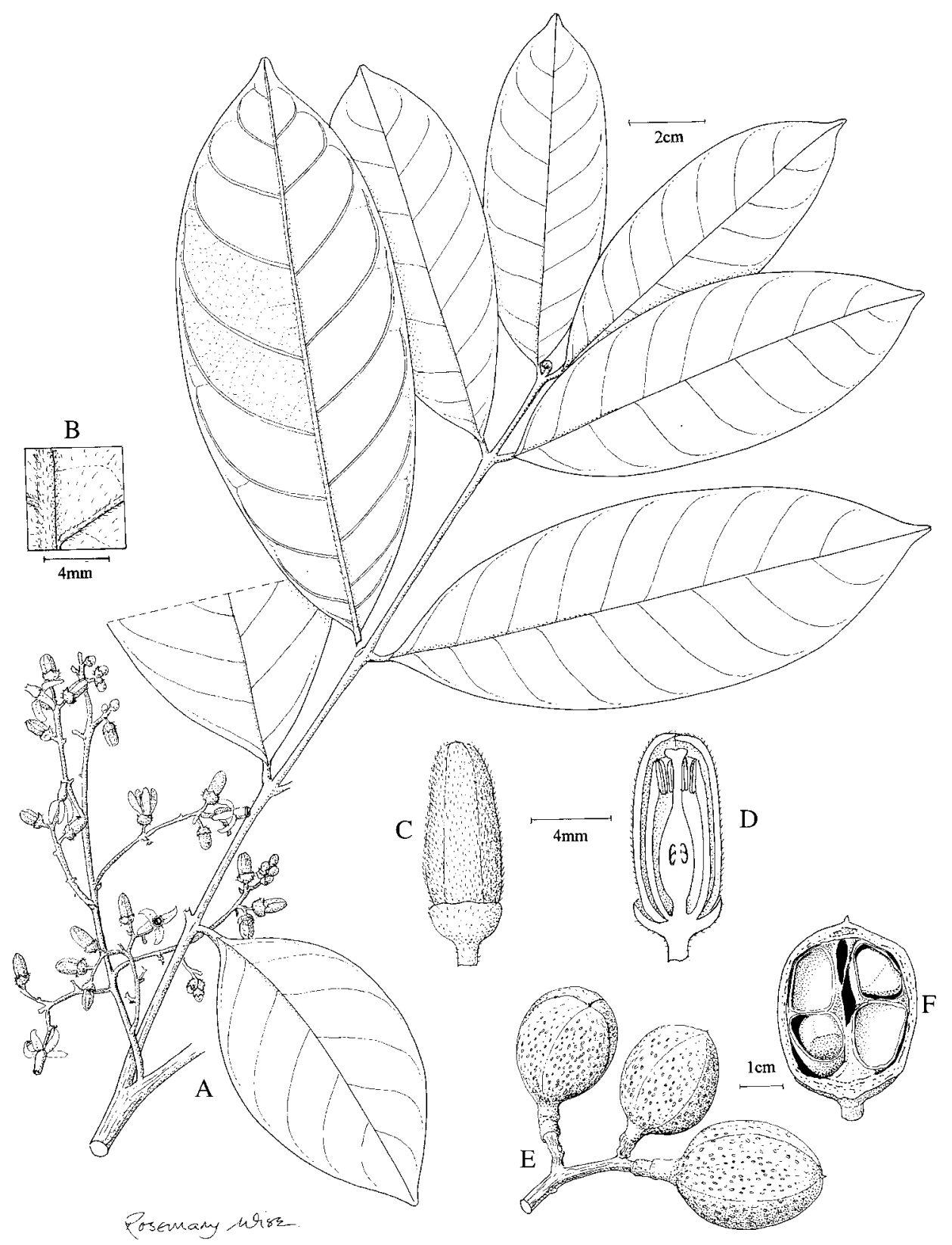

FIG. 9. Guarea kunthiana A.Juss. A, habit; B, enlargement of leaf undersurface; C, flower bud; D, half-flower; E, fruit; F, section of fruit. (A, B, Wallnöfer \& Tarin 13497; C, D, Mori \& Pipoly 15615; E, Mori \& Gracie 18330; F, Jaramillo et al. 656). 
present in the Lesser Antilles (Dominica and Martinique). A common component of evergreen lowland rain forest on non-flooded land and also ascending to wet montane forest in the Andes (up to $2500 \mathrm{~m}$ altitude). In the drier, more seasonal areas of southeastern Brazil it is confined to gallery forest along rivers.

Representative additional collections. Nicaragua. Rivas: Isla Ometepe, Volcan Maderas (NW1185), Robleto 741 (K).

Costa Rica. Alajuela: Upala, Colonia Libertad (NW1085), Herrera 1964 (K). Cartago: Rio Grande de Orosi, Tapanti (NW0983), Grayum \& Sleeper 3452 (MO). Guanacaste: 3 km N of Santa Elena (NW1084), Haber ex Bello 3799 (K). Limón: Cerro Coronel (NW1083), Stevens 23849 (K). Puntarenas: Cantón Golfito, PN Corcovado, Sirena (NW0883), Aguilar 3437 (INB); Nicoya Peninsula, Curu (NW0984), Sanders et al. 19289 (MO).

Panama. Chiriquí: Fortuna Dam region, Quebrada Arena (NW0882), McPherson 8729 (K). Windward IsLANDS. Dominica: vicinity of Jean, NE of Salisbury (NW1561), Ernst 1818 (US).

Colombia. Amazonas: Araracuara, Rio Caquetá (SW0072), Londoño et al. 1541 (K). Antioquia: Guatape, Vereda Santa Rita (NW0675), Escobar et al. 8210 (K). Nariño: Município Barbacoas, Vereda El Barro (NW0178), Franco et al. 5167 (NY). Putumayo: Municipio Mocoa, Vereda Alto Campucana (NW0176), Betancur et al. 5215 (K). Valle: $7 \mathrm{~km} \mathrm{~N}$ of Caicedonia, Finca La Carmelita (NW0475), Silverstone-Sopkin \& Paz 6943 (K).

Venezuela. Carabobo: Municipio Autonomo Mara, R. Moron (NW1068), Diaz \& Niño 266

(K). Yaracuy: Serrania de Aroa, N of Urachiche (NW1069), Meier et al. 5651 (K).

GuYana. Upper Takutu-Upper Essequibo Region, Acarai Mts. (NW0158), D. Clarke et al. 7677 (U).

French Guiana. Saül (NW0353), Mori \& Pipoly 15615 (K).

EcuAdor. Cotopaxi: Sigchos, Triunfo Grande-Sigchos (SW0078), Ramos et al. 6890 (MO). Esmeraldas: San Lorenzo, Alto Tambo (NW0078), Quelal et al. 439 (K). Loja: Cerro Uritusinga (SW0479), Jorgensen et al. 1120 (K). Morona-Santiago: $35 \mathrm{~km} \mathrm{~N}$ of Gualaquiza (SW0378), Pennington \& Tenorio 10771 (K). Orellana: Yasuní National Park, Maxus road, km 40 (SW0076), M. Aulestia 2714 (K). Pastaza: Pastaza Cantón, Villano (SW0177), Espinoza \& Gualinga 835 (K). Pichincha: Puerto Quito-La Union (NW0079), Jaramillo 7747 (K). Sucumbios: Comuna El Pilchi (SW0076), Freire \& Chavez 5372 (K). Zamora-Chinchipe: Rio Nangaritza, Campamento Shaime (SW0478), van der Werff et al. 13014 (K).

Peru. Amazonas: Florída-Rioja km 31 (SW0577), Pennington \& Daza 16807 (K, MOL). Huánuco: junction of R. Pachitea \& R. Yuyapichis, Panguana (SW0974), Morawetz \& Wallnöfer 113-21085 (K). Madre de Dios: Manu, Manu National Park, Cocha Cashu (SW1171), Chatrou et al. 128 (K). Piura: Montaña de Cuyas, 8 km NE of Ayabaca (SW0479), Gentry et al. 75061 (K). San Martín: Rioja Prov., Pedro Ruiz to Moyabamba km 390 (SW0577), D.N. Smith \& Vásquez 4738 (K). Ucayali: Prov. Purus, Rio Curanja (SW1071), Graham \& Schunke 902 (K).

Brazil. Acre: Municipio Tarauaca, Seringal Vitoria Velha (SW0870), Figueiredo et al. 933 (NY). Amazonas: Municipio Atalaia do Norte, R. Javari, Estirão de Equador (SW0471), Cid Ferreira et al. 9904 (K). Bahía: Ilheus to Itabuna km 22 (SW1439), Hage \& Brito 2198 (K). Distrito Federal: APA de Cafuringa, Fazenda Palestina (SW1547), Pereira 2247 (K). Goias: Chapada dos Veadeiros, Fazenda Pai José (SW1447), Mendonça \& Cesar 2224 (K). Mato Grosso: Serra das Araras (SW1556), Dubs 1293 (K). Mato Grosso do Sul: Municipio Bonito, Cachoeira do Rio Aquadaban (SW2156), Hatschbach et al. 74130 (K). Pará: Lageira (SW0054), Strudwick et al. 3855 (K).

Bolivia. La Paz: Iturralde, Santa Fe (SW1368), De Walt et al. 765 (K). Santa Cruz: Ichilo, SE of Buena Vista (SW1763), Nee 45246 (K).

Paraguay. Alto Paraná: Estáncia Rio Bonito (SW2554), Zardini \& Vera 42606 (K). Amambay: Estáncia la Serrana (SW2255), Zardini \& Cardozo 45095 (K). Caazapa: Estáncia 
Golondrina, Ypeti (SW2555), Zardini \& Hellman 49000 (K). Guaira: Cordillera de Ybytyruzu (SW2456), Zardini \& Aguayo 14074 (K). San Pedro: Yaguarete (SW2355), Zardini \& Garcete $43331(\mathrm{~K})$.

Argentina. Misiones: Eldorado, banks of R. Paraná (SW2654), Burkart 14558 (K).

Although this species has the typical flower and fruit structure of Guarea, it is probably the easiest species to identify, even in a vegetative state. This is due to the characteristic leaf venation, with obscure and widely separated tertiary veins, the glabrous ovary and smooth lenticellate fruit. Its rather isolated position within Guarea is confirmed by the ITS phylogeny.

11. Guarea jamaicensis Proctor, Bull. Inst. Jamaica, Sci. Ser. 16: 19, t. 6 (1967); T.D.Penn. in T.D.Penn. et al., Fl. Neotrop. 28: 320, fig. 66 (1981). - Type: Jamaica, Parish of St. James, White Rock Hill, fl., Proctor 23188 (holo IJ; iso GH, NY). Fig. 66A.

Abbreviated description. Young shoots and inflorescences minutely appressed puberulous, leaves with a terminal bud showing intermittent growth, leaflets $(2-) 3-4(-5)$ pairs, $6.5-8.5 \times 3-4 \mathrm{~cm}$, elliptic to broadly oblanceolate, coriaceous, glabrous, venation eucamptodromous to brochidodromous, secondaries 9-10 pairs, inflorescence axillary, 2-3 cm long, a few-flowered raceme or panicle, petals 4 , c.8.5 mm long, valvate, staminal tube 6-6.5 mm long, $2.5-3 \mathrm{~mm}$ broad, anthers 8 , ovary 3-4-locular, locules with 1-2 collateral or superposed ovules, capsule $1.3-1.6 \mathrm{~cm}$ diam., globose, smooth, sparsely appressed puberulous, 3-4-valved, pericarp c. $1 \mathrm{~mm}$ thick, valves with 1-2 collateral seeds.

Field characters. Fruiting recorded in February, July and November.

Distribution and ecology. Jamaica, on forested limestone hills, between $700 \mathrm{~m}$ and $1000 \mathrm{~m}$ altitude.

Additional collections examined. Jamaica. St. Ann Parish, Broom Hall Woods (NW1877), Gentry et al. 28434 (K); Clarendon, Cecil Lindo's Estate (NW1877), Goodfriend s.n. (F); St. Ann, W of Prickly Pole P.A., Proctor 38428 (NY).

A genetically isolated species, possibly related to Guarea sphenophylla (based on their geography and morphology), but no ITS sequence data were available from the latter to confirm this hypothesis.

12. Guarea pterorhachis Harms, Notizbl. Bot. Gart. Berlin-Dahlem 9: 141 (1924); T.D.Penn. in T.D.Penn. et al., Fl. Neotrop. 28: 326, fig. 68 (1981). - Type: Peru, Loreto, Middle Ucayali, fl., Tessmann 3164 (holo B, destroyed; lecto G, designated here; isolecto NY).

For synonymy see T.D.Penn. in T.D.Penn. et al., Fl. Neotrop. 28: 326 (1981).

Abbreviated description. Young shoots and inflorescences sparsely appressed puberulous, leaves with a terminal bud showing intermittent growth, petiole and rhachis 
broadly winged, leaflets $2-6$ pairs, $10-34 \times 3.5-11 \mathrm{~cm}$, oblong to narrowly elliptic, chartaceous to coriaceous, glabrous, higher order venation obscure, inflorescence 35-80 cm long, a much-branched thyrse with widely spreading branches, the lower ones up to $70 \mathrm{~cm}$ long, flowers in dense subfasciculate clusters, petals 4 , valvate or slightly imbricate towards the apex, (3.5-)4-5 mm long, anthers (7-)8, ovary 2-locular, locules with 2 superposed ovules, glabrous, capsule $1.5-2 \mathrm{~cm}$ long, ellipsoid and borne obliquely on the pedicel (when 1-seeded) or bilobed and constricted between the valves (when 2-seeded), smooth, glabrous, 2-valved, pericarp $0.75-1 \mathrm{~mm}$ thick, seed solitary or 1 in each valve.

A distinct species, differing from all others by the broadly winged leaf rhachis. It shares some floral characters with Guarea silvatica, such as the slightly imbricate petals and 2-locular glabrous ovary. The ITS phylogeny confirms its isolated position at the end of a long branch and sister to all other South American species.

Key to the subspecies of Guarea pterorhachis

1a. Venation eucamptodromous, the secondary veins gradually diminishing and disappearing below the margin

12a. G. pterorhachis subsp. pterorhachis

1b. Venation brochidodromous, the secondary veins joining just below the margin in a strong \pm straight submarginal vein running parallel to the margin

12b. G. pterorhachis subsp. submarginalis

12a. Guarea pterorhachis subsp. pterorhachis. Fig. 52C.

Distribution and ecology. Nicaragua, Costa Rica and Panama, Amazonian Colombia, Ecuador (including the Pacific drainage (Canar)), Peru, Bolivia and western Amazonian Brazil. A species of lowland and montane rain forest up to $1000 \mathrm{~m}$ altitude, mostly on non-flooded land but occasionally recorded from periodically flooded forest in western Amazonia.

Representative additional collections. Nicaragua. Chontales: foot of Loma San Gregorio, Sandino 5169 (K). Matagalpa: Macizos de Peñas Blancas, SE side, Quebrada el Quebradon (NW1383), Stevens et al. 21384 (K). Zelaya: Municipio de Siuna, Caño el León (NW1384), Ortiz 726 (K).

Costa Rica. Alajuela: Monteverde Reserve, Rio Peñas Blancas (NW1084), Bello 1631 (INB, K). Guanacaste: Rincón de la Vieja National Park (NW1085), Rivera \& Dennis 1103 (K). Limón: Hitoy Cerere Biological Reserve (NW0983), Herrera \& Chacon 2343 (K). Puntarenas: Cantón de Golfito Jimenez, Alto de Carbonera (NW0883), Herrera 4312 (CR, K); Cantón de Osa, near Dominical (NW0983), Fernandez 511 (INB). San José: Puriscal, Cerro Pilon (NW0984), Morales 3938 (INB).

Panama. Colon: Santa Rita Ridge (NW0979), McPherson 9180 (K). Herrera: W of Las Minas, Montosa de Chepo (NW0780), McPherson 10949 (K).

Ecuador. Cañar: E of Manta Real (SW0279), Cornejo \& Bonifaz 3680 (K). MoronaSantiago: Cordillera de Condor, Centro Shuar Warints (SW0378), Kajekai et al. 13 (K). Orellana: $30 \mathrm{~km} \mathrm{NW}$ of Coca, Huashito (SW0077), Pennington 10593 (K). Pastaza: Rio 
Pastaza, between Chiriboga and Apachi Entza (SW0276), Ollgaard et al. 35166 (K). ZamoraChinchipe: Nangaritza (SW0478), Quizhpe et al. 466 (K).

Peru. Amazonas: Bagua Province, Yamayakat (SW0478), Vásquez \& Jaramillo 20317 (K). Huánuco: Yuyapichis, Puerto Inca, DANTAS (SW0975), Tello 376 (K). Ucayali: Purus, Rio Curanga, Colombiana (SW1071), Graham \& Schunke 147 (K).

Brazil. Acre: Fazenda Bom Sossego (SW0773), Campbell et al. 9509 (K). Rondonia: Municipio de Costa Marques, Chapada dos Parecis (SW1162), Cid et al. 4525 (K).

Bolivia. Beni: Prov. Ballivian, Serrania Pilon Lajas (SW1567), Solomon 13899 (K). Santa Cruz: Ichilo, S of San Rafael (SW1763), Nee \& Saldias 36877 (K).

12b. Guarea pterorhachis subsp. submarginalis T.D.Penn., subsp. nov. Figs 10, 52D. Ab subspecie pterorhachidi venatione brochidodroma, nervi submarginali valido differt. - Type: Colombia, Choco, Quebrada Argueta, S of Rio Mecana [NW0677], fl., Juncosa 1717 (holo K; iso MO).

Distribution and ecology. Pacific drainage of Colombia, known from Antioquia, Choco and Valle. It has the same ecology as the typical subspecies and is present in wet lowland and montane rain forest from sea level to $1400 \mathrm{~m}$ altitude. It is, however, geographically distinct from the typical subspecies, which in Colombia is known only from the extreme southeast corner of the Amazon.

Field characters. Tree to $15 \mathrm{~m}$ high with cream-coloured flowers. Flowering and fruiting recorded March to April.

Collections examined. Colombia. Antioquia: 'Las Orquideas' National Park track to San Mateo (NW0676), Cogollo et al. 3321 (MO), Rio Venados (NW0676), Cogollo et al. 3573 (MO); Murri la Blanquita, Rio Murri (NW0676), Gentry et al. 75806 (MO); Municipio Frontino, Nutibara (NW0676), Luteyn et al. 12127 (K). Choco: Bahía Solan Municipio, Corregimiento El Valle (NW0676), Espina et al. 2620 (K, MO); Municipio San José del Palmar, vereda la Badea (NW0476), Franco et al. 1804 (MO); area of Baudo, Rio Baudo (NW0477), Fuchs \& Zanella 22074 (MO, NY, US). Valle: Río Calima, La Trojita (NW0477), Cuatrecasas 16598 (F, US); Municipio Buenaventura, Campamento El Chanco (NW0476), Devia 1209 (MO); Bajo Calima Concesion, 16 km NW of Buenaventura (NW0477), FaberLagendoen \& Renteria 1044 (K); Bahía Malaga near Juanchaco, Gentry et al. 53365 (K, MO); Concesión Pulpapel/Buenaventura, Bajo Calima (NW0377), Monsalve 1929 (MO).

This subspecies was first collected by Cuatrecasas (no. 16598) in 1944 and noted as possibly distinct in Flora Neotropica (Pennington et al., 1981: 329). The collection of complete material since 1981 enables its recognition as a subspecies of Guarea pterorhachis. The flowers and fruit do not differ from those of the typical subspecies but the brochidodromous venation with a well-defined submarginal vein is consistently different. It is also geographically distinct from the typical subspecies.

13. Guarea caulobotrys Cuatrec., Fieldiana, Bot. 27(1): 69 (1950); T.D.Penn. in T.D.Penn. et al., Fl. Neotrop. 28: 345 (1981). - Type: Colombia, Dept. del Valle, Costa del Pacífico, R. Naya [NW0377], fl., Cuatrecasas 14103 (holo F; iso COL). Figs 11, 52E. 


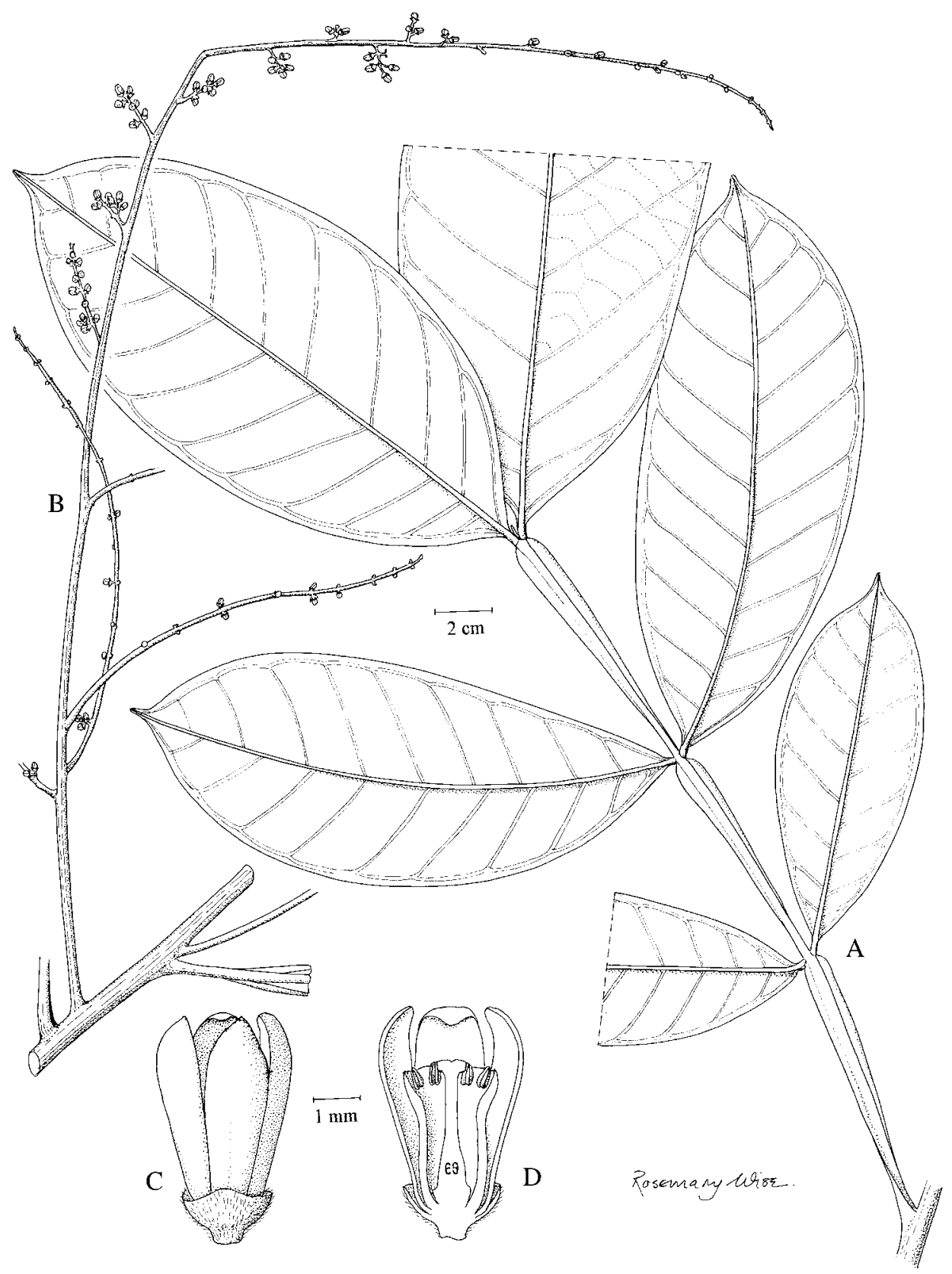

FIG. 10. Guarea pterorhachis Harms subsp. submarginalis T.D.Penn. A, leaf; B, inflorescence; C, flower; D, half-flower. (A, Gentry et al. 53365; B-D, Juncosa 1717).

Young shoots minutely appressed puberulous to tomentose, stout, c. $1 \mathrm{~cm}$ diam., and often hollow, eventually scaling and suberous, scales c. $2-3 \times 0.5 \mathrm{~mm}$. Leaves pinnate with a terminal bud with intermittent growth, petiole $20-25 \mathrm{~cm}$ long, channelled at 


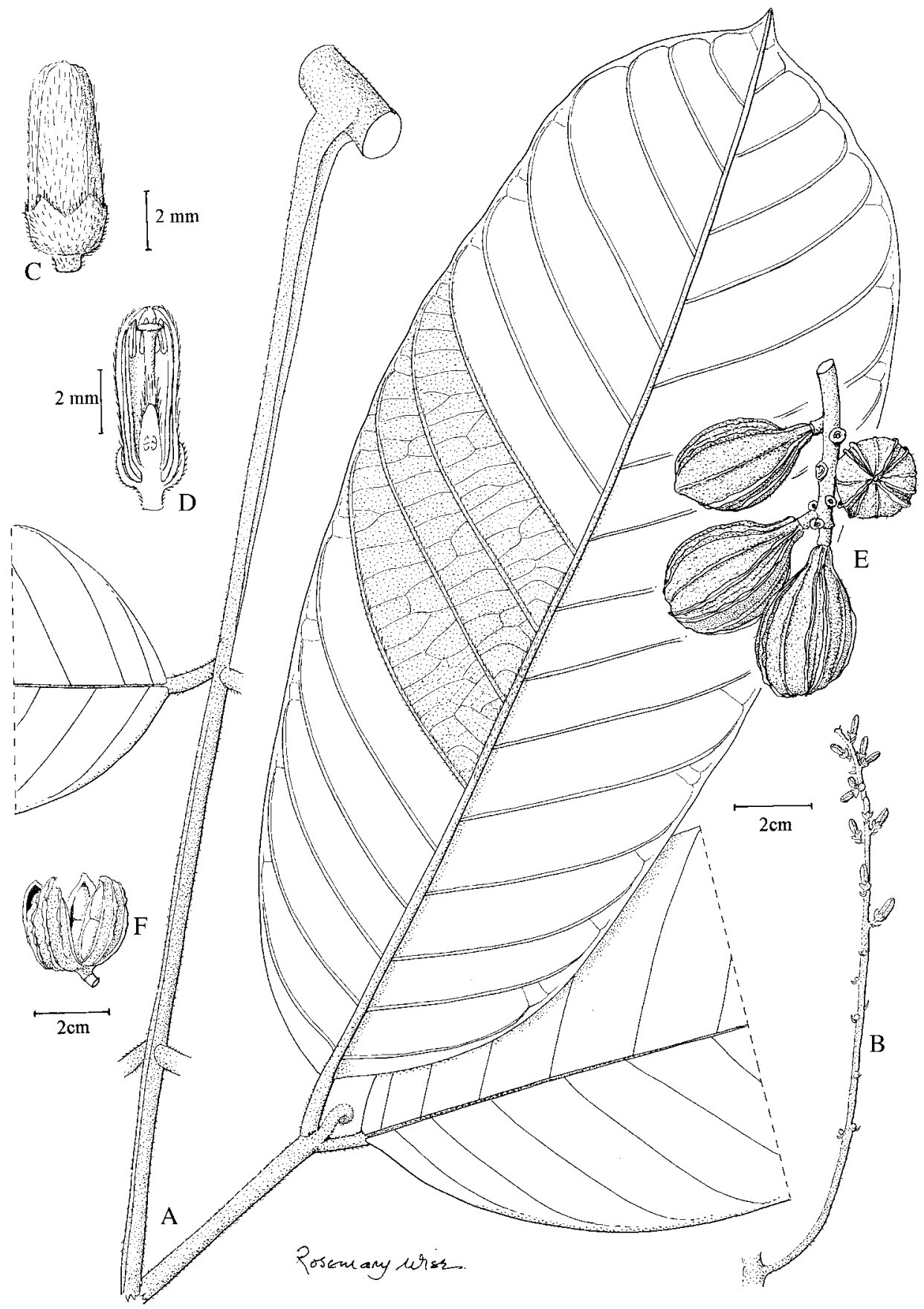

FIG. 11. Guarea caulobotrys Cuatrec. A, leaf; B, inflorescence; C, flower bud; D, half-flower; E, infructescence; F, dehisced fruit. (A, E, Monsalve 1673; B-D, McPherson 11866; F, Juncosa 1233). 
the base to semiterete at the apex, pubescent to tomentose, rhachis up to $70 \mathrm{~cm}$ long, terete, pubescent to tomentose; petiolule swollen, 1-10 $\mathrm{mm}$ long, pubescent to tomentose. Leaflets opposite, 3-5 pairs, 28-46.5 $\times 8.9-17.5 \mathrm{~cm}$, broadly oblong to broadly elliptic, apex acute to acuminate or obtusely cuspidate, base acute to obtuse or truncate, chartaceous to coriaceous, upper surface glabrous or with residual indumentum on the midrib, lower surface pale tomentose on midrib and veins, sparsely soft pubescent on the lamina, or eventually glabrous, minute raised dots usually visible on upper surface $(\times 10)$, not glandular-punctate or -striate; venation mostly eucamptodromous, sometimes brochidodromous towards the apex, midrib sunken on the upper surface, secondaries 16-21 pairs, ascending, straight and parallel, intersecondaries short or absent, tertiaries oblique, sometimes prominent below. Inflorescence cauliflorous, 5-25 cm long, a raceme or slender panicle with a few short lateral branches and thyrsoid flower clusters, flower clusters subtended by a short lanceolate bract c. $2 \mathrm{~mm}$ long, pubescent to tomentose; pedicel c. $1 \mathrm{~mm}$ long. Calyx patelliform to cyathiform, 1.5-2.5 mm long, 4-lobed to halfway or more, the lobes broadly ovate and often obtusely cuspidate at the apex, sparsely pubescent outside, glabrous inside. Petals 4, c. $12 \times 2 \mathrm{~mm}$, strap-shaped, apex acute, free, valvate, sericeous outside, glabrous inside. Staminal tube c. $9 \mathrm{~mm}$ long, c. $3 \mathrm{~mm}$ broad, margin undulate, glabrous; anthers 8-9, c. $1.5 \mathrm{~mm}$ long, narrowly oblong, dehiscent, glabrous. Nectary c. $2 \mathrm{~mm}$ long, a stout stipe expanded into a collar below the ovary, glabrous. Ovary ovoid, c.3 $\mathrm{mm}$ long, 4-locular, locules with 2 superposed ovules, densely strigose, style c. $2 \mathrm{~mm}$ long, style-head discoid. Capsule $2.5-4 \mathrm{~cm}$ long, $1.7-2.5 \mathrm{~cm}$ broad, ovoid, obovoid or pyriform, apex rounded, base obtuse, 4-valved, each valve with 3 irregular thick, longitudinal, torulose ribs, tending to anastomose at the apex, ribs $2-3 \mathrm{~mm}$ high, pericarp $3-4 \mathrm{~mm}$ thick (without the ribs), minutely puberulous to shortly tomentose, indumentum intermixed with sparser longer hairs, valves with 2 superposed seeds and not constricted between the seeds. Seeds c.10 $\times 6 \mathrm{~mm}$, planoconvex, completely surrounded by a thin fleshy sarcotesta. Seed coat thin and fleshy.

Field characters. Unbranched or sparsely branched treelet to $8 \mathrm{~m}$ high and $12 \mathrm{~cm}$ diam.; bark reddish brown, scaling and slightly suberous; with a terminal cluster of leaves up to $1 \mathrm{~m}$ long; cauliflorous with creamish white flowers; and the fruit maturing dark red. Flowering recorded in December and January, fruiting in April and October.

Distribution and ecology. Pacific coast of Colombia (Choco, Nariño and Valle) to Panama (provinces of Panamá and San Blas) in wet lowland rain forest up to $350 \mathrm{~m}$ altitude.

Collections examined. Panama. Panamá: El Llano-Carti road $20 \mathrm{~km} \mathrm{~N}$ of turnoff (NW0978), Churchill 3826 (MO). San Blas: El Llano-Carti road, $16.5 \mathrm{~km} \mathrm{~N}$ of Panamerican highway (NW0978), Folsom 2612 (MO); San Blas-Panamá border on Kuna divide trail (NW0979), McPherson 11866 (MO); San Blas boundary trail on El Llano-Carti road (NW0979), McPherson \& Merello 8184 (K); Continental divide trail to W from El Llano-Carti road (NW0978), Nevers \& Herrera 4474 (MO). 
Colombia. Chocó: Municipio Istmina, Alto Rio San Juan (NW0576), Espina et al. 1399 (K, MO); Tutunendo to Icho (NW0576), Juncosa 1233 (K, MO). Nariño: Municipio de Mosquera, quebrada La Barrera (NW0278), Romero-Castañeda 5519 (COL). Valle: R. Yurumangui (NW0377), Cuatrecasas 15739 (F); Bajo Calima Concession, $16 \mathrm{~km} \mathrm{~N}$ of Buenaventura (NW0377), Faber-Langendoen et al. 224 (K); Concesión Pulpapel/Buenaventura (NW0377), Monsalve 1673 (MO).

This species is morphologically close to Guarea fistulosa (Amazonian drainage of Colombia, Ecuador and Peru and Panama). The species share similar vegetative structure of stems and leaves, including the hollow twigs, and their flowers and fruit are also very similar in size and number of parts. The only differences we can find are the scaly twigs of Guarea caulobotrys (smooth in G. fistulosa), presence of minutely raised dots on the upper leaf surface of Guarea caulobotrys (absent in G. fistulosa), and a slight difference in the thickness of the fruit ribs. However, this close morphological similarity is not reflected in the ITS phylogeny which indicates that it occupies a basal position, sister to the rest of the South American clade, whereas Guarea fistulosa is remote from it on one of the ultimate branches.

\section{Guarea zepivae T.D.Penn., sp. nov. Figs 12, $51 B$.}

Guarea gracili affinis sed petiolo longiore, nervis secundariis 12-13, foliolis pubescentibus, capsula laevi differt. - Type: Brazil, Mato Grosso, Municipio Novo Mundo, Parque Estadual Cristalino, fl., Sasaki, Biggs, Silveira, Philippsen \& Bessa 2089 (holo SPF n.v.; iso K).

Young shoots softly pubescent, 5-7 $\mathrm{mm}$ diam., smooth, indumentum persistent. Leaves pinnate with a non-active terminal bud, petiole $10-13.5 \mathrm{~cm}$ long, semiterete, softly pubescent, indumentum persistent, rhachis $12.5-25 \mathrm{~cm}$ long, semiterete and slightly channelled above to terete at the apex, softly pubescent; petiolule 5-7 mm long, pubescent. Leaflets 4-5 pairs, opposite, 17.5-25.5 $\times 5-8.3 \mathrm{~cm}$, elliptic or oblanceolate, apex acuminate, base acute or narrowly attenuate, chartaceous, upper surface shortly pubescent on midrib and secondary veins and with scattered pubescence on the lamina, not glandular-punctate or -striate, leaves drying pale green; venation eucamptodromous, midrib slightly sunken on the upper surface, secondaries 12-13 pairs, steeply ascending, slightly arcuate and slightly convergent, intersecondaries short or absent, tertiaries oblique, obscure. Inflorescence on twigs below the leaves, $2-5 \mathrm{~cm}$ long, a small panicle with short lateral branches to 3-4 mm long, pubescent; pedicel 1-1.5 mm long, pubescent. Flowers subtended by a small bract $0.5-1 \mathrm{~mm}$ long. Calyx c. $2.5 \mathrm{~mm}$ long, cup-shaped, shallowly and irregularly lobed to $1 / 4$ its length, sparsely pubescent outside, glabrous inside. Petals 4, 7.5-8 mm long, 1-1.5 mm broad, strapshaped, apex acute, densely appressed pubescent outside (pale whitish hairs), glabrous inside. Staminal tube c. $6.5 \times 2 \mathrm{~mm}$, cylindrical, margin undulate to shortly lobed, glabrous; anthers 8 , c.1 mm long, glabrous. Nectary a stout stipe c.1 mm long, expanded below the ovary, glabrous. Ovary c. $2 \mathrm{~mm}$ long, ovoid, 4-locular, locules with 1 ovule, sparsely strigose, style 3-3.5 mm long, glabrous, style-head discoid, slightly 


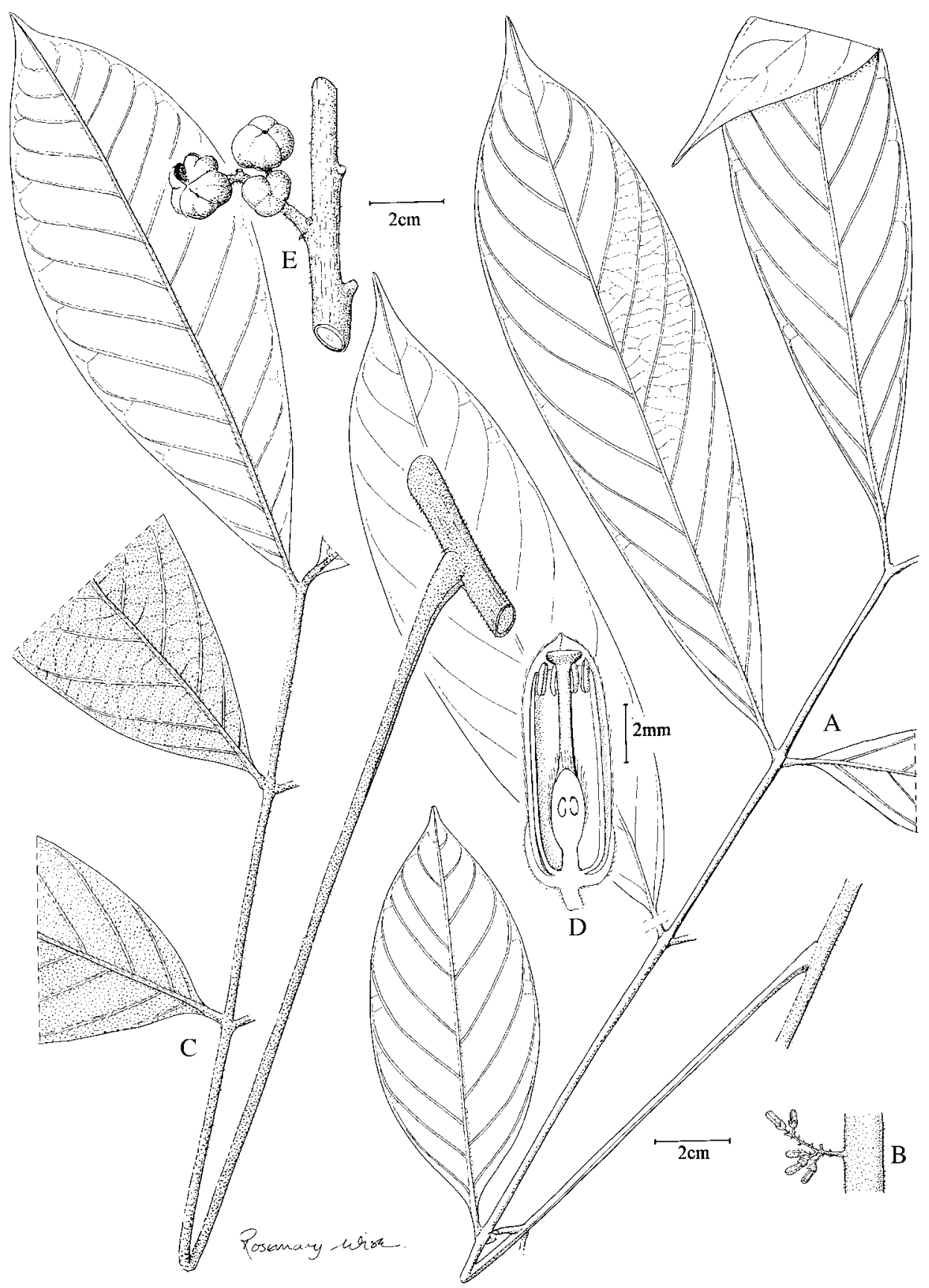

FIG. 12. Guarea zepivae T.D.Penn. A, leaf; B, inflorescence; C, leaf with indumentum on lower surface; D, half-flower; E, fruit. (A, B, D, Sasaki et al. 2089; C, E, Sasaki et al. 1737). 
exceeding the anthers. Capsule $1.1-1.3 \mathrm{~cm}$ long, $1.2-1.5 \mathrm{~cm}$ broad, oblate to globose, apex truncate, base truncate or obtuse, (3-)4-valved, valves 1-seeded, smooth, sparsely and coarsely pubescent at first, glabrous at maturity, pericarp c.1 mm thick. Seed 8 $9 \mathrm{~mm}$ long, shaped like the segment of an orange, surrounded by a thin oily sarcotesta.

Field characters. Treelet to $6 \mathrm{~m}$ high, with whitish flowers and red fruit. Flowering recorded in February, fruit maturing in June.

Distribution and ecology. An understorey treelet in transitional seasonal forest with an open canopy 10-20 m high, and emergents to $35 \mathrm{~m}$ high, over non-flooded sandy land, below $300 \mathrm{~m}$ altitude. At present known only from the Parque Estadual Cristalino, Mato Grosso, Brazil.

Collections examined. Brazil. Mato Grosso: Municipio de Novo Mundo, Parque Estadual Cristalino (SW0955), Sasaki et al. 1670 (K), 1737 (K).

Guarea zepivae is morphologically closest to two other southeast Brazilian species, $G$. gracilis and $G$. pendula, and all share similar small flowers with 4 petals, 8 stamens, 4-locular ovary with uniovulate locules, and small 4-valved capsule. Guarea zepivae differs from G. gracilis in the following characters: petiole $10-13 \mathrm{~cm}$ long (2$4 \mathrm{~cm}$ long in $G$. gracilis), leaflets $17.5-25.5 \mathrm{~cm}$ long (9-13.5 cm long in G. gracilis), secondary veins $12-13$ pairs (6-8 pairs in G. gracilis), leaflets pubescent (subglabrous in $G$. gracilis), capsule smooth (capsule prominently ribbed in G. gracilis). Guarea pendula has leaflets bearing numerous minute red papillae on the lower surface, whereas these are absent in G. zepivae. It also differs in having fewer secondary veins and in its pyriform costate capsule.

The morphological resemblance is not reflected in the ITS phylogeny which shows Guarea zepivae to be embedded with other Amazonian species, whereas G. gracilis and $G$. pendula are embedded in a small group of coastal Brazilian species.

This species is named after José (Zé) H. Piva, field technician with the Kew Cristalino Project, skilled plant identifier and self-taught botanist, co-author of Vegetação e Plantas do Cristalino (Sasaki et al., 2010).

15. Guarea sprucei C.DC. in Mart., Fl. Bras. 11(1): 196, t. 58 (1878); T.D.Penn. in T.D.Penn. et al., Fl. Neotrop. 28: 334 (1981). - Type: Brazil, Amazonas, R. Negro, near São Gabriel da Cachoeira [SW0067], fl., Spruce 2240 (holo G-DC; iso BM, K, M, NY, OXF, P). Figs 13, 48B.

Young shoots densely golden-tomentose to villose, massive, $2-3 \mathrm{~cm}$ diam., soon developing a strongly suberous, fissured bark 5-10 $\mathrm{mm}$ thick. Leaves pinnate with a terminal bud showing indeterminate growth, petiole 5-10 cm long, channelled and slightly winged at the base to semiterete at the apex, tomentose, rhachis up to $80 \mathrm{~cm}$ long, semiterete, tomentose; petiolule very short, tomentose. Leaflets opposite, 3-8 pairs, 30-38 $\times 11-14 \mathrm{~cm}$, lower ones much smaller, broadly oblong, apex acute to obtusely cuspidate, base truncate to slightly cordate, coriaceous and strongly bullate, 


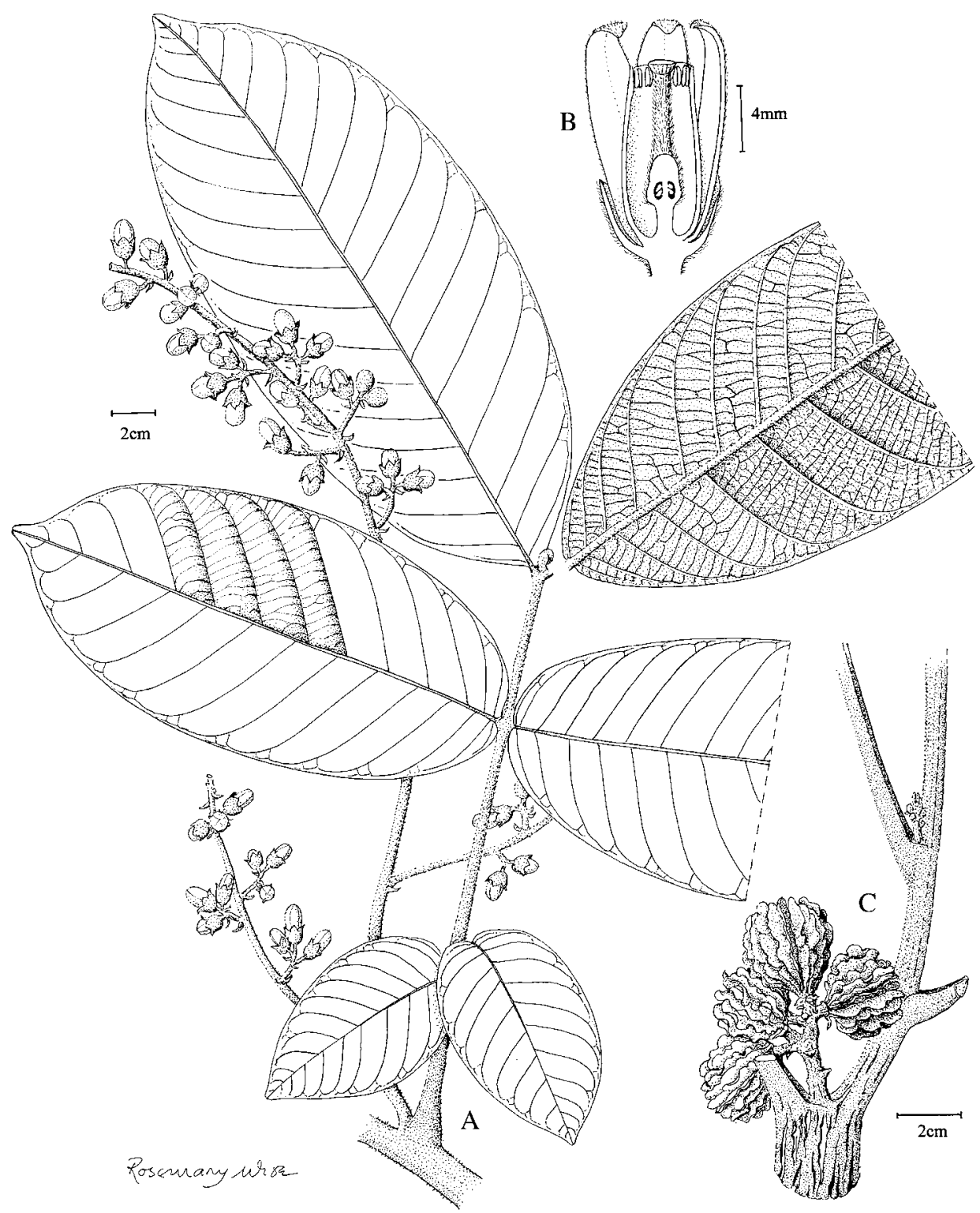

FIG. 13. Guarea sprucei C.DC. A, habit; B, half-flower; C, infructescence. (A, B, Spruce 2240; C, Cid et al. 1567).

upper surface with tomentose midrib and veins at first, becoming glabrous, lower surface with tomentose to villose midrib and veins, and pubescent lamina, hairs intermixed with minute red papillae, not glandular-punctate or -striate; venation eucamptodromous, midrib sunken on the upper surface, secondaries 18-23 pairs, shallowly ascending, parallel, straight or slightly arcuate, lowermost secondaries 
often slightly divergent, intersecondaries very short, tertiaries oblique, parallel, sunken on the upper surface, raised strongly on the lower surface; higher order reticulum prominent on the lower surface. Inflorescence axillary or on twigs below the leaves, $15-30 \mathrm{~cm}$ long, a laxly-branched panicle, the lowest lateral branches to $12 \mathrm{~cm}$ long, golden-tomentose, flower clusters subtended by small lanceolate bracts 2-3 mm long; pedicel 1-1.5 mm long. Calyx 6-7 mm long, cyathiform, irregularly 3-5-lobed, golden-tomentose. Petals 5, valvate, $14-15 \mathrm{~mm}$ long, 3.5-4.5 mm broad, oblong, apex acute, golden-sericeous outside, glabrous inside. Staminal tube slightly narrowed at the throat, 11-12 $\mathrm{mm}$ long, 3-4 mm broad, margin undulate, glabrous; anthers $10-11$, c. $1.8 \mathrm{~mm}$ long. Nectary a stout stipe expanded at the apex to form a ring below the ovary, c. $2.5 \mathrm{~mm}$ long, glabrous. Ovary strongly longitudinally ribbed, 6-8-locular, locules with 2 superposed ovules, densely strigose, style stout, strigose, style-head discoid. Capsule 3.5-4 cm long and broad, obovoid, apex truncate, base obtuse, 6-8-valved, each valve with 3 longitudinal convoluted and anastomosing ribs or wings to $6 \mathrm{~mm}$ deep, golden-velutinous, valves with 1-2 superposed seeds, pericarp 2-3 mm thick (excluding the wings); immature seeds only.

Field characters. A slender tree to $30 \mathrm{~m}$ high, with whitish flowers. Flowering is recorded in March and October, with mature fruit in July.

Distribution and ecology. Upper Rio Negro, Amazonas and along the Rio Trombetas in Pará, Brazil in lowland non-flooded rain forest.

Collections examined. Brazil. Amazonas: Rio Negro, São Gabriel da Cachoeira, above confluence with R. Uaupés (NW0067), Daly et al. 5452 (K, NY). Pará: Municipio Oriximiná, R. Trombetas, Lago Erepeçu (SW0156), Cid et al. 1567 (K, NY, US): Municipio Oriximiná, R. Trombetas, Lago Mucura (SW0155), Cid et al. 1750 (K, NY, US); Municipio Oriximina, R. Trombetas, Porto Trombetas (SW0156), Cid et al. 1962 (NY).

The Pará collections are included in this species with some reservations as they differ from those of the type locality in some minor characters such as the slightly longer petiolules and the slightly shorter indumentum. However, at this time, with so few collections available, there is no justification for regarding them as specifically distinct.

The ITS phylogeny places this species with two other large-flowered species with prominently ribbed or winged capsules (Guarea carinata and G. cristata).

16. Guarea carinata Ducke, Trop. Woods 76: 16 (1943); T.D.Penn. in T.D.Penn. et al., Fl. Neotrop. 28: 342, fig. 72 (1981). - Type: Brazil, Amazonas, Esperança (mouth of R. Javarí), fr., Ducke 1060 (holo RB; iso K, MG, NY, US). Fig. 48C.

Abbreviated description. Young shoots and inflorescences densely golden tomentose, twigs becoming suberous and fissured, leaves with a terminal bud showing intermittent growth, leaflets up to $7(-10)$ pairs, $14-27 \times 4.5-10(-12) \mathrm{cm}$, usually oblong, less frequently elliptic or oblanceolate, chartaceous to thinly coriaceous, 
upper surface with pubescent midrib, lower surface coarsely pubescent, denser on the veins, secondary veins (14-)16-20 pairs, inflorescence axillary or in the axils of fallen leaves, 2-10 cm long, unbranched or with short lateral branches, flowers in small sessile clusters, subtended by short bracts, petals 4(-5), valvate, 14-17 mm long, densely golden strigose, staminal tube 11-13 mm long, 3-4(-5) $\mathrm{mm}$ broad, anthers 8-11, ovary (4-)5-6(-9)-locular, locules with 2 superposed ovules, capsule 3-4.8 cm long, 3-4.2 cm broad, usually pyriform, rarely depressed-globose, 5-6(-9)-valved, valves shallowly to prominently 3 -ribbed, the central ribs often larger and branching and anastomosing above, tomentose or pubescent with age, pericarp 4-6 mm thick, valves with 2 superposed seeds.

Distribution and ecology. Amazonian Ecuador, Peru and Brazil, Guyana, Surinam, not yet recorded from Amazonian Colombia, but almost certainly present there. In non-flooded lowland and lower montane rain forest, up to $1000 \mathrm{~m}$ altitude in Ecuador.

Additional collections examined. Guyana. Bartica-Potaro 107 miles, Potaro River, Mahdia (NW0559), FDBG 3807 (F 1071) (K).

Ecuador. Napo: Tena Cantón, Jatun Sacha Biological Station (SW0177), Palacios et al. 10441 (MO), Zuleta 10 (K); Loreto, slopes of Volcán Sumaco (SW0077), Freire \& Cerda 149 (K).

Peru. Loreto: Alto Amazonas, Andoas (SW0276), Gentry et al. 29714 (K); Prov. Requena, Jenaro-Herrera (SW0473), van der Werff et al. 10023 (K).

Brazil. Acre: Upper R. Moa, near Fazenda Arizona (SW0773), Campbell et al. 6588 (K), Reserva INCRA Santa Luzia (SW0772), Campbell et al. 6808 (K), 7243 (K), 7478 (K), 7663 (K). Amazonas: Municipio de Novo Aripuana, BR 230, 400 km from Humaita (SW0760), Cid Ferreira 5974 (K, NY); Distrito Agropecuario, Reserva 1501 (km 41), (SW0259), Mori et al. 21325 (US); Municipio de Manaus, BR 174, km 64 (SW0259), Nee 42702 (K), 42759 (NY, US); Distrito Agropecuario, $90 \mathrm{~km}$ NNE of Manaus (SW0259), Oliveira et al. 465 (NY). Mato Grosso: Municipio Novo Aripuana, Rod. do Estanha km 120 (SW0961), Cid Ferreira 5670 (K). Rondonia: Porto Velho, Represa Samuel (SW0963), Thomas et al. 4973 (NY), 4987 (K).

The Guyana collection ( $F D B G 3807$ ) is included with reservations, due to the lack of fruit, and the coarser, more hispid indumentum and strongly impressed midrib and secondary veins. The floral structure agrees with that of Guarea carinata.

17. Guarea cristata T.D.Penn. in T.D.Penn. et al., Fl. Neotrop. 28: 329, fig. 69 (1981). - Type: Brazil, Amazonas 180 miles up R. Javarí from Tabatinga, fl., Pennington, Prance, Hill \& Ramos 10074 (holo INPA; iso FHO, NY). Fig. 53A.

Abbreviated description. Young shoots and inflorescences densely golden hirsute or villose, leaves with indeterminate apical growth, leaflets up to 7 pairs, $15-29 \times 3.8$ $8 \mathrm{~cm}$, oblanceolate, chartaceous, lower surface coarsely hirsute, venation usually brochidodromous, secondary veins $13-18$ pairs, inflorescence axillary, 2-5 cm long, a densely-flowered, congested thyrse or raceme, petals 4, valvate, 16-17 mm long, densely golden-sericeous, staminal tube 14-15 $\mathrm{mm}$ long, 5-7 $\mathrm{mm}$ broad, anthers 8-11, ovary 4-6-locular, locules with 2 superposed ovules, capsule tardily dehiscent, 4-6 cm diam., \pm globose, with dense fleshy convoluted longitudinal wings, (12 larger wings 
10-15 $\mathrm{mm}$ deep, 12-20 lesser wings up to $5 \mathrm{~mm}$ deep) 4-6-valved, each valve with 2 superposed seeds, pericarp 2-3 mm thick (excluding the wings), coarsely pubescent.

Distribution and ecology. Amazonian Colombia, Ecuador, Peru and extreme western Amazonian Brazil, mostly recorded from lowland rain forest over infertile white sand, or occasionally on red clays.

Additional collections examined. Colombia. Amazonas: Municipio de Leticia, Tarapaca, Amacayacu National Park (SW0370), Rudas et al. 2409 (MO). Caquetá: Araracuara (SW0072), Duivenvoorden et al. 2766 (K), Gentry \& Sanchez 64987 (K).

EcuAdor. Pastaza: Loroacachi (SW0175), Brandbyge \& Azanza 30688 (AAU), Jaramillo et al. 31111 (AAU), 31374 (AAU).

Peru. Madre de Dios: Tambopata, Parque Nacional Bahuaja-Sonene (SW1268), Diaz \& Ramirez 9565 (QCNE). Loreto: Maynas, Quebrada Blanca Biological Station (SW0373), Castro 1 (K); Maynas, Mishana, R. Nanay (SW0373), Gentry \& Emmons 38771 (K), Gentry et al. 31685 (NY); Constancia, Quebrada Tamshiyacu (SW0472), Gentry et al. 76441 (K); Allpahuayo Biological Station (SW0373), Jaramillo \& Marcos 694 (K, MO); Requena, Jenaro Herrera (SW0473), Spichiger \& Encarnacion 1192 (G, NY); Maynas, Puerto Almendras (SW0373), Vásquez \& Jaramillo 4609 (K); Iquitos, Allpahuayo (SW0473), Vásquez \& Jaramillo 16629 (MO); Maynas, Puerto Almendras (SW0373), van der Werff et al. 9837 (K); Requena, Jenaro Herrera (SW0473), van der Werff et al. 10124 (K).

18. Guarea cinnamomea Harms, Notizbl. Bot. Gart. Berlin-Dahlem 13: 504 (1937);

T.D.Penn. in T.D.Penn. et al., Fl. Neotrop. 28: 307, fig. 62 (1981). - Type: Brazil, Amazonas, Paranagua, f1., Krukoff 4556 (holo B, destroyed; lecto K; isolecto A, G, NY, U). Figs 14, 48D.

Guarea quadrangularis M.E.Morales, Rev. Acad. Colomb. Cienc. 22: 336 (1998), syn.

nov. - Type: Colombia, Vaupés, Caparu Biological Station, $3 \mathrm{~km} \mathrm{~N}$ of Lake Taraira, fl., Defler 291 (holo COAH).

Abbreviated description. Young shoots and inflorescences puberulous, leaves with a terminal bud showing intermittent growth, leaflets up to 11 pairs, $(11.2-) 15-35(-45) \times(5.3-) 7-11.5(-12.9) \mathrm{cm}$, usually broadly oblong, sometimes narrowly elliptic or ovate, coriaceous, glabrous above, minutely puberulous on midrib and veins below, with numerous red papillae on the lamina, secondary veins 12-17 pairs, inflorescence axillary or on twigs below the leaves, $3-15 \mathrm{~cm}$ long, a raceme or thyrse with lateral branches to $6 \mathrm{~cm}$ long, petals 4-5, valvate, $11.5-14 \mathrm{~cm}$ long, staminal tube 9-10 mm long, c. $3 \mathrm{~mm}$ broad, anthers 7-9, 1.5-2 $\mathrm{mm}$ long, ovary 4-6-locular, locules 1-ovulate, capsule 5-6.2 cm long, ovoid or broadly pyriform, apex rounded or apiculate, tapering gradually to a short stout stipe, 4-6-valved, valves smooth or faintly 5-8-ribbed, puberulous or papillose, pericarp 4-7 mm thick, valves 1 -seeded.

Distribution and ecology. Central and western Amazonian Brazil, Colombia and Peru, and with a single record from French Guiana, in lowland non-flooded rain forest. 


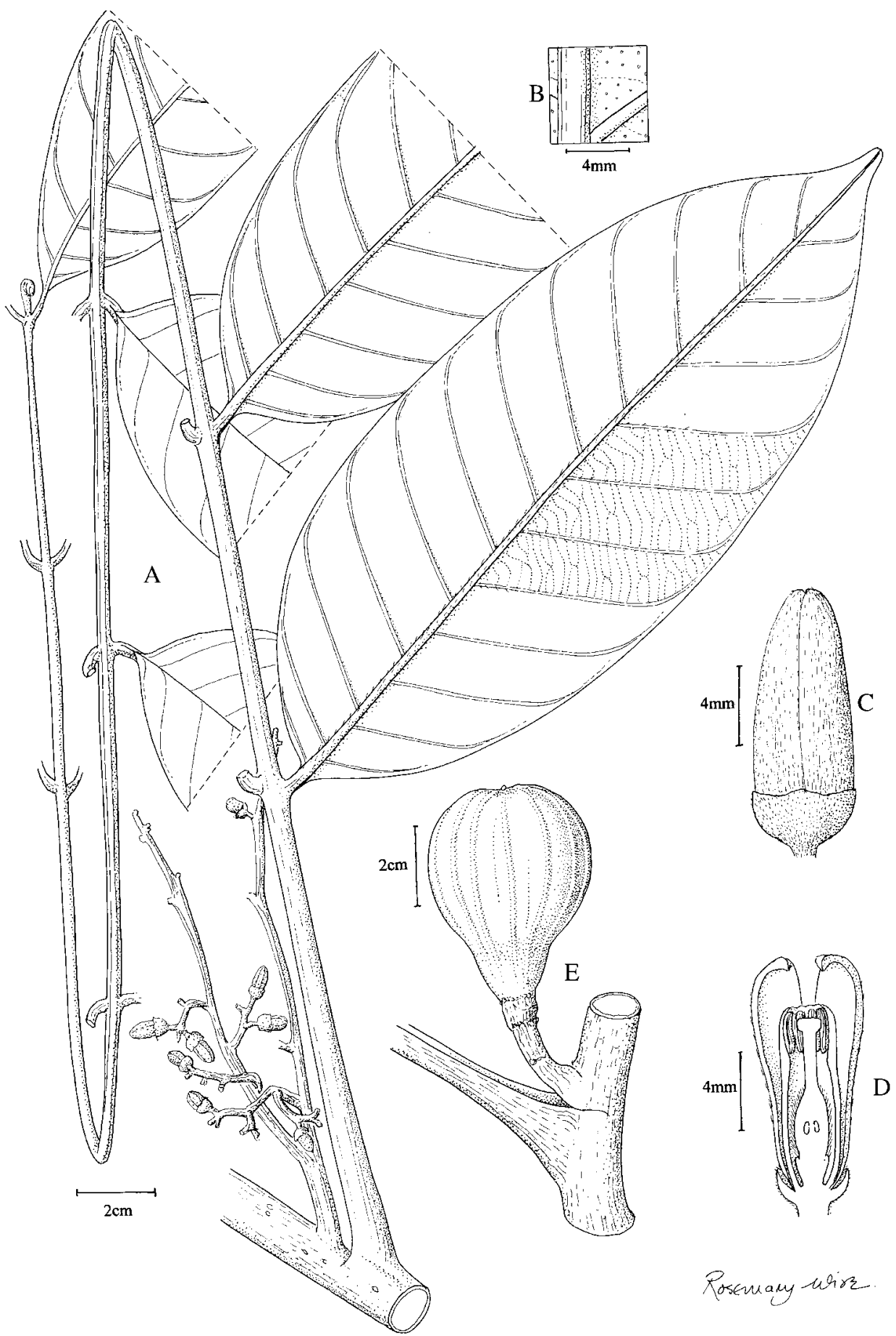

FIG. 14. Guarea cinnamomea Harms. A, habit; B, enlargement of leaf undersurface; C, flower bud; D, half-flower; E, fruit. (A-D, Daly et al. 4179; E, Thomas et al. 5362). 
Additional collections examined. French Guiana. Fleure Approuague, Rivière Matarony, Saut Magasin (NW0451), Oldeman B1017 (K, U).

Colombia. Vaupés: Caparú Biol. St., N of Lake Taraira (SW0169), Defler 291 (COAH).

Peru. Amazonas: Condorcanqui Province, El Cenepa, Tutino (SW0478), Vásquez et al. 24209 (F). Loreto: Requena, Jenaro Herrera (SW0473), Collector unknown (Fig. 2-1/85) (K, MOL); Pennington et al. 17417 (K, MOL).

Brazil. Amazonas: Municipio Jutai, Jutai (SW0266), Daly et al. 4179 (K, NY); Presidente Figueiredo, R. Uatuma, Represa de Balbina (SW0159), Thomas et al. 5362 (K, NY). Pará: Municipio Oriximina, R. Mapuera, Tres Ilhas (SW0157), Cid Ferreira 9693 (K).

19. Guarea michel-moddei T.D.Penn. \& S.A.Mori, Brittonia 45(3): 231, figs 1, 2 (1993). - Type: French Guiana, Saül, La Fumée Mountain trail, fl., Mori, Gracie, Angell \& Rothman 20963 (holo NY; iso CAY, K). Fig. 48E.

Young shoots golden tomentose to villose at first, soon becoming glabrous and strongly suberous and fissured, $1-1.5 \mathrm{~cm}$ diam. Leaves pinnate with a terminal bud showing intermittent growth, petiole $8-17 \mathrm{~cm}$ long, semiterete to channelled on the upper surface, sparsely hirsute, rhachis $20-60 \mathrm{~cm}$ long, semiterete to channelled, sparsely hirsute; petiolule 3-7 mm long. Leaflets opposite, 3-10 pairs, 20-41 $\times 5-$ $11 \mathrm{~cm}$, oblong, apex obtuse, obtusely cuspidate to narrowly attenuate, base acute to obtuse, coriaceous, upper surface glabrous, lower surface with sparse hirsute indumentum on midrib and veins, sometimes glandular-punctate or -striate; venation eucamptodromous or brochidodromous in the upper half, midrib and secondary veins sunken on the upper surface, secondaries 15-18 pairs, ascending, straight or slightly arcuate, parallel or slightly convergent, intersecondaries short or absent, tertiaries oblique, all orders of venation strongly impressed on the upper surface and prominent below (bullate). Inflorescence cauliflorous, to $1 \mathrm{~cm}$ long, a few-flowered congested thyrse, sparsely pubescent, pedicel c.1 mm long. Calyx 2-3 mm long, cyathiform, irregularly 4-lobed, the lobes c. $1.5 \mathrm{~mm}$ long, sparsely puberulous outside. Petals 4, valvate, c. $1.3 \mathrm{~cm}$ long, c. $3.5 \mathrm{~mm}$ broad, strap-shaped, apex acute, shortly appressed pubescent outside, glabrous inside, reflexing with age. Staminal tube c.9.5 mm long, c. $4 \mathrm{~mm}$ broad, margin undulate, glabrous; anthers 8 , c. $1.5 \mathrm{~mm}$ long, glabrous. Nectary a broad stipe c. $1 \mathrm{~mm}$ long, expanded to form a collar below the ovary, glabrous. Ovary 6-8-locular, locules with 2 superposed ovules, densely strigose, style glabrous, stylehead discoid. Capsule 3-4 cm long, globose or depressed-globose, 6-8-valved, the valves with several anastomosing and convoluted fleshy ribs or wings up to $1 \mathrm{~cm}$ deep, sparsely hirsute, pericarp 2-4 mm thick (excluding the wings), valves with 2 superposed seeds. Seeds $1.3-1.5 \mathrm{~cm}$ long, c.1 cm broad, surrounded by a fleshy orange sarcotesta.

Field characters. Unbranched treelet to $5 \mathrm{~m}$ high, with deeply fissured and scaling suberous bark, with a large terminal cluster of spirally arranged strongly bullate leaves. The flowers are cream-coloured and the capsule bright red and covered with convoluted fleshy wings and ribs; the fruit is only tardily dehiscent. Flowering in September (only one collection seen) and mature fruit recorded in January, February, April, May and August. 
Distribution and ecology. Known only from French Guiana and adjacent Brazil, where it occurs in the understorey on steep slopes and ridges in lowland rain forest up to $600 \mathrm{~m}$ altitude.

Collections examined. French Guiana. Camp Caiman - Asarco - Mt. de Kaw (NW0452), Bordenave \& Raes 5256 (CAY); Savane Roche de Virginie, bassin de l'Approuague (NW0452), Cremers \& Petronelli 11868 (CAY, K); route Region - Saint Georges (NW0452), Cremers \& Gautier 11959 (K, US); Montagne de Kaw (NW0452), Delnatte 1615 (CAY); 50 km SE of Saül (NW0354), de Granville 3505 (CAY); Station des Nouragues (NW0452), de Granville et al. 11170 (CAY, K, NY); Montagne Bellevue de l'Inini (NW0553), de Granville et al. 7749 (CAY, K); Mont Galbao (NW0353), de Granville et al. 8821 (CAY), Pennington \& Mori 12100 (K), 12118 (CAY, K); Relais de Patawa (NW0452), Mori et al. 25352 (CAY); Montagne de Kaw (NW0452), Oldeman 2375 (CAY); Station des Nouragues (NW0452), Prévost 2211 (K); R. Arataye, 68 km SW of Regina, Villiers 4030 (CAY).

Brazil. Amapá: Municipio Macapá, Perimetral Norte (BR 210) (NW0153), Daly et al. 4027 (NY).

This species is morphologically close to Guarea cristata (western Amazonia). However, the very large and bullate subglabrous leaflets are very distinctive and unlike the smaller, non-bullate coarsely hirsute leaflets of Guarea cristata. There are also several quantitative floral and fruit differences between them, such as petals c. $1.3 \mathrm{~cm}$ long in Guarea michel-moddei (versus 1.6-1.7 cm in G. cristata), and capsule 3-4 cm long and 6-8-valved in G. michel-moddei (versus capsule 4-6 cm long and 4-6-valved in G. cristata).

20. Guarea subandina W.Palacios, Fl. Ecuador 82, Fam. 98, Meliaceae: 44 (2007). - Type: Ecuador, Zamora-Chinchipe, La Esmeralda, Cooperativa San Francisco de Numbala Alto, fl., Palacios \& Tirado 13112 (holo QCNE; iso MO). Figs 15, 53B.

Young shoots pale tomentose, 7-8 mm diam., eventually becoming glabrous, pale whitish and slightly suberous. Leaves pinnate with a terminal bud showing intermittent growth, petiole 5-10 cm long, semiterete at the base to terete at the apex, tomentose at first, rhachis up to $50 \mathrm{~cm}$ long, slightly channelled above or terete, tomentose to pubescent; petiolule 6-10 mm long. Leaflets up to 5 pairs, $12-22 \times 6-$ $8 \mathrm{~cm}$, elliptic or oblanceolate, apex acuminate to obtusely cuspidate, base acute to narrowly attenuate, thinly coriaceous, upper surface glabrous except for residual pubescence along the midrib, lower surface pale tomentose on midrib and veins, sparsely pubescent on the lamina, not glandular-punctate or -striate; venation eucamptodromous, midrib sunken on the upper surface, secondaries 16-18 pairs, ascending, parallel, slightly arcuate or straight, intersecondaries short or absent, tertiaries oblique, parallel. Inflorescence axillary, 15-20 cm long, racemose, tomentose. Flowers subtended by slender bracts 5-6 mm long; pedicel stout, 1-1.5 mm long. Calyx cyathiform, c. $5 \mathrm{~mm}$ long, with 4 shallow broadly ovate, obtuse lobes, pubescent outside, subglabrous inside. Petals 4, valvate, free, 16-17 mm long, 3-4 mm broad, strap-shaped, apex acute, sericeous outside, glabrous inside. Staminal tube 10-12 mm long, 4-5 mm broad, margin undulate, glabrous; anthers 


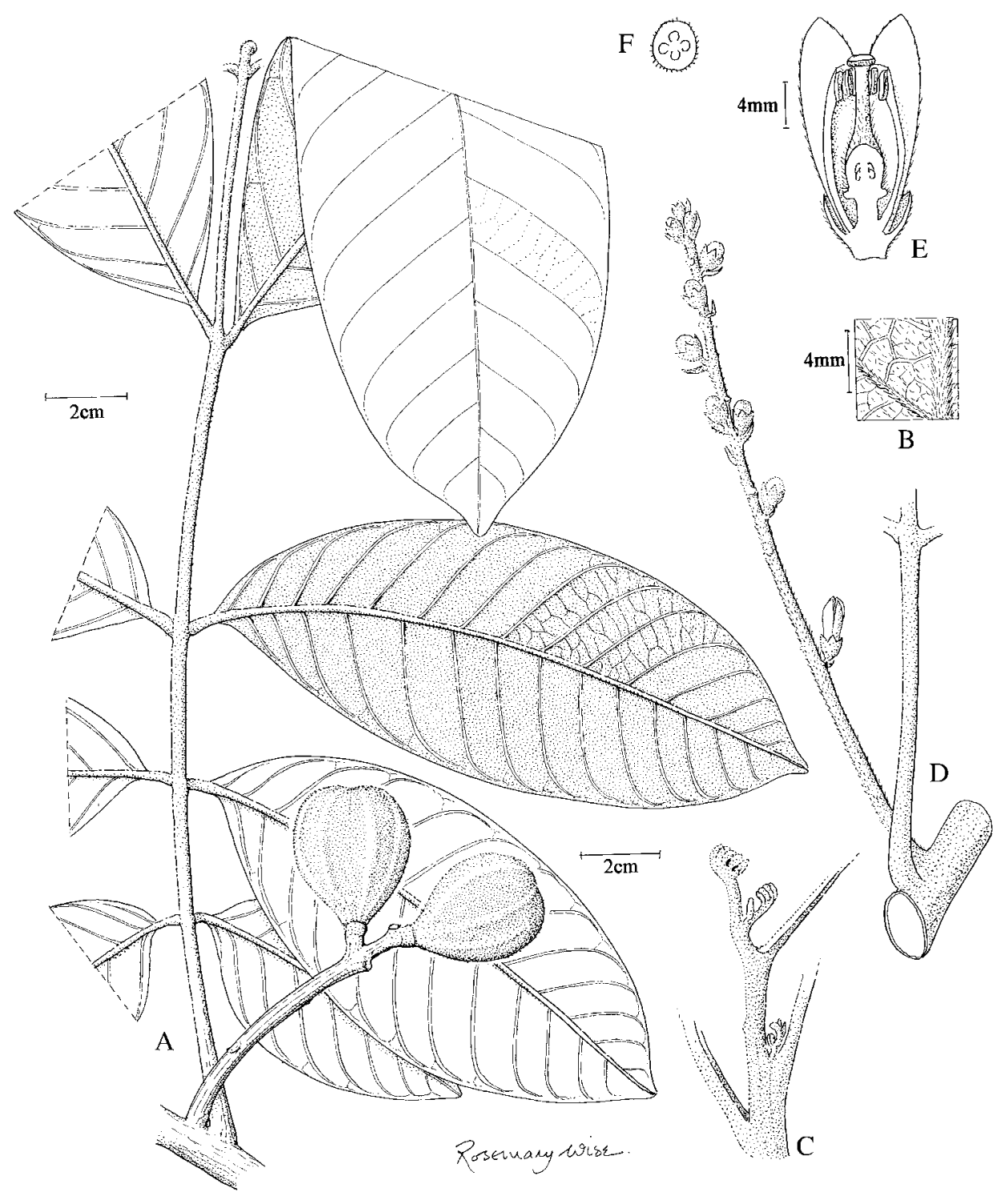

FIG. 15. Guarea subandina W.Palacios. A, habit with fruit; B, enlargement of leaf undersurface; C, shoot apex; D, young inflorescence; E, half-flower; F, cross-section of ovary. (A-C, E, F, Chimbo \& Chamba 34; D, Diaz \& Torres 7780).

8, 1.5-1.7 mm long, oblong, glabrous. Nectary a stout stipe c. $2 \mathrm{~mm}$ long, expanded below the ovary, glabrous. Ovary 4-locular, locules with 2 superposed ovules, densely tomentose, style c. $6 \mathrm{~mm}$ long, tomentose below, glabrous at the apex, stylehead discoid. Capsule (immature) 3-4 cm long, 3-3.5 cm broad, obovoid, apex rounded or truncate, base acute, 4-valved, valves with 2 superposed seeds, valves 
\pm smooth, velutinous mixed with sparser, longer hairs, slightly longitudinally ribbed when dry, pericarp c. $5 \mathrm{~mm}$ thick. Seed immature.

Field characters. Tree to $20 \mathrm{~m}$ high and $25 \mathrm{~cm}$ diam. with whitish flowers and dark reddish brown fruit. Flowering recorded in October and May, immature fruit in May.

Distribution and ecology. Southern Ecuador and northern Peru in wet montane and cloud forest between $2000 \mathrm{~m}$ and $2400 \mathrm{~m}$ altitude.

Collections examined. EcuAdor. Loja: Estación Científica San Francisco (SW0379), Alvarez et al. 2809 (NY). Loja-Zamora-Chinchipe: km 30 Loja-Zamora, Estación Científica San Francisco (SW0379), Chimbo \& Chamba 34 (K, QCNE), 110 (MO, QCNE), Neill et al. 12696 (K). Zamora-Chinchipe: new road Loja-Zamora, Quebrada del Diablo (SW0379), van der Werff \& Palacios $9233(\mathrm{~K})$.

Peru. Cajamarca: San Ignacio Province, Sr. José de Lourdes (SW0578), Diaz \& Torres 7780 (QCNE).

Guarea subandina is morphologically close to G. carinata (lowland Amazonia). They are similar in leaf morphology, indumentum and floral size and structure. The main differences lie in the inflorescence structure (slender raceme 15-20 cm long, probably with indeterminate apical growth versus a short panicle $2-10 \mathrm{~cm}$ long in Guarea carinata) and in the fruit structure (smooth versus prominently ribbed in G. carinata). Guarea subandina occurs in high montane and cloud forest over $2000 \mathrm{~m}$ altitude, whereas $G$. carinata is confined to lowland and lower montane forest.

21. Guarea pubescens (Rich.) A.Juss., Bull. Sci. Nat. Géol. 23: 240 (1830); Mém. Mus. Hist. Nat. 19: 241, 286 (1831); T.D.Penn. in T.D.Penn. et al., Fl. Neotrop. 28: 293 (1981). - Trichilia pubescens Rich., Actes Soc. Hist. Nat. Paris 1: 108 (1792). - Type: Cayenne (French Guiana), fl., Leblond 61 (holo G; iso P (fragment)).

For synonymy see T.D.Penn. in T.D.Penn. et al., Fl. Neotrop. 28: 295-296 (1981).

Abbreviated description. Indumentum of young shoots and inflorescences coarsely pubescent, leaves with indeterminate apical growth, leaflets 2-7 pairs, 9-26 $\times$ $2.8-10(-12) \mathrm{cm}$, elliptic, oblong, oblanceolate or lanceolate, lower surface pubescent or glabrous, secondary veins $8-12(-15)$ pairs, tertiary veins oblique, usually numerous, straight and closely parallel, inflorescence $2-15(-30) \mathrm{cm}$ long, a fewflowered slender raceme or thyrse, petals (3-)4(-5), valvate, 7-9(-12) $\mathrm{mm}$ long, staminal tube 5-7(-9) $\mathrm{mm}$ long, 1.5-3 mm broad, anthers (7-)8(-9), ovary 4(-5)locular, locules 1-ovulate, densely long-strigose, capsule 1.2-2 cm long, depressed globose or globose, 4-valved, valves obscurely 3(-4)-ribbed and often minutely tuberculate between the ribs, pericarp 0.5-1.5(-2) mm thick, puberulous intermixed with coarser hairs, valves 1 -seeded. 
Key to the subspecies of Guarea pubescens

1a. Leaves usually broadly elliptic or oblanceolate, often less than 3 times as long as broad, midrib usually sunken and slightly puberulous, upper lamina with minute raised dots, petiole and rhachis unwinged, capsule often globose and minutely tuberculate, ribbed or not

21a. subsp. pubescens

1b. Leaves narrowly elliptic or lanceolate, usually more than 3 times as long as broad, midrib raised on the upper surface, glabrous, upper lamina without raised dots, petiole and rhachis narrowly winged, capsule depressed globose, irregularly ribbed 21b. subsp. pubiflora

\section{1a. Guarea pubescens subsp. pubescens. Figs 16, 48F.}

Distribution and ecology. Venezuela and the Guianas, northern and central Amazonian Brazil, Amazonian Colombia, Ecuador, Peru and Bolivia, occurring in nonflooded lowland rain forest.

Representative additional collections. Colombia. Amazonas: R. Caqueta, El Engano (SW0071), Duivenvoorden et al. 1574 (K). Caqueta: Araracuara (SW0072), Gentry \& Sanchez 65007 (K).

Venezuela. Amazonas: Atabapo, Rio Padamo (NW0365), Marin 839 (K). Apure: Pedro Camejo, Fundo Las Delicias (NW0768), Gomez \& Bevilacqua 320 (K). Bolívar: Municipio Sucre, Helipuerto 23 (NW0664), Delgado 1014 (K). Zulia: $55 \mathrm{~km} \mathrm{SW}$ of Machiques, Aricuaisa (NW0972), Liesner \& Gonzalez 13143 (K).

GuYana. Upper Takutu-Upper Essequibo, Kwitaro River (NW0358), D. Clarke et al. 6515 (K); Potaro-Siparuni region, Iwokrama Reserve (NW0458), Mutchnick 946 (K).

Surinam. Sipaliwini, along Ulemari River, $13 \mathrm{~km}$ upstream from confluence with Litani River, (NW0354), Hammel et al. 21298 (K).

French Guiana. Haut Litany-Bassin de Litany (NW0254), de Granville et al. 11962 (K).

ECuAdor. Morona-Santiago: Taisha (SW0277), Little et al. 747 (COL, QCNE). Orellana:

Rio Tiputini, Yasuní Scientific Research Station (SW0076), Bass 357 (F, NY). Sucumbíos: Cantón Lago Agrio, Dureno (SW0076), Cerón 378 (NY).

Peru. Amazonas: Condorcanqui, El Cenepa, Mamayaque (SW0478), Vásquez et al. 22284

(F). Loreto: Iquitos, Puerto Almendras (SW0373), Pennington et al. 12467 (K, MOL). Madre de Dios: Tambopata Explorer's Inn Tourist Camp (SW1269), Gentry et al. 51439 (K). Ucayali: Von Humboldt Reserve (SW0875), Pennington et al. 16514 (K, MOL).

Brazil. Acre: Feijo, basin of R. Muru (SW0871), Delprete et al. 8517 (K). Amapá: Reserva INCRA Rio Falsino (NW0151), Campbell et al. 14472 (K). Pará: Ilha de Marajó, Rio Jipuru (SW0050), Tavares 233 (K).

Bolivia. Pando: Nicolas Suarez, Campamento San Sebastian (SW1169), Paniagua et al. 2018 (F, K).

21b. Guarea pubescens subsp. pubiflora (A.Juss.) T.D.Penn. in T.D.Penn. et al., Fl. Neotrop. 28: 298 (1981). - Guarea pubiflora A.Juss., Bull. Sci. Nat. Géol. 23: 240 (1830); Mém. Mus. Hist. Nat. 19: 241, 287 (1831). - Type: Brazil, Amazonas (Rio Negro), Barcellos, fl., Collector unknown s.n. (holo P). Figs 16, 49A.

For synonymy see T.D.Penn. in T.D.Penn. et al., Fl. Neotrop. 28 : 298 (1981). 


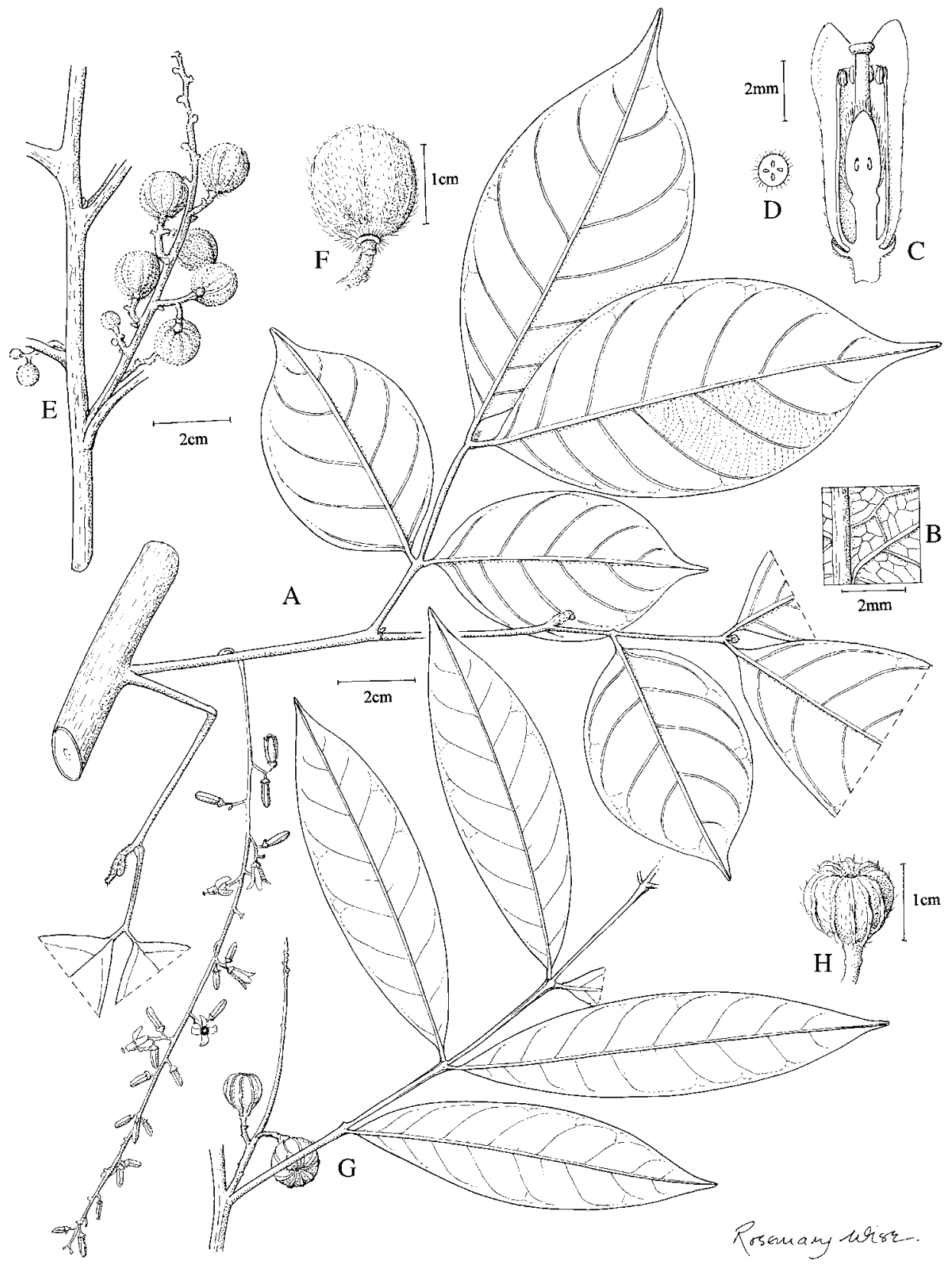

FIG. 16. Guarea pubescens (Rich.) A.Juss. A-F, subsp. pubescens: A, habit; B, enlargement of leaf undersurface; C, half-flower; D, cross-section of ovary; E, infructescence; F, fruit. G, H, subsp. pubiflora (A.Juss.) T.D.Penn.: G, habit; H, fruit. (A-D, Mori \& Pipoly 15626; E, F, Jenman 316; G, H, Acevedo-Rodriguez et al. 7967). 
Distribution and ecology. Southern Venezuela, French Guiana and central and southern Amazonian Brazil, confined to riverbanks and periodically and permanently flooded forest. Common along the middle reaches of the Amazon river and along its major tributaries, but apparently not reaching Peru or Ecuador. In Venezuela it is common along the middle and upper Orinoco basin. We have seen no records yet from Colombia, but it is almost certainly to be found along the rivers which share a frontier with Venezuela.

Representative additional collections. Venezuela. Apuré: Distrito Romulo Gallegos, between Laguna del Término and Rio Capanaparo (NW0669), Davidse \& Gonzalez 16158 (K).

French Guiana. Le Tampoc, above Saut Koumaiou Soula (NW0353), Cremers 4505 (K); Bas-Camopi (NW0352), Oldeman 1330 (K).

Brazil. Amazonas: R. Parauari, tributary of R. Maues-Acu, at Agua Mineral (SW0457), Hill et al. 13073 (K).

Bolivia. La Paz: Prov. Iturralde, Luisita (SW1367), Beck \& Haase 10162 (K). Pando: Prov. Federico Roman, Rio Abuna (SW0965), Vargas et al. 1049 (K). Santa Cruz: Prov. Velasco, El Refúgio Ecological Reserve (SW1461), Guillen \& Chore 3379 (K).

22. Guarea zarceroensis Coronado, Novon 16(4): 466 (2006). - Type: Costa Rica, Alajuela, San Carlos, Sucre [NW1084], fl., A. Smith 1686 (holo NY; iso F, MO). Figs 17, 59B.

Young shoots 3-4 mm diam., pale-pubescent at first, soon glabrous, pale buff, smooth, with or without large pustular lenticels. Leaves pinnate with a terminal bud showing intermittent growth, petiole 5-9 cm long, semiterete to slightly channelled at the base, glabrous, rhachis $8-18 \mathrm{~cm}$ long, semiterete, glabrous; petiolule $1.5-1.7 \mathrm{~cm}$ long. Leaflets 3-6 pairs, 9.5-18.5 × 4-8.6 cm, broadly elliptic, apex obtusely cuspidate, base narrowly attenuate and decurrent on the petiolule, chartaceous, glabrous, obscurely glandular-striate; venation eucamptodromous, midrib flat on the upper surface (not raised or sunken), secondaries 5-7 pairs, ascending, slightly arcuate and convergent, intersecondaries few, moderate to long, or absent, tertiaries oblique, obscure. Inflorescence axillary and on twigs below the leaves, 4-15 cm long, a slender lax-flowered panicle, the lower lateral branches to $1-1.5 \mathrm{~cm}$ long, with scattered minute appressed hairs or glabrous; pedicel 3-4 mm long, with sparse appressed hairs. Calyx closed in bud, in male flower $2.5-3.5 \mathrm{~mm}$ long, cup-shaped and irregularly 3-4-lobed to c.1/2 its length, with scattered minute appressed hairs outside, glabrous inside. Petals 4, 6-8 $\times$ 2-3 mm, strap-shaped, apex acute, appressed puberulous outside, glabrous inside. Staminal tube 5-6 $\times 2-2.5 \mathrm{~mm}$, cylindrical, margin undulate, glabrous; anthers 8-9, c.1.5 mm long, glabrous. Nectary a short stout stipe below the ovary. Ovary ovoid, c.2 mm long, 4-6-locular, locules with 1-2 superposed ovules, appressed pubescent, style c. $2 \mathrm{~mm}$ long, style-head discoid. Female flowers not seen. Capsule c. $2.5 \times 3 \mathrm{~cm}$, depressed-globose, apex truncate, base obtuse, 4-6-valved, valves strongly and irregularly ribbed, the ribs anastomosing and strongly tuberculate in the upper half, minutely puberulous, pericarp $3-5 \mathrm{~mm}$ thick, valves with $1-2$ superposed seeds. Seed (immature), 6-8 $\mathrm{mm}$ long. 


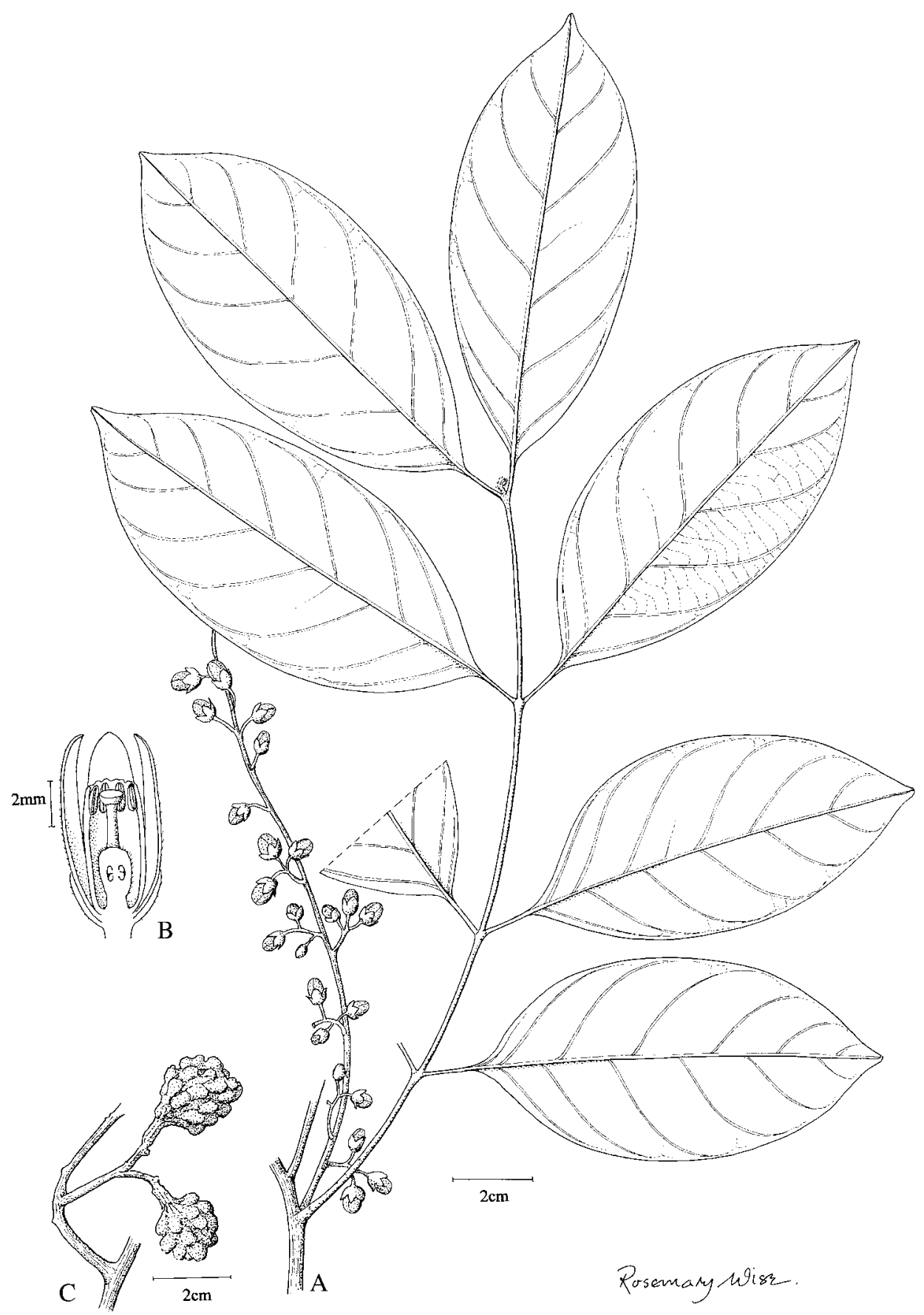

FIG. 17. Guarea zarceroensis Coronado. A, habit; B, half-flower; C, fruit. (A, B, Smith, A. 1686; C, Smith, A. 2899). 
Field characters. Tree to $30 \mathrm{~m}$ high and $1 \mathrm{~m}$ diam., but flowering when a small treelet 2-3 m high, bark brown and scaling. Flowers with white or cream-coloured petals and yellow anthers. Capsule hard and strongly tuberculate. Flowering recorded in March, July and October, with a single fruiting collection in July.

Distribution and ecology. Known only from Alajuela and Limón, Costa Rica, in wet lowland and montane rain forest between $500 \mathrm{~m}$ and $1550 \mathrm{~m}$ altitude.

Collections examined. Costa Rica. Alajuela: Upala, PN Rincon de la Vieja, Cuenca del Pizote (NW1085), Gonzalez \& Porras 3911 (INB); Upala, Dos Rios, 5 km S of Brasilia (NW1085), Herrera 1053 (K, MO); San Luis de Zarcero (NW1084), A. Smith 861 (F, MO); Alfaro Ruiz, Zarcero (NW1084), A. Smith 2899 (F). Limón: Matina, RI Barbila-Dantas, Cuenca de Matina (NW1083), Rodríguez et al. 6121 (INB).

In the absence of fruits, specimens belonging to this species were wrongly assigned to Guarea glabra in the Flora Neotropica treatment (Pennington et al., 1981). It is distinctive in its combination of few secondary veins (5-7 pairs), leaflets with long petiolules, flowers on long pedicels and 4-merous flowers with pubescent petals and ovary. Its strongly ribbed and tuberculate fruit is similar to that of the South American Guarea macrophylla but the few secondary veins, long petiolule, long pedicel and laxflowered inflorescence are distinctive.

The ITS phylogeny indicates a relationship that is not supported by the morphology, with Guarea zarceroensis placed in a small group containing G. tafae-malekui and G. macrocalyx, and all apparently having arisen recently from South American stock.

23. Guarea tafae-malekui Al.Rodr., Lankesteriana 6: 115 (2006). - Type: Costa Rica, Alajuela, San Carlos, Parque Nacional Arenal, basin of San Carlos, Cerro Chato, fl., fr., A. Rodríguez et al. 6238 (holo INB; iso CR, MO). Figs 18, 59C.

Young shoots $1.2-1.5 \mathrm{~cm}$ diam., hollow, minutely puberulous at first, soon glabrous, pale brown, smooth, without lenticels. Leaves pinnate with a terminal bud with intermittent growth, petiole $10-28 \mathrm{~cm}$ long, channelled at the base to semiterete at the apex, minutely puberulous to glabrous, rhachis up to $55 \mathrm{~cm}$ long, semiterete, subglabrous; petiolule 5-7 mm long, glabrous. Leaflets opposite, up to 8 pairs, 17$32 \times 6-10 \mathrm{~cm}$, broadly oblong or oblanceolate, apex narrowly attenuate, base acute or narrowly cuneate, chartaceous, glabrous, not glandular-punctate or -striate; venation eucamptodromous, midrib flat or slightly sunken on the upper surface, secondaries 13-15 pairs, ascending, slightly arcuate, slightly convergent, intersecondaries absent, tertiaries numerous, fine, oblique. Inflorescence axillary or below the leaves, 8-15 cm long, a slender, few-flowered panicle, lateral branches to $3 \mathrm{~cm}$ long; pedicel up to $5 \mathrm{~mm}$ long, with 3-4 bracteoles 3-10 $\mathrm{mm}$ long. Male flowers only seen. Flowers subtended by bracts 4-6 mm long, narrowly lanceolate, keeled. Calyx 7-10 mm long, cup-shaped with 4 shallow to deep lobes, lobes ovate, slightly keeled, abruptly contracted at the apex into an acumen 1-2 mm long, densely puberulous. Corolla acute in bud, petals $4,1.5-1.7 \mathrm{~cm}$ long, $8-10 \mathrm{~mm}$ broad, apex acute, 


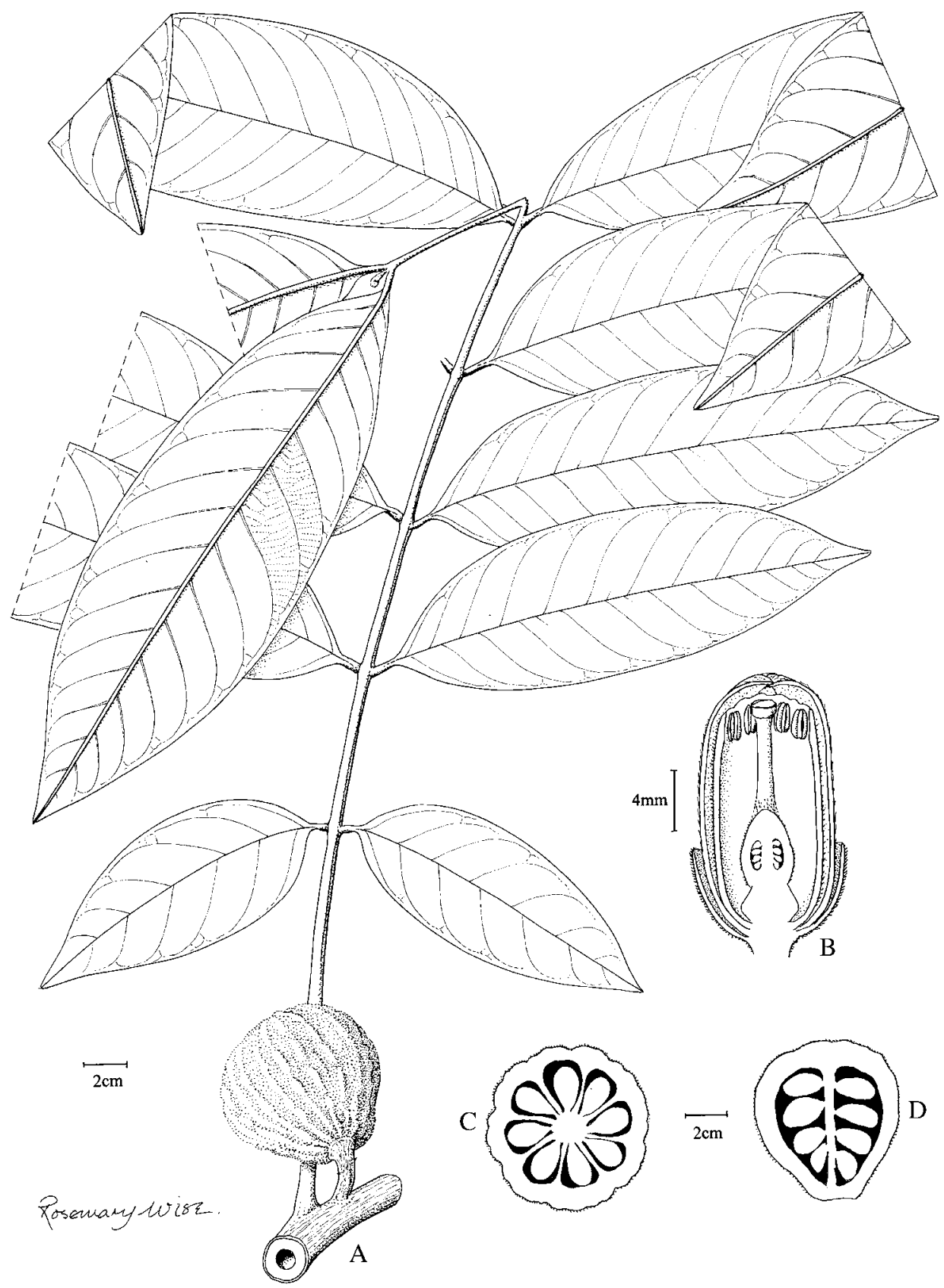

FIG. 18. Guarea tafae-malekui Al.Rodr. A, habit with fruit; B, half-flower; C, cross-section of fruit; D, longitudinal section of fruit. (A, C, D, Funk et al. 10772; B, Rodriguez et al. 6238). 
sericeous outside, papillose inside. Staminal tube 1.4-1.6 cm long, 7-9 mm broad, margin denticulate, papillose outside; anthers $8-9$, c. $3 \mathrm{~mm}$ long, glabrous. Nectary 2-2.5 mm long, a stout stipe expanded below the ovary, glabrous. Ovary 6-8-locular, locules with (3-)4 superposed ovules, minutely sericeous. Capsule c. $6 \times 7 \mathrm{~cm}$, globose to broadly pyriform, apex obtuse to truncate, base obtuse, finely puberulous, 6-8-valved, pericarp c. $1 \mathrm{~cm}$ thick, slightly tuberculate and ribbed when dry, valves $1-4$-seeded. Seeds $0.5-1.6 \mathrm{~cm}$ long, surrounded by a thin sarcotesta.

Field characters. Monopodial treelet to $5 \mathrm{~m}$ high, flowers creamy white, mature fruit reddish brown. Flowering and fruiting recorded in February.

Distribution and ecology. Costa Rica, in wet forest on the Caribbean slopes of the Cordillera de Tilarán, between $400 \mathrm{~m}$ and $1000 \mathrm{~m}$ altitude.

Collections examined. Costa Rica. Alajuela: Arenal Volcano, Macadamia field to river (NW1084), Funk et al. 10772 (MO, US); San Carlos, Volcan Arenal, Fortuna, track to Tabacón (NW1084), Jiménez et al. 1458 (INB), Rodríguez 8526 (INB); San Carlos, La Fortuna, R.B. Arenal (NW1084), Rodríguez \& Lepiz 9949 (INB), 9950 (INB), 9951 (INB), 9952 (INB), 9953 (INB). Guanacaste: 6 km N of Rio Chiquito, above Lake Arenal (NW1084), Haber et al. 4825 (CR).

This is an interesting and morphologically very distinct species. The multilocular ovary with 3-4 ovules in each locule is unique to the subfamily Melioideae. Hitherto, multiovulate ovary locules have been known only in species of subfamily Cedreloideae. Other unusual characters are the calyx lobes with a sharp apical acumen and the acute corolla, unlike any other Guarea except G. macrocalyx. The species is easily recognised by the hollow twigs, large leaflets, large flowers, acuminate calyx lobes, large (1.5-1.7 cm long) acute corolla (when in bud), 6-8-locular ovary with 3-4 ovules in each locule, and large multilocular capsule with several seeds in each valve. The ITS phylogeny places this species next to Guarea macrocalyx.

24. Guarea macrocalyx Al.Rodr., Lankesteriana 6: 110 (2006). - Type: Costa Rica, San José, Perez Zelendon, Tinamaste, Finca de los Suizos, fl., A. Estrada 832 (holo CR; iso INB). Figs 19, 59D.

Young shoots 6-9 mm diam., not hollow, minutely puberulous at first, soon becoming glabrous, smooth, pale buff, with scattered lenticels. Leaves pinnate with a terminal bud with intermittent growth, petiole $10-20 \mathrm{~cm}$ long, semiterete, puberulous to glabrous, rhachis up to $50 \mathrm{~cm}$ long, semiterete, glabrous; petiolule $1-1.6 \mathrm{~cm}$ long. Leaflets opposite, up to 7 pairs, $17.5-33 \times 8.4-13.5 \mathrm{~cm}$, elliptic to broadly lanceolate, apex acuminate to obtusely cuspidate, base acute, obtuse or rounded, chartaceous, glabrous, not glandular-punctate or -striate; venation eucamptodromous, midrib flat or slightly raised (rounded) on the upper surface, secondaries 12-16 pairs, ascending, straight or slightly arcuate, mostly parallel, intersecondaries absent, tertiaries numerous, fine, oblique. Inflorescence axillary or ramiflorous, 5$25 \mathrm{~cm}$ long, a slender raceme or panicle, few- to many-flowered, lateral branches to 


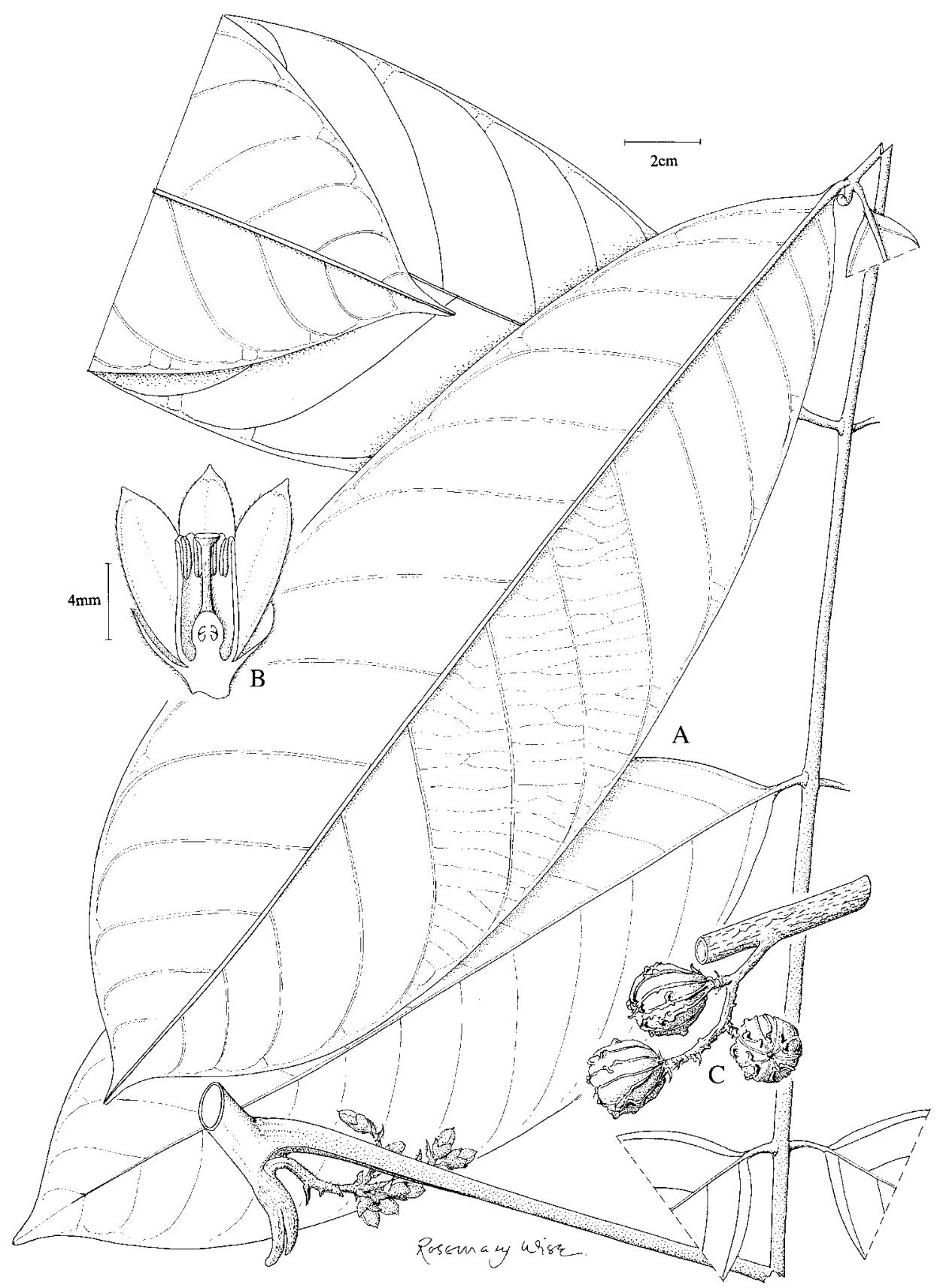

FIG. 19. Guarea macrocalyx Al.Rodr. A, habit; B, half-flower; C, fruit. (A, B, Herrera et al. 7392; C, Kernan 1214). 
$5 \mathrm{~cm}$ long, finely puberulous; pedicel 2-4 mm long, bracteoles 4-5 $\mathrm{mm}$ long, subulate. Flower buds oblong, narrowly acute at the apex. Flowers subtended by sharply acute lanceolate bracts, c.5 mm long. Calyx closed in bud, 5-14 mm long, cyathiform, 23-lobed to halfway or more, lobes keeled, contracted at the apex into a slender subulate point, sparsely puberulous, calyx usually persists in fruit. Corolla apex acute in bud, petals 4-6, 8-14 cm long, 3.5-5 $\mathrm{mm}$ broad, apex acute, sericeous outside, papillose inside. Staminal tube 6-9 $\mathrm{mm}$ long, c. $3 \mathrm{~mm}$ broad, margin crenulate, glabrous; anthers 8-9, 1.75-2.5 mm long, glabrous. Nectary a broad stipe c.1 mm long. Ovary 1.5$1.75 \mathrm{~mm}$ long, 4-5-locular, locules with 2 superposed ovules, densely pubescent, style 5-6 mm long, style-head discoid. Capsule (immature) c. $2 \times 2 \mathrm{~cm}, \pm$ globose or broadly pyriform, apex truncate, base obtuse, 4-5-valved, valves with 1-2 superposed seeds, each valve with 3 shallow longitudinal ribs, the ribs tuberculate in the upper half, finely puberulous intermixed with longer hairs, pericarp c.1 mm thick. Seeds not seen.

Field characters. Unbranched treelet to $3.5 \mathrm{~m}$ high with whitish flowers, flowering in December and January, fruit maturing in August.

Distribution and ecology. Costa Rica, in rain forest on both the Pacific and Caribbean slopes (Limón and Puntarenas), and in the Osa Peninsula, up to $900 \mathrm{~m}$ altitude.

Collections examined. Costa Rica. Limón: Talamanca, Cuenca de Sixaola, San Miguel, (NW0982), Gonzalez 1711 (INB). Puntarenas: Osa, Reserva Forestal Golfo Dulce, Aguabuena (NW0883), Aguilar 790 (INB); Cantón de Golfito Jimenez, Dos Brazos del Rio Tigre, Cerro Rincón (NW0883), Herrera 4162 (INB, K); Cantón de Osa Sierpe, San Juan, between Guerra and San Juan, track to Cerros Chocuaco (NW0883), Herrera 4876 (INB, MO); Corcovado National Park, Sirena, Los Patos (NW0883), Kernan 1214 (INB, K).

The calyx of this species is unusual but similar to that of Guarea tafae-malekui: deeply 2-3-lobed, the lobes keeled and contracted at the apex into a subulate point, and it is usually persistent in fruit. The acute corolla bud is also unusual and the small ribbed and tuberculate capsule is distinctive.

Only the type specimen has large flowers and the fruit seen by us are only half the size of that in the protologue.

25. Guarea velutina A.Juss., Bull. Sci. Nat. Géol. 23: 240 (1830); A.Juss., Mém. Mus. Hist. Nat. 19: 241, 288 (1831); T.D.Penn. in T.D.Penn. et al., Fl. Neotrop. 28: 299, fig. 60 (1981). - Type: Brazil, fl., Collector unknown, annotated 'Herbar Lusitanicum, Bresil' (holo P). Fig. 49B.

Abbreviated description. Young shoots velutinous to tomentose, leaves with indeterminate apical growth, leaflets 2-6 pairs, 10-21 × 4.6-7.3 cm, elliptic, oblong or lanceolate, base usually obtuse or truncate, coriaceous, lower surface densely pubescent with crisped hairs to subglabrous, and with minute red papillae, tertiary veins obscure, inflorescence 4-33 cm long, a pyramidal thyrse, petals $3-5$, valvate, 7-10 $\mathrm{mm}$ long, $1.5-2.5 \mathrm{~mm}$ broad, staminal tube $6-8 \mathrm{~mm}$ long, $2-2.5 \mathrm{~mm}$ broad, 
anthers 8-9, ovary ribbed, 4-5-locular, locules 1-ovulate, densely pubescent, capsule c.3.5 cm long, $3.5-4.5 \mathrm{~cm}$ broad, 4-valved, \pm globose, each valve with 3-4 thin convoluted and anastomosing longitudinal wings up to $1 \mathrm{~cm}$ deep, finely puberulous, pericarp (excluding wings), 3-5 mm thick, valves 1-seeded.

Distribution and ecology. Amazonian Colombia, Guyana and Amazonian Brazil, a plant of lowland rain forest on non-flooded sites, sometimes recorded from poorly drained land.

Additional collections examined. Colombia. Amazonas: R. Caqueta, by Isla Sumaeta (SW0072), van Dulmen 372 (K).

GuYana. Region Upper Takutu-Upper Essequibo, Kuyuwini R., Honey Creek (NW0159), D. Clarke 4461 (K), 4594 (K); South Kassikaityn R., to Wassarai Mts. (NW0159), D. Clarke et al. $7932(\mathrm{~K}), 8056(\mathrm{~K})$.

Brazil. Acre: Upper Río Moa near Fazenda Arizona (SW0773), Campbell et al. 6523 (K); Municipio Novo Airao, Rio Camanau, Aldeia Maré (SW0161), Milliken et al. (Miller 345) (K). Amazonas: western massif of Serra Araca (NW0063), Prance et al. 29462 (K); Manaus, Distrito Agropecuario, BR 174, km 72 (SW0260), da Silva et al., INPA/WWF 2108.412.2 (K); Presidente Figueiredo, Represa de Balbina (SW0159), Thomas et al. 5306 (K). Pará: Municipio Oriximina, BR 163, $14 \mathrm{~km} \mathrm{~N}$ of Cachoeira Porteira (SW0057), Cid Ferreira et al. 7945 (F, K). Rondonia: Municipio de Porto Velho, Reservatorio de Usina Hidreletrica de Samuel (SW0863), Cid Ferreira et al. 7546 (K).

This species is morphologically close to Guarea juglandiformis, but no ITS sequence data were available to confirm whether they are related.

26. Guarea costata A.Juss., Bull. Sci. Nat. Géol. 23: 240 (1830); A.Juss., Mém. Mus. Hist. Nat. 19: 241, 291 (1831); T.D.Penn. in T.D.Penn. et al., Fl. Neotrop. 28: 303, fig. 61 (1981). - Type: Cayenne (French Guiana), young fr., Perrottet s.n. (holo P). Figs 20, 49C.

Abbreviated description. Young shoots and inflorescences finely appressed puberulous, leaves with a terminal bud showing intermittent growth, leaflets up to 6 pairs, 13-20 × 5-6.6 cm, usually oblanceolate, or broadly oblong, subcoriaceous, glabrous, secondary veins $8-11$ pairs, inflorescence axillary, 6-12 cm long, a slender thyrse, petals 4 , valvate, 5.5-6.5 $\mathrm{mm}$ long, staminal tube 5-5.5 $\mathrm{mm}$ long, $1.5-2 \mathrm{~mm}$ broad, anthers 8, ovary 4-locular, locules 1-ovulate, capsule c. $2 \mathrm{~cm}$ long (including the stipe), c. $1.8 \mathrm{~cm}$ broad, globose or depressed globose, contracted at the base into a stipe $0.5-0.8 \mathrm{~cm}$ long, 4-valved, each valve with 3 longitudinal ribs or narrow wings to $2.5 \mathrm{~mm}$ deep, pericarp c. $2 \mathrm{~mm}$ thick, minutely appressed puberulous, with minute red papillae, valves 1 -seeded.

Distribution and ecology. Surinam and French Guiana, in lowland rain forest on non-flooded lateritic sites.

Additional collections examined. Surinam. Lely Mountains, SW plateau (NW0454), Lindeman et al. $97(\mathrm{U}), 130(\mathrm{~K}, \mathrm{NY}), 236(\mathrm{~K})$. 


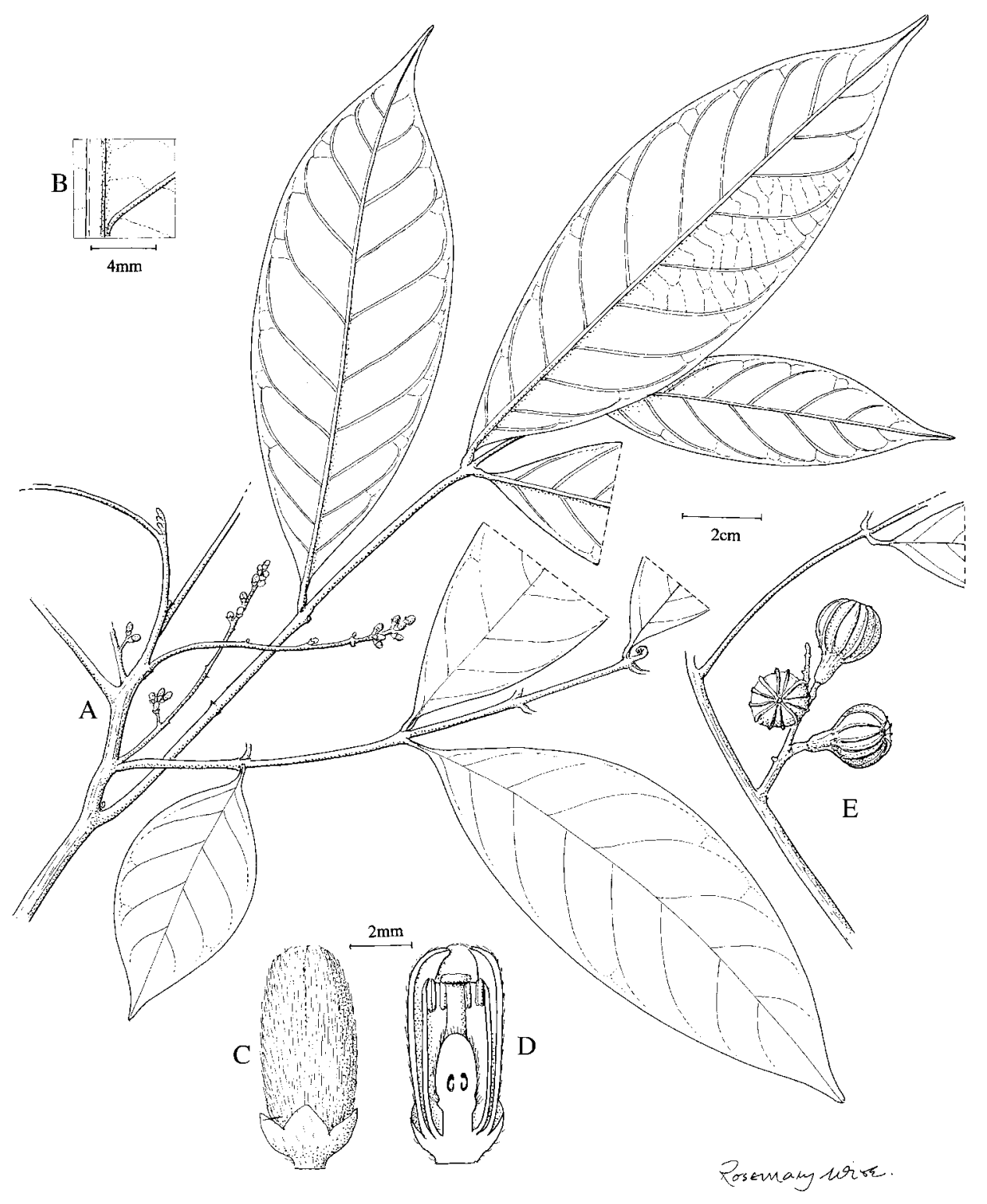

FIG. 20. Guarea costata A.Juss. A, habit; B, enlargement of leaf undersurface; C, flower bud; D, half-flower; E, infructescence. (A, C, D, Lindeman et al. 130; B, Amshoff 2500; E, de Granville 8072).

French Guiana. Montagne Bellevue de l'Inini (NW0353), de Granville et al. 8072 (K, U); Mont Atachi Bacca (NW0353), de Granville et al. 10707 (K); Bassin de Sinnamary, Crique Plomb (NW0553), Loubry 1729 (K).

Closely related to Guarea velutina which also shares the winged capsule. 
27. Guarea guentheri Harms, Notizbl. Bot. Gart. Berlin-Dahlem 10: 243 (1928); T.D.Penn. in T.D.Penn. et al., Fl. Neotrop. 28: 352 (1981). - Type: Peru, Amazonas, mouth of R. Santiago, fl., Tessmann 4156 (holo B, destroyed; lecto NY, designated here; isolecto F (fragment)). Figs 21, 53C.

Abbreviated description. Young shoots and inflorescences appressed puberulous to shortly pubescent, leaves with a terminal bud showing intermittent growth, leaflets up to 6 pairs, $18-31 \times 7-11 \mathrm{~cm}$, elliptic, oblong or oblanceolate, chartaceous, \pm glabrous above, sparsely pubescent on midrib and veins below, and lamina with numerous minute red papillae, secondary veins 14-18 pairs, inflorescence axillary, ramiflorous or cauliflorous, 5-20 cm long, a slender panicle, sometimes with several branches from the base, petals 4 , valvate, $12-15 \mathrm{~mm}$ long, densely appressed puberulous outside, staminal tube 9.5-12 mm long, 2.5-3 mm broad, anthers (7-)8, ovary 4-locular, locules with 2 superposed ovules, capsule $4-6.5 \times 2.2-3 \mathrm{~cm}$, shortly botuliform to \pm pyriform, sometimes slightly constricted between the seeds, tapering at the base into a stout stipe c. $1 \mathrm{~cm}$ long, obscurely ribbed, ribs plicate or torulose, minutely puberulous, 4-valved, valves with 2 superposed seeds, pericarp 2-5 mm thick.

Distribution and ecology. Extreme western Amazonian Brazil, Amazonian Ecuador and Peru, ascending to $900 \mathrm{~m}$ altitude in the foothills of the Andes. It is a small tree of rain forest on non-flooded sites.

Additional collections examined. EcuAdor. Morona-Santiago: Cordillera de Cutucú, Centro Shuar (SW0277), Toasa \& Tirado 8731 (MO). Napo: 8 km below Misahuallí, Jatun Sacha Reserve (SW0177), Palacios \& Neill 957 (K, MO). Orellana: Estación Experimental INIAP Napo, Payamino (SW0077), Palacios et al. 1180 (MO); Estación Experimental INIAP, San Carlos (SW0076), Palacios \& Neill 1272 (K). Pastaza: Villano-Triunfo km 17 (SW0177), Palacios 12097 (K). Sucumbios: Lumbaqui (NW0077), Pennington et al. 12229 (K).

Peru. Amazonas: Bagua Province, Yamayakat (SW0478), Jaramillo et al. 1080 (K), 1186 (MO); Imaza, Kampaensa (SW0478), Rodríguez 618 (K); Rio Santiago, Caterpiza (SW0377), Tunqui 333 (MO). Loreto: Yanamono, Explorama Tourist Camp (SW0372), Gentry et al. 60908 (K, MO); Napo District, Rio Santa Maria (SW0174), King 506 (K); Maynas, Iquitos, R. Itaya, Buena Suerte (SW0373), Vásquez \& Jaramillo 8433 (MO). Pasco: Oxapampa, Pichis valley, near Paujil (SW1074), Foster et al. 8932 (F, K).

Brazil. Acre: upper Rio Moa, near Fazenda Arizona (SW0773), Campbell et al. 6443 (K).

The dried leaves and fruit smell strongly of curry powder. It is the only species of Guarea recognisable by smell alone.

28. Guarea macrophylla Vahl, Eclog. Amer. 3: 8 (1807); T.D.Penn. in T.D.Penn. et al., Fl. Neotrop. 28: 281, fig. 57 (1981). - Type: St. Croix, Montserrat, fl., Ryan s.n. (holo C). Figs 22, 23.

For synonymy see T.D.Penn. in T.D.Penn. et al., Fl. Neotrop. 28: 282 (1981).

Abbreviated description. Indumentum inconspicuous, puberulous or pubescent, leaves with indeterminate apical growth or not, leaflets $2-7(-9)$ pairs, 6-25(-33) $\times$ $2.6-8(-10.5) \mathrm{cm}$, elliptic, oblong or oblanceolate, rarely obovate, secondary veins 


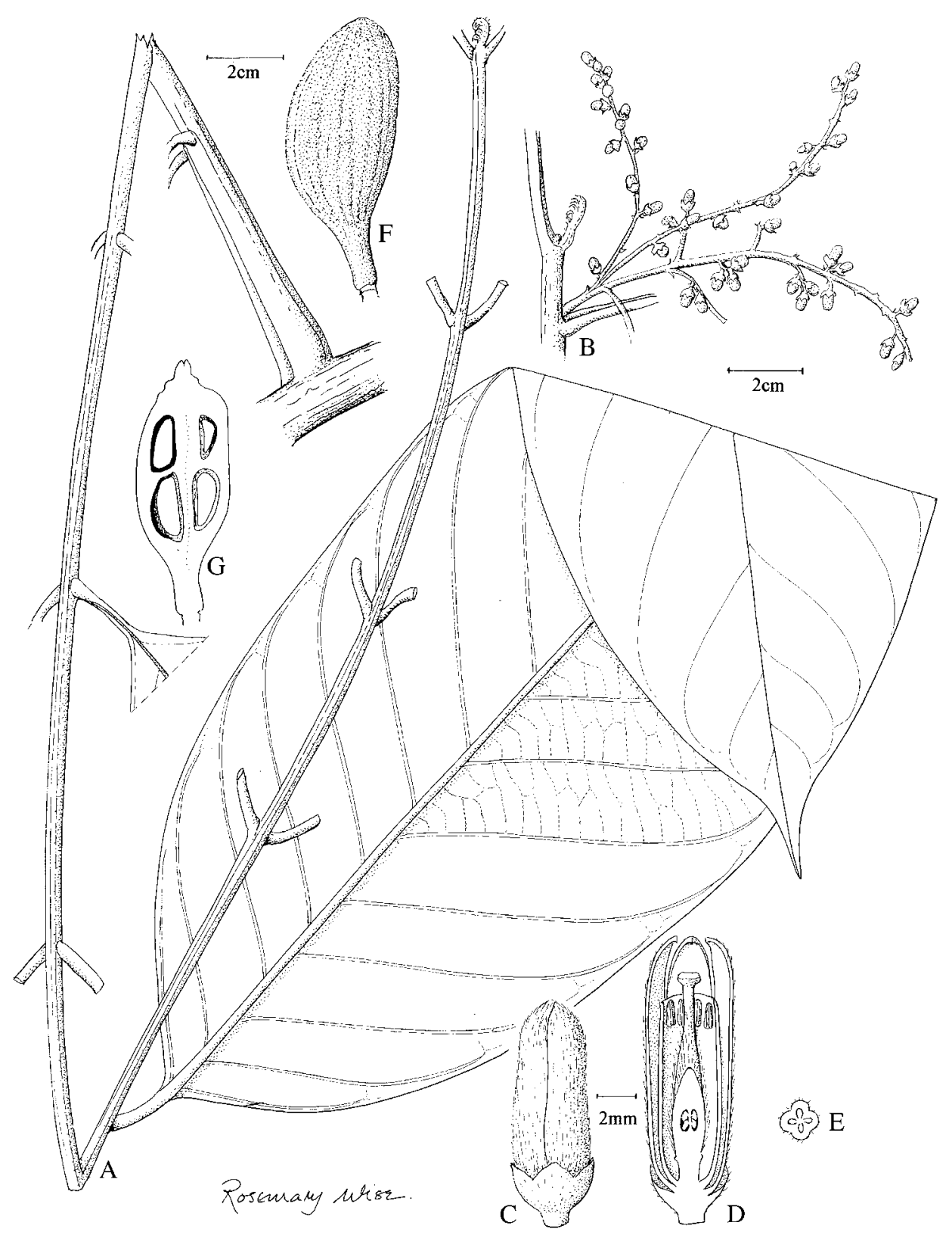

FIG. 21. Guarea guentheri Harms. A, habit; B, inflorescence; C, flower bud; D, half-flower; E, cross-section of ovary; F, fruit; G, longitudinal section of fruit. (A, F, G, Palacios \& Neill 957; B, Palacios et al. 1180; C-E, Krukoff 8240).

6-14(-16) pairs, inflorescence axillary or below the leaves, (2-)8-35(-55) cm long, a slender thyrse, petals 4-5, valvate, (5-)6-9(-11) $\mathrm{mm}$ long, staminal tube 4.5-7(-8.5) mm long, 1.5-3(-4) mm broad, anthers 8(-10), ovary (3-)4(-5)-locular, 


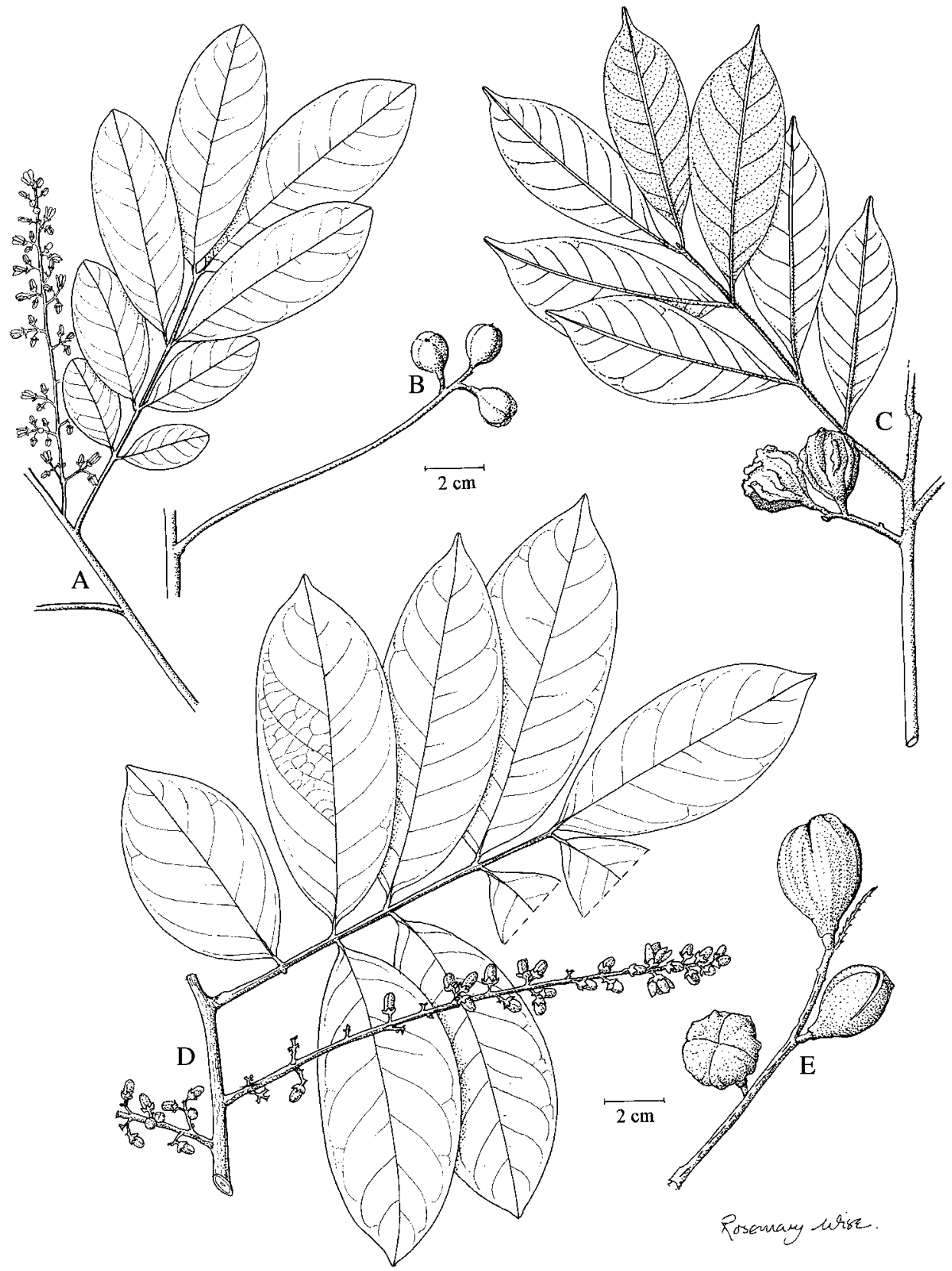

Fig. 22. Guarea macrophylla Vahl. A, B, subsp. spiciflora (A.Juss.) T.D.Penn.: A, habit; B, infructescence. C, subsp. tuberculata (Vell.) T.D.Penn., habit. D, E, subsp. macrophylla: D, habit; E, infructescence. (A, Hassler 42391; B, Zardini \& Hellman 48976; C, Martinelli 1074; D, Rutkis 472; E, Beard 229). 


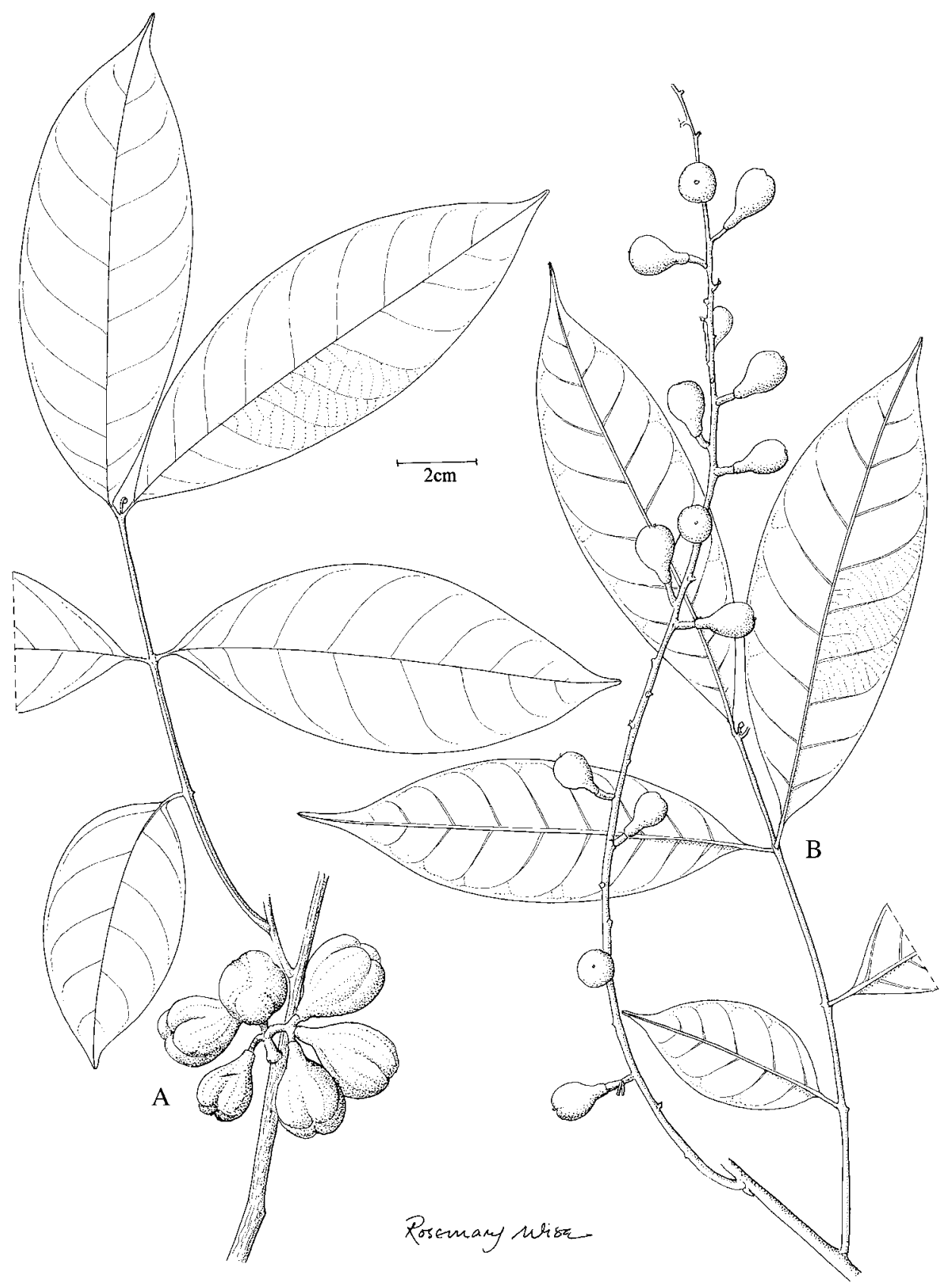

FIG. 23. Guarea macrophylla Vahl. A, subsp. pachycarpa (C.DC.) T.D.Penn., habit. B, subsp. pendulispica (C.DC.) T.D.Penn., habit. (A, Oldeman 1221; B, Jansen-Jacobs et al. 2487). 
locules with 1-2 superposed ovules, puberulous or pubescent, capsule $0.75-3.5 \mathrm{~cm}$ long, depressed globose, globose or fig-shaped, usually tapering gradually to base, 4(-5)-valved, valves tuberculate, torulose, 2-3-ribbed or smooth, often wrinkling on drying, minutely puberulous to pubescent, pericarp 1-2 mm thick, valves with 1-2 superposed seeds.

\section{8a. Guarea macrophylla subsp. macrophylla. Figs 22, 66B.}

Leaflets variable in shape, \pm glabrous, without red papillae, secondary veins \pm parallel, leaves with a dormant, non-active terminal bud, inflorescence a slender thyrse to $55 \mathrm{~cm}$ long, petals 9-11 mm long, anthers $1.25-1.5 \mathrm{~mm}$ long, capsule $2.5-3.5 \mathrm{~cm}$ long, subglobose to fig-shaped, shallowly and irregularly costulate or torulose, papillosepuberulous, valves with 1(-2) superposed seeds.

Distribution and ecology. Lesser Antilles and northern Venezuela, in lowland and lower montane rain forest up to $700 \mathrm{~m}$ altitude.

Additional collections examined. WINDWARD IsLANDS. Dominica: Syndicate Estate, GR 692157 (NW1561), Pendry 82204 (K).

Venezuela. Yaracuy: San Felipe, Aroa to Cocorote (NW1068), Rutkis 476 (K).

28b. Guarea macrophylla subsp. tuberculata (Vell.) T.D.Penn. in T.D.Penn. et al., Fl. Neotrop. 28: 285, fig. 58 (1981). Figs 22, 63B.

Guarea tuberculata Vell., Fl. Flum. 150 (1829); Vell., Fl. Flum. 4: t. 10 (1831). - Type: [icon] Vellozo, Fl. Flum. 4: t. 10 (1831).

For synonymy see T.D.Penn. in T.D.Penn. et al., Fl. Neotrop. 28: 285-287 (1981).

Leaflets variable in shape, often pubescent on lower surface, sometimes with granular red papillae, secondary veins usually convergent, leaves with an active terminal bud showing intermittent growth, inflorescence usually a slender laxlyflowered thyrse, occasionally with a few short branches at base, to $25(-35) \mathrm{cm}$ long, petals (5-)6-9 mm long, anthers (0.75-)1-1.5 mm long, fruit (1-) $1.5-3 \mathrm{~cm}$ long, depressed-globose to fig-shaped, usually prominently tuberculate and/or ribbed, densely to sparsely pubescent, valves with 1-2 superposed seeds.

Distribution and ecology. Eastern, central and southeastern Brazil, Paraguay, Bolivia and doubtfully in Amazonian Peru (see note below). In southeastern Brazil it occurs in lowland rain forest. Further to the north and west it appears to be confined to gallery forest in drier cerrado vegetation. Ascending to $1200 \mathrm{~m}$ altitude in 'brejo' forest in Bahia.

Representative additional collections. BRAzIL. Bahía: Municipio Lençois, Chapadinha (SW1241), Gasson et al. 5880 (K). Distrito Federal: Municipio Brasilia, Fazenda Sucupira (SW1547), Sampaio et al. 184 (K). Espirito Santo: Conceição da Barra, Parque Estadual de Itaunas (SW1940), Salino \& Moraes 4489 (K). Paraná: Municipio de Jaguariaiva, Parque Estadual do Cerrado (SW2449), von Linsingen \& Sonehara 588 (K). Pernambuco: São Vicente 
Ferrer, Mata do Estado (SW0735), Ferraz \& Melo 721 (K). Rio de Janeiro: Municipio Porati, Apa-cairucu (SW2344), Konno 109 (K). São Paulo: Socorro (SW2246), Groppo 874 (K).

Bolivia. Santa Cruz: Prov. Velasco, R. Itenez, frontier with Mato Grosso (SW1360), Peña \& Foster 237 (K).

Paraguay. Paraguari: Ybycui (SW2656), Zardini 4960 (K, MO).

In the Flora Neotropica account (Pennington et al., 1981), a few collections from Amazonian Peru were included in this subspecies (Killip \& Smith 26793 (F), Gentry et al. 18858 (MO), Schunke 6895 (MO)). These possibly represent a distinct species or a form of Guarea macrophylla subsp. pachycarpa. No further collections of this plant have been made, and they remain doubtful and are excluded from the distribution map of the subspecies.

28c. Guarea macrophylla subsp. spiciflora (A.Juss.) T.D.Penn. in T.D.Penn. et al., Fl. Neotrop. 28: 287, fig. 58 (1981). - Guarea spiciflora A.Juss. in St.Hil., Fl. Bras. Mer. 2: 81 (1829), as 'spicaeflora'. - Type: Brazil, Rio de Janeiro, banks of the Parahyba (Paraiba) River, fl., St. Hilaire s.n. (holo P). Figs 22, 51C.

For synonymy see T.D.Penn. in T.D.Penn. et al., Fl. Neotrop. 28: 287-288 (1981).

Leaflets nearly always oblanceolate, apex attenuate to rounded, glabrous, without red papillae, secondary veins usually convergent, leaves with a non-active terminal bud, inflorescence a short, laxly-flowered, slender, \pm unbranched thyrse, 10$15(-20) \mathrm{cm}$ long, petals 5.5-7.5 mm long, anthers $(0.8-) 1-1.25 \mathrm{~mm}$ long, fruit $0.75-1.25(-1.5) \mathrm{cm}$ long, \pm globose, usually smooth, sparsely and minutely puberulous, valves usually 1 -seeded.

Distribution and ecology. Paraguay and northern Argentina, and extending into southeast Brazil, in seasonally dry cerrado and gallery forest.

Representative additional collections. BraziL. Mato Grosso do Sul: Porto Murtinho, Fazenda Taruma (SW2157), Hatschbach et al. 76556 (K). Minas Gerais: Marlieria, Parque Estadual do Rio Doce (SW1942), Stehmann et al. 2969 (K).

Paraguay. Alto Paraná: Estancia Río Bonito (SW2554), Zardini \& Guerrero 42693 (K). Caazapa: Estancia Golondrina, Ypeti (SW2555), Zardini \& Hellman 48976 (K). Canindiyu: $34 \mathrm{~km}$ E of Villa Ygatimi, near R. Jejui-mi (SW2455), Gentry et al. 59372 (K). Central: Paraguay River around San Antonio (SW2557), Zardini \& Velazquez 18226 (K). Concepción: Paso Horqueta, Río Aquidaban (SW2357), Zardini \& Tilleria 37437 (K). Cordillera: between Arroyo Yhaca and General Bernadino Caballero (SW2556), Zardini \& Jara 36521 (K). Guaira: Cordillera de Ybytyruzu, road Melgarejo - Antena (SW2556), Zardini \& Velasquez 12177 (K). Itapua: Yacyreta Dam Island Reserve, Ana Cua (SW2756), Zardini \& Gamarra 51888 (K). Misiones: Rio Tebicuary (SW2657), Zardini \& Guerrero 40111 (K). Paraguari: Parque Nacional Ybicui (SW2656), Zardini \& Velazquez 12466 (K). San Pedro: around Rosario (SW2457), Zardini \& Guerrero 56815 (K).

Argentina. Corrientes: Dep. Ituzaingo, Ayo Santa Isabel (SW2757), Vanni \& Radovancich 1006 (K). Misiones: San Ignacio, Teyucuare (SW2755), Krapovichas et al. 44152 (K). 
28d. Guarea macrophylla subsp. pachycarpa (C.DC.) T.D.Penn. in T.D.Penn. et al., Fl. Neotrop. 28: 289, figs 57, 58 (1981). - Guarea trichilioides L. var. pachycarpa C.DC. in Mart., Fl. Bras. 11(1): 184 (1878). - Type: Brazil, Para or Maranhão, fr., Martius s.n. (holo M). Figs 23, 64A.

For synonymy see T.D.Penn. in T.D.Penn. et al., Fl. Neotrop. 28: 289 (1981).

Leaflets variable in shape, \pm glabrous, without red papillae, secondary veins convergent or parallel, leaves with a dormant non-active terminal bud, inflorescence a short densely-flowered to long slender laxly-flowered thyrse to $30 \mathrm{~cm}$ long, usually unbranched, petals $6-8 \mathrm{~mm}$ long, anthers $0.75-1(-1.25) \mathrm{mm}$ long, fruit $1.5-2.5(-3) \mathrm{cm}$ long, usually fig-shaped and tapering to base, usually smooth, less frequently torulose or costulate, papillose or puberulous, valves with 1-2 superposed seeds.

Distribution and ecology. Venezuela and French Guiana (not yet recorded from Guyana or Surinam), Amazonian and coastal Brazil, Amazonian and Pacific Ecuador, Amazonian Peru and Bolivia. Not yet recorded from Colombia. A tree of lowland rain forest on both non-flooded and periodically flooded land, up to $800 \mathrm{~m}$ altitude in Bolivia.

Representative additional collections. Venezuela. Bolívar: Municipio Raul Leoni, Rio Karun (NW0563), Fernandez 4650 (K). Territorio Federal Amazonas: Misión Rio Mavaca (NW0165), Stergios et al. 15215 (K).

French Guiana. Rivière Compte, 75 km S of Cayenne (NW0452), Oldeman 1221 (K, U).

ECuAdor. Esmeraldas: Anchayacu, Eloy Alfaro, Mayronga (NW0079), Pennington et al. 14937 (K). Pastaza: 25 km NW of Curaray, Pozo Petrolero 'Golondrina' (SW0177), Rubio \& Gudiño 183 (K).

Peru. Amazonas: Bagua Province, Imaza (SW0478), Diaz et al. 4180 (MO). Loreto: Yanomono Explorama Tourist Camp (SW0372), Gentry et al. 31531 (K). Madre de Dios: Prov. Manu, Rio Manu, Cocha Cashu (SW1171), Nuñez et al. 14821 (F). Pasco: Palcazu valley, Otto Frantzen's new rozo (SW0968), Hartshorn et al. 2628 (K).

Brazil. Acre: Municipio Marechal Taumaturgo, R. Jurua, Reserva Estrativista do Alto Jurua (SW0972), Daly et al. 7625 (K). Alagoas: Municipio Murici, Fazenda Amora (SW0935), Kallunki et al. 361 (K, NY). Amazonas: Rio Uatuma, near mouth of R. Pitinga (SW0257), Cid et al. 781 (K). Bahia: Municipio Jussari, road Jussari to Palmeira (SW1539), Jardim et al. 1732 (K). Rondonia: Municipio Alvorada do Oeste, INCRA lines (SW1162), Cid Ferreira 8961 (K).

Bolivia. Beni: Prov. General Jose Ballivián, San Borja to San Ignacio (SW1466), Pennington et al. 13478 (K). La Paz: Iturralde, Santa Fe Tacana, Bourdy 1823 (K). Santa Cruz: Velasco Province (SW1460), Barker \& Thompson 13 (K).

28e. Guarea macrophylla subsp. pendulispica (C.DC.) T.D.Penn. in T.D.Penn. et al., Fl. Neotrop. 28: 290, fig. 57 (1981). - Guarea pendulispica C.DC. in Herzog, Feddes Repert. 7: 59 (1909). - Type: Bolivia, Cunucu, fl., Herzog 313 (holo G). Figs 23, 64B. For synonymy see T.D.Penn. in T.D.Penn. et al., Fl. Neotrop. 28: 290 (1981).

Leaflets variable in shape, glabrous, without red papillae, secondary veins usually \pm parallel, leaves with a dormant non-active terminal bud, inflorescence unbranched, to $50 \mathrm{~cm}$ long, a slender densely-flowered thyrse, petals $6.5-8 \mathrm{~mm}$ long, anthers $0.7-1 \mathrm{~mm}$ 
long, fruit $1.5-2.5 \mathrm{~cm}$ long, usually globose and abruptly contracted into a short stipe, less frequently tapering in the lower half, usually smooth, sometimes wrinkled or obscurely ribbed on drying, sparsely puberulous or papillose, valves usually 1 -seeded.

Distribution and ecology. Costa Rica and Panama to Venezuela and Guyana, Colombia and Ecuador (both Pacific and Amazonian drainage), Amazonian Peru, Bolivia and Brazil (including coastal Brazil). A small tree of non-flooded rain forest, often along riverbanks and occasionally in periodically flooded forest.

Representative additional collections. Costa Rica. Limón: Cordillera de Talamanca, Matina (NW1083), Herrera 2160 (CR, K). San José: Carara Biological Reserve, Bijagualito (NW0984), Zúniga 524 (INB, K).

Panama. Darién: Parque Nacional de Darién, Rio Pucuro (NW0877), Nevers et al. 8386 (K).

Colombia. Antioquia: Municipio Anori, Anori to Dos Bocas, km 1-9 (NW0775), Callejas et al. 8694 (K). Guajira: Municipio Rio Nacha, Tomarrazon (NW1173), Marulanda \& Betancur 2183 (K). Valle: Municipio Caicedonia, $7 \mathrm{~km} \mathrm{~N}$ of Caicedonia (NW0475), Silverstone-Sopkin \& Paz 6783 (K).

Venezuela. Amazonas: Rio Casiquiare, 2 hours from Pacibo (NW0267), Colella et al. 2035 (K). Sucre: Rio Guayabo junction with Rio Zumbador (NW1064), Davidse \& Gonzalez 19280 (K). GuYana. Rupunumi District, Kuyuwini Landing (NW0259), Jansen-Jacobs et al. 2487 (K, U). Ecuador. Los Rios: Puerta Negra, Cerro Samama, Hacienda Clementina (SW0179), Stahl \& Cornejo 6149 (K). Orellana: Rio Tiputini, Yasuni Scientific Station (SW0076), Villa \& Velez 1085 (K). Sucumbios: Cantón Lago Agrio, Cuyabeno Reserve (SW0075), Palacios et al. 7904 (K). Zamora-Chinchipe: $30 \mathrm{~km}$ NE of Zamora (SW0378), Pennington \& Tenorio 10737 (K).

Peru. Huánuco: Pachitea, Codo de Pozuzo (SW0975), Foster 9275 (K). Madre de Dios: Tambopata, Infierno, Hermosa Chica (SW1269), Alexiades et al. 450 (K). Pasco: Palcazu Valley, Marcial Espiritu's land (SW0968), Hartshorn et al. 2769 (K). Ucayali: Pucallpa-Tingo Maria km 86, Alexander von Humboldt Reserve (SW0875), Maas et al. 4487 (NY).

Brazil. Acre: Municipio Rio Branco, Parque Zoobotanico (SW0967), Figueiredo 42 (NY). Amazonas: Rio Uatuma, between Cachoeira Morena and Balbina (SW0257), Cid et al. 109 (K). Bahía: Municipio de Itabuna, Jucari to Palmeira km 9 (SW1539), Callejas et al. 1575 (K). Goias: Municipio Serranapolis, Poussada dos Araras (SW1851), Alvarenga et al. 1273 (K). Pará: Parque Nacional de Tapajós (SW0455), Silva \& Rosario 3940 (K).

Bolivia. Cochabamba: Chaparé, km 18 road to El Palmar (SW1665), Wood 12914 (K). La Paz: Prov. Sud. Yungas, Alto Beni, Reserva Mocatene de Santa Ana (SW1567), Seidel et al. 2877 (K). Santa Cruz: 2 km N of Yapacani (SW1763), Daly \& Balick 2114 (K).

29. Guarea pendula R.S.Ramalho, A.L.Pinheiro \& T.D.Penn., Revista Arvore 11: 185 (1987). - Type: Brazil, Minas Gerais, Viçosa, Mata de Silvicultura, Universidade Federal de Viçosa [SW2042], f1., xii 1983, Ramalho \& Pinheiro 2876 (holo VIC n.v.; iso K, RB n.v.). Figs 24, 51D.

Guarea luciae Barreiros, Albertoa 1: 70 (1987), syn. nov. - Type: Brazil, Minas Gerais, Viçosa, Mata de Silvicultura UFV, fl., Ramalho \& Pinheiro 2876 (holo RB n.v.; iso K, VIC n.v.).

Guarea penningtoniana A.L.Pinheiro, Revista Ceres 38(216): 138 (1991), syn. nov. - Type: Brazil, Espirito Santo, Linhares, Reserva Florestal de Linhares, Companhia Vale do Rio Doce [SW1939], fl., Folli 635 (holo CVRD n.v.; iso K, VIC n.v.). 


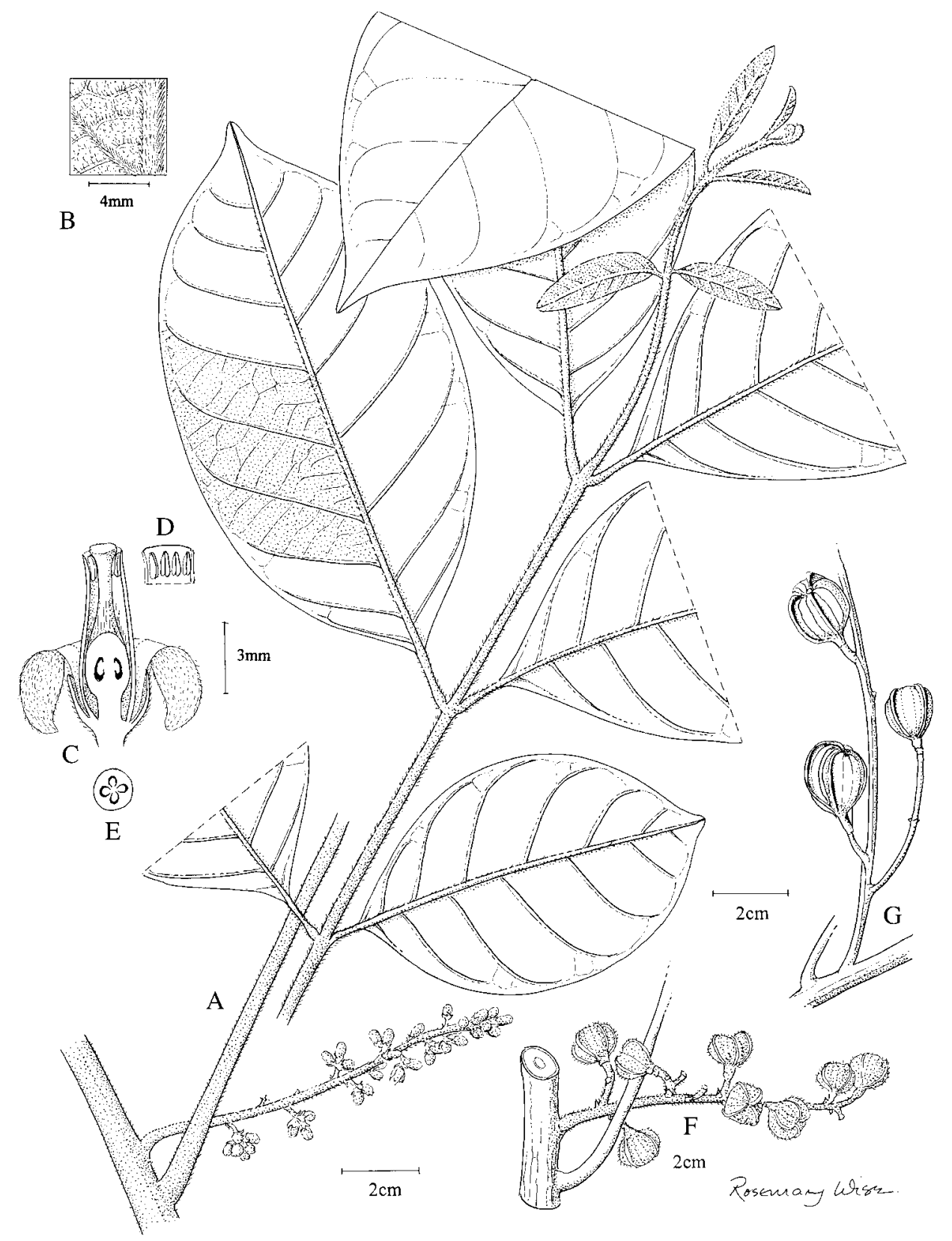

FIG. 24. Guarea pendula R.S.Ramalho et al. A, habit; B, enlargement of leaf undersurface; C, half-flower; D, detail of staminal tube; E, cross-section of ovary; F, young infructescence; G, mature infructescence. (A, B, Ramalho \& Pinheiro 2876; C-E, Folli 700; F, Mexia 4555; G, Lopes \& Andrade 502). 
Young shoots golden-tomentose, 5-8 $\mathrm{mm}$ diam., eventually becoming glabrous, brown and suberous. Leaves pinnate with a terminal bud showing intermittent growth, petiole $4-15 \mathrm{~cm}$ long, semiterete at the base to terete at the apex, pubescent, rhachis up to $35 \mathrm{~cm}$ long, terete or slightly channelled above, pubescent; petiolule 5-10 mm long, pubescent. Leaflets up to 7 pairs, $10.5-21 \times 4-8.3 \mathrm{~cm}$, elliptic to oblanceolate, apex obtusely cuspidate to narrowly attenuate, base acute to narrowly attenuate, chartaceous, upper surface glabrous, but with numerous minute raised dots, lower surface with tomentose midrib and veins and softly pubescent lamina, the hairs intermixed with numerous minute red papillae, not glandular-punctate or -striate; venation eucamptodromous, midrib sunken on the upper surface, secondaries 6-10 pairs, ascending, arcuate, slightly to strongly convergent, intersecondaries short or absent, tertiaries few, oblique. Inflorescence axillary and on twigs below the leaves, up to $30 \mathrm{~cm}$ long and with indeterminate apical growth, a slender thyrse with a few lateral branches in the lower half to $7 \mathrm{~cm}$ long, pubescent to tomentose, flower clusters subtended by small ovate bracts 1-2 mm long; pedicel c. $1 \mathrm{~mm}$ long. Calyx cyathiform, 2.5-3 mm long, 4-lobed to halfway or more, lobes ovate, pubescent outside, glabrous inside. Petals 4, valvate, c. $8 \times 2 \mathrm{~mm}$, strap-shaped, apex acute, appressed pubescent outside, glabrous inside. Staminal tube c. $7 \times 1.5 \mathrm{~mm}$, margin truncate, glabrous; anthers 8, c.1.25 mm long, glabrous, dehiscent. Nectary 1$1.25 \mathrm{~mm}$ long, a stout stipe supporting the ovary, glabrous. Ovary 2-2.5 mm long, ovoid, 4-locular, locules 1-ovulate, densely long-strigose, style 2-2.5 mm long, glabrous, style-head discoid, equalling the anthers. Capsule 1.5-2 cm long, c. $1.5 \mathrm{~cm}$ broad, broadly pyriform, apex truncate, base tapering to a short stipe, 4-valved, each valve shallowly 3-costate, pubescent, becoming sparser with age, valves 1-seeded. Seeds c. $1.5 \times 1 \mathrm{~cm}$, surrounded by a red sarcotesta.

Field characters. Tree to $15 \mathrm{~m}$ high and $20 \mathrm{~cm}$ diam., bark fissured and scaling in small plates, flowers cream-coloured, capsule maturing dark red, and seeds with a red sarcotesta. Flowering recorded in December and March, mature fruit in August.

Distribution and ecology. Minas Gerais and Espirito Santo, Brazil in Atlantic coastal rain forest and in drier semideciduous forest around Viçosa, up to $700 \mathrm{~m}$ altitude.

Collections examined. BRAZIL. Minas Gerais: Caratinga Biological Station (SW1942), Lopes \& Andrade 502 (K).

Local names. Cedro baio (Espirito Santo), tauba, cura madre (Minas Gerais).

In its morphology Guarea pendula belongs in the group of species containing G. guidonia, G. macrophylla and G. pubescens, which are all characterised by small flowers with 4 petals, 8 anthers, and 4-locular ovary with 1-ovulate locules. It is perhaps closest to Guarea macrophylla but differs from it in the uniformly pubescent lower lamina, and generally smaller, obscurely ribbed fruit which is not tuberculate. However, the phylogenetic analysis places it next to Guarea gracilis and G. blanchetii (all from coastal Brazil). 
30. Guarea blanchetii C.DC. in Mart., Fl. Bras. 11(1): 187 (1878); T.D.Penn. in T.D.Penn. et al., Fl. Neotrop. 28: 357 (1981). - Type: Brazil, Bahía, fl., Blanchet 2324 (holo G-DC; iso G, NY, P). Figs 25, 51E.

Young shoots tomentose with yellowish hairs, soon becoming glabrous and developing a thick suberous and fissured bark, $0.5-1.5 \mathrm{~cm}$ diam. Leaves pinnate with a terminal bud showing intermittent growth, petiole 10-16 cm long, channelled on the upper surface or semiterete, shortly pubescent, rhachis up to $50-60 \mathrm{~cm}$ long, semiterete or slightly channelled above, shortly pubescent; petiolule 4-5 mm long, swollen. Leaflets opposite, $2-13$ pairs, $23-42 \times 8.5-18.5 \mathrm{~cm}$, broadly oblong or elliptic, apex acuminate to obtusely cuspidate, base acute to narrowly attenuate, lowest pair of leaflets much smaller c. $8 \times 5 \mathrm{~cm}$, chartaceous, upper surface glabrous, lower surface with pubescent midrib and veins and with scattered hairs across the lamina, numerous minute red papillae usually present, not glandular-punctate or -striate; venation eucamptodromous, midrib slightly sunken on the upper surface, secondaries 14-16 pairs, ascending, straight or slightly arcuate, parallel or slightly convergent, intersecondaries short or absent, tertiaries oblique and parallel. Inflorescence cauliflorous or ramiflorous, 6-15 cm long, a slender panicle with a few short lateral branches near the base to $3 \mathrm{~cm}$ long, sparsely pubescent; pedicel c. $1 \mathrm{~mm}$ long. Calyx cyathiform, 2.5-3 cm long, deeply and irregularly 4-lobed, lobes broadly ovate, obtuse or rounded, with scattered hairs outside, glabrous inside. Petals 4(-5), valvate, 7-8 $\mathrm{mm}$ long, 2-3 $\mathrm{mm}$ broad, strap-shaped, apex acute, appressed pubescent outside, glabrous inside. Staminal tube c.5 mm long, 1.5-2 $\mathrm{mm}$ broad, margin undulate, glabrous; anthers 8, c.1 mm long, oblong, glabrous, dehiscent. Nectary a short stipe c. $0.5 \mathrm{~mm}$ long, expanded into a collar below the ovary, glabrous. Ovary narrowly ovoid, c. $3 \mathrm{~mm}$ long, 4-9-locular, locules 1-ovulate, appressed pubescent in the lower half, glabrous above, style c. $1.5 \mathrm{~mm}$ long, glabrous, style-head discoid. Capsule 2-2.5 cm long, 2.5-3 cm broad, obovoid, apex truncate or slightly depressed, tapering to an obtuse base and short, broad stipe 1-2 mm long, 4-9-valved, valves with 3 irregular and anastomosing ribs or shallow wings $3-4 \mathrm{~mm}$ high, densely puberulous, pericarp 1-2 mm thick (excluding the wings), valves 1-seeded.

Field characters. Small treelet to $7 \mathrm{~m}$ high and $10 \mathrm{~cm}$ diam., with creamish white to yellow flowers, and pinkish mature capsule. Flowering March to April, mature fruit in July.

Distribution and ecology. Confined to the wet coastal rain forests of Bahía and Espirito Santo, Brazil.

Collections examined. Brazil. Bahía: Municipio de Una, road Olivença - Vila Brasil (SW1439), de Carvalho et al. 678 (K); Municipio de Urucuca, km 7.3 road Serra Grande to Itacaré (SW1439), de Carvalho et al. 3403 (NY); Municipio de Una, Mico-leão Biological Reserve (SW1539), Hage et al. 2374 (K), Jardim et al. 225 (NY); Municipio de Una, km 19 road Sao José de Buerarama to Una (SW1539), Mattos Silva et al. 719 (K); Municipio de Una, Una to Canavieiras km 5 (SW1539), Mattos Silva et al. 740 (K); Municipio Wenceslau 


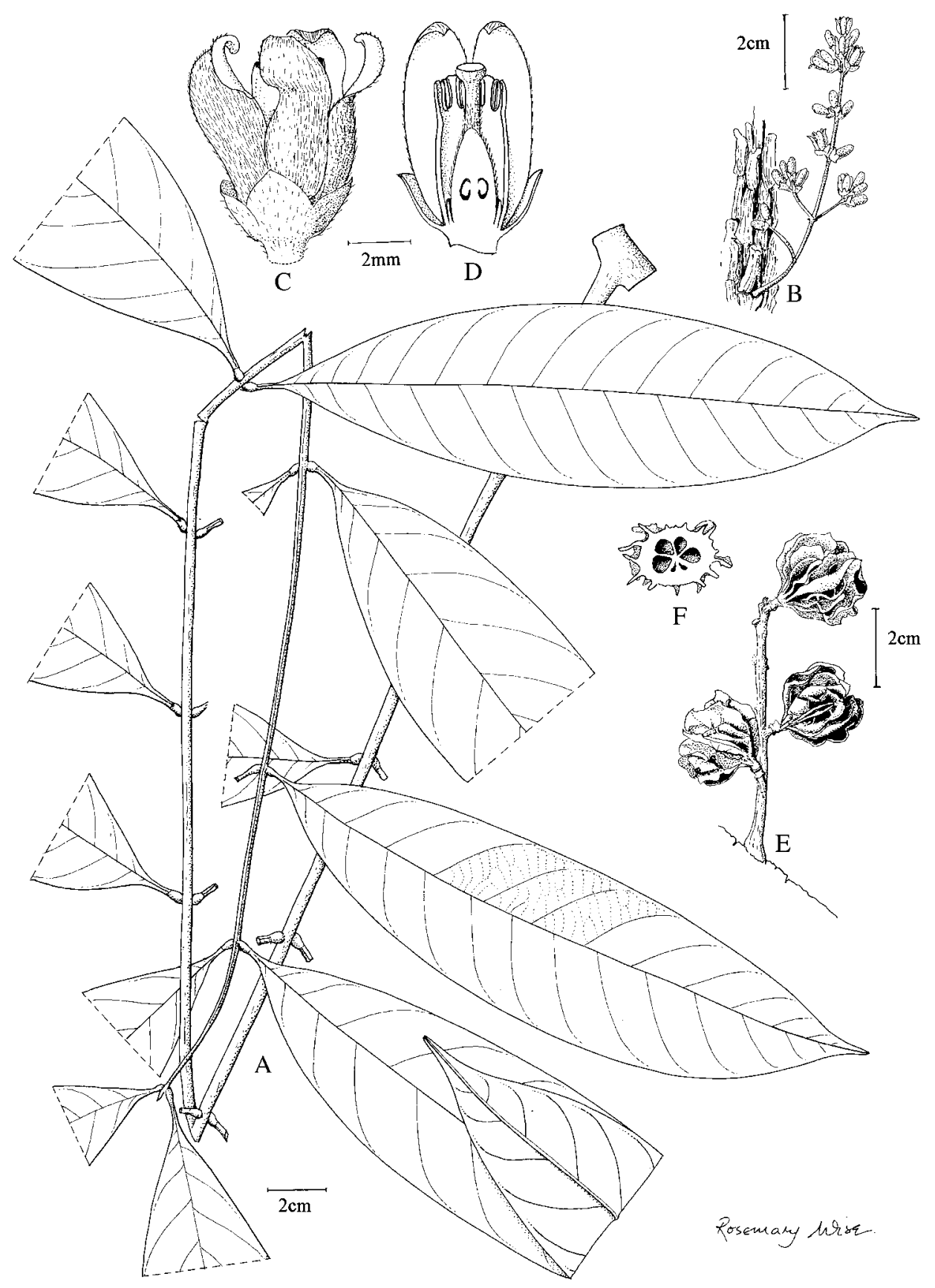

FIG. 25. Guarea blanchetii C.DC. A, habit; B, inflorescence; C, flower; D, half-flower; E, infructescence; F, cross-section of fruit. (A-D, Kallunki et al. 585; E, F, Mattos Silva \& Sant'ana 2933). 
Guimaraes, State Reserve, Mattos Silva et al. 2933 (NY); Municipio de Itacare, $25 \mathrm{~km}$ SE of Ubaitaba (SW1438), Mori \& Carvalho 12009 (K); Municipio Ilheus, 3 km N of Rodoviaria (SW1439), Thomas et al. 10591 (NY); Divisa da Fazenda Maruim com Faz. Dois de Julho, $40 \mathrm{~km} \mathrm{~S}$ of Ilheus (SW1539), Sant'Ana et al. 360 (NY). Espirito Santo: Municipio Rio Bananal, Faz. Lagoa Santa, W of Linhares (SW1940), Kallunki et al. 585 (G, MO, NY).

Local name. Bilveiro-cortica.

The floral structure of Guarea blanchetii is similar to that of many small-flowered species such as G. guidonia, G. convergens and G. macrophylla, with 4 valvate petals, 8 anthers and a 4-locular ovary with 1-ovulate locules. It is however distinctive in its cauliflorous inflorescence, in the variable number of ovary locules and prominently ribbed capsule. The capsule is similar to that of Guarea velutina and G. juglandiformis, but the ribs are shallower, and it also differs from those species in its cauliflorous inflorescence and much larger leaflets. The present delimitation of Guarea blanchetii is problematic, as the ITS phylogeny indicates that it contains a high amount of intraspecific variation, and has G. gracilis embedded within it.

\section{Guarea gracilis T.D.Penn., sp. nov. Figs 26, 51F.}

Guarea macrophyllae affinis sed foliolis gracilioribus, capsula manifeste costata differt. - Type: Brazil, Rio de Janeiro, Rio das Ostras, Uniao Biological Reserve, fr., May 1998, P.P. de Oliveira 344A (holo K; iso BHCB n.v.).

Young shoots sparsely short-pubescent, soon glabrous, smooth, greyish, 2-3 mm diam. Leaves pinnate with a terminal bud showing intermittent growth, petiole 2-4 cm long, semiterete, glabrous, rhachis 7-12.5 cm long, semiterete, glabrous; petiolule c. $3 \mathrm{~mm}$ long, slightly channelled on the upper surface, glabrous. Leaflets opposite, 2-5 pairs, uppermost pair 9-13.5 $\times 2-3 \mathrm{~cm}$, lowermost pair 4-5 $\times 2$ $2.3 \mathrm{~cm}$, narrowly elliptic to elliptic, apex acuminate, base narrowly attenuate, chartaceous, glabrous above, scattered appressed hairs on midrib below and sparse minute red papillae on the lamina, not glandular-punctate or -striate; venation eucamptodromous, midrib sunken on the upper surface, secondaries 6-8 pairs, ascending, arcuate, convergent, intersecondaries moderately long, tertiaries perpendicular to coarsely reticulate. Inflorescence axillary, 8-13 cm long, a very slender panicle with some short lateral branches near the base, few- and lax-flowered, sparsely appressed puberulous. Flowers subtended by small ovate bracts c. $1 \mathrm{~mm}$ long; pedicel c. $1 \mathrm{~mm}$ long. (Flower buds only seen.) Calyx cup-shaped, c. $1 \mathrm{~mm}$ long, with 4 triangular lobes about 1/3 of its length, sparsely appressed puberulous outside, glabrous inside. Petals 4, c.1.5 mm long (in bud). Staminal tube with 8 anthers in the throat. Ovary 4-locular, strigose, locules 1-ovulate; style-head discoid. Capsule 1.2$1.5 \mathrm{~cm}$ long, 1.7-2 cm broad, depressed-globose, apex truncate, base obtuse, 4-valved, the valves prominently longitudinally 3-ribbed, the 2 lateral ribs more prominent than the central one, 2-3 mm high, the central rib smaller and shallower, pericarp c. $1.5 \mathrm{~mm}$ thick (between the ribs), sparsely puberulous; each valve with a solitary seed, c.1.1 $\times$ $0.8 \mathrm{~cm}$, shaped like the segment of an orange, completely surrounded by a thin fleshy 


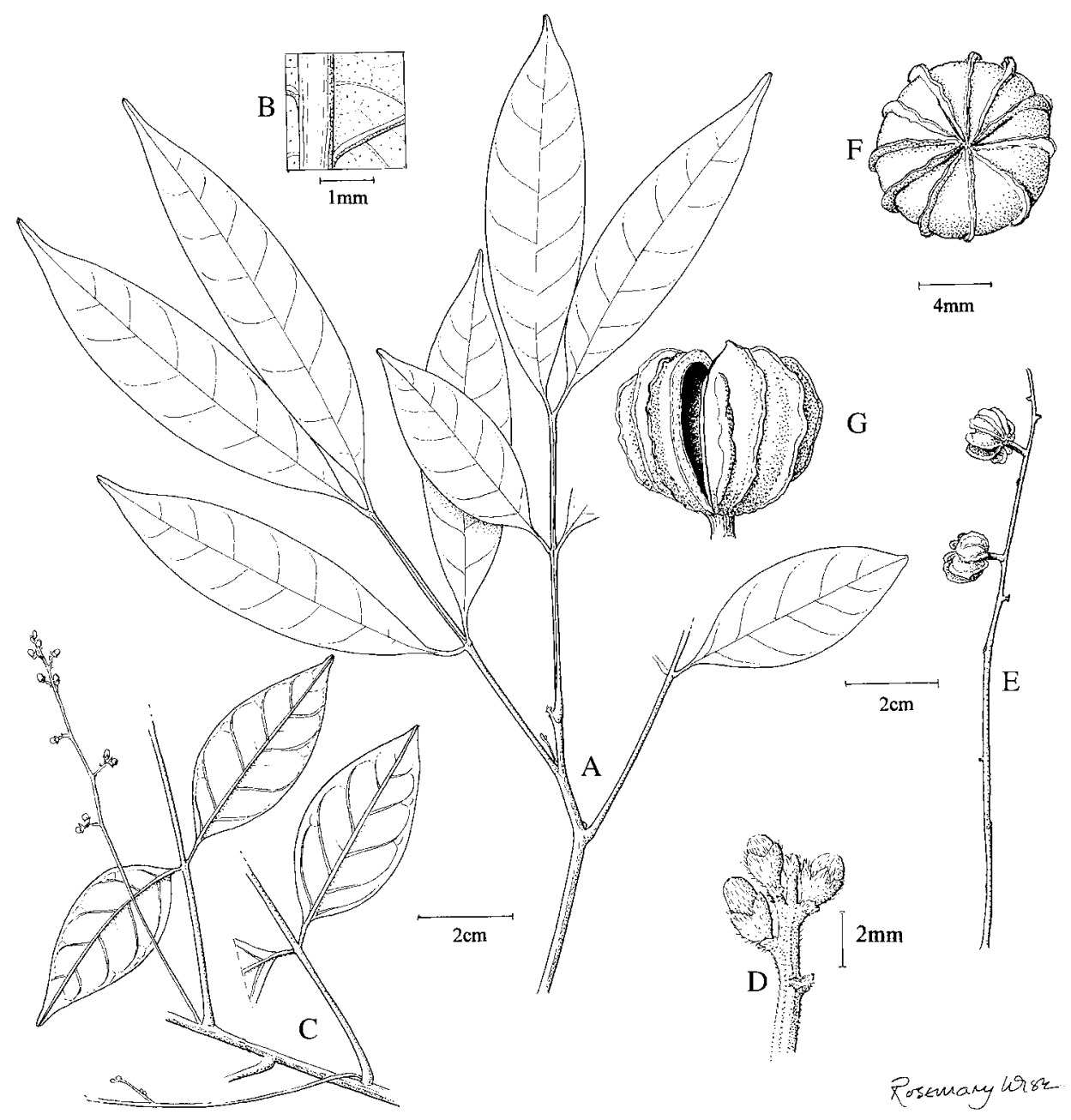

FIG. 26. Guarea gracilis T.D.Penn. A, habit; B, enlargement of leaf undersurface; C, inflorescence; D, flower buds, E, infructescence; F, fruit. (A-D, Oliveira 647B; E, F, Oliveira 344A).

sarcotesta. Seed coat thin and fleshy; embryo with plano-convex, superposed cotyledons, radicle abaxial, extending to the surface; endosperm absent.

Field characters. A small understorey treelet with dark red fruit. Young flowers collected in November and December, fruit in May, July and September.

Distribution and ecology. In wet hill forest in Rio de Janeiro and Espirito Santo, Brazil.

Collections examined. Brazil. Espirito Santo: Linhares, Linhares Forest Reserve (SW1939), Folli 1427 (K). Rio de Janeiro: Rio das Ostras, União Biological Reserve (SW2141), de Oliveira 65E (K), $647(\mathrm{~K}), 647 \mathrm{~B}(\mathrm{~K})$. 
Morphologically closest to Guarea macrophylla and $G$. pendula, but clearly distinct on the basis of the slender leaflets with few (6-8) secondary veins, and the small depressed-globose capsule with prominent longitudinal ribs. The flowers have the same basic structure as those of Guarea macrophylla, but are probably smaller (flowers seen only in bud). This relationship is supported by the ITS phylogeny.

One further collection from Caratinga, Minas Gerais (Horta et al. $316(\mathrm{~K})$ ) probably belongs in this species.

32. Guarea carapoides Harms, Notizbl. Bot. Gart. Berlin-Dahlem 10: 245 (1928); T.D.Penn. in T.D.Penn. et al., Fl. Neotrop. 28: 333 (1981). - Type: Peru, Amazonas, mouth of R. Santiago, fl., Tessmann 4376 (holo B, destroyed; photo F; iso F (fragment)). Figs 27, 53D.

Young shoots massive, 2-3 cm diam., glabrous, dark brown, smooth at first, soon becoming suberous and fissured (bark 3-4 mm thick). Leaves pinnate, petiole 28 $33 \mathrm{~cm}$ long, strongly channelled and winged at the base, glabrous, rhachis $40-50 \mathrm{~cm}$ long, semiterete, glabrous, petiolule c. $1 \mathrm{~cm}$ long, strongly swollen, glabrous, leaflets opposite, 5-7 pairs, 35-38 × 10-11 cm, oblong to oblanceolate, apex acuminate, base acute to rounded, subcoriaceous, glabrous, not glandular-punctate or -striate; venation eucamptodromous, midrib sunken on the upper surface, secondaries 12-16 pairs, ascending, parallel or slightly convergent, mostly straight, intersecondaries absent, tertiaries oblique, fine, numerous. Inflorescence axillary or on twigs below the leaves, 13-30 cm long, a slender panicle with short lateral branches to $1 \mathrm{~cm}$ long, or racemose, minutely puberulous. Flowers subtended by minute bracts; pedicel 1-2 mm long. Calyx cup-shaped in bud, becoming patelliform, 4-5 mm long, c.10 mm wide, margin irregularly lobed and divided, lobes rounded, finely puberulous outside, glabrous inside. Petals 5-6, valvate, c. $1.7 \times 0.3-0.4 \mathrm{~cm}$, strapshaped, apex acute, finely appressed pubescent outside, glabrous inside. Staminal tube c. $1.2 \times 0.5 \mathrm{~cm}$, cylindrical, margin entire, glabrous; anthers $10-12$, c. $1.5 \mathrm{~mm}$ long, oblong, glabrous. Nectary a stout stipe, c. $1.5 \mathrm{~mm}$ long, expanded into a collar below the ovary, glabrous. Ovary ovoid, 9-12-locular, locules with 2 superposed ovules, pubescent, style pubescent, tapering gradually to the discoid stigma. Capsule c.7.5 $\times 5.5 \mathrm{~cm}$, pyriform, apex truncate, tapering to an acute base, 9-12-valved, when dry each valve with a single faint longitudinal rib (probably smooth when fresh), finely puberulous, valves with 1-2 superposed seeds, pericarp $1-1.5 \mathrm{~cm}$ thick. Seed $1-1.5 \mathrm{~cm}$ long.

Field characters. Tree to $14 \mathrm{~m}$ high and $10 \mathrm{~cm}$ diam. Flowers with a red calyx and pinkish corolla. Flowering recorded in July and August, mature fruit in November.

Distribution and ecology. Western Amazonian Brazil, Amazonian Peru and Ecuador in non-flooded lowland rain forest over clay, up to $400 \mathrm{~m}$ altitude.

Collections examined. EcuAdor. Orellana: Yasuní National Park, Maxus road km 20 (SW0076), M. Aulestia \& Grefa 185 (QCNE). 


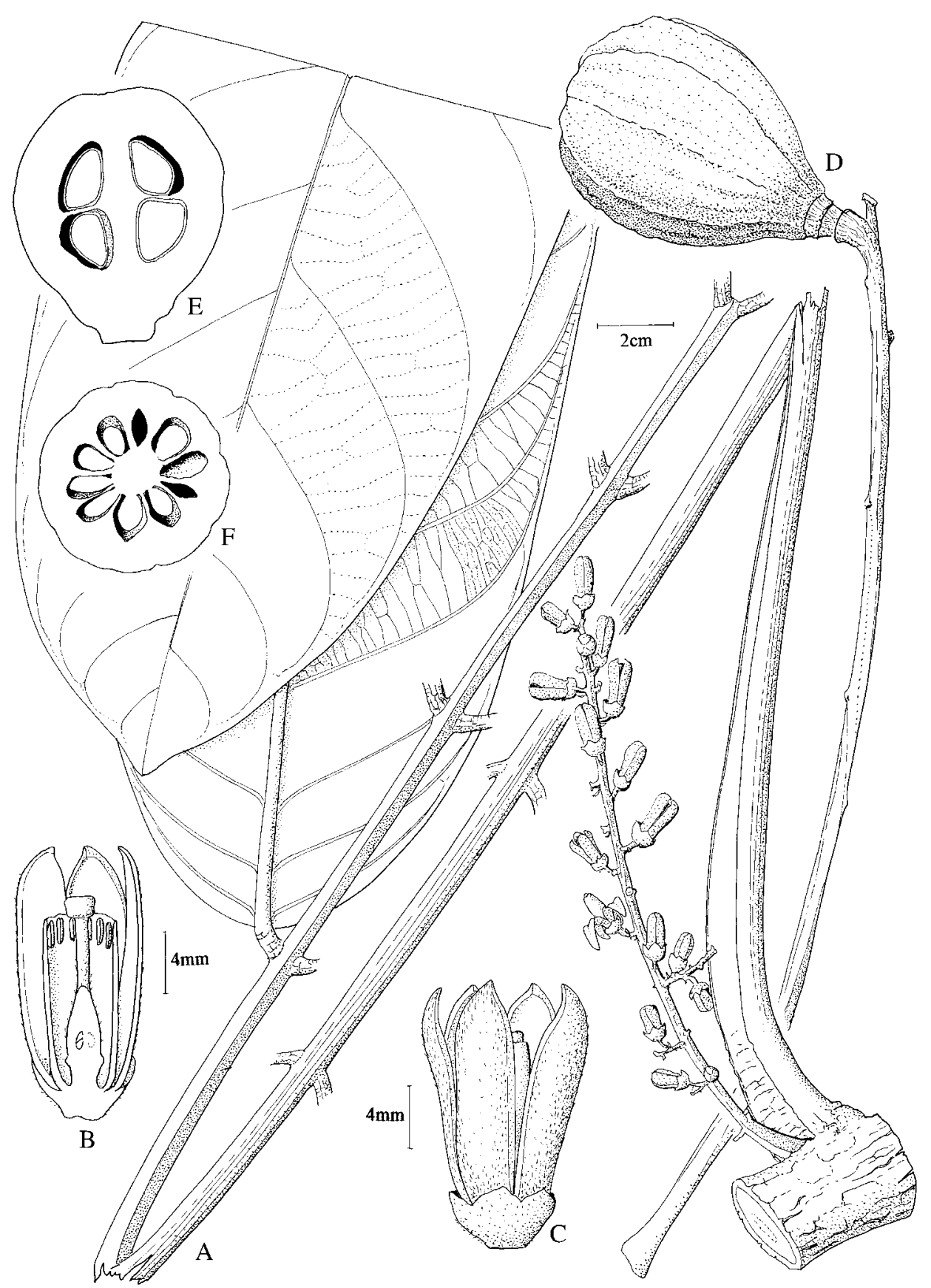

FIg. 27. Guarea carapoides Harms. A, habit; B, half-flower; C, flower; D, fruit; E, longitudinal section of fruit; F, cross-section of fruit. (A-C, Ferreira et al. 5132; D, E, Tunqui 56; F, Berlin 3581). 
Peru. Amazonas: E bank of Santiago River, Galilea (SW0477), Berlin 3581 (MO); Distrito Imaza, Bagua Province, Yamayakat, Diaz et al. 7864 (QCNE); River Cenepa, Huampani (SW0478), Kujikat 317 (MO); Condorcanqui Province, Distrito el Cenepa, Tutino (SW0478), Rojas et al. 45 (F); River Santiago, Caterpiza (SW0377), Tunqui 56 (MO); Alto Amazonas, R. Huallaga, Shucushuyacu (SW0675), Vásquez \& Jaramillo 2454 (MO); Bagua, Yamayakat, track to Putuim (SW0478), Vásquez \& Jaramillo 20267 (K); Distrito el Cenepa, Pagki-Suwa (SW0478), Vásquez et al. 22169 (F).

Brazil. Acre: Municipio Cruzeiro do Sul, BR 364, INCRA Reserve (SW0772), Cid Ferreira et al. $5132(\mathrm{NY})$.

33. Guarea ecuadoriensis W.Palacios, Novon 4: 160, fig. 4 (1994). - Type: Ecuador,

Napo, Coca, Reserva Floristica El Chuncho [SW0077], fl., Palacios 1633 (holo QCNE; iso K, MO). Figs 28, 53E.

Young shoots massive, 1-3 cm diam., densely golden tomentose or velutinous. Leaves pinnate with a terminal bud showing intermittent growth, petiole $18-35 \mathrm{~cm}$ long, massive, strongly channelled and winged at the base, densely tomentose, rhachis up to $1 \mathrm{~m}$ long, strongly channelled, densely tomentose; petiolule swollen, 1-2 cm long. Leaflets opposite, up to 15 pairs, $30-66 \times 10-18 \mathrm{~cm}$, broadly oblong, apex obtuse or obtusely cuspidate, base truncate or slightly cordate, upper surface pubescent along the midrib and veins, lower surface tomentose, indumentum sparser on the lamina, thinly coriaceous, not glandular-punctate or -striate; venation eucamptodromous, midrib sunken on the upper surface, secondaries 25-33 pairs, shallowly ascending, straight, parallel or lowermost slightly divergent, very prominent on the lower surface, intersecondaries mostly absent, tertiaries oblique, often obscure. Inflorescence axillary or in the axils of fallen leaves, a pendulous panicle 30-100 cm long, with a few lateral branches near the base to $20 \mathrm{~cm}$ long, tomentose; pedicel c.1 $\mathrm{mm}$ long above the articulation. Calyx 7-10 $\mathrm{mm}$ long, deeply and irregularly 3-4-lobed to halfway or more, appressed puberulous outside, glabrous inside. Petals 5-6, 18-20 mm long, 3-4 mm broad, strap-shaped, apex acute, palesericeous outside, glabrous inside. Staminal tube 13-15 mm long, 4-5 mm broad, margin entire, glabrous; anthers 13-14, c. $2.5 \mathrm{~mm}$ long, glabrous. Nectary a stout stipe c. $3 \mathrm{~mm}$ long, expanded at the apex. Ovary (male only seen) c. $3 \mathrm{~mm}$ long, ovoid, 7-9-locular, locules with 2 superposed ovules, densely pubescent, style c.7 mm long, sparsely pubescent, style-head broadly discoid, equalling the anthers. Capsule 5-6 $\times$ $3.5-6 \mathrm{~cm}$, broadly oblong to obovoid, apex rounded to truncate, base obtuse or tapering to a short stipe, smooth (slightly ribbed when dry), 7-9-valved, pericarp c. $1 \mathrm{~cm}$ thick, densely tomentose, valves with 2 superposed seeds. Seeds $1.3-2 \mathrm{~cm}$ long; embryo with plano-convex, superposed cotyledons.

Field characters. Tree to $30 \mathrm{~m}$ high, little-branched, the branches with terminal clusters of very large leaves. Flowers with cream-coloured corolla, the margins of the petals sometimes pinkish, fruit maturing red. Flowering in June, mature fruit in September and October. 


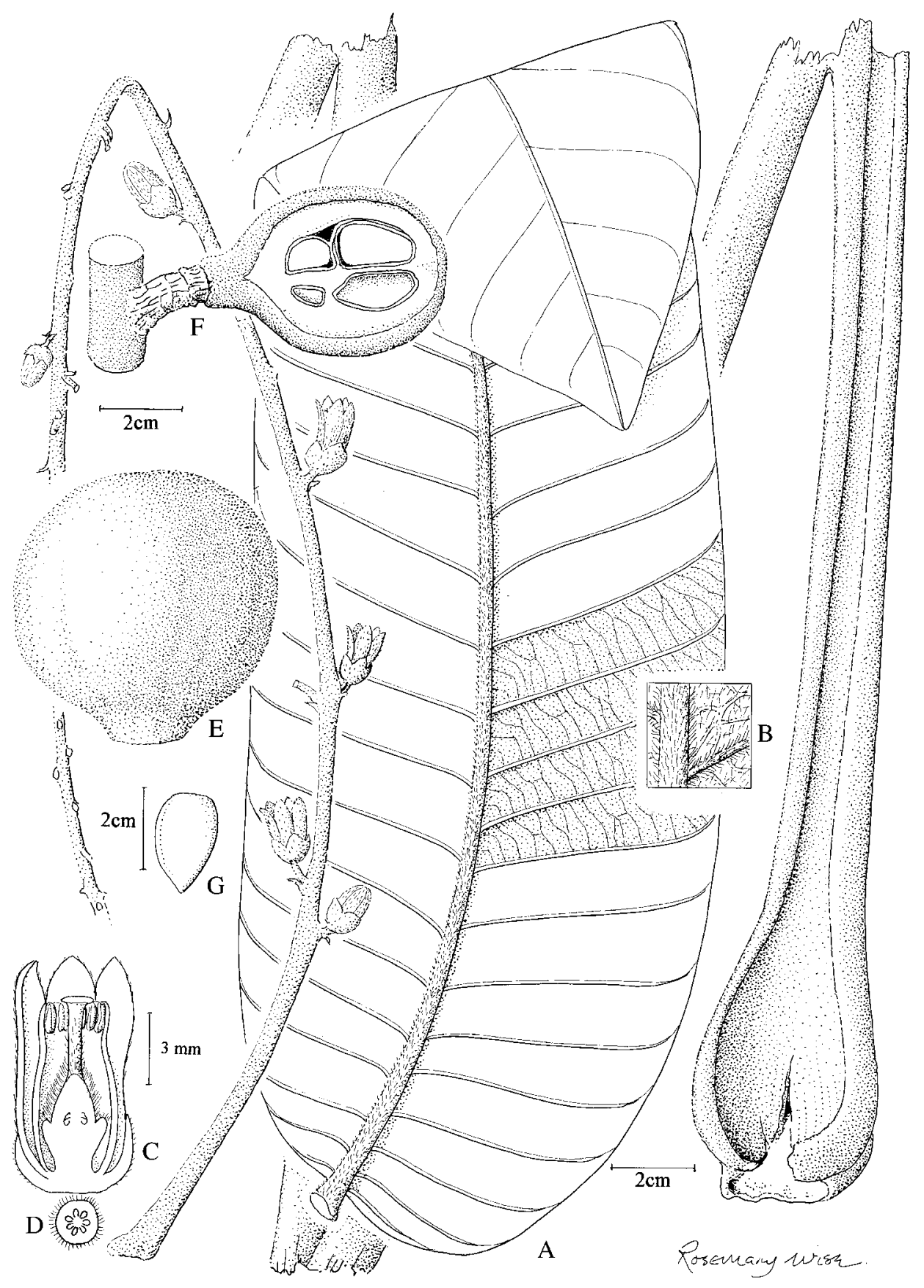

FIG. 28. Guarea ecuadoriensis W.Palacios. A, habit; B, enlargement of leaf undersurface; C, half-flower; D, cross-section of ovary; E, fruit; F, longitudinal section of fruit; $\mathrm{G}$, seed. (A-D, Palacios et al. 1285; E, G, Rudas \& Prieto 3164; F, Vásquez \& Soto 8324). 
Distribution and ecology. Amazonian Colombia, Ecuador and Peru and extreme western Amazonian Brazil. A tree of lowland rain forest on non-flooded land below $400 \mathrm{~m}$ altitude.

Collections examined. Colombia. Amazonas: Leticia, Parque Nacional Natural Amacayacu (SW0370), Rudas \& Prieto 3164 (MO).

EcuAdor. Orellana: Estación INIAP Payamino, Reserva 'El Chuncho' (SW0077), Palacios et al. 1285 (NY, QCNE); $5 \mathrm{~km} \mathrm{~N}$ of Coca, Coca-Payamino road (SW0077), Palacios 3193 (K); Añangu, Yasuní National Park (SW0076), SEF 8728 (K, NY).

Peru. Loreto: Maynas, Quebrada Sucursari (SW0372), Gentry et al. 42655 (AMAZ, K); Maynas, Iquitos-Nauta, km 42 (SW0473), Vásquez \& Soto 8324 (MO); Maynas, Allpahauyo (SW0473), Vásquez et al. 6599 (MO).

BraZIL. Acre: Municipio Cruzeiro do Sul, Seringal São João, Tapauna (SW0972), Daly et al. $7526(\mathrm{~K}, \mathrm{NY})$.

A very distinctive species characterised by the very large leaflets, tomentose indumentum on all parts of the plant and very large flowers. Morphologically it is closest to Guarea grandifolia, but it has larger leaflets with more numerous secondary veins, larger flowers and tomentose fruit. The dense tomentose indumentum is also unusual, though not unknown, in Guarea grandifolia.

34. Guarea fistulosa W.Palacios, Fl. Ecuador 82, Fam. 98, Meliaceae: 25 (2007) (nom. nov.). - Guarea penningtoniana M.E.Morales, Rev. Acad. Colomb. Cienc. Exact. Fis. Nat. 84: 339 (1998), non Guarea penningtoniana A.L.Pinheiro. - Type: Colombia, Guaviare-Caquetá, Parque Nacional Chiribiquete [NW0072], fr., Barbosa et al. 8090 (holo COL; iso COL, K). Figs 29, 54A.

Young shoots finely appressed puberulous at first, soon glabrous, smooth, not scaling, brown, 1.3-1.8 cm diam., hollow. Leaves pinnate with an inactive terminal bud, without intermittent growth, petiole $20-30 \mathrm{~cm}$ long, strongly channelled at the base, semiterete above, subglabrous, rhachis 30-40 cm long, terete, glabrous; petiolule 5-20 mm long, usually swollen. Leaflets opposite, 4-7 pairs, (18-)30$52.5 \times(4.5-) 5.7-13.5 \mathrm{~cm}$, lower pairs often much smaller, oblong or oblanceolate, apex narrowly attenuate, base acute to narrowly cuneate, chartaceous to thinly coriaceous, upper surface smooth, both surfaces \pm glabrous, minute red glandular papillae sometimes present on the lower surface, obscurely glandular-punctate and -striate; venation eucamptodromous, midrib flat or slightly sunken on the upper surface, secondaries 18-28 pairs, ascending, usually straight and \pm parallel, intersecondaries absent, tertiaries oblique, parallel. Inflorescence ramiflorous (on smaller branches), a slender thyrse $4-8 \mathrm{~cm}$ long, lateral branches $<1 \mathrm{~cm}$ long, appressed puberulous, flower clusters subtended by small navicular, ovate bracts $1-1.5 \mathrm{~mm}$ long; pedicel 1-1.5 mm long (above the articulation). Calyx shallowly cup-shaped, 2-3 mm long, irregularly and shallowly 3-5-lobed to halfway, with scattered minute appressed hairs outside, glabrous inside. Petals 4(-5), valvate, 10-13 mm long, 2-3 mm broad, strap-shaped, apex obtuse, free, valvate, sericeous outside, glabrous inside. 


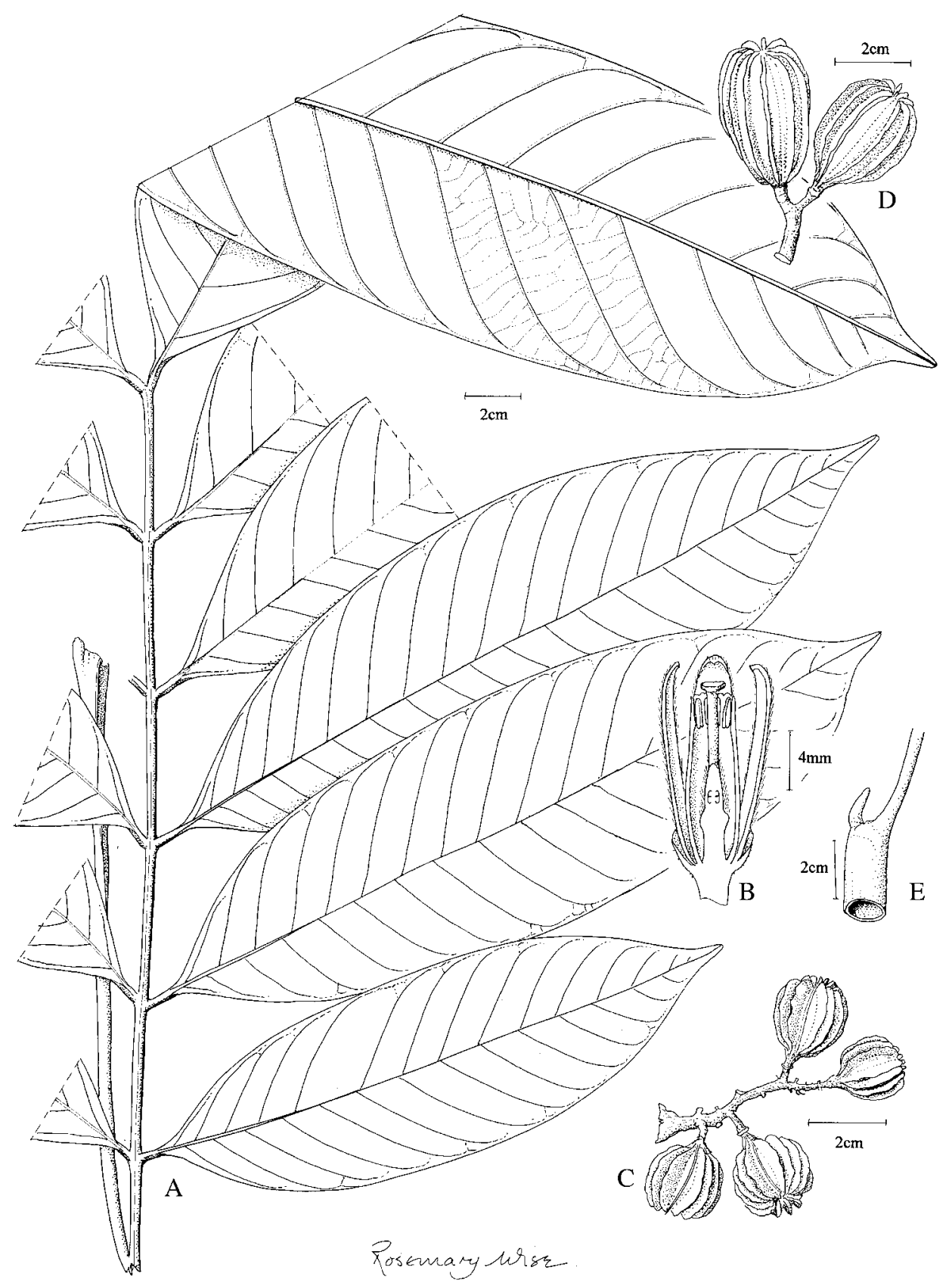

FIG. 29. Guarea fistulosa W.Palacios. A, habit; B, half-flower; C, infructescence; D, mature fruit; E, detail of hollow stem. (A, C, E, Palacios \& Tipaz 9135; B, McPherson 10458; D, Vásquez \& Jaramillo 4710). 
Staminal tube $8 \times 2-10 \times 3 \mathrm{~mm}$, margin undulate, glabrous; anthers 8 , c. $1.5 \mathrm{~mm}$ long, oblong, glabrous. Nectary a stipe below the ovary 1.5-2 mm long. Ovary narrowly ovoid, c. $3 \mathrm{~mm}$ long, 4-5-locular, locules with 2 superposed ovules, densely pubescent, style c.5 mm long, pubescent below, glabrous near the apex, style-head discoid. Capsule $2.5-4 \times 2.3-3 \mathrm{~cm}$, broadly pyriform, apex truncate, base obtuse to rounded, 4-valved, valves with 3 longitudinal undulate ribs, 2-4 mm deep, pericarp 2-3 mm thick (excluding the ribs), shortly velutinous, valves with 1-2 superposed seeds. Seeds c.1.3-1.4 cm long, c. $0.8 \mathrm{~cm}$ broad, truncate at base or apex due to compression, cotyledons plano-convex, obliquely superposed, radicle abaxial, extending to the surface. Seed surrounded by a thin fleshy sarcotesta.

Field characters. Treelet or small tree to $10 \mathrm{~m}$ high, often monocaulous, flowers whitish, fruit maturing red or violet. Flowering recorded in April and June, mature fruit mostly November to January.

Distribution and ecology. Panama, Amazonian Colombia, Ecuador, Peru and western Amazonian Brazil. A small understorey treelet of non-flooded lowland rain forest, below $400 \mathrm{~m}$ altitude.

Collections examined. Panama. Bocas del Toro: above Chiriquí Grande, 10 miles from continental divide (NW0882), McPherson 10458 (MO). ? Colon: Cocle del Norte (NW0980), Hammel 4567 (MO) (included with reservations).

Colombia. Amazonas: Corregimiento de Araracuara, Puerto Arturo (SW0072), AguirreGalviz 922 (COL).

ECuAdor. Orellana: near Puerto Itaya, Indillama (SW0076), Carillo 397 (QCNE); Yasuní National Park, Maxus road km 46 (SW0076), Dik 344 (K); Huaorani Reserve, Miwaguno (SW0076), Freire \& Naranjo 682 (K); Yasuní Scientific Station, Rio Tiputini (SW0076), Romoleroux \& Pitman 2292 (K); Romoleroux \& Villa 2390 (F, K). Sucumbios: Lago Agrio Canton, Cuyabeno Reserve (SW0076), Palacios \& Tipas 9135 (MO, QCNE).

Peru. Amazonas: Bagua Province, Imaza, Yamayakat (SW0478), Jaramillo et al. 359 (F, K); Condorcanqui Prov., Tutino (SW0478), Rojas et al. 56 (QCNE). Loreto: Maynas, Puerto Almendras (SW0373), Acevedo-Rodríguez et al. 1621 (NY); Loreto, Tigre, Rio Tigre, Nuevo Canaan (SW0474), Ayala et al. 2515 (AMAZ, MO); Rio Corrientes, Teniente Lopez (SW0276), Beltran \& Foster 709 (F); Maynas, Rio Yaguasyacu, Borro (SW0371), Gentry \& Revilla 20451 (F, MO); Puerto Almendras, Maynas Province (SW0373), Grandez 2191 (QCNE); Maynas, Allpahuayo (SW0373), Grandez \& Jaramillo 781 (MO); Maynas, Rio Nanay, Caserio Lupuna (SW0373), Revilla 2087 (MO); vicinity of Iquitos (SW0373), Revilla 3668 (F, K, NY), 3690 (K); Maynas, Mazan, Rio Amazonas (SW0373), Rimachi 3050 (K); Iquitos, Puerto Almendras (SW0373), Rueda \& Ruiz 693 (MO); Prov. Requena, (surroundings) (SW0573), Vásquez \& Jaramillo 4710 (K); Maynas, Callicebus Rio Nanay-Mishana Biological Station (SW0373), Vásquez et al. 2809 (MO), Vásquez et al. 18337 (MO).

Brazil. Amazonas: Municipio de São Paulo de Olivença, Bom Fim (SW0368), Cid et al. 8604 (NY); Municipio Labrea, 2-3 km SW of Labrea (SW0764), Prance et al. 7992 (K).

This widespread western Amazonian species has been confused with both Guarea velutina and G. juglandiformis. It differs from both in its stouter hollow twigs, larger leaves and leaflets, numerous (18-28 pairs) \pm straight and parallel secondary veins, 
shorter, ramiflorous inflorescence, longer petals, ovary locules with 2 superposed ovules and capsule valves with narrower, less anastomosing ribs.

There are several other species of Guarea similar to G. fistulosa, but as they are still imperfectly known, we have not yet been able to describe them.

35. Guarea riparia W.Palacios, Novon 4: 158, fig. 3 (1994); W.Palacios, Fl. Ecuador 82, Fam. 98, Meliaceae: 42 (2007). - Type: Ecuador, Zamora-Chinchipe, Punta de Pachicutza, between Pachicutza and Miazi, banks of the R. Nangaritza, fl., Palacios 8444 (holo QCNE; iso MO, QCA). Figs 30, 54B.

Young shoots finely appressed pubescent at first, soon glabrous, $2-4 \mathrm{~mm}$ diam., smooth, greyish brown, with a few lenticels. Leaves pinnate with terminal bud with intermittent growth, petiole $1.5-3.5 \mathrm{~cm}$ long, semiterete, sparsely pubescent, rhachis 4-17 cm long, semiterete, subglabrous; petiolule 4-9 mm long. Leaflets $2-7$ pairs, $6-14.2 \times 0.9-2.8 \mathrm{~cm}$, narrowly elliptic, apex long, slender acuminate, base acute to narrowly attenuate, chartaceous, glabrous, not glandular-punctate or -striate; venation eucamptodromous, midrib not raised on the upper surface, secondaries 7-10 pairs, steeply ascending, arcuate and convergent, intersecondaries short to moderately long, tertiaries obscure, oblique. Inflorescence axillary, 7-22 cm long, a slender many-flowered thyrse with short lateral branches 1-3 cm long, sparsely short-pubescent; pedicel 1-1.5 mm long (above the articulation). Calyx patelliform, $0.5-1 \mathrm{~mm}$ long, shallowly 4-lobed or margin truncate, with scattered minute appressed hairs outside, glabrous inside. Petals 4, valvate, 4-4.5 mm long, c. $1.5 \mathrm{~mm}$ broad, strap-shaped, apex acute, appressed puberulous outside, glabrous inside. Staminal tube 3-3.5 mm long, c.2 mm broad, urceolate, margin undulate, glabrous; anthers 8 , c. $0.75 \mathrm{~mm}$ long, glabrous; antherodes in female smaller, c. $0.5 \mathrm{~mm}$ long, not dehiscent, without pollen. Nectary c. $1 \mathrm{~mm}$ long, a stout stipe expanded below the ovary, glabrous. Ovary ovoid, c. $1.5 \mathrm{~mm}$ long, 4-locular, locules 1-ovulate, puberulous, style (in male) c. $1.5 \mathrm{~mm}$ long, in female c.1 mm long, glabrous, style-head discoid. Capsule $0.9-1 \mathrm{~cm}$ long, $0.9-1.2 \mathrm{~cm}$ broad, depressedglobose, apex truncate, base truncate to obtuse, 4-valved, smooth, subglabrous, pericarp $0.5-1 \mathrm{~mm}$ thick, valves 1 -seeded. Seed 7-8 mm long, plano-convex, radicle abaxial, extending to the surface; endosperm absent.

Field characters. Shrub or small tree 1-8 m high, with the young foliage opening reddish. Flowers with reddish calyx and cream-coloured corolla, fruit maturing reddish. Flowering is recorded mainly from October to December, with mature fruit in February, and October to December.

Distribution and ecology. Known only from the frontier region of southern Ecuador with northern Peru, where it is confined to rocky riverbanks in lowland and montane rain forest, ascending to $1000 \mathrm{~m}$ altitude. It is resistant to periodic inundation during flash floods, and often present in dense stands. 


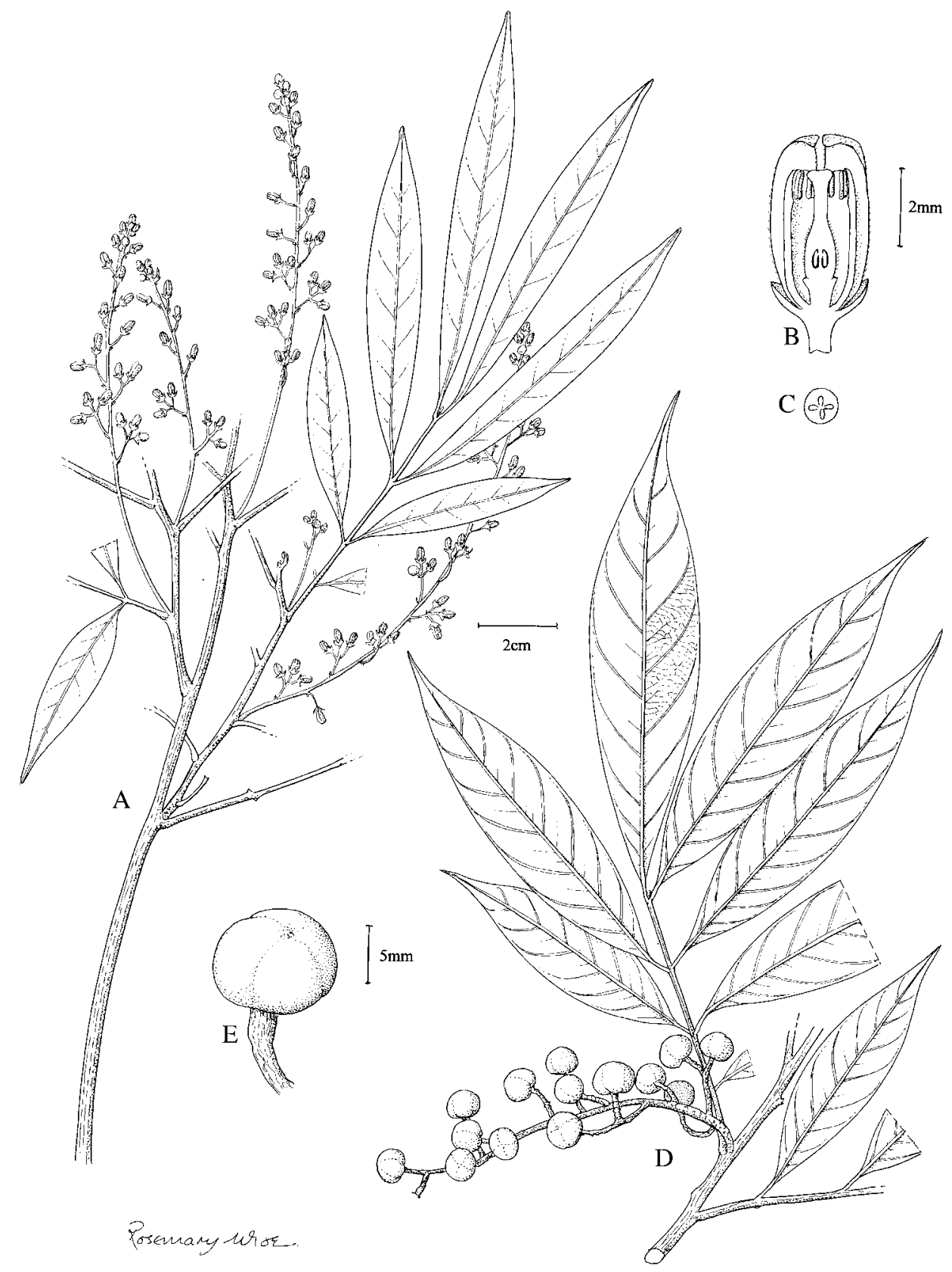

FIG. 30. Guarea riparia W.Palacios. A, habit; B, half-flower; C, cross-section of ovary; D, infructescence, E, fruit. (A-C, Palacios 8460; D, E, Vásquez et al. 19026). 
Collections examined. ECUADOR. Zamora-Chinchipe: Cantón Nangaritza, Destacamento Militar Shaime (SW0478), Jaramillo 13425 (NY), 14165 (MO, NY, QCNE); Rio Nangaritza, between Pachicutza and Miazi (SW0478), Palacios 6613 (K, MO), 6617 (K, QCNE), 8439 (K, MO), 8460 (QCNE).

Peru. Amazonas: $5 \mathrm{~km} \mathrm{~N}$ of confluence of Huampani and Cenepa (SW0478), Berlin 237 (F, MO); Rio Comaina, near Puesto Comando Chavez Valdivia (SW0478), Ferreyra 19471 (MO, US), 19474 (US); Condorcanqui Province Rio Comaina, between Cusu-Kubaim and Chavez Valdivia (SW0478), Vásquez et al. 19026 (K, QCNE); Distrito el Cenepa, Huampani, Suiva (SW0478), Vásquez et al. 22627 (F); Distrito el Cenepa, San Antonio (SW0478), Vásquez et al. 24055 (F).

The ITS phylogeny confirms the close morphological relationship of this species with Guarea guidonia, G. persistens and other small-flowered Amazonian species sharing a similar floral formula: 4 petals, 8 anthers, ovary 4-locular with 1-ovulate locules and small globose fruit. It differs from all these species in its slender narrowly elliptic leaflets which are 5-6 times as long as broad and in its unique ecology.

36. Guarea pyriformis T.D.Penn. in T.D.Penn. et al., Fl. Neotrop. 28: 278, fig. 56 (1981). - Type: Costa Rica, Puntarenas, Canton de Osa, near Palmar Norte de Osa, fl., Allen 5501 (holo K; iso A, F, G, NY, US). Fig. 54C.

Abbreviated description. Twigs often with pale, fissured, suberous bark, indumentum of young shoots and inflorescences pale yellowish tomentose or pubescent, persistent, leaves with indeterminate apical growth, with 2-7 pairs of leaflets, leaflets $14-20(-25) \times$ 4-6.5(-7.5) cm, oblong, oblanceolate or narrowly elliptic, with some pubescence below, secondary veins 13-16 pairs, inflorescence ramiflorous, $4.5-17 \mathrm{~cm}$ long, a slender densely-flowered thyrse, petals 4-5, valvate, 10-11 mm long, densely appressed pubescent or sericeous, staminal tube $8-8.5 \mathrm{~mm}$ long, $2.5-3 \mathrm{~mm}$ broad, anthers $9-10$, ovary 4-5-locular, pubescent, locules 1-ovulate, capsule $2.3-3 \mathrm{~cm}$ long, shortly pyriform, 4-5-valved, smooth, minutely puberulous, pericarp 2-4 mm thick, valves 1 -seeded.

Distribution and ecology. Pacific drainage of southern Costa Rica, Panama and western Colombia, where it is a tree of lowland rain forest, often along streams, up to $500 \mathrm{~m}$ altitude.

Additional collections examined. Costa Rica. Puntarenas: Parque Nacional Manuel Antonio, Punta Catedral (NW0984), Harmon 33 (CR, K, MO).

Panama. Panamá: Llano-Carti road, 7 miles from Pan-Am highway (NW0979), McPherson \& Merello 8204 (K); El Llano-Carti road, 12.7 km from Inter American highway (NW0979), Mori \& Kallunki 4695 (K). San Blas: El Llano-Carti road, 16 km N of Panamerican highway (NW0979), Folsom 2619 (K, MO).

Colombia. Antioquia: Municipio de San Carlos; ISH hydroelectric dam (NW0675), McPherson 13319 (MO); Rio Claro, Alto Rico (NW0575), Renteria et al. 2819 (MO); Municipio Anori, Valle del Rio Anori, between Dos Bocas and Anori (NW0775), Soejarto et al. 4134 (MO); San Carlos, El Jordan, embalse de Punchina-ISA (NW0674), Velasquez et al. 182 (MO). Choco: road to Lloro, 1-2 km SE of Yuto, $30 \mathrm{~km} \mathrm{~S}$ of Quibdo (NW0576), Gentry \& Renteria 23803 (MO). Valle: Bajo Calima, road to Juanchaco Palmeras (NW0377), Gentry et al. 48283 (K); Bajo Calima, $15 \mathrm{~km} \mathrm{~N}$ of Buenaventura (NW0377), Gentry et al. 53691 (K, MO); Bajo Calima, Lijal-Gasolina road bifurcation (NW0377), Gentry \& Faber-Lagendoen 62795 (K). 
Although this species is not present in Amazonia, the ITS phylogeny and the morphology place it with species at the top of the Amazonian clade, close to Guarea guidonia, G. persistens and G. gomma. The flowers of all these species are morphologically very close, but Guarea pyriformis differs from them in the yellowish indumentum on the young shoots and in the fine detail of fruit structure.

37. Guarea gomma Pulle, Rec. Trav. Bot. Néerl. 6: 271 (1909); T.D.Penn. in

T.D.Penn. et al., Fl. Neotrop. 28: 291, fig. 53 (1981). - Type: Surinam, Sectie O, fl., fr., $B W 70$ (holo U; iso K, NY). Figs 31, 49D.

Abbreviated description. Indumentum inconspicuous, puberulous, leaves without intermittent terminal growth, all leaflets opening \pm simultaneously, leaflets $6-10(-12)$ pairs, 14-30 × 3-8.5 cm, narrowly oblong or oblanceolate (lower pairs often elliptic), with 12-18 pairs of secondary veins, subglabrous, often drying dark brown below, inflorescence 15-40 cm long, a slender, densely-flowered thyrse, petals 4-6, valvate, 8-12 mm long, staminal tube 6.5-8 mm long, 2-4 mm broad, anthers 8-10(-12), ovary 4-6(-7)-locular, locules with 1-2 superposed ovules, capsule $2.5-4 \times 2.5-3.5 \mathrm{~cm}, 4-6$ valved, globose to shortly pyriform, smooth, densely papillose-puberulous, pericarp 2-4 mm thick, valves 1 -seeded.

Distribution and ecology. Trans-Amazonian from southern Venezuela and the Guianas to Amazonian Colombia, Ecuador, Peru and Bolivia. It is a tree of nonflooded lowland and lower montane rain forest, altitudinal range up to $800 \mathrm{~m}$.

Representative additional collections. GuYANa. Upper Essequibo Region, Rewa River, near Corona Falls (NW0358), Jansen-Jacobs et al. 5745 (K).

Surinam. Tumuc Humac Mts., Talouakem (NW0254), Acevedo-Rodríguez et al. 6045 (K). French Guiana. Saül, Monts la Fumée (NW0353), Boom \& Mori 2219 (K).

EcuAdor. Napo: Puerto Misahualli, Jatun Sacha Reserve (SW0177), Zaruma 791 (NY). Orellana: Rio Tiputini, Yasuní Scientific Station (SW0076), Villa et al. 814 (US). Pastaza: Canton Pastaza, Pozo Petrolero 'Danta 2' de UNOCAL (SW0176), Rubio \& Coba 790 (F). Sucumbios: Gonzalo Pizarro, Pto. Libre, Sinangue (NW0077), Cerón \& Montalvo 20963 (K). Peru. Huánuco: Puerto Inca, Yuyapichis, DANTAS (SW0975), Tello 2233 (K). Loreto: Yanamono Explorama Tourist Camp (SW0372), Gentry et al. 60922 (K).

Brazil. Acre: Municipio Sena Madureira (SW0968), Daly et al. 8197 (K).

Bolivia. Pando: Prov. Madre de Dios, Concesion de Mobil Oil (SW1267), Killeen 4464 (K).

38. Guarea persistens W.Palacios, Fl. Ecuador 82, Fam. 98, Meliaceae: 36, fig. 4 (2007). - Type: Ecuador, Napo, Canton Archidona, slopes of Volcán Sumaco, Hollin-Loreto road km 40 [SW0077], Palacios \& Iguago 4561 (holo QCNE; iso MO). Figs 32, 54D.

Young shoots minutely appressed puberulous, soon glabrous, brown, smooth, with a few pale lenticels, twigs 6-10 $\mathrm{mm}$ diam., hollow. Leaves pinnate with a dormant, non-active, caducous terminal bud, petiole $14-22 \mathrm{~cm}$ long, semiterete, minutely appressed puberulous to glabrous, rhachis $10-38 \mathrm{~cm}$ long, semiterete, glabrous; 


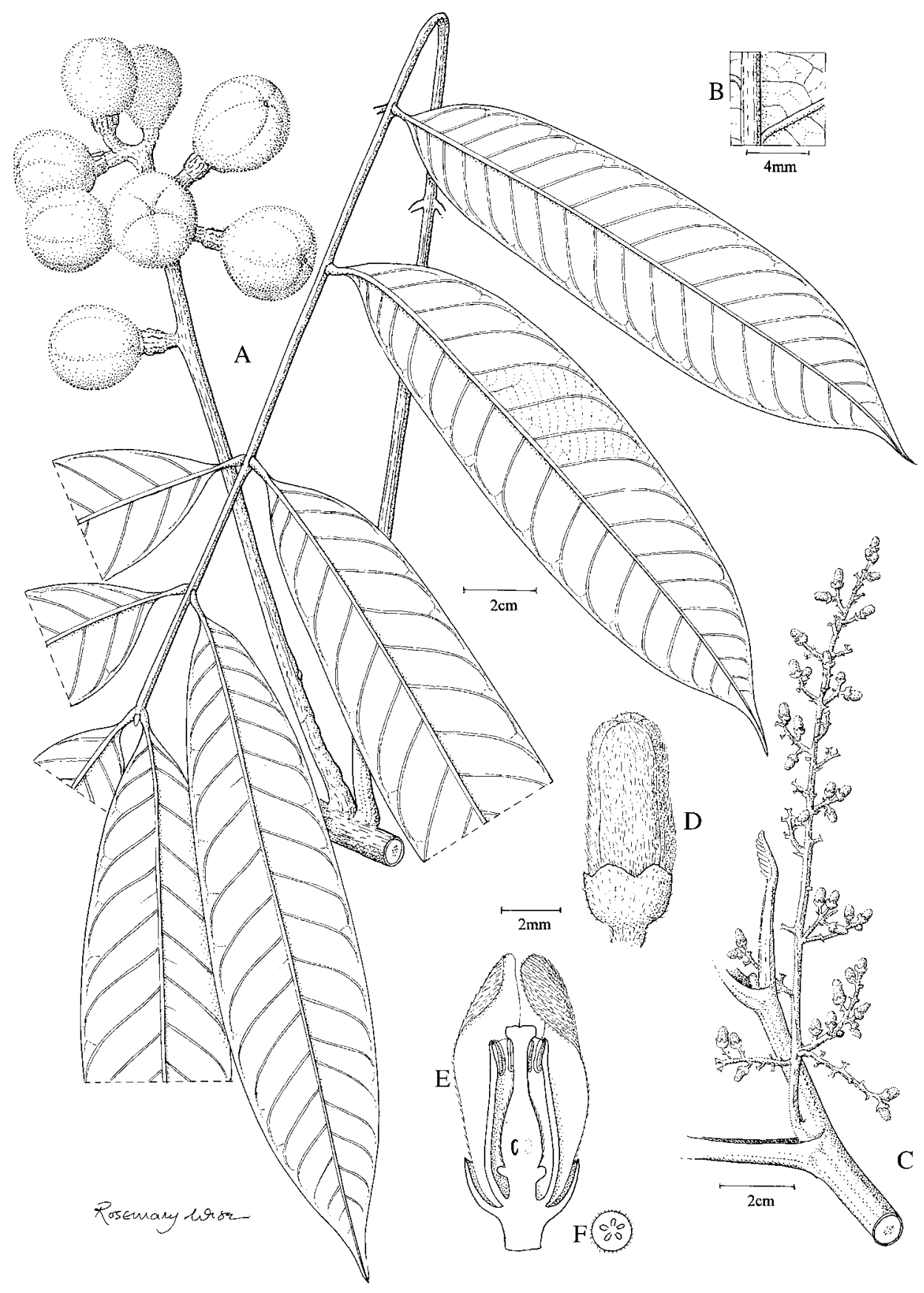

Fig. 31. Guarea gomma Pulle. A, habit; B, enlargement of leaf undersurface; C, inflorescence; D, flower bud; E, half-flower; F, cross-section of ovary. (A, B, Jansen-Jacobs et al. 5745; C-F, Clarke, D. 3625). 


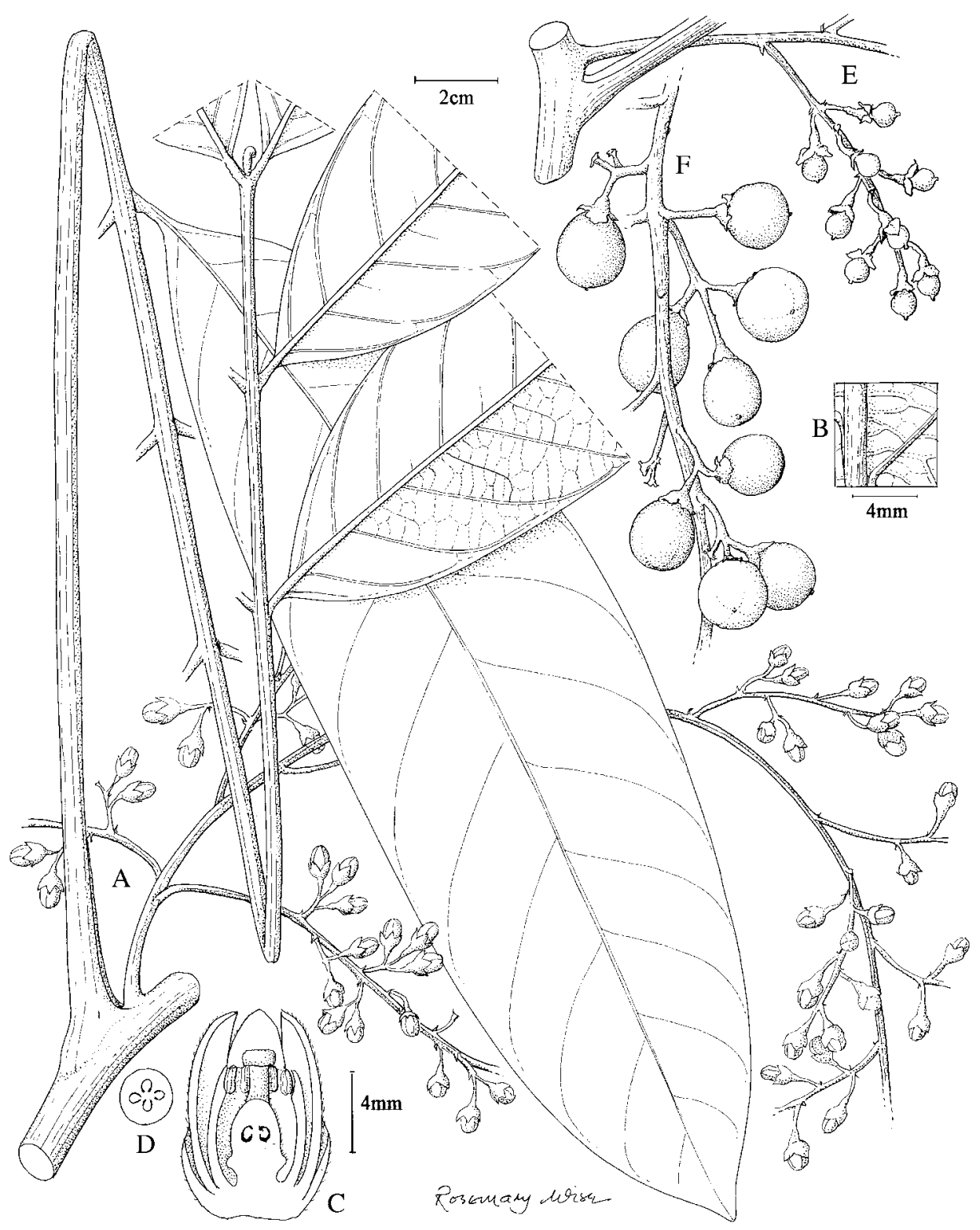

FIG. 32. Guarea persistens W.Palacios. A, habit; B, enlargement of leaf undersurface; C, half-flower; D, cross-section of ovary; E, young infructescence; F, infructescence. (A-D, Clark, L. 2298; E, Palacios 4665; F, Neill et al. 8602).

petiolule 5-10 mm long, swollen in the lower half, glabrous. Leaflets opposite, 5-8 pairs, 17.5-30.5 $\times 4.5-10.5 \mathrm{~cm}$, elliptic, oblong or oblanceolate, apex narrowly acuminate to obtusely cuspidate, base narrowly attenuate to acute, thinly coriaceous, 
glabrous, not glandular-punctate or -striate; venation eucamptodromous, midrib not raised or sunken on the upper surface, secondaries 11-12 pairs, steeply ascending, slightly arcuate and slightly convergent, intersecondaries absent, tertiaries oblique, obscure. Inflorescence axillary or on twigs below the leaves, $10-45 \mathrm{~cm}$ long, a laxlybranched, many-flowered panicle, lateral branches up to $20 \mathrm{~cm}$ long, finely puberulous; pedicel 5-6(-10) $\mathrm{mm}$ long (above the articulation). Calyx closed in bud, cup-shaped, 3-5 mm long, irregularly and deeply 3-4-lobed, lobes ovate, apex acute to obtuse, sparsely appressed puberulous outside; calyx usually persists in fruit. Petals 4-6, valvate, c. $9 \times 2-3 \mathrm{~mm}$, narrowly triangular, acute, finely appressed puberulous outside, glabrous inside. Staminal tube 5-7 mm long, 2.5-3.5 mm broad, shortly tubular, margin undulate or truncate, glabrous; anthers 8-10, c.1.2 mm long, glabrous; antherodes in female not dehiscent, without pollen. Nectary represented by a thick glabrous annulus beneath the ovary. Ovary 2-3 mm long, ovoid, 4(-5)locular, locules 1-ovulate, finely appressed puberulous, style 2-3 $\mathrm{mm}$ long, subglabrous, style-head discoid. Capsule 1.7-2 cm long, shortly pyriform, apex truncate, base obtuse, 4-valved, smooth, finely appressed puberulous, pericarp c. $1 \mathrm{~mm}$ thick. Seed 1 in each valve, shaped like the segment of an orange, completely covered by a thin fleshy sarcotesta.

Field characters. Treelet or small tree to $10 \mathrm{~m}$ high and $15 \mathrm{~cm}$ diam., with hollow twigs inhabited by ants, and flowers with a reddish corolla. The purple or reddish fruit are held in large many-fruited pendulous clusters, and the seed is surrounded by a bright red sarcotesta. Most flowering occurs in March and April, with the fruit maturing September to October.

Distribution and ecology. Amazonian slopes of the Andes in Ecuador in wet montane rain forest from $650 \mathrm{~m}$ to $1300 \mathrm{~m}$ altitude.

Specimens examined. EcuAdor. Napo: Cantón Archidona, slopes of Volcán Sumaco, HollinLoreto road, km 40 (SW0077), Alvarado 38 (K); Parque Nacional Sumaco, Pacto Sumaco (SW0077), Alvarez et al. 1866 (K, NY); Sumaco Napo-Galeras National Park, Pacto Sumaco to Loreto road (SW0077), J.L. Clark 2298 (K, MO, QCNE); Hollin-Loreto, Caserío de Huamani (SW0077), Palacios 4661 (K, MO, NY, QCNE); Cantón El Chaco, Rio Granadillo (SW0077), Palacios 5543 (MO, QCNE); Cantón El Chaco, Codo Sinclair (SW0077), Palacios 5665 (MO, QCNE), 5750 (MO), 5754 (MO), 5768 (MO), 5774 (QCNE); Faldas Sur del Volcán Sumaco, Challua (SW0077), Palacios \& Iguago 4557 (MO, QCNE); Faldas Sur del Volcán Sumaco, Hollin-Loreto km 40 (SW0077), Tipaz et al. 378 (MO).

Guarea persistens is morphologically close to G. fissicalyx, which has a similar vegetative and floral structure. It differs in its hollow twigs (said to be inhabited by ants), in its laxly-branched inflorescence with long lateral branches, in the flowers borne on long slender pedicels, in the calyx which persists in the developing fruit and in the 4-locular ovary. The ecology of the species also differs, with Guarea persistens occurring in lower montane forest, while G. fissicalyx is confined to riverbanks and periodically flooded lowland forest. The ITS phylogeny confirms their close relationship near the top of the Amazonian clade. 
39. Guarea purusana C.DC., Bull. Herb. Boissier, Sér. 2, 6: 984 (1906); T.D.Penn. in T.D.Penn. et al., Fl. Neotrop. 28: 355, fig. 75 (1981). - Type: Brazil, Amazonas, Alto Purus, fr., Huber 4394 (lecto G, designated by Pennington in Pennington et al. (1981: 355); isolecto INPA, MG, RB). Fig. 49E.

For synonymy see T.D.Penn. in T.D.Penn. et al., Fl. Neotrop. 28: 355 (1981).

Abbreviated description. Young shoots and inflorescences coarsely pubescent with dark brown hairs, leaves with a terminal bud showing intermittent growth, leaflets 4 7 pairs, $18-34 \times 5-9.5 \mathrm{~cm}$, oblong or narrowly oblanceolate, chartaceous to thinly coriaceous, upper surface subglabrous, lower surface with indumentum on midrib and veins, secondary veins 17-24 pairs, usually straight and parallel, inflorescence axillary or in the axils of fallen leaves, 5-30 cm long, a slender densely-flowered panicle with short lateral branches to $2 \mathrm{~cm}$ long, petals 4-5, valvate, $9.5-10.5 \mathrm{~mm}$ long, appressed pubescent or sericeous outside, staminal tube 7.5-8 mm long, 2 $3 \mathrm{~mm}$ broad, anthers 8-11, ovary 5-8-locular, locules with (1-)2 superposed ovules, capsule $3.5-5.2 \times 2.2-3 \mathrm{~cm}$, obovoid to shortly botuliform, smooth or slightly constricted between the valves, minutely papillose, 5-8-valved, valves with 2 superposed seeds, pericarp 4-6 mm thick.

Distribution and ecology. Transamazonian from the mouth of the Amazon to southern Venezuela, Amazonian Brazil, Colombia, Ecuador, Peru and Bolivia. Apparently not present in the Guianas. In lowland rain forest, equally common on non-flooded land and in periodically flooded forest.

Representative additional collections. Colombia. Amazonas: Rio Caquetá, Isla Mariname (NW0172), Urrego 544 (NY).

Venezuela. Territorio Federal Amazonas: Dep. Atabapo, la base de Cuerpo Circular (NW0263), Marín 1764 (K, MO).

EcuAdor. Napo: Jatun Sacha Biological Station (SW0177), Palacios \& Freire 5150 (K).

Orellana: La Joya de los Sachas, Cantón Pompeya (SW0076), Gudiño \& Grefa 1818 (K).

Pastaza: Cantón Pastaza, Pozo Petrolero 'DANTA 2' (SW0176), Espinoza \& Coba 446 (K). Sucumbios: Lumbaqui (NW0077), Pennington et al. 12293 (K).

Peru. Amazonas: Dist. Imaza, Yamayakat (SW0578), Vásquez \& Vásquez 21031 (F). Huánuco: Prov. Puerto Inca, Llullapichis, DANTAS (SW0975), Palomares 9 (K). Loreto: Maynas, Rio Napo, Sucursari (SW0372), Gentry et al. 42681 (K).

Brazil. Acre: Fazenda Bom Sossego (SW0773), Campbell et al. 8836 (K). Amazonas: Municipio de Borba, BR 230 Transamazonica (SW0659), Henderson et al. 398 (K). Pará: Cuanta do Anajas (SW0049), Prance et al. 30291 (K).

Bolivia. Beni: Ballivian Prov., km 35 Yacumo - Rurrenabaque (SW1467), D.N. Smith et al. 14361 (K). Pando: 54 km SW of Cobija, Triunfo (SW1169), R.T. Pennington et al. 13 (K).

This species is both morphologically and phylogenetically close to Guarea grandifolia. It differs from Guarea grandifolia in the rather narrow oblong or oblanceolate leaves with numerous parallel secondary veins, and in the size and fine detail of the fruit. 
40. Guarea guidonia (L.) Sleumer, Taxon 5: 194 (1956); T.D.Penn. in T.D.Penn. et al., Fl. Neotrop. 28: 261 (1981). - Samyda guidonia L., Sp. Pl. ed. 1, 443 (1753). - Type: Illustration of Samyda foliis ovatis acuminatis in Plumier in Burman, P1. Amer. 139, t. 147, f. 2 (1757), designated by Pennington in Pennington et al. (1981: 265). Figs 33, 65A.

Guarea brachystachya DC., Prodr. 1: 624 (1824). - Lectotype (icon): Torner Collection plate no. 1478, chosen by McVaugh (2000).

For further synonymy see T.D.Penn. in T.D.Penn. et al., Fl. Neotrop. 28: 261-263 (1981).

Abbreviated description. Indumentum inconspicuous, puberulous to pubescent, leaves with indeterminate apical growth, leaflets up to $9(-14)$ pairs, $(6.5-) 10-16(-25)$ $\times(2.5-) 3-6(-9) \mathrm{cm}$, elliptic, oblong, lanceolate or oblanceolate, glabrous, secondary veins (6-)9-12(-17) pairs, inflorescence (4-)10-25(-45) cm long, a pyramidal thyrse, petals (3-)4-5, valvate, (5-)5.5-7.5(-9.5) mm long, staminal tube 3.5-7 $\mathrm{mm}$ long, (1-)1.5-2.5(-3) mm broad, anthers (7-)8(-11), ovary (3-)4(-5)-locular, locules 1ovulate, pubescent, capsule $1.5-2.5 \mathrm{~cm}$ long, globose to fig-shaped, 4-valved, usually with short stipe at base, pericarp smooth, not wrinkling on drying, shining, usually with conspicuous pale lenticels, glabrous, pericarp 1-2 mm thick, valves 1-seeded.

Distribution and ecology. Nicaragua, Costa Rica and Panama and throughout tropical America to Paraguay and northern Argentina, also in the Greater Antilles. In much of Amazonia it is a common tree of riverbanks and periodically flooded forest, but in the western Amazonian part of its range and in the Caribbean it is frequently found in non-flooded forest.

Representative additional collections. Costa RicA. Alajuela: San Carlos, Fortuna RB, Arenal Mundo Aventura (NW1084), Rodríguez 8481 (INB). Heredia: Sarapiquí, ZP la Selva (NW1084), Kriebel et al. 4019 (INB). Limón: Cantón Pococi, RNFS Barra del Colorado, Sardinas (NW1083), Araya 39 (INB). Puntarenas: Osa, Cuenca Terraba-Sierpe (NW0883), Gonzalez 3621 (INB).

Cuba. Camaguey: NE Sierra de Cubitas, Los Paredones (NW2177), Rico et al. 2022 (K).

Puerto Rico. Caribbean National Forest, El Verde Research Station (NW1865), Boom $10231(\mathrm{~K})$.

Venezuela. Anzoategui: Distrito Libertad, road from El Vigia to Buenos Aires (NW1064), Davidse \& Gonzalez 19481 (MO). Barinas: Distrito Pedraza, Curbati to El Algarrobo (NW0870), Dorr et al. 4695 (K). Bolívar: Municipio Sucre, Rio Caura, below Salto Aimara (NW0463), Elcoro 77 (K). Carabobo: $5 \mathrm{~km} \mathrm{~N}$ of Bejuma, Hacienda La Calceta (NW1068), Meier 3120 (K).

GuYana. Potaro-Siparuni region, 4-5 km N of Surama (NW0459), Hoffman et al. 1526 (K).

Surinam. Tumuc Humac Mts., Talouakem, upper Litani River (NW0254), AcevedoRodríguez et al. 5817 (K).

French Guiana. Inini (NW0353), Fleury 841 (K).

Ecuador. Morona-Santiago: Sucua (SW0278), Pabón et al. 296 (K). Napo: Jatun Sacha Biological Station (SW0177), Cerón \& Cerón 1300 (K). Orellana: Rio Napo, $5 \mathrm{~km}$ below Coca (SW0076), Neill et al. 6901 (K). Zamora-Chinchipe: $17 \mathrm{~km} \mathrm{NE}$ of Zamora (SW0478), Pennington \& Tenorio 10738 (K). 


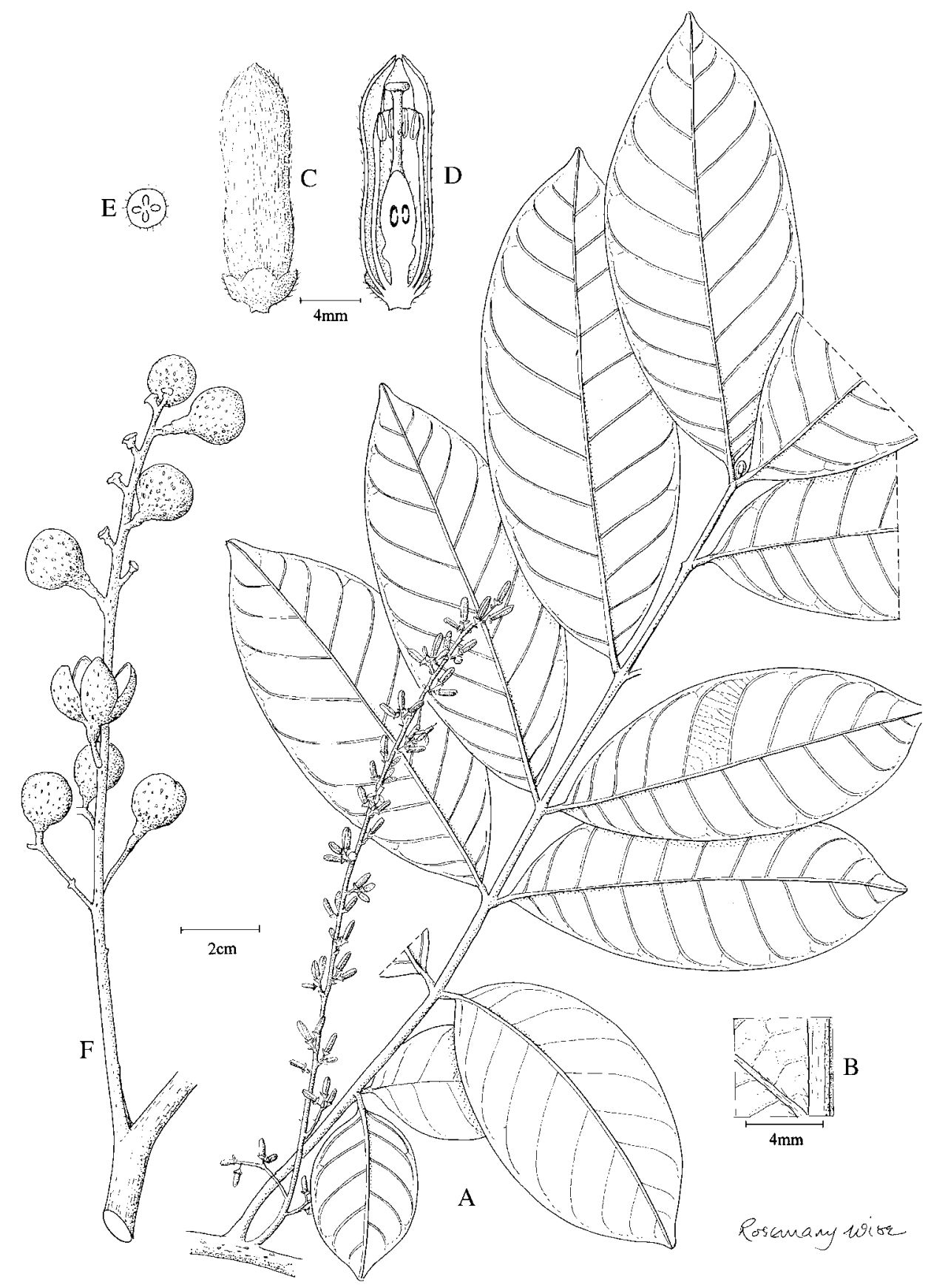

FIG. 33. Guarea guidonia (L.) Sleumer. A, habit; B, enlargement of leaf undersurface; C, flower; D, half-flower; E, cross-section of ovary; F, infructescence. (A-E, Hahn \& Tiwari 5213; F, Hoffman et al. 1526). 
Peru. Junín: San Ramón, Catarata del Tirol (SW1175), Daza et al. 16282 (K). Loreto: Requena, Yanallpa, R. Ucayali (SW0473), de Jong 177 (K).

BraziL. Acre: Municipio Tarauaca, Rio Muru, Seringal Vitoria Velha (SW0870), Figueiredo et al. 955 (K). Bahía: Municipio Jacobina, Chapada Diamantina (SW1140), Stannard et al. 2617 (K). Distrito Federal: APA de Cafuringa (SW1547), Pereira \& Alvarenga 2216 (K). Espirito Santo: Municipio Piuma, road to Itapemirím (SW2040), Pirani et al. 4745 (K). Goias: Municipio de Cabeceiras de Goias, km 15, on BR-020 (SW1547), Pereira \& Alvarenga 3052 (K). Mato Grosso: Serra das Araras, Vale de Currupira (SW1556), Dubs 2000 (K). Mato Grosso do Sul: Municipio Bodoquena, km 6 road to Bonito (SW2056), Pirani et al. 4851 (K). Minas Gerais: Caratinga (SW1942), Braga et al. 19526 (K). São Paulo: Municipio Teodoro Sampaio, Reserva Florestal Morro do Diablo (SW2252), Pastore \& Klein 59 (K).

Bolivia. La Paz: Prov. Nor Yungas, Alto Beni, Puerto Carmen, Seidel et al. 7570 (K). Santa Cruz: Prov. Ichilo, $1 \mathrm{~km} \mathrm{~S}$ of Carandá (SW1763), Saldias \& Lawrence 1435 (K).

Paraguay. Amambay: Cerro Lorito, Estáncia la Serrana (SW2255), Zardini \& Cardozo $45094(\mathrm{~K})$.

Guarea brachystachya DC. is based on an illustration made for Sesse \& Mocino's unpublished 'Flora Mexicana'. The original illustrations were loaned to de Candolle at Montpelier in France, where he was preparing the Prodromus, and he arranged for rough tracings to be made of them before returning the originals to Barcelona in 1820. The drawings were then lost for 150 years. The tracings made by de Candolle, known as the 'Calques des dessins', were often the sole basis of some species in the Prodromus, including no. 155 which is Guarea brachystachya. This was chosen as the lectotype of the species in Flora Neotropica (Pennington et al., 1981). However, the original drawings were rediscovered in Spain in 1979, and they were acquired by the Hunt Institute for Botanical Documentation Library, where they are now known as the Torner Collection.

McVaugh (2000) pointed out that a better choice, as lectotype, would have been plate no. 1478 in the Torner Collection, from which DC. Plate 155 was copied. Torner 1478, which we have now had an opportunity to study, is annotated 'Guarea brachystachya' by A. P. de Candolle. On the basis of DC. Plate 155 this species was placed in the synonymy of Guarea glabra by Pennington in Pennington et al. (1981), but after examining the much more detailed Torner 1478, we consider that it should be in the synonymy of G. guidonia. The stout, many-flowered inflorescence and lenticellate twigs and fruit all point to Guarea guidonia. It is not known for certain whether the drawing was made in Cuba or Puerto Rico, but Guarea glabra is absent from Cuba, and in Puerto Rico is characterised by a very short, few-flowered inflorescence, and the fruits and twigs are not lenticellate.

41. Guarea fissicalyx Harms, Notizbl. Bot. Gart. Berlin-Dahlem 11: 383 (1932); Palacios, Fl. Ecuador 82, Fam. 98, Meliaceae: 24 (2007). - Type: Peru, Loreto, Florída [SW0174], fl., Klug 2090 (holo B, destroyed; lecto K, designated here; isolecto F, GH, MO, NY, S). Figs 34, 54E.

Guarea gomma auct. non Pulle: T.D.Penn. in T.D.Penn. et al., Fl. Neotrop. 28: 291 (1981), p.p. 


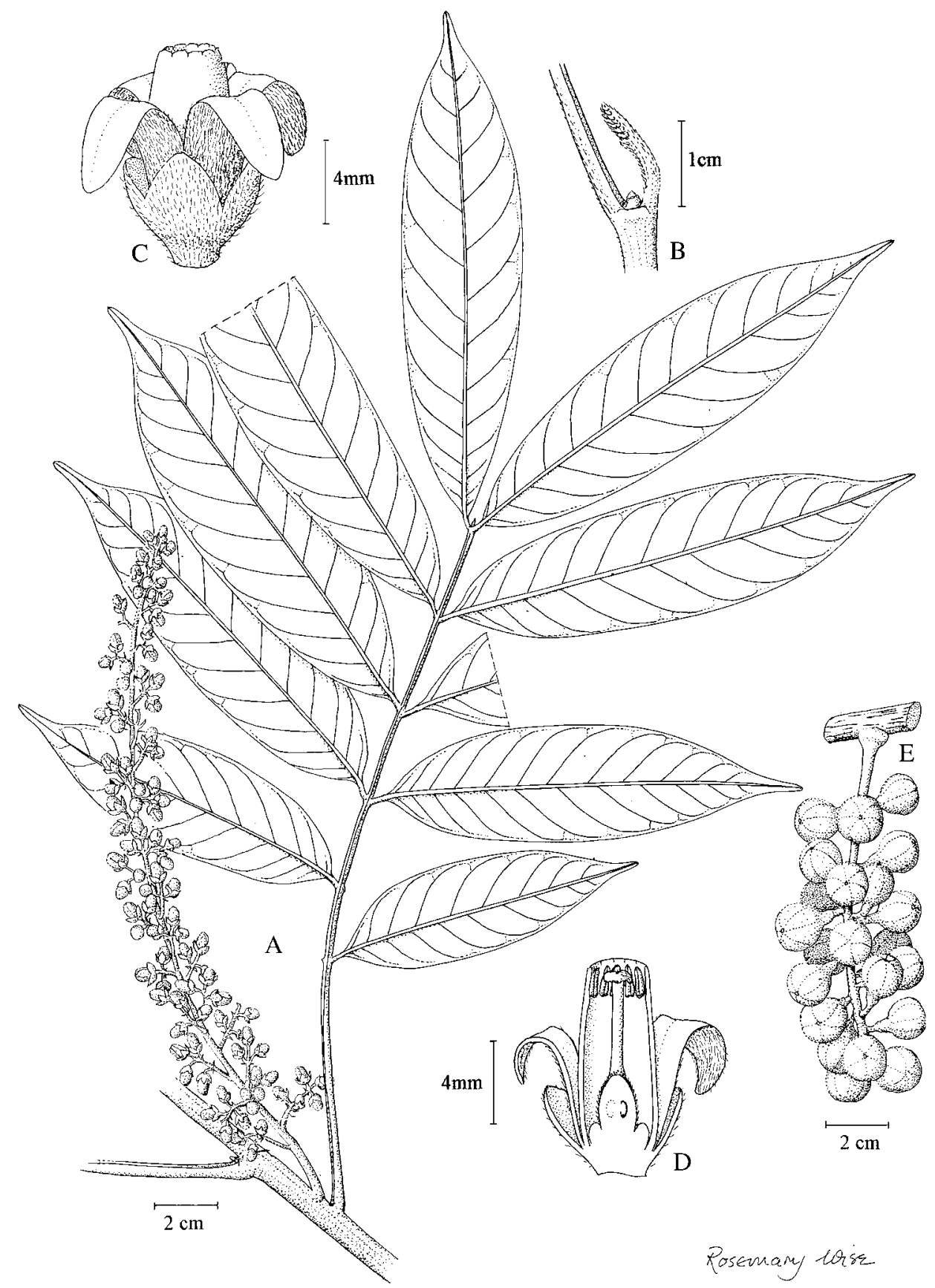

FIg. 34. Guarea fissicalyx Harms. A, habit; B, shoot apex; C, flower; D, half-flower; E, infructescence. (A, B, Schultes 46-303; C, D, Vásquez \& Jaramillo 6333; E, Zarucchi \& Balick 1768). 
Young shoots 5-8 $\mathrm{mm}$ diam., usually solid, minutely appressed puberulous, soon glabrous, pale greyish-brown, smooth, without lenticels. Leaves pinnate with a caducous terminal bud, without intermittent growth, petiole $6.5-13 \mathrm{~cm}$ long, semiterete to terete at the apex, finely appressed puberulous to glabrous, rhachis $16-40 \mathrm{~cm}$ long, semiterete, subglabrous; petiolule 2-8 mm long, glabrous. Leaflets opposite, 4-8 pairs, $12-22 \times 3-6 \mathrm{~cm}$, usually elliptic, elliptic-lanceolate or oblanceolate, occasionally oblong, apex narrowly attenuate or acuminate, base usually obtuse or rounded, occasionally narrowly cuneate, thinly coriaceous, glabrous or with sparse pubescence on lower midrib, not glandular-punctate or -striate; venation eucamptodromous, midrib sunken on the upper surface, secondaries 10-12(-14) pairs, ascending, straight or slightly arcuate, slightly convergent, intersecondaries absent, tertiaries oblique. Inflorescence axillary or on twigs below the leaves, 10-40 cm long, a slender manyflowered thyrse with lateral branches $1-3 \mathrm{~cm}$ long, puberulous; pedicel c. $1 \mathrm{~mm}$ long (above the articulation). Calyx closed in bud, 3-4 mm long, cup-shaped, deeply and irregularly 3-4-lobed to halfway or more, sometimes to near the base, the lobes obtuse to rounded, sparsely puberulous on both surfaces. Petals 5-6, valvate, 7-8 $\mathrm{mm}$ long, 1.5-3 mm broad, strap-shaped, apex acute, densely appressed puberulous outside with pale yellowish hairs, glabrous inside. Staminal tube c. $6 \mathrm{~mm}$ long, 2-3 mm broad, margin undulate, glabrous; anthers 9-11, c.1 mm long, oblong, glabrous. Nectary a broad stipe c. $1 \mathrm{~mm}$ long surmounted by a narrow collar, glabrous. Ovary pubescent, 5-6-locular, locules with 1 ovule, style stout, c. $4 \mathrm{~mm}$ long, with a broad discoid stylehead. Capsule 1.5-2.2 cm long, broadly pyriform, apex truncate, sometimes tapering to a short stipe at the base, 4-6-valved, smooth, glabrous, pericarp 0.5-1 mm thick, valves 1-seeded. Seeds c. $1 \mathrm{~cm}$ long, shaped like the segments of an orange, thin-walled.

Field characters. Tree to $25 \mathrm{~m}$ high and $50 \mathrm{~cm}$ diam., flowers with reddish calyx and cream-coloured corolla; the calyx is completely closed in bud and splits irregularly. Flowering is recorded from March to May and in November, fruiting in April.

Distribution and ecology. Amazonian Colombia, Ecuador and Peru, usually along riversides and in periodically flooded forest.

Collections examined. Colombia. Amazonas: Rio Loretoyacu (SW0370), Black \& Schultes 46-303 (K). Vaupés: Mitú (NW0170), Zarucchi \& Balick 1768 (K).

ECuADOR. Sucumbios: Cuyabeno Reserve, from outlet of Laguna Grande and $5 \mathrm{~km}$ upstream (NW0076), Balslev et al. 84780 (MO); Cantón Lago Agrio, Cuyabeno Reserve, banks of R. Aguarico (SW0075), Palacios et al. 9466 (K, MO, NY, QCNE); Cuyabeno Reserve, Zancudo (SW0075), Palacios et al. 8161 (QCNE).

Peru. Loreto: Centro de Investigaciones de Jenaro Herrera (SW0473), Collector unknown, tree no. 7-3/8 (K, MOL); Jenaro Herrera, Supay Cocha, Quebrada Braga (SW0473), Daly et al. $5770(\mathrm{~K})$; Freitas 78 (K); Maynas, Sargento Lores, below Tamishiyacu (SW0472), McDaniel \& Rimachi 23667 (K); Requena, Jenaro Herrera, Bosque Ribereño 'Braga' (SW0473), Valcarcel 525 (K); Maynas, Progreso (Isla Iquitos) (SW0373), Vásquez \& Jaramillo 6274 (K); Maynas, Yanamono, Campamento Explorama Lodge (SW0372), Vásquez \& Jaramillo 6329 (K), 6333 (K); Requena, Sapuena, Jenaro Herrera (SW0473), Vásquez \& Jaramillo 10108 (K, NY). 
This species was treated by Pennington in Pennington et al. (1981) as a doubtful synonym of Guarea gomma, but was recently reinstated by Palacios (2007). Additional, complete material has clarified and confirmed the differences between the species, which although they are slight and break down individually, in combination provide a discontinuity. They are enumerated below.

Guarea gomma: leaflets oblong, secondary veins $12-18$ pairs, calyx shallowly to deeply regularly divided, petals $8-12 \mathrm{~mm}$ long, fruit $2.5-4 \mathrm{~cm}$ long.

Guarea fissicalyx: leaflets usually elliptic, secondary veins 10-12(-14) pairs, calyx deeply and irregularly divided, petals $7-8 \mathrm{~mm}$ long, fruit $1.5-2.2 \mathrm{~cm}$ long.

Guarea fissicalyx is nearly always recorded from riversides or periodically flooded forest, whereas G. gomma occurs in non-flooded forest.

42. Guarea grandifolia DC., Prodr. 1: 624 (1824); T.D.Penn. in T.D.Penn. et al., Fl. Neotrop. 28: 336 (1981). - Type: French Guiana specimen annotated 'Cayenne ou Guyane-francoise, Museum de Paris 1821', fl., Collector unknown s.n. (holo G-DC). Figs 35, 65B.

For synonymy see T.D.Penn. in T.D.Penn. et al., Fl. Neotrop. 28: 336 (1981).

Abbreviated description. Indumentum of young shoots and inflorescence variable, from puberulous to tomentose, leaves with a terminal bud showing intermittent growth, leaflets up to $10(-22)$ pairs, $13.5-37(-63) \times(3.4-4.5-13(-20) \mathrm{cm}$, oblong or elliptic, less frequently oblanceolate, chartaceous to coriaceous, glabrous above, veins puberulous to tomentose below, lamina sparsely puberulous or pubescent, or glabrous, inflorescence axillary or ramiflorous, rarely cauliflorous, 10-40(-50) cm long, a pyramidal thyrse, petals 4-5(-7), valvate, (9-)10-14(-17) $\mathrm{mm}$ long, staminal tube (7-)9-11(-14) mm long, (2-)3-5 mm broad, anthers (8-)10-12(-13), ovary (4-)78(-10)-locular, locules with 2 superposed ovules, capsule $3.5-6(-8) \mathrm{cm}$ long, $3-$ $4(-7) \mathrm{cm}$ broad, globose, ellipsoid, pyriform or obovoid, often tapering for $2 / 3$ of its length to a short stout stipe, smooth or faintly longitudinally lined, densely puberulous or papillose, 5-8-valved, valves with 2 superposed seeds, pericarp 5-6(-15) mm thick.

Distribution and ecology. Southeastern Mexico, throughout Central America and northern and western South America. A tree of non-flooded lowland rain forest, in Central America often recorded from riverbanks.

Representative additional collections. Mexico. Chiapas: Huehuetán, Belisario Dominguez (NW1592), Ventura \& Lopez 220 (NY). Veracruz: San Andres Tuxtla, Los Tuxtlas Biological Station (NW1895), Ibarra \& Sinaca 1966 (MEXU, NY).

Guatemala. Izabal: Santo Tomas de Castilla (NW1588), Marshall et al. 386 (K).

Belize. Toledo: Southern Maya Mountains, Bladen Nature Reserve (NW1688), Davidse \& Holland 36491 (K).

Honduras. Atlántida: N slope of Pico Bonito, Campamento Quebrada Grande (NW1586), Liesner \& Mexia 26038 (K). Gracias a Díos: R. Mocorón (NW1584), Nelson \& Vargas 5087 (K). Yoro: E of San José Texiguat (NW1587), Brant \& Hazlett 2881 (K). 


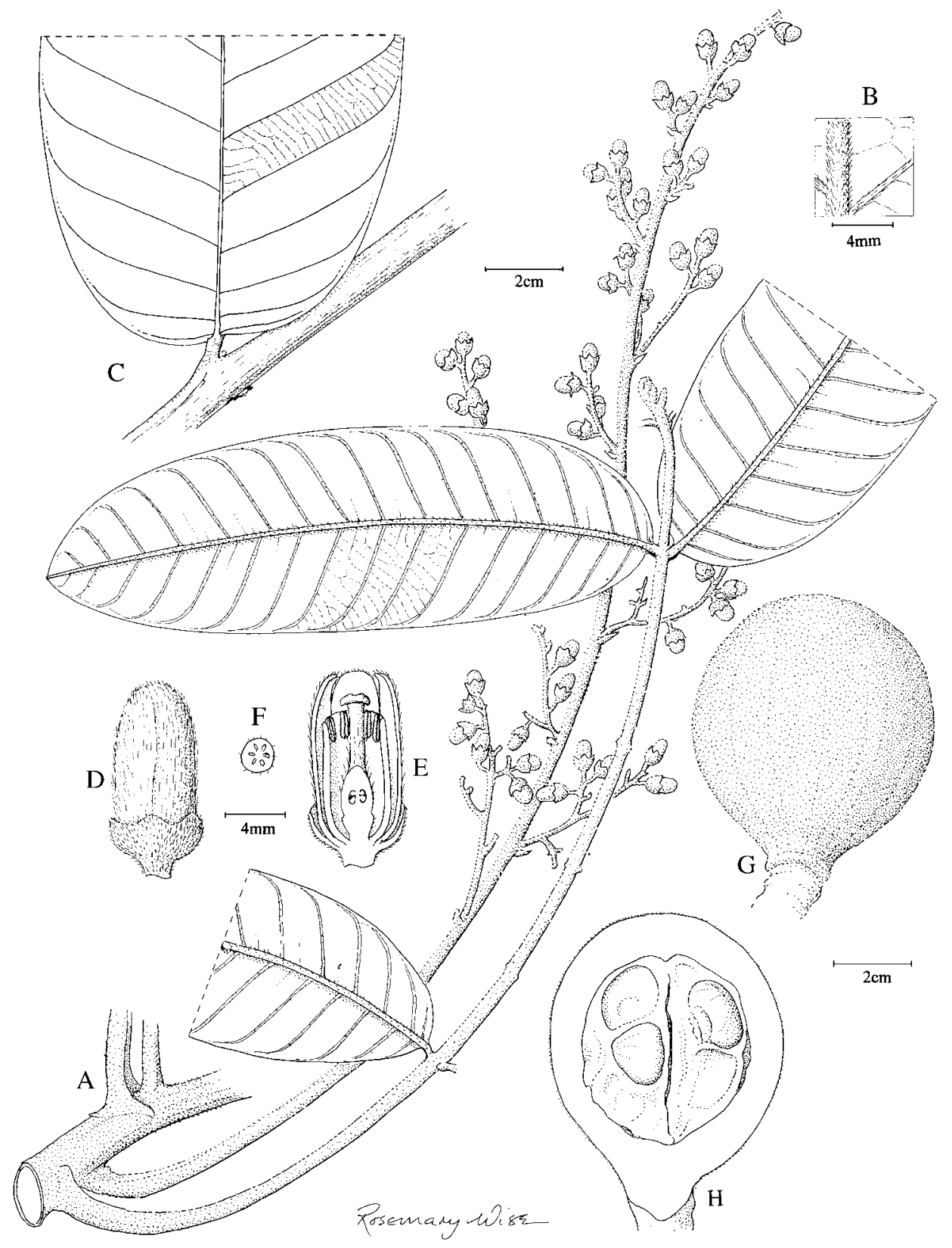

FIG. 35. Guarea grandifolia DC. A, habit; B, enlargement of leaf undersurface; C, base of mature leaflet; D, flower bud; E, half-flower; F, cross-section of ovary; G, fruit; H, longitudinal section of fruit. (A, B, Lanjouw 836; C-F, Mori et al. 22645; G, H, Mori et al. 15685). 
Nicaragua. Boaco: Cerro Mombachito (NW1285), Stevens \& Hahn 18932 (K). Chontales: between Rio Rizcocho \& Rio El Jordan (NW1285), Stevens \& Montiel 21471 (K). Zelaya: Neptune Mining Co. (NW1484), Pipoly 3515 (NY).

Costa Rica. Alajuela: Monteverde Reserve, Río Peñas Blancas (NW1084), Bello 606 (K). Heredia: Puerto Viejo de Sarapiqui (NW1084), Hammel \& Grayum 17333 (K). Puntarenas: Corcovado National Park, Skyway trail (NW0883), Kernan \& Phillips 687 (K). San José: Cantón Puriscal, Cuenca del Pirris-Damas (NW0984), Jimenez \& Acosta 2261 (INB).

Panama. Darien: western slope of Serrania de Pirre, below Cana mine (NW0777), McPherson 12270 (MO). San Blas: Cangandi (NW0979), Nevers \& Herrera 7096 (K).

Colombia. Amazonas: Araraquara, R. Caquetá (SW0072), Alvarez et al. 670 (K). Antioquia: Municipio Mutata, Sabaletas (NW0776), Callejas et al. 9765 (K).

Venezuela. Amazonas: Rio Metacuni, Frente No. 4, Stergios \& Velazco 14223 (K).

Guyana. Upper Essequibo Region, Rewa River, Corona Falls (NW0358), Jansen-Jacobs et al. $5782(\mathrm{~K}, \mathrm{NY}, \mathrm{U})$.

Surinam. Kabelebo Dam area, Nickerie Dist. (NW0457), Lindeman \& de Roon 890 (K).

French Guiana. Montagne Bellevue de l'Inini (NW0353), de Granville et al. 7628 (K, NY).

ECUADOR. Orellana: Orellana, Huaorani Reserve, Miwaguino (SW0076), Freire \& Naranjo 681 (K). Sucumbios: Shushufindi, El Pilchi (SW0076), Freire \& Chavez 5420 (K). ZamoraChinchipe: Nangaritza, Cordillera del Condor, R. Numpatakaime (SW0478), Quizhpe et al. $500(\mathrm{~K})$.

Peru. Amazonas: Bagua Province, Dist. Imaza, Yamayakat (SW0478), Jaramillo et al. 167 (K). Loreto: Yanomono Explorama Tourist Camp, Rio Amazonas (SW0372), Gentry et al. $36565(\mathrm{~K})$.

Brazil. Acre: Fazenda Bom Sossego, between Igarapé do Cujubim \& Jacamín (SW0773), Campbell et al. 9034 (K). Amazonas: Municipio São Paulo de Olivença, 8 km S (SW0368), Daly et al. 4489 (K). Roraima: Yanomami Indigenous area, near Xitei mission (NW0263), Milliken $2336(\mathrm{~K})$.

43. Guarea aguilarii Al.Rodr., Lankesteriana 6: 103 (2006). - Type: Costa Rica, Puntarenas, Parque Nacional Corcovado, Llorona to Los Planes [NW0883], Kernan \& Phillips 1020 (holo INB). Fig. 60A.

Young shoots stout, $1-1.5 \mathrm{~cm}$ diam., minutely appressed puberulous at first, becoming glabrous, smooth, brown, with some long pale lenticels. Leaves pinnate with an active terminal bud, petiole $9.5-12.5 \mathrm{~cm}$ long, semiterete, subglabrous, rhachis up to $40 \mathrm{~cm}$ long, semiterete to slightly channelled, subglabrous; petiolule swollen, $0.5-1 \mathrm{~cm}$ long. Leaflets opposite, up to 4 pairs, $25-40 \times 10-15 \mathrm{~cm}$, broadly elliptic to oblong-elliptic, apex acuminate, base acute to narrowly cuneate, chartaceous, glabrous; venation eucamptodromous, midrib sunken on the upper surface, secondaries 14-15 pairs, ascending, straight, parallel, intersecondaries absent, tertiaries oblique. Inflorescence ramiflorous or cauliflorous, a small panicle up to $8 \mathrm{~cm}$ long, lateral branches to $3 \mathrm{~cm}$ long, pedicel 1-2 $\mathrm{mm}$ long above the articulation. Calyx 5-6 mm long, margin shallowly lobed, minutely puberulous. Petals 5-6, 15-16 mm long, 1.5-2 $\mathrm{mm}$ broad, apex acute, sericeous outside, glabrous inside. Staminal tube 11-12 mm long, c. $4 \mathrm{~mm}$ broad, margin shallowly toothed, glabrous; anthers 12, 2-2.5 mm long. Nectary 2-2.5 mm long, expanded below the ovary. Ovary 6-9-locular, locules with 2 superposed ovules, sericeous, style glabrous, style-head discoid. Fruit 3-5 cm long, depressed-globose and 
slightly broader than long, depressed at the apex, base truncate, 6-9-valved, strongly constricted between the valves when dry, glabrous with pale lenticels.

Field characters. Tree to $30 \mathrm{~m}$ high and $25 \mathrm{~cm}$ diam., flowers cream-coloured, fruit maturing orange to red, the seed covered by an orange arillode. Flowering recorded in September, fruiting in March, April and September.

Distribution and ecology. Pacific slopes of Costa Rica (Puntarenas and San José), in wet forest up to $700 \mathrm{~m}$ altitude.

Collections examined. Costa Rica. Puntarenas: Osa, Osa Peninsula, Aguabuena (NW0883), Aguilar 476 (INB); Osa, near Rincón, Rancho Quemado (NW0883), Gentry et al. 78671 (INB); Fila Estero Guerra, Sierpe (NW0883), Marin 217 (INB). San José: Tarrazu, San Lorenzo, E of R. Naranjo (NW1084), Sanchez et al. 748 (CR).

This plant is morphologically very close to Guarea grandifolia except that the capsule is unusually constricted between the valves. All other characters of leaves and flowers fall easily within the variation of Guarea grandifolia.

44. Guarea cartaguenya Cuatrec., Fieldiana, Bot. 27(1): 70 (1950); T.D.Penn. in T.D.Penn. et al., Fl. Neotrop. 28: 345, fig. 75 (1981). - Type: Colombia, Dept. del Valle, Cordillera Occidental, Hoya del Rio Anchicaya, fr., Cuatrecasas 15218 (holo F; iso COL). Fig. 55A.

Abbreviated description. Young shoots and inflorescences puberulous, leaves with a terminal bud showing intermittent growth, leaflets up to 8 pairs, $22.5-40 \times 7.5-$ $14.5 \mathrm{~cm}$, oblong, elliptic or oblanceolate, glabrous above, crisped puberulous below with pale hairs, eventually becoming glabrous, coriaceous, inflorescence axillary, 35-50 cm long, a broad and laxly-branched pyramidal panicle, lower branches up to $26 \mathrm{~cm}$ long, petals 4-5, 15-17.5 mm long, appressed puberulous to finely sericeous outside, staminal tube 12-13 mm long, 4-5 mm broad, anthers (9-)10-12, ovary 4-6(-7)-locular, locules with 2 superposed ovules, capsule 6-9 $\mathrm{cm}$ long, 5-7 $\mathrm{cm}$ broad, obovoid to pyriform, faintly longitudinally ribbed when dry, otherwise smooth, finely puberulous or papillose, 5-6-valved, pericarp 5-10 mm thick, valves with 2 superposed seeds.

Distribution and ecology. Pacific drainage of Colombia and Ecuador, where it is a species of lowland and montane rain forest from sea level to $1700 \mathrm{~m}$ altitude.

Additional collections examined. Colombia. Antioquia: Murri la Blanquita, Rio Murri (NW0676), Gentry et al. 75897 (K). Valle: Rio Anchicaya near CVC hydroelectric plant (NW0376), Gentry 35691 (K).

EcuAdor. Carchi: Tulcan Cantón, Awa Reserve (NW0178), Quelal et al. 625 (NY); Gualpi Alto (NW0078), Thomson 58856 (K); Cantón Tulcán, Tobar Donoso, Sector Sabalera (NW0178), Tipaz et al. 1296 (K); Lita (NW0078), van der Werff et al. 9571 (K, NY). Esmeraldas: San Lorenzo Canton, Awa Reserve, Centro Guadualito (NW0178), C. Aulestia et al. 305 (NY); Parroquia Mataje, Awa Reserve (NW0178), C. Aulestia et al. 583 (MO). Imbabura: valley of R. Mira (NW0078), Pennington \& Cruz 10527 (K). Pichincha: Quito Cantón, Nanegal, Maquipucuna Reserva (NW0078), Tipaz \& Quelal 181 (F, K). 
45. Guarea casimiriana Harms in Engler \& Prantl., Nat. Pflanzenfam., ed. 2, 19b1: 133, 177 (1940); T.D.Penn. in T.D.Penn. et al., Fl. Neotrop. 28: 333, fig. 70 (1981). - Type: Peru, Loreto, Yurimaguas, fl., Poeppig 2261 (holo W; iso F, NY, OXF). Fig. 55B.

For synonymy see T.D.Penn. in T.D.Penn. et al., Fl. Neotrop. 28 : 333 (1981).

Abbreviated description. Young shoots and inflorescences densely hispid with erect yellow stiff hairs, leaflets $32-39 \times 9-10.5 \mathrm{~cm}$, narrowly oblong or oblanceolate, chartaceous, with hispid indumentum on the lower surface, especially along the veins, venation brochidodromous, secondary veins 38-40 pairs, straight, parallel, inflorescence cauliflorous, a laxly-flowered spike to $13 \mathrm{~cm}$ long, petals c. $16 \mathrm{~mm}$ long, densely golden strigose outside, staminal tube 12-13 mm long, 2-3 mm broad, anthers 9-10, ovary 6-locular, locules with 2 superposed ovules, fruit unknown.

Distribution and ecology. Known only from the type collection in Amazonian Peru, where it is a component of the understorey in lowland rain forest.

46. Guarea constricta Al.Rodr., Lankesteriana 6: 106 (2006). - Type: Costa Rica, San José, Perez Zeledon, Savegre Abajo de Rio Nuevo, finca de Victor Julio Mena [NW0983], fl., A. Estrada 2016 (holo CR; iso INB, MO). Figs 36, 60B.

Young shoots stout, 1.2-1.5 cm diam., hollow, subglabrous, smooth, greyish brown, with sparse pale lenticels. Leaves pinnate with an inactive terminal bud, petiole $15-20 \mathrm{~cm}$ long, semiterete, glabrous, rhachis $27.5-33 \mathrm{~cm}$ long, terete or slightly channelled on the upper surface, glabrous; petiolule stout, $0.9-1.2 \mathrm{~cm}$ long. Leaflets opposite, 4 pairs, $30-50 \times 10-18 \mathrm{~cm}$, broadly elliptic, apex shortly acuminate, base acute to narrowly attenuate, glabrous, chartaceous, drying pale green; venation eucamptodromous, midrib not raised or sunken on the upper surface, secondaries 11-14 pairs, ascending, slightly arcuate and convergent, intersecondaries absent, tertiaries oblique. Inflorescence on branches below the leaves, 5-25 cm long, a panicle, the lowest lateral branches to $5 \mathrm{~cm}$ long, glabrous; pedicel 2-3 mm long (above the articulation). Calyx shallowly cupshaped, 2-3 mm long, with shallow irregular obtuse lobes, glabrous. Petals $4,12-14 \times$ $2 \mathrm{~mm}$, strap-shaped, apex acute, glabrous. Staminal tube 10-12 $\times 3 \mathrm{~mm}$, flask-shaped, margin entire, glabrous; anthers 8, c.1 mm long, glabrous, dehiscent. Nectary a stout stipe expanded below the ovary, c. $2 \mathrm{~mm}$ long, glabrous. Ovary c. $3 \mathrm{~mm}$ long, ovoid, 4-locular, loculi with 2 superposed ovules, glabrous. Capsule $4.5-6 \times 2.5-5 \mathrm{~cm}$, broadly oblong, apex obtuse, not or scarcely constricted between the seeds, sometimes contracted at the base into a stout stipe $\mathrm{c} .1 .8 \mathrm{~cm}$ long and $1 \mathrm{~cm}$ broad, 4-valved, valves with 2 superposed seeds, pericarp dark brown, rough or smooth, densely lenticellate, glabrous. Seeds c. $3 \times 1 \mathrm{~cm}$; embryo with superposed cotyledons.

Field characters. Treelet or tree to $20 \mathrm{~m}$ high, inner bark pinkish. Flowers with white petals and yellow stamens, calyx green with red apices to the lobes. Flowering recorded in February, mature fruit in April. 


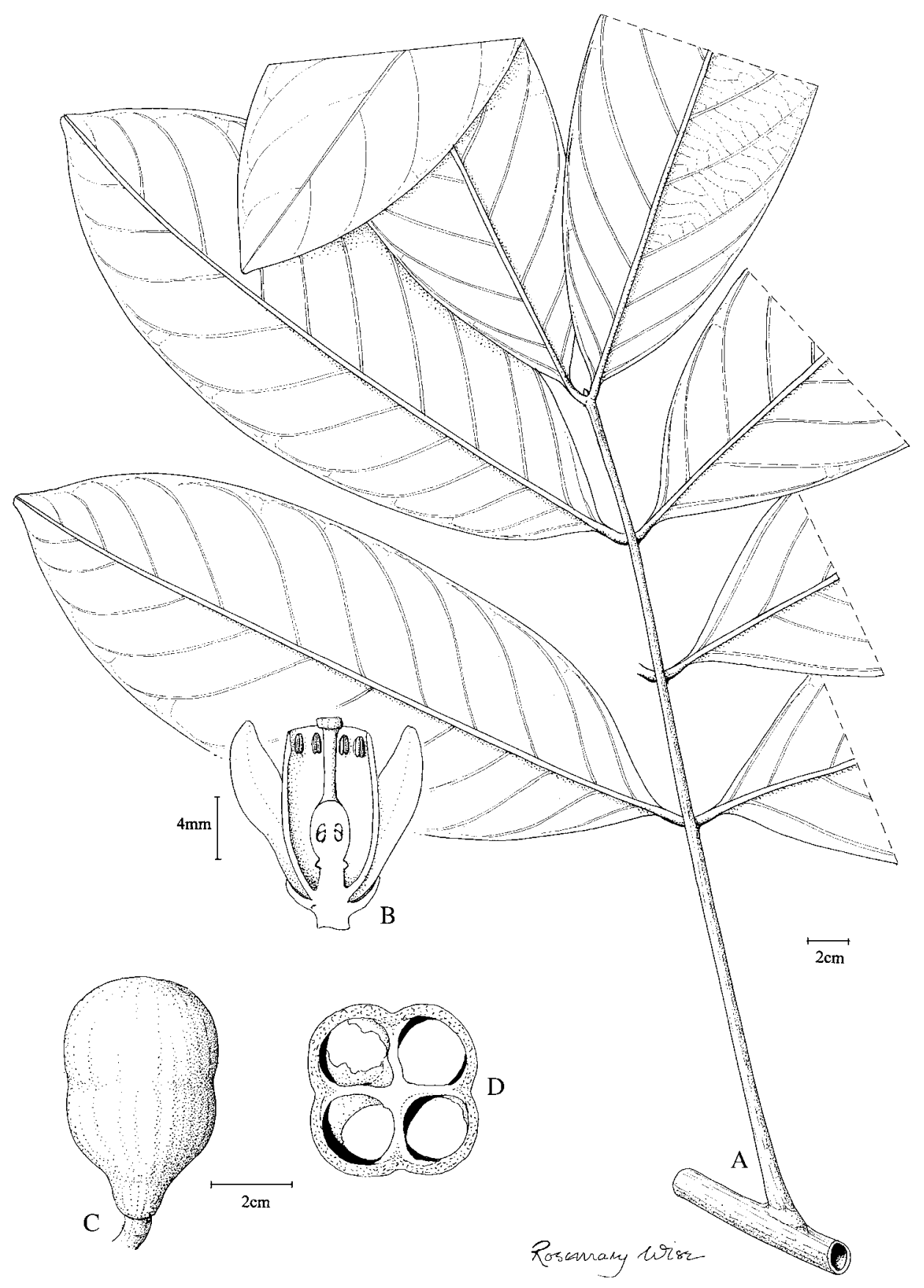

FIG. 36. Guarea constricta Al.Rodr. A, leaf; B, half-flower; C, fruit; D, cross-section of fruit. (A-D, Hammel \& Robles 16760). 
Distribution and ecology. In rain forest on the Pacific drainage of Costa Rica, from sea level to $1240 \mathrm{~m}$ altitude.

Collections examined. Costa Rica. Puntarenas: Peninsula de Osa, Reserva Forestal Golfo Dulce, 10 km SW of La Palma (NW0883), Hammel \& Robles 16760 (INB, MO); Golfito, R.N. Esquinas, Ridge Costeña/Cruces (NW0883), Huber \& Weissenhofer 1566 (CR). San José: Cantón Perez Zeledon, Cuenca del Baru, Tinamaste (NW0983), Rodríguez et al. 139 (INB); Tarrazu, San Lorenzo, Quebrada Saletrillo (NW0984), Rodríguez 9617 (INB).

This species is similar to Guarea bijuga, differing only in the larger flowers with biovulate ovary locules and larger fruit. It may be distinguished by the hollow twigs, large leaflets which dry pale green, whole plant glabrous, petals $12-14 \mathrm{~mm}$ long, and large 4-valved fruit with 2 superposed seeds in each valve.

47. Guarea convergens T.D.Penn. in T.D.Penn. et al., Fl. Neotrop. 28: 260, fig. 53 (1981). - Type: Brazil, Amazonas, Manaus to Caracarai road, km 154, fl., Pennington, Prance, Ramos \& Monteiro 9967 (holo INPA; iso FHO, MO, NY). Fig. 49F.

Abbreviated description. Indumentum inconspicuous, appressed puberulous or shortly pubescent, leaves with indeterminate apical growth, leaflets 3-12 pairs, 11.5-18.5 $\times$ 4-6 cm, elliptic oblong or oblanceolate, secondary veins 7-11 pairs, arcuate and convergent, inflorescence 5-17 cm long, a slender or pyramidal thyrse, petals 4, valvate, $6-7.5 \mathrm{~mm}$ long, staminal tube $5-5.5 \mathrm{~mm}$ long, $1.5-3 \mathrm{~mm}$ broad, anthers $7-8$, ovary (3-)4-locular, locules 1-ovulate, capsule $2.5-4.5 \mathrm{~cm}$ long, 4-valved, \pm globose, valves obscurely 6-7-ribbed and verruculose, minutely puberulous, pericarp 3-5 $\mathrm{mm}$ thick, without lenticels, valves 1-seeded.

Distribution and ecology. Southern Venezuela, French Guiana, central and western Brazilian Amazonia and Amazonian Peru, in lowland rain forest on non-flooded land.

Additional specimens examined. Venezuela. Territorio Federal Amazonas: San Carlos de Rio Negro, $20 \mathrm{~km} \mathrm{~S}$ of confluence of Rio Negro and Brazo Casiquiare (NW0167), Clark \& Maquirino 7641 (K), 8354 (US).

French Guiana. Bassin du Sinnamary, Crique Plomb (NW0553), Loubry 1774 (K).

Peru. Loreto: Centro de Investigaciones de Jenaro Herrera (SW0473), Collector unknown, Tree no.1-2/90 (K).

Brazil. Acre: Reserva INCRA Santa Luzia, km 40, BR-364 (SW0772), Campbell et al. 7077 (K). Amazonas: Reserva Florestal Ducke (SW0259), Costa \& Assunção 384 (K), Nascimento et al. 590 (K), Ribeiro et al. 1698 (K).

48. Guarea corrugata Cuatrec., Fieldiana, Bot. 27: 72 (1950); T.D.Penn. in T.D.Penn. et al., Fl. Neotrop. 28: 343, fig. 75 (1981). - Type: Colombia, Dept. de Valle, Cordillera Occidental, Hoya del Rio Albán, fl., fr., Cuatrecasas 22337 (holo F; iso COL). Fig. 55C.

Abbreviated description. Young shoots and inflorescences minutely appressed puberulous, leaves with a terminal bud showing intermittent growth, leaflets up to 
8 pairs, $18-25 \times 5-11 \mathrm{~cm}$, oblong-elliptic to elliptic, coriaceous, lower surface minutely sericeous at first, soon glabrous, secondary veins $12-16$ pairs, inflorescence ramiflorous, up to $13 \mathrm{~cm}$ long, a slender panicle, petals 4 , valvate, c. $8 \mathrm{~mm}$ long (bud), sericeous outside, staminal tube c. $6 \mathrm{~mm}$ long, c. $3 \mathrm{~mm}$ broad, anthers $8-9$, ovary 4-locular, locules with 2 superposed ovules, capsule c. $5.5 \mathrm{~cm}$ long, c. $3.5 \mathrm{~cm}$ broad, pyriform with c. 16 longitudinal ridges each of which is conspicuously corrugate, minutely appressed puberulous, 4-valved, pericarp 6-7 $\mathrm{mm}$ thick, valves with 2 superposed seeds.

Distribution and ecology. Still known only from the type collection in western Colombia.

49. Guarea corticosa Al.Rodr., Lankesteriana 6: 107 (2006). - Type: Costa Rica, Puntarenas, Reserva Forestal Golfo Dulce, Rincón de Osa, Quebrada Banegas [NW0883], fr., Aguilar 488 (holo INB; iso MO). Figs 37, 60C.

Young shoots $8-10 \mathrm{~mm}$ diam., minutely appressed puberulous at first, soon glabrous, smooth, brown, becoming slightly suberous. Leaves pinnate with a terminal bud with intermittent growth, petiole $6-11.5 \mathrm{~mm}$ long, channelled above, glabrous, rhachis to $46 \mathrm{~cm}$ long, semiterete or terete, glabrous; petiolule swollen, 3-6 mm long. Leaflets opposite, up to 7 pairs, $26-38 \times 13.5-19 \mathrm{~cm}$, broadly elliptic, apex acuminate, base acute to obtuse or rounded, and often asymmetric on the lower leaflets, chartaceous, drying pale green, glabrous; venation eucamptodromous, midrib slightly sunken on the upper surface, secondaries 12-13 pairs, ascending, slightly arcuate, \pm parallel, intersecondaries short or absent, tertiaries oblique. Inflorescence on larger twigs and trunk, a slender panicle c. $2 \mathrm{~cm}$ long, flowers (not seen by me) subsessile. Calyx 3-4.5 mm long, with 3-4 shallow lobes, minutely appressed puberulous outside. Petals 4, 11-12.5 $\mathrm{mm}$ long, c. $2 \mathrm{~mm}$ broad, apex acute, sericeous outside. Staminal tube 7-10.5 $\mathrm{mm}$ long, 3-3.5 mm broad, margin crenulate, glabrous; anthers 8, 1.75-2 mm long. Nectary a stipe 1-1.5 mm long. Ovary sericeous, 4-6(-8)-locular, locules with 2 superposed ovules, style $2.5-3 \mathrm{~mm}$ long, style-head discoid. Capsule 2-3 $\times 2.5 \mathrm{~cm}$, globose to pyriform, truncate at apex and base, 6-valved, the valves irregularly ribbed and tuberculate, valves with 2 superposed seeds. Seeds c. $1 \mathrm{~cm}$ long.

Field characters. Treelet to $6 \mathrm{~m}$ high with corky bark, flowers cream-coloured. Flowering recorded in May, fruiting in September and February.

Distribution and ecology. Known only from wet forest on the Pacific slopes of Costa Rica, up to $500 \mathrm{~m}$ altitude.

Collections examined. Costa Rica. Puntarenas: Golfo Dulce, entrada a Chocuaco, Rincón (NW0883), Aguilar 312 (INB); PN Corcovado, Los Planes (NW0883), Cordero 253 (INB).

Species distinguished by the large leaflets with relatively few secondary veins and the small multivalved tuberculate/ribbed capsule. 


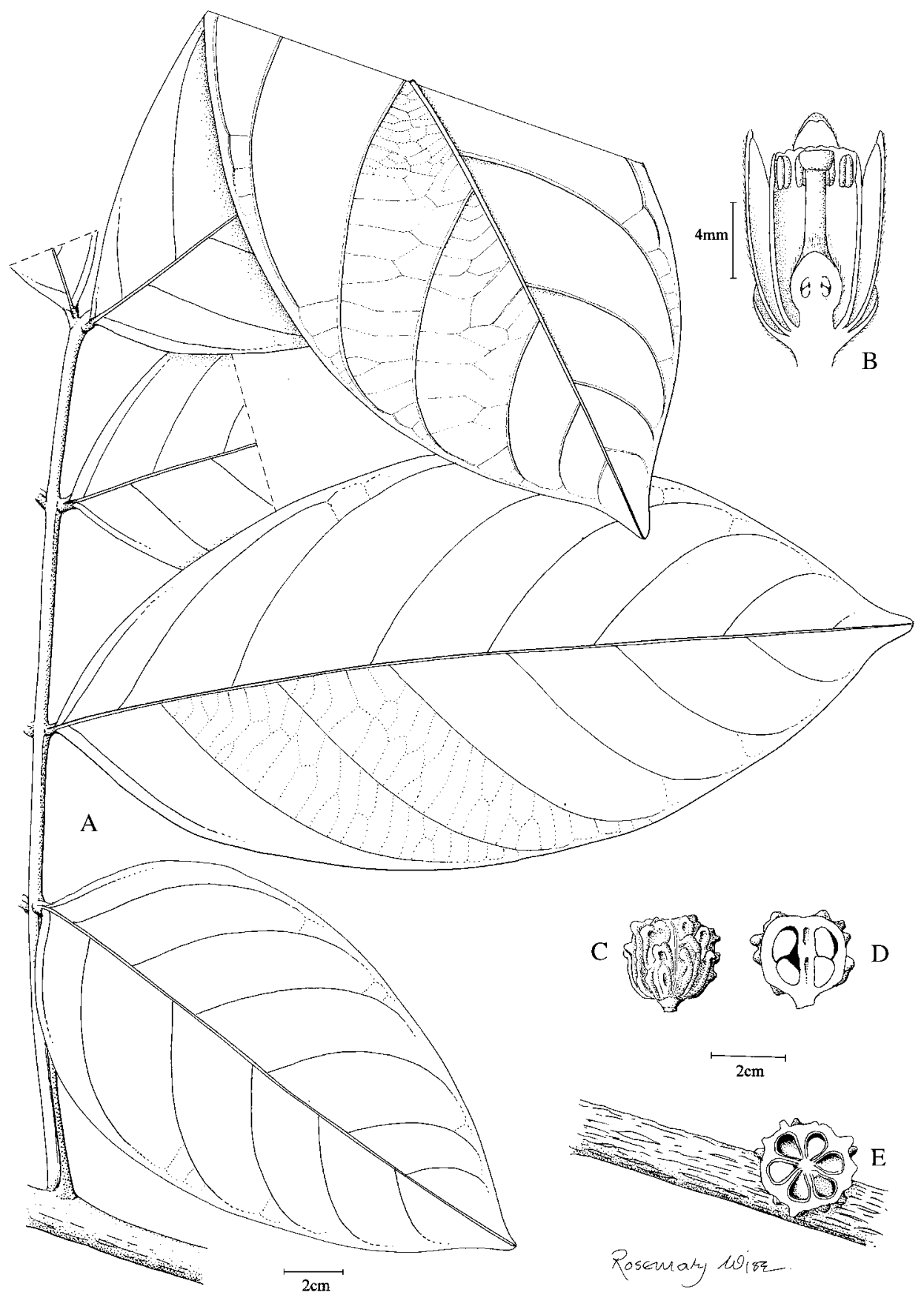

FIG. 37. Guarea corticosa Al.Rodr. A, leaf; B, half-flower; C, fruit; D, longitudinal section of fruit; E, cross-section of fruit. (A-C, E, Aguilar 488; D, Cordero 253). 
50. Guarea crispa T.D.Penn. in T.D.Penn. et al., Fl. Neotrop. 28: 311, fig. 63 (1981). - Type: Brazil, Amazonas, Manaus to Caracarai, km 28, fl., Prance, Pena \& Ramos 3061 (holo INPA; iso F, FHO, GH, K, S). Fig. 50A.

Abbreviated description. Young shoots and inflorescences densely crisped-puberulous, twigs suberous and longitudinally fissured, leaves with a terminal bud showing intermittent growth, leaflets up to 5 pairs, $18-34 \times 8-15 \mathrm{~cm}$, broadly oblong or broadly elliptic, coriaceous, upper surface puberulous along the midrib, lower surface densely entangled- and crisped-puberulous, inflorescence axillary, $15-30 \mathrm{~cm}$ long, a pyramidal thyrse, petals $4-5$, valvate, c. $12.5 \mathrm{~mm}$ long, sericeous outside, staminal tube c. $9 \mathrm{~mm}$ long, c. $5 \mathrm{~mm}$ broad, anthers 8 , ovary 4-locular, locules 1-ovulate, capsule $2.6-2.8 \mathrm{~cm}$ long, $2.7-3 \mathrm{~cm}$ broad, \pm globose, apex truncate, base obtuse to rounded, smooth, densely puberulous, 4-valved, pericarp 2-3 mm thick, valves 1-seeded.

Distribution and ecology. Known only from central Brazilian Amazonia, where it is a component of non-flooded lowland forest.

Additional collections examined. BraziL. Amazonas: Dist. Agropecuario, Reserva 1501 (km 41) (SW0259), Boom et al. 8712 (K, NY); BR-174, km 72, Fazenda Dimona (SW0260), da Silva (INPA/WWF 2206.1225.2) (K); Fazenda Porto Alegre, Reserva 3304 (SW0259), Pacheco et al. $223(\mathrm{~K})$.

51. Guarea donnell-smithii C.DC., Bull. Herb. Boissier, Sér. 2, 5: 419 (1905). - Type: Costa Rica, Boca Culebra, fl., Pittier 12093 (holo CR; iso G, NY (fragment), US; photo K). Figs 38, 60D.

Guarea glabra auct. non Vahl: T.D.Penn. in T.D.Penn. et al., Fl. Neotrop. 28: 269 (1981), p.p.

Young shoots $2-4 \mathrm{~mm}$ diam., densely pilose-setose at first, becoming glabrous, smooth, pale whitish, without lenticels. Leaves pinnate with an active terminal bud, petiole $2-6 \mathrm{~cm}$ long, semiterete at first, becoming terete with age, pilose-setose at first, becoming glabrous, rhachis eventually up to $12 \mathrm{~cm}$ long, semiterete, pilosesetose at first, becoming glabrous; petiolule 2-3 mm long. Leaflets opposite, 1-4 pairs, 6-19 $\times 2.2-7.6 \mathrm{~cm}$, elliptic or less frequently oblanceolate, apex narrowly acuminate to caudate, base acute, sometimes slightly asymmetric, chartaceous, upper surface glabrous except for pilose-setose midrib, lower surface sparsely pilose-setose on midrib and veins and with scattered hairs on the lamina, drying pale green, sometimes sparsely glandular-striate; venation eucamptodromous, midrib slightly sunken on the upper surface, secondaries (6-)10-12 pairs, ascending, slightly arcuate, slightly convergent, slightly sunken on the upper surface, intersecondaries absent, tertiaries few, oblique, parallel. Inflorescence axillary, 2-10 cm long, a few- and rather lax-flowered panicle with short lateral branches, sparsely setose-pilose; pedicel 1.5-2 $\mathrm{mm}$ long (above the articulation). Flowers unisexual (plant dioecious). Calyx 1-1.5 mm long, patelliform, with 4 shallow teeth or lobes, densely setose-pilose. Petals 4, 5-6 $\times 1-1.5 \mathrm{~mm}$, strap-shaped, apex acute, free, valvate, pilose-setose outside, glabrous inside. Staminal 


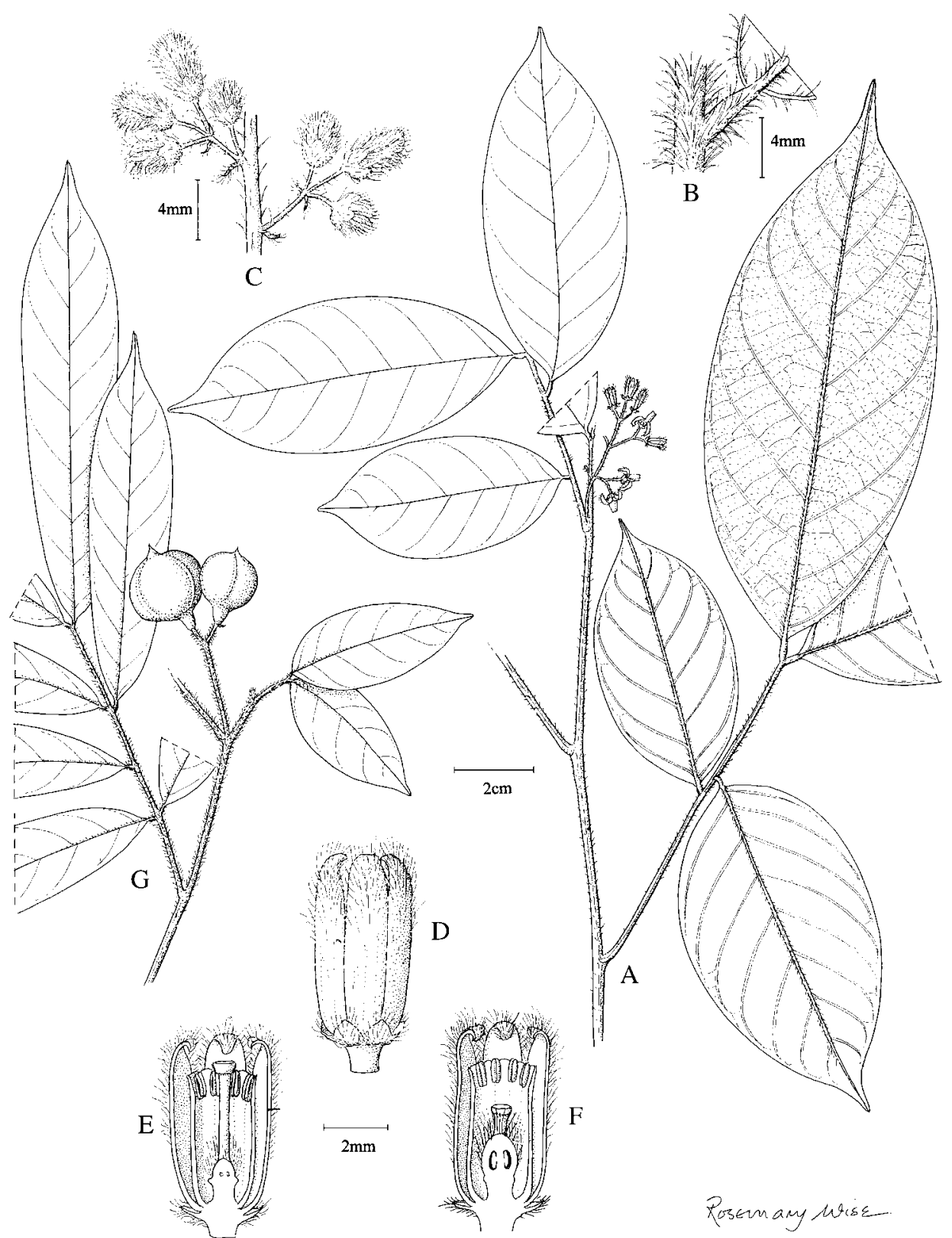

FIG. 38. Guarea donnell-smithii C.DC. A, habit; B, detail of indumentum; C, inflorescence; D, flower; E, half-flower (male); F, half-flower (female); G, fruit. (A, E, Rodriguez et al. 2140; B, G, Brant \& Hazlett 2884; C, Rodriguez 7015; D, F, Pittier 13032).

tube $4.4 .5 \mathrm{~mm}$ long, 4-angled in section, margin entire or slightly irregular, glabrous; anthers 8 , c. $1 \mathrm{~mm}$ long, oblong, glabrous, antherodes in female similar size but indehiscent and without pollen. Nectary in male a stipe c. $1 \mathrm{~mm}$ long expanded into 
a small collar below the ovary, glabrous, less evident in female. Ovary c. $2 \mathrm{~mm}$ long, globose, 4-locular, locules 1-ovulate, sparsely pilose-setose, in male more slender and with rudimentary ovules, style c. $2.5 \mathrm{~mm}$ long, glabrous, style-head discoid, about equalling the stamens. Capsule c. $1.8 \times 1.5 \mathrm{~cm}$, globose, with a rounded apiculate apex and narrowed at the base to a short stipe 3-4 mm long, 4-valved, valves 1-seeded, pericarp c.1 mm thick, glabrous, smooth. Seeds 1-4, shaped like the segment of an orange; embryo not seen.

Field characters. Usually a small understorey treelet flowering when only a few metres high, but also recorded as a $25 \mathrm{~m}$ high tree. The flowers are pink or red and the mature fruit is red. Flowering occurs in January and February, with mature fruit in April and July. The mature fruit are sometimes accompanied by some flowering branches.

Distribution and ecology. Along the Atlantic drainage of Guatemala and Honduras and the Pacific drainage of Costa Rica, in lowland and lower montane rain forest from sea level to $1150 \mathrm{~m}$ altitude.

Collections examined. Guatemala. Izabal: 7 miles S of Puerto Barrios (NW1588), Croat 41809 (K).

Honduras. Yoro: Municipio Yoro, $0.9 \mathrm{~km}$ E of San José Texiguat, $3.5 \mathrm{~km}$ up R. Texiguat (NW1587), Brant \& Hazlett 2884 (K).

Costa Rica. San José: Cantón Pérez Zelendón, Cuenca del Barú, Tinamaste, Finca Tinamaste (NW0983), Rodríguez et al. 2140 (CR, MO), 2629 (CR); Cantón Perez Zelendón, Barú (NW0983), Estrada et al. 849 (CR); Cuenca del Savegre, Río Nuevo, El Brujo (NW0983), Rodríguez et al. 7015 (CR, MO).

This poorly known species occupies part of the range of Guarea chiricana (a member of the Guarea glabra complex) and is morphologically very close to it. Further collections may show them to be conspecific. They share many vegetative, floral and fruit characters, such as leaf shape, venation, texture, floral formula and fruit size. The only significant difference is the presence in Guarea donnell-smithii of coarse pilose-setose indumentum on the young shoots, calyx and outside of the petals. The petals and staminal tube of Guarea donnell-smithii are slightly shorter than those of G. chiricana. The Guatemala specimen cited above has much narrower leaflets than the type from Costa Rica, but the Honduran collection has both narrow leaflets and elliptic leaflets like those of the type.

52. Guarea eriorhachis Harms, Notizbl. Bot. Gart. Berlin-Dahlem 10: 244 (1928); T.D.Penn. in T.D.Penn. et al., Fl. Neotrop. 28: 357 (1981). - Type: Peru, Amazonas, mouth of R. Santiago [SW0477], fl., Tessmann 4450 (holo B, destroyed; iso F (fragment), MO (fragment)). Figs 39, 55D.

Leaves pinnate with a terminal bud showing intermittent growth, petiole $\mathrm{c} .13 .5 \mathrm{~cm}$ long, semiterete above and slightly winged at the base, densely hirsute-villose (hairs 1-2 mm long), rhachis 50-60 cm long, semiterete, hirsute; petiolule 3-4 mm long, 


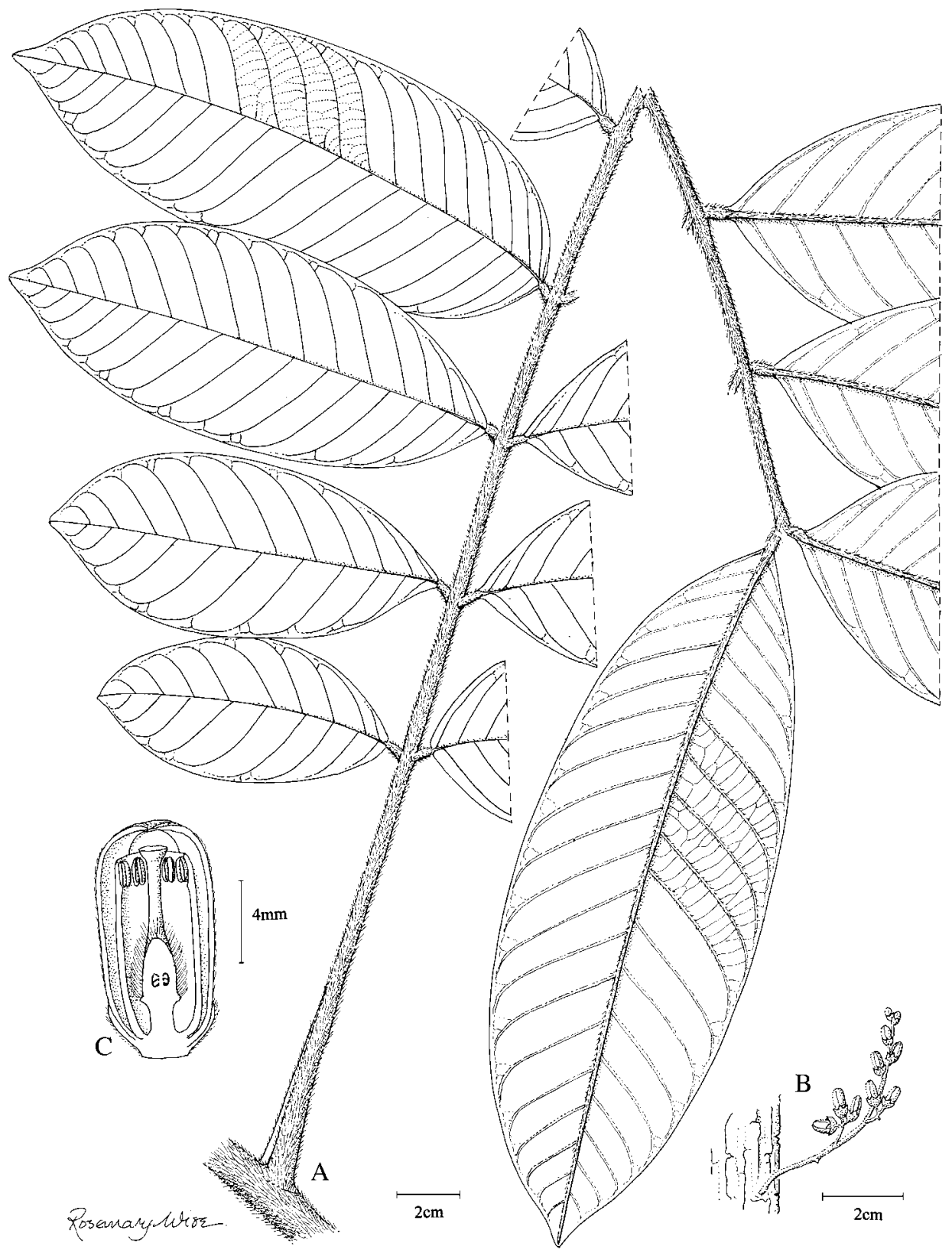

FIG. 39. Guarea eriorhachis Harms. A, habit; B, inflorescence; C, half-flower. (A-C, Schunke 5707). 
densely hirsute-villose. Leaflets opposite, up to 8 pairs, $28-38 \times 8.2-11 \mathrm{~cm}$, oblanceolate, apex obtusely cuspidate, base acute, chartaceous, upper surface with pubescent midrib, otherwise glabrous, lower surface with densely hirsute-villose midrib and veins, sparser on the lamina, not glandular-punctate or -striate; venation eucamptodromous, midrib sunken on the upper surface, secondaries c.20 pairs, ascending, straight or slightly arcuate, parallel or slightly convergent, intersecondaries short or absent, tertiaries oblique, parallel. Inflorescence cauliflorous, 4-11 cm long, a slender panicle, with a few lateral branches to $2 \mathrm{~cm}$ long near the base, tomentose, ebracteate; pedicel c. $1 \mathrm{~mm}$ long. Calyx cyathiform, 3-3.5 mm long, with 4 shallow, broadly ovate, obtuse lobes, pubescent outside, glabrous inside. Petals 4 , valvate, free, $12-13 \mathrm{~mm}$ long, 2-3 mm broad, strap-shaped, apex acute, appressed pubescent outside, glabrous inside. Staminal tube $10-11 \mathrm{~mm}$ long, 3-3.5 mm broad, margin truncate, glabrous; anthers 8, c. $1.5 \mathrm{~mm}$ long, glabrous. Nectary a stout stipe 1-1.5 mm long, expanded below the ovary, glabrous. Ovary c. $3 \mathrm{~mm}$ long, ovoid, 4-locular, locules with 2 superposed ovules, densely covered in long stiff hairs, style 2-3 mm long, glabrous, style-head discoid. Fruit unknown.

Field characters. Treelet to $8 \mathrm{~m}$ high, with terminal clusters of large leaves, flowers with greenish yellow calyx and white petals. Flowering November to December.

Distribution and ecology. Known only from Amazonian Peru, where it is an understorey treelet of non-flooded lowland rain forest, up to $700 \mathrm{~m}$ altitude.

Collections examined. Peru. San Martín: Mariscal Caceres, Tocache Nuevo, Palo Blanco (SW0876), Schunke 5707 (F, K).

This species is morphologically similar to Guarea casimiriana, but differs in the far fewer secondary veins, smaller flowers and fewer ovary locules. The two species also have a different indumentum: that of Guarea eriorhachis is long, lax hirsute-villose, whereas that of G. casimiriana is hispid with stiff hairs. After studying more material of Schunke 5707, we are reasonably confident of placing it in this species. In its vegetative and floral morphology it is a close match to Harms' description.

\section{Guarea grossa T.D.Penn., sp. nov. Figs 40, 61 A.}

A speciebus aliis capsula pergrandi, 5-6-valvata, valvae costis 3, crassis convexis grosse tuberculatis distinguenda. - Type: Costa Rica, Limón, Tortuguero National Park, Tortuguero-Sierpe basin, Lomas de Sierpe, $1.5 \mathrm{~km} \mathrm{~W}$ of National Park Post on R. Sierpe [NW1083], fr., viii 1988, Robles, Herrera \& Flores 2016 (holo K; iso INB).

Young shoots 6-7 mm diam., finely appressed puberulous, smooth, brown. Leaves pinnate, terminal bud ?fallen, petiole $6-9 \mathrm{~cm}$ long, narrowly winged at the base, finely appressed puberulous, rhachis $20-25 \mathrm{~cm}$ long, terete, subglabrous; petiolule 7-10 mm long. Leaflets opposite, 5-6 pairs, the largest (terminal) c. $18-19 \times 6-7 \mathrm{~cm}$, elliptic to oblong, apex acuminate, base narrowly attenuate or acute, chartaceous, 


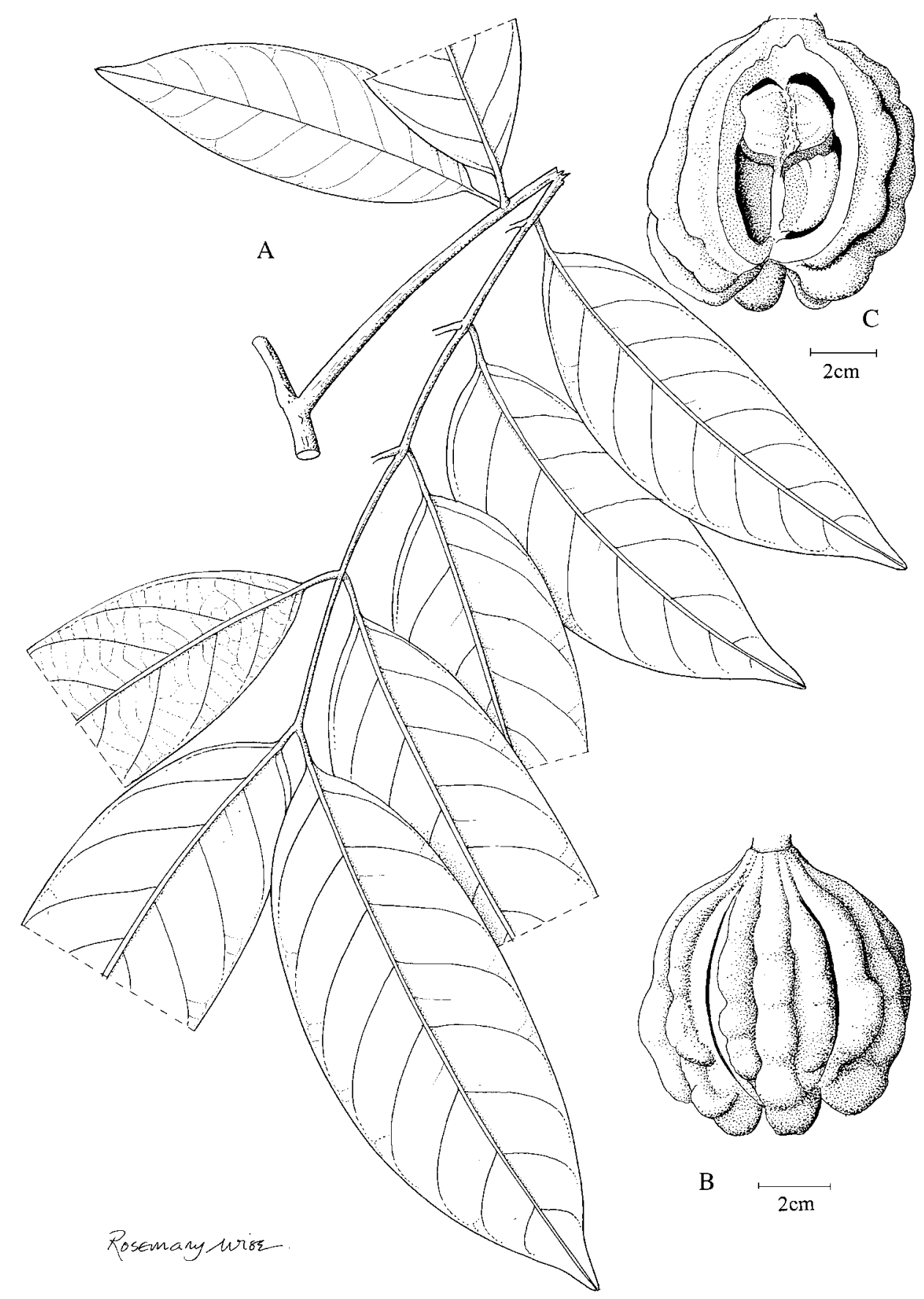

FIg. 40. Guarea grossa T.D.Penn. A, leaf; B, fruit; C, longitudinal section of fruit. (A-C, Robles et al. 2016). 
glabrous, not glandular-punctate or -striate; venation eucamptodromous, midrib flat on the upper surface, secondaries 9-10 pairs, ascending, slightly arcuate and convergent, intersecondaries short to moderately long, tertiaries oblique, obscure. Flowers unknown. Capsule ?solitary, 9.5-10.5 $\times 9-9.5 \mathrm{~cm}$, broadly pyriform, apex depressed, tapering at the base to a short thick annulus c. $2.5 \mathrm{~cm}$ broad, 5-6-valved, pericarp woody when dry, $0.8-1.2 \mathrm{~cm}$ thick, each valve with 3 longitudinal convex ribs, the central one longer than the 2 lateral ones and coarsely branched and tuberculate towards the apex, ribs $0.8-1.5 \mathrm{~cm}$ broad, glabrous, valves with 2 superposed seeds. Seeds c. $3 \times 2 \times 2 \mathrm{~cm}$, truncate at apex or base, completely surrounded by a thick fleshy sarcotesta. Seed coat thin, cotyledons free, superposed, radicle abaxial and slightly exserted.

Field characters. Unbuttressed tree to $25 \mathrm{~m}$ high, with smooth bark. According to the field data, the fresh fruit measure $15 \times 15 \mathrm{~cm}$. There is no information on fruit colour, dehiscence or dispersal. Fruiting occurs in August.

Distribution and ecology. Known only from a single collection on the Caribbean drainage of Costa Rica. It was collected in lowland rain forest on well-drained slopes, around $100 \mathrm{~m}$ altitude.

The general form and venation of the leaves of this species is similar to that of the widespread Guarea grandifolia, which also has a multilocular fruit with 2 superposed seeds in each valve. However, the capsule of Guarea grossa is much larger and very distinct in the prominent rounded and tuberculate ribs.

54. Guarea hoffmanniana C.DC. in A.DC. \& C.DC., Monogr. Phan. 1: 570 (1878); T.D.Penn. in T.D.Penn. et al., Fl. Neotrop. 28: 357 (1981). - Type: Costa Rica, Heredia, Pedregal, Wendland ['Hoffmann'] 755, fl. (holo B, destroyed; lecto GOET n.v. (photos seen), designated by Grayum (2006: 1007); isolecto F, GH, MO n.v.). See Grayum (2006: 1007) for commentary. Fig. 55E.

Guarea macropetala T.D.Penn. in T.D.Penn. et al., Fl. Neotrop. 28: 349, fig. 74 (1981). - Type: Panama, Province Panamá, El Llano to Carti road, fl., Nee \& Tyson 10989 (holo MO; iso K, NY).

Abbreviated description. Young shoots golden-tomentose or villose, inflorescence golden puberulous, leaves with a terminal bud showing intermittent growth, leaflets up to 5 pairs, $14.5-23 \times 5-9 \mathrm{~cm}$, broadly oblong or oblanceolate, sparsely to densely pubescent on midrib and veins, lamina generally glabrous, upper surface bearing numerous minute raised dots, secondaries 11-14 pairs, inflorescence cauliflorous, solitary or paired, a raceme or slender panicle, with a few short lateral branches at the base, petals 4 , valvate, 15-18 mm long, golden sericeous outside, staminal tube 10-13 mm long, anthers 10-13, 2-2.2 mm long, ovary 7-10-locular, locules with 2 superposed ovules, capsule c. $5.5 \times 6 \mathrm{~cm}$, broadly pyriform, strongly depressed at the apex, tapering at the base, contracted between the valves when dry and somewhat 
tuberculate, puberulous, 7-10-valved, valves with 2 superposed seeds, pericarp 5$7 \mathrm{~mm}$ thick.

Distribution and ecology. Costa Rica and Panama, in lowland and lower montane rain forest up to $700 \mathrm{~m}$ altitude.

Additional collections examined. Costa Rica. Heredia: Cantón Sarapiqui, La Virgen (NW1083), Zamora et al. 2535 (INB); Rio Puerto Viejo, Finca la Selva (NW1084), Folsom 9843 (F), Grayum 1146 (F). Limón: Guápiles, Finca las Laureles de Corinto (NW1083), Pennington \& Zamora 13343 (CR, K).

Panama. Bocas del Toro: Fortuna Dam region (NW0882), McPherson 8413 (K); road towards Chiriquí Grande (NW0882), McPherson 12547 (K). Cocle: between Caño Blanco del Norte, Caño Sucio and Chorro del Rio Tife (NW0880), Davidse \& Hamilton 23533 (K, MEXU). Colón: Santa Rita Ridge (NW0979), McPherson 10244 (K). San Blas: El LlanoCarti road km 19.1 (NW0978), de Nevers et al. 5202 (K), 5366 (K), 5869 (K).

55. Guarea humaitensis T.D.Penn. in T.D.Penn. et al., Fl. Neotrop. 28: 306, fig. 62 (1981). - Type: Brazil, Amazonas, Manaus to Porto Velho road, km 345, fl., Pennington, Prance, Ramos \& Monteiro 9995 (holo INPA; iso FHO, NY). Fig. 50B.

Abbreviated description. Young shoots and inflorescences puberulous to pubescent, leaves with a dormant terminal bud without intermittent growth, leaflets 5-7 pairs, $(14-) 20-27.5(-31) \times 5.9-8.8(-9.5) \mathrm{cm}$, usually oblanceolate, rarely elliptic or oblong, thinly coriaceous, with some pubescence along the lower midrib, otherwise glabrous, secondary veins 11-16 pairs, inflorescence axillary or on twigs below the leaves, 10-30(-40) cm long, a laxly-branched panicle, lower lateral branches to $10 \mathrm{~cm}$ long, petals 4-5, valvate, 9-13 mm long, staminal tube (7-)8-11 mm long, (2-)3-6 mm broad, anthers 8-9, ovary 4-5-locular, locules 1-ovulate, capsule $1.8-3 \mathrm{~cm}$ long, globose to ovoid, apiculate, base contracted into a short stipe c. $0.5 \mathrm{~cm}$ long, 4 5-valved, each valve with 3-5 longitudinal wrinkled ribs, puberulous, pericarp c. $2 \mathrm{~mm}$ thick, valves 1 -seeded.

Distribution and ecology. Central to western Amazonian Brazil, in non-flooded lowland rain forest. A single recent collection from French Guiana (Prévost \& Grenand 4329) may belong to this species, but without flowers or fruit it cannot be placed with certainty.

Additional collections examined. BRAzil. Amazonas: Manaus, Reserva Florestal Ducke (SW0259), Assunção \& Vicentini 1 (K), Assunção et al. 809 (K); Municipio de Novo Aripuaná BR 230, 400 km from Humaita (SW0760), Cid Ferreira 5920 (K); Dist. Agropecuario, Reserva 1501, km 41 (SW0259), Freitas et al. 536 (K); km 26 Manaus - Itacoatiara road, Ducke Reserve (SW0259), Gentry et al. 69064 (K), Gentry \& Nelson 69276 (K); Municipio Manaus, $90 \mathrm{~km} \mathrm{~N}$ of Manaus, Fazenda Dimona (SW0260), Kukle 72 (K, NY); Dist. Agropecuario, Reserva 1501 WWF/INPA project (SW0259), Oliveira et al. 164 (K), Pacheco et al. 118 (K); Manaus, Ducke Reserve (SW0259), Sothers 213 (K), Sothers \& Silva 659 (K). 
56. Guarea inesiana Al.Rodr., Lankesteriana 6: 109 (2006). - Type: Costa Rica, San José, Desamparados, Cuenca del Reventazon, Cerros de la Muerte [NW0983], fr., A. Rodríguez 9624 (holo INB). Fig. 61B.

Young shoots 7-8 $\mathrm{mm}$ diam., finely puberulous, becoming glabrous, pale brown, lenticellate. Leaves pinnate with intermittent apical growth, petiole 5-6 cm long, semiterete, glabrous, rhachis up to $20 \mathrm{~cm}$ long, semiterete, glabrous; petiolule 1.2$1.5 \mathrm{~cm}$ long, swollen. Leaflets opposite, up to 5 pairs, $17-26 \times 6-9 \mathrm{~cm}$, broadly oblong to oblanceolate, apex obtuse to shortly cuspidate, base acute to narrowly cuneate, coriaceous, glabrous except for tufts of hair in the axils of the secondary veins below; venation eucamptodromous, midrib not raised or sunken on the upper surface, secondaries 10-11 pairs, steeply ascending, mostly \pm straight, parallel to slightly convergent, intersecondaries short or absent, tertiaries oblique, numerous. Inflorescence on twigs below the leaves, 5-8 cm long, a pyramidal panicle, subglabrous; pedicel 1-2 $\mathrm{mm}$ long (above the articulation). Calyx shallowly cup-shaped, 2-3 mm long, irregularly toothed or lobed, subglabrous. Petals 4, 11-12 mm long, strap-shaped, apex acute, glabrous apart from sparse minute appressed hairs near the apex. Staminal tube 10-11 mm long, 4-5 mm broad, margin truncate, glabrous; anthers 8-9, c.1.5 mm long, glabrous. Nectary c. $1.5 \mathrm{~mm}$ long, glabrous. Ovary 4-locular, locules with 2 superposed ovules, subglabrous, style-head discoid. Capsule 7-7.5 cm diam., globose, apex and base rounded, 4-valved, valves smooth, densely lenticellate, glabrous, pericarp (when dry) 1.3$1.5 \mathrm{~cm}$ thick, valves with 2 superposed seeds. Seeds c. $2 \mathrm{~cm}$ long, plano-convex; embryo with plano-convex, superposed cotyledons, radicle abaxial, extending to the surface.

Field characters. Tree to $30 \mathrm{~m}$ high with scaling bark and pink slash, leaves up to $50 \mathrm{~cm}$ long. Flowers cream, anthers brown and fruit maturing red. Flowering recorded in March, mature fruit in June.

Distribution and ecology. Costa Rica, on the Pacific slopes of the Cordillera Central and on the Cordillera de Talamanca, in montane rain forest between $1740 \mathrm{~m}$ and $2000 \mathrm{~m}$ altitude.

Collections examined. Costa Rica. Alajuela: Reserva Forestal Grecia, Bosque Eterno de los Niños, Sendero Pinares (NW1084), L.D. Vargas 1233 (INB).

Morphologically close to Guarea kunthiana, and differing from it only in the presence of hair tufts in the vein axils on the lower leaflet surface. Similar large-fruited forms of Guarea kunthiana are known from high altitude forest in the Andean countries.

57. Guarea juglandiformis T.D.Penn. in T.D.Penn. et al., Fl. Neotrop. 28: 301, fig. 61 (1981). - Type: Brazil, Acre, road Cruzeiro do Sul to Japiim, km 18, fl., Prance, Pena \& Ramos 2837 (holo INPA; iso FHO, NY, S). Fig. 50C.

Abbreviated description. Young shoots closely appressed puberulous and papillose, leaves with indeterminate apical growth, leaflets $2-7$ pairs, $16-22 \times 5-7 \mathrm{~cm}$, oblong, 
elliptic or lanceolate, base narrowly attenuate, chartaceous, lower surface puberulous, secondary veins $10-12$ pairs, tertiary venation easily visible, inflorescence up to $35 \mathrm{~cm}$ long, a slender thyrse, petals 4 , valvate, c. $5.5 \mathrm{~mm}$ long, staminal tube c. $4 \mathrm{~mm}$ long, c. $1.25 \mathrm{~mm}$ broad, anthers 8 , ovary 4-locular, locules 1-ovulate, capsule $2.5-3 \mathrm{~cm}$ long, globose to broadly pyriform, 4-valved, each valve with 3 slender, convoluted and anastomosing wings, up to $7 \mathrm{~mm}$ deep, sparely puberulous, pericarp (excluding wings) $2-5 \mathrm{~mm}$ thick, valves 1 -seeded.

Distribution and ecology. Western Amazonian Brazil and Amazonian Peru, in nonflooded lowland forest on lateritic soils, below $400 \mathrm{~m}$ altitude.

Additional collections examined. Peru. Loreto: Maynas, Nauta-Iquitos (SW0473), Ayala 1690 (NY); Iquitos-Nauta km 28 (SW0373), Rimachi 11842 (NY), 12160 (NY); Iquitos-Nauta km 48 (SW0473), Vásquez 7122 (NY); Allpahuayo, IIAP Station (SW0373), Vásquez et al. 13825 (MO, QCNE), van der Werff et al. 10247 (MO).

Brazil. Amazonas: Municipio de Novo Aripuaná, BR230, 300 km from Humaitá (SW0760), Cid Ferreira 5712 (K); 400 km from Humaitá (SW0760), Cid Ferreira 5973 (K). Rondonia: Municipio Costa Marqués, BR-429, INCRA project Porto Murtinho (SW1263), Cid Ferreira 8646 (K).

58. Guarea lozanii M.E.Morales, Rev. Acad. Colomb. Cienc. 22(84): 336 (1998). - Type: Colombia, Vaupés, Municipio de Taraira, Caparú Biological Station, $3 \mathrm{~km}$ N of Lake Taraira [SW0169], fl., Defler 295 (holo COAH; iso COAH, MO). Fig. 56A.

Young shoots pubescent at first, soon glabrous, c.1 cm diam., smooth, brown. Leaves pinnate with a terminal bud, petiole $17-20 \mathrm{~cm}$ long, channelled on the upper surface, subglabrous, rhachis 35-40 cm long, terete, glabrous; petiolule 4-5 mm long, swollen. Leaflets opposite, 6-7 pairs, 28-33 × 7-9.4 cm, oblanceolate, apex narrowly acuminate, base acute to narrowly cuneate, chartaceous, upper surface with pubescent midrib, lower surface glabrous, not glandular-punctate or -striate; venation eucamptodromous, midrib sunken on the upper surface, secondaries 23-24 pairs, ascending, slightly arcuate, slightly convergent, intersecondaries absent, tertiaries oblique, obscure. Inflorescence ramiflorous, 5-18 cm long, a slender panicle with some lateral branches near the base to $1 \mathrm{~cm}$ long, flowers subtended by small ovate bracts $\mathrm{c} .1 \mathrm{~mm}$ long; pedicel 4-10 mm long. Calyx cup-shaped, 4-5 mm long, 4-5-lobed to about 1/2 its length, sparsely puberulous. Petals 4-6, valvate, c. $10 \times 2 \mathrm{~mm}$, strap-shaped, apex acute, finely appressed puberulous outside, glabrous inside. Staminal tube c. $7 \times 2 \mathrm{~mm}$, margin entire, glabrous; anthers 9-11, c.1.5 mm long, oblong, with a short terminal appendage, dehiscent, glabrous. Nectary c. $2 \mathrm{~mm}$ long, a stout stipe expanded below the ovary, glabrous. Ovary narrowly ovoid, 6-locular, locules with 1 ovule, sparsely pubescent, style sparsely pubescent below, glabrous above, slightly shorter than the staminal tube, style-head discoid. Fruit unknown.

Field characters. Tree to $15 \mathrm{~m}$ high and $16 \mathrm{~cm}$ diam., flowering in August. 
Distribution and ecology. Described from lowland rain forest in Amazonian Colombia, with a second possible record from lowland Amazonian Peru.

Collections examined. Peru. Ucayali: Pucallpa-Tingo Maria km 84, von Humboldt Reserve (SW0875), Pennington et al. 17066 (K, MOL).

Without fruit, the relationships of this species remain doubtful. In general leaf and floral morphology it is similar to both Guarea venenata and G. purusana, but both these species generally have biovulate ovary locules and somewhat larger flowers. Guarea lozanii has anthers terminated by a short appendage, and this is also occasionally seen in G. purusana. The ovary of Guarea lozanii is slightly longitudinally ribbed, which may indicate that it has a winged or ribbed fruit. If so, then this would place the species in the vicinity of Guarea caulobotrys or G. fistulosa.

\section{Guarea megacostata T.D.Penn., sp. nov. Figs 41, 66C.}

Guarea grandifoliae affinis sed ovario 4-loculare, loculis uniovulatis, capsula 4-valvata, manifeste 12-costata differt. - Type: Venezuela, Carabobo, above headwaters of R. San Gian, E of Los Tanques, S of Borburata [NW1067], fr., iii 1966, J.A. \& C. Steyermark 95392 (holo K; iso US).

Young shoots massive, $1.5-2.5 \mathrm{~cm}$ diam., densely and coarsely tomentose with pale hairs, becoming glabrous, without lenticels. Leaves pinnate with an active terminal bud, petiole 15-20 cm long, deeply channelled above at base to slightly channelled at apex, rhachis 15$25 \mathrm{~cm}$ long, slightly channelled above, petiole and rhachis pubescent at first, becoming glabrous; petiolules swollen, c.5 mm long. Leaflets opposite, 1-3 pairs, first pair 17$17.5 \times 12.5-13.5 \mathrm{~cm}$, suborbicular, apex truncate, base rounded, subsequent pairs 25 $30 \times 11.5-13.5 \mathrm{~cm}$, broadly oblong-elliptic, apex rounded, base acute to obtuse, coriaceous, upper surface glabrous, lower surface with sparsely pubescent midrib, not glandular-punctate or -striate; venation eucamptodromous, midrib flat or slightly sunken, secondaries 10-12 pairs, ascending, straight or slightly arcuate, parallel, intersecondaries absent, tertiaries numerous, oblique; higher order reticulum obscure. Inflorescence borne below the leaves. Flowers not seen. Capsule pendulous on a peduncle at least $7 \mathrm{~cm}$ long (incomplete), c. $5 \times 4 \mathrm{~cm}$ (according to field data the mature fruit is 7-8 cm long and 6-7 $\mathrm{cm}$ broad), obovoid, apex obtuse, tapering to an acute base, 4-valved, pericarp woody, 7-8 mm thick, each valve bearing 3-4 thick prominent longitudinal ribs, 3-4 mm high, finely appressed puberulous; valves 1 -seeded. Seed c. $2.3 \times 1 \mathrm{~cm}$, ellipsoid, apex rounded, base acute, completely surrounded by a thin fleshy sarcotesta. Seed coat thin, cotyledons superposed, radicle abaxial, extending to the surface.

Field characters. Tree to $15 \mathrm{~m}$ high with pendent fruit on elongated peduncles. The fruit matures wine-red. Fruiting in March.

Distribution and ecology. Known only from evergreen lower montane forest in Carabobo and Falcón, Venezuela, at an altitude between $750 \mathrm{~m}$ and $1100 \mathrm{~m}$.

Collections examined. Venezuela. Falcón: road Riecita - La Mina (NW1068), Cardozo 147 (K). 


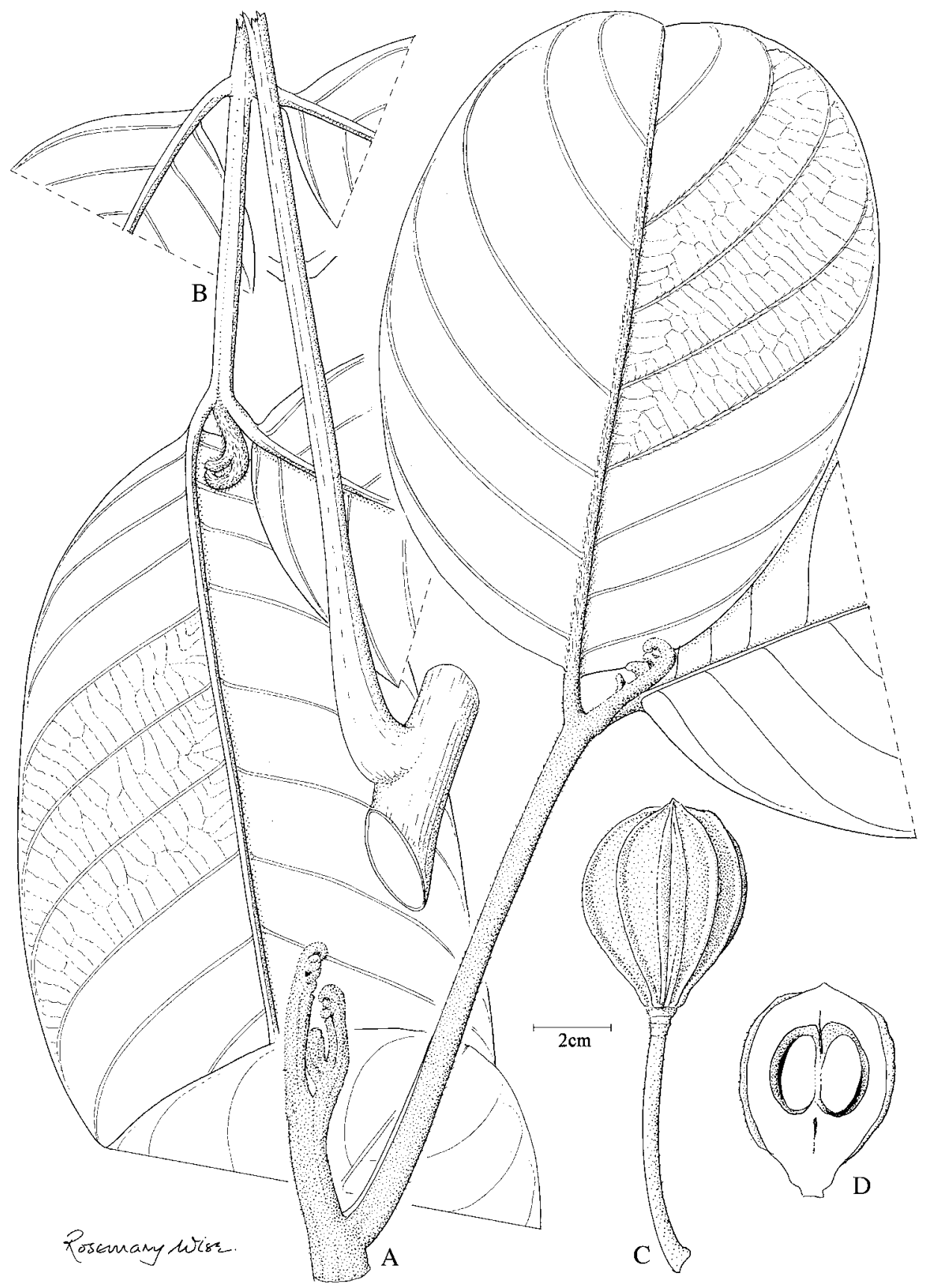

FIG. 41. Guarea megacostata T.D.Penn. A, B, habit; C, fruit; D, longitudinal section of fruit. (A-D, Steyermark, J. A. \& C. 95392). 
The large size and form of the leaves of this species are similar to those of the widespread Guarea grandifolia, but it differs from that species in its uniformly 4-locular ovary with uniovulate loculi (ovary (4-)7-8(-10)-locular, loculi with 2 superposed ovules in G. grandifolia), and in the strongly ribbed capsule (smooth or only faintly lined in G. grandifolia).

Guarea carinata has a somewhat similar fruit but it differs in its more numerous ovary loculi, each with 2 superposed ovules, and in its smaller leaflets and distinctive indumentum.

60. Guarea mexicana Coronado, Novon 16: 465 (2006). - Type: Mexico, Chiapas, Bochil, road from Bochil to Simojovel, 4.5 miles NE of Bochil, Breedlove 10220 (holo NY). Figs 42, 61C.

Young shoots 4-5 mm diam., shortly pubescent at first, becoming glabrous, often longitudinally striate (when dry), becoming smooth, pale greyish-buff, with a few large lenticels. Leaves pinnate with a terminal bud showing intermittent growth, petiole $3.5-6 \mathrm{~cm}$ long, semiterete, shortly pubescent, rhachis up to $12 \mathrm{~cm}$ long, semiterete, shortly pubescent; petiolule $4-5 \mathrm{~mm}$ long, shortly pubescent. Leaflets opposite, up to 4 pairs, 14.2-22.5 $\times 3.9-5.2 \mathrm{~cm}$, oblong to oblong-elliptic, apex shortly acuminate, base acute to obtuse and sometimes slightly asymmetric, margin slightly recurved near the base, coriaceous, upper surface glabrous, lower surface shortly pubescent along the midrib and secondary veins, not glandular-punctate or -striate; venation eucamptodromous, midrib sunken on the upper surface, secondary veins 8-10 pairs, ascending, arcuate, slightly convergent, intersecondaries short or absent, tertiaries oblique to perpendicular, venation rather conspicuous on both surfaces (when dry). Inflorescence axillary, 3-6 cm long, a slender panicle with short lateral branches to $1.5 \mathrm{~cm}$ long, shortly pubescent; pedicel c.1 mm long. Flowers unisexual (plant dioecious) (male flowers only seen). Calyx 3-3.5 mm long, cup-shaped, 4-lobed for $1 / 3$ to $1 / 2$ its length, lobes ovate, obtuse or rounded, subglabrous. Petals 4 , c. $8 \times 2 \mathrm{~mm}$, strap-shaped, apex acute, finely appressed puberulous outside, glabrous inside. Staminal tube broadly cylindrical, 6-6.5 × $3 \mathrm{~mm}$, margin undulate, glabrous; anthers 8, c. $1 \mathrm{~mm}$ long, oblong, glabrous. Nectary a stout stipe 1-1.5 mm long, slightly expanded below the ovary, glabrous. Ovary ovoid, c. $1.5 \mathrm{~mm}$ long, 4-locular, locules uniovulate (rudimentary in male), glabrous, style $2.5-3 \mathrm{~mm}$ long, style-head discoid. Capsule c. $2.5 \mathrm{~cm}$ diam., globose, apex rounded or truncate, base rounded, 4-valved, valves 1-seeded, pericarp rough and densely lenticellate, glabrous. Seeds not seen.

Field characters. Tree to $18 \mathrm{~m}$ high, flowering in May, with mature fruit in December.

Distribution and ecology. Southeastern Mexico (Chiapas) where it occurs in lower montane rain forest over limestone, associated with Quercus, Billia, Persea, Nectandra, Aphananthe, Turpinia and Calatola, altitudinal range 900-1000 m. According to 


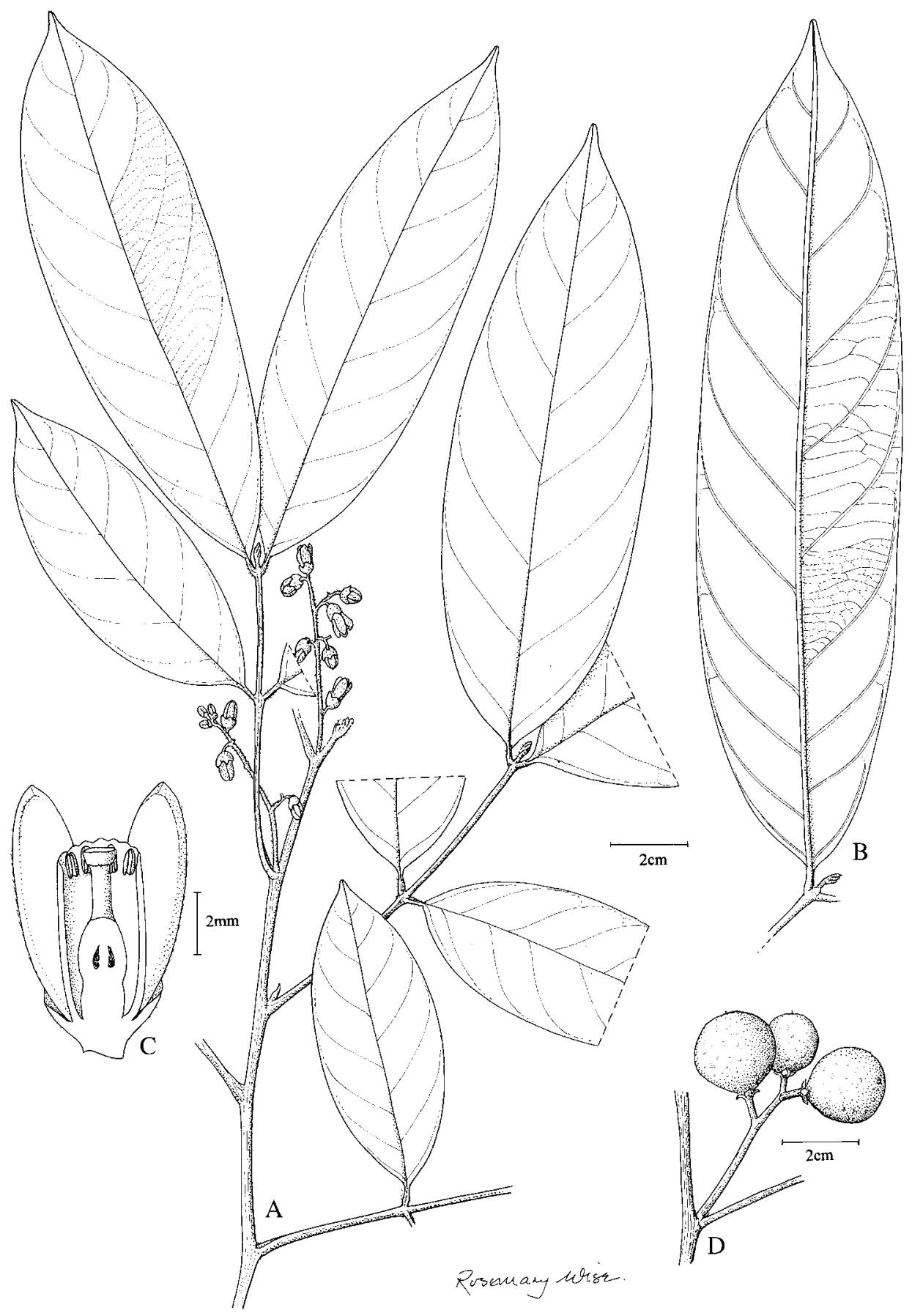

FIG. 42. Guarea mexicana Coronado. A, habit; B, leaflet; C, half-flower; D, fruit. (A, D, Breedlove \& Thorne 30774; B, Breedlove 20245; C, Breedlove 35320). 
Coronado it also occurs in Honduras (Williams \& Molina 14655), but we have not seen this specimen.

Collections examined. Mexico. Chiapas: $13 \mathrm{~km} \mathrm{~N}$ of Berriozabal, near Pozo Turipache and Finca El Suspiro (NW1693), Breedlove 20245 (F, MO), 35320 (MO, NY), Breedlove \& Smith 21678 (MO), Breedlove \& Thorne 30774 (MO).

This species probably belongs in the Guarea glabra complex. Its leaf morphology is similar to that of Guarea glabra subsp. glabrescens, except that it has fewer secondary veins and it also differs in its larger flowers with a glabrous ovary. The floral morphology is closest to Guarea bijuga, but it differs from this in its pubescent petals. The leaflets of Guarea mexicana are more slender than those of G. bijuga, and pubescent along the lower midrib and secondary veins.

61. Guarea polymera Little, J. Wash. Acad. Sci. 38: 98 (1948); T.D.Penn. in T.D.Penn. et al., Fl. Neotrop. 28: 318, fig. 65 (1981). - Type: Ecuador, Esmeraldas, S of Playa de Oro, fl., Little 6404 (holo US; iso F, K, NY, U, Y). Fig. 56B.

For synonymy see T.D.Penn. in T.D.Penn. et al., Fl. Neotrop. 28: 318 (1981).

Abbreviated description. Young shoots and inflorescences minutely papillose, leaves with a dormant non-active terminal bud, leaflets (3-)4-7 pairs, 20-30 × 5-8.8 cm, oblong to oblanceolate, thinly coriaceous, glabrous above, minutely appressed puberulous below, venation eucamptodromous, inflorescence axillary, 10-36 cm long, a broad, laxly-branched and laxly-flowered panicle, lowest lateral branches to $12 \mathrm{~cm}$ long, petals 5-7, valvate, $10-15 \mathrm{~mm}$ long, staminal tube, contracted at the throat, c. $8 \mathrm{~mm}$ long, 5-7 mm broad, anthers 10-11, ovary 6-7-locular, locules with 2 superposed ovules, minutely appressed puberulous, capsule $3-4 \mathrm{~cm}$ diam., globose, smooth, densely papillose, 6-7-valved, pericarp 3-4 $\mathrm{mm}$ thick, valves with 2 superposed seeds.

Distribution and ecology. Pacific drainage of Colombia and Ecuador where it is confined to lowland rain forest, up to $500 \mathrm{~m}$ altitude.

Additional collections examined. Colombia. Chocó: Municipio de Pizarro, Rio Pepe (NW0577), Espina 2059 (MO); Baudo (NW0477), Fuchs \& Zanella 22356 (US). Nariño: TumacoTuquerres, E of Llorente (NW0178), Gentry 34931 (COL).

EcuAdor. Esmeraldas: San Lorenzo, Awa Reserva (NW0178), C. Aulestia 942 (MO, NY); El Siléncio (NW0079), Cornejo \& Bonifaz 6603 (K); San Miguel, Rio Cayapas, Loma Linda (NW0078), Tipaz et al. 2276 (MO); San Miguel, Limones, Rio Grande (NW0078), Tipaz et al. 2283 (K); Eloy Alfaro, Cotocachi Cayapas Reserve, San Miguel (NW0078), Tipaz 2480 (NY, QCNE), 2652 (QCNE).

62. Guarea reticulatovenosa T.D.Penn., sp. nov. Figs 43, 56C.

Guarea sprucei affinis sed foliolorum nervibus secundariis 23-26-jugis, inflorescentia cauliflora, ovario 4-loculare, fructu stipitato leviter costato differt. - Type: 


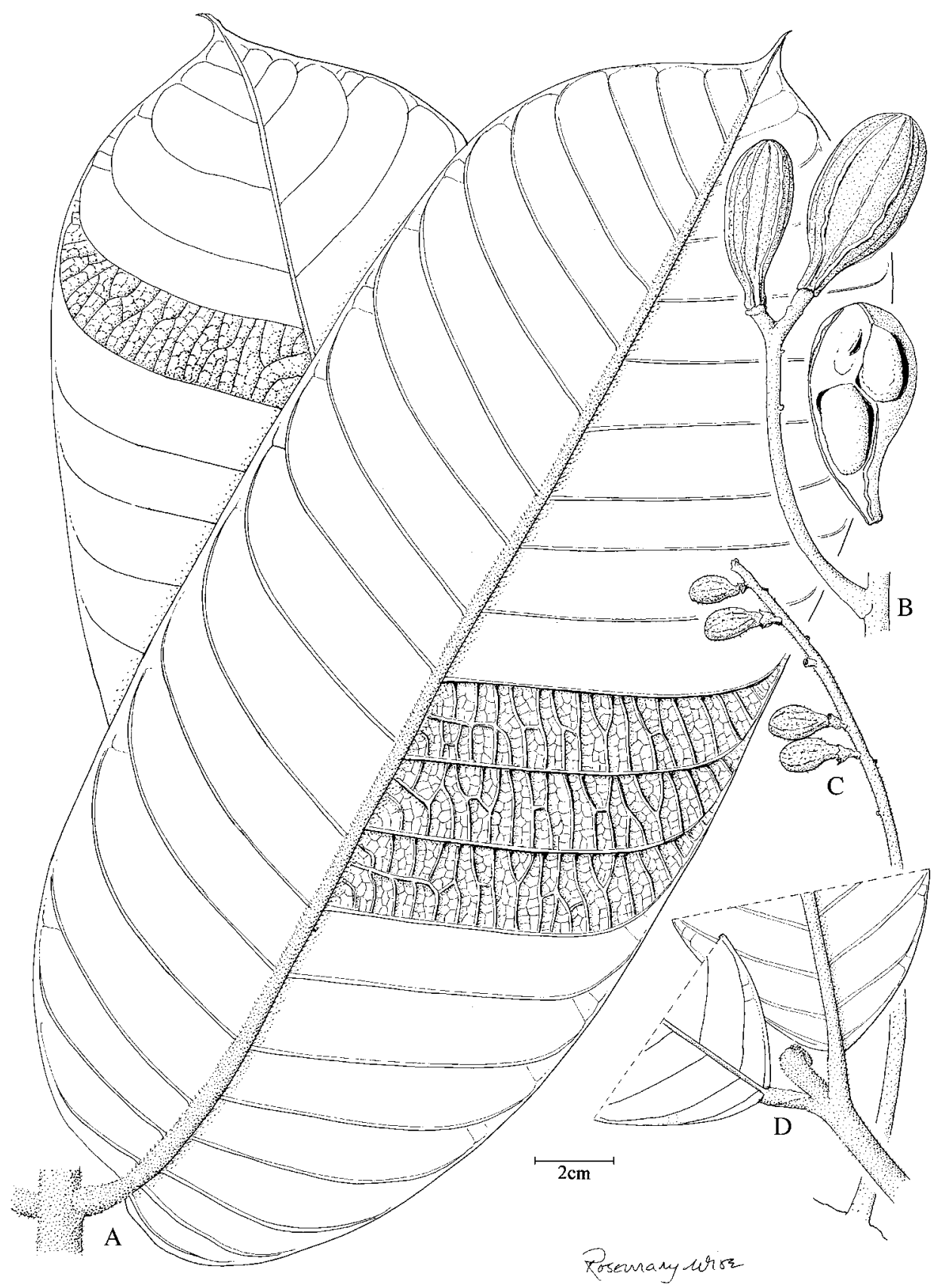

FIG. 43. Guarea reticulatovenosa T.D.Penn. A, leaflet; B, infructescence and fruit section; C, young infructescence; D, leaf apex with dormant bud. (A, B, Forero et al. 7202; C, D, Franco et al. 1302). 
Colombia, Department Chocó, Municipio San José del Palmar, valley of R. Torito (affluent of R. Habita) [NW0476], 850-1000 m altitude, fr., iii 1980, E. Forero, R. Jaramillo, J. Espina \& P. Palacios 7202 (holo MO).

Young shoots coarsely tomentose. Leaves pinnate with a terminal bud, exact length not known, but probably 40-50 cm long; petiole not seen, rhachis semiterete, at least $30 \mathrm{~cm}$ long (incomplete), 6-8 mm diam., densely golden pubescent; petiolule 1.2$1.5 \mathrm{~cm}$ long, swollen, densely pubescent, incomplete leaf with 2 pairs of leaflets. Leaflets opposite, $34-48 \times 11.5-14.5 \mathrm{~cm}$ broad, broadly oblong to slightly oblanceolate, apex obtusely cuspidate to acuminate, base acute, obtuse or rounded, coriaceous and bullate, conspicuously reticulate-venose, upper surface glabrous, lower surface coarsely golden-pubescent on midrib and veins, hairs intermixed with some minute red papillae, not glandular-punctate or -striate; venation eucamptodromous in the lower two thirds, brochidodromous in the upper third, midrib slightly sunken, secondaries 23-26 pairs, shallowly ascending, slightly arcuate and \pm parallel, short intersecondaries present, tertiaries oblique and parallel, numerous and very prominent on the lower surface (bullate); higher order reticulum evident on both surfaces. Inflorescence cauliflorous, 18-20 cm long, a slender panicle with very short lateral branches, shortly pubescent; pedicel (in specimens with young fruit) 2-3 mm long. Flowers not seen. Capsule c. $5 \times 2.5 \mathrm{~cm}$, broadly oblong, apex obtuse to rounded, tapering at the base into a stout stipe c. $1 \mathrm{~cm}$ long, 4-valved, valves shallowly and irregularly longitudinally 3-ribbed, ribs anastomosing in upper half, finely puberulous, pericarp c. $2 \mathrm{~mm}$ thick, apparently fleshy, valves slightly constricted between the seeds, 2 superposed seeds in each valve, c. $2 \times 1.1 \mathrm{~cm}$ long, slightly plano-convex, completely surrounded by a thin fleshy sarcotesta. Seed coat thin and fleshy.

Field characters. A little-branched treelet to $7 \mathrm{~m}$ high, cauliflorous, fruit maturing red, the seed with a yellowish sarcotesta. Fruiting in March.

Distribution and ecology. In wet lower montane rain forest between $850 \mathrm{~m}$ and $1100 \mathrm{~m}$ altitude, on the eastern slopes of the western Cordillera of the Andes, in the department of Chocó, Colombia.

Collections examined. Colombia. Chocó: vereda 'La Holanda' (NW0476), Franco et al. 1302 (COL, MO).

The strongly bullate reticulate leaflets of Guarea reticulatovenosa are similar to those of G. sprucei (Amazonian Brazil), but somewhat larger and with more secondary veins. It also differs from Guarea sprucei in its cauliflorous inflorescence, flowers with 4-locular ovary, and the broadly oblong fruit narrowed to a stout stipe at the base, and fruit valves with 3 very shallow anastomosing ribs. 
63. Guarea rhopalocarpa Radlk., Bull. Herb. Boissier, Sér. 2, 5: 191 (1905); T.D.Penn. in T.D.Penn. et al., Fl. Neotrop. 28: 350 (1981). - Type: Costa Rica, Cartago, Tuis, fr., Tonduz 11306 (holo CR; iso G, GH, NY, P, US). Figs 44, 56D. Guarea montana Al.Rodr., Lankesteriana 6: 111 (2006), syn. nov. - Type: Costa Rica, Puntarenas, Cordillera de Tilarán, Monteverde Biological Station, San Luís, Buen Amigo, track to Veracruz, fl., Z. Fuentes 653 (holo INB; iso CR n.v., MO). For further synonymy see T.D.Penn. in T.D.Penn. et al., Fl. Neotrop. 28: 350 (1981).

Abbreviated description. Young shoots and inflorescences minutely appressed puberulous, leaves with a terminal bud showing intermittent growth, leaflets up to 5 pairs, $12.5-24 \times 4.8-9.5 \mathrm{~cm}$, broadly oblong, oblanceolate or elliptic, chartaceous, glabrous above, but with numerous minute raised dots, lower surface puberulous to glabrous, secondary veins $9-12$ pairs, inflorescence mostly cauliflorous or ramiflorous, $10-30 \mathrm{~cm}$ long, a densely-flowered pendulous spike, raceme or narrow panicle, petals 4-6, valvate, 9.5-14 mm long, minutely appressed puberulous, staminal tube $8-12.5 \mathrm{~mm}$ long, anthers 8-9, ovary 4-5(-6)-locular, locules with 2 superposed ovules, capsule 4 $8 \mathrm{~cm}$ long, 3-4 cm broad, pyriform to ellipsoid, usually with a long tapering base, densely papillose-puberulous, 4-5-valved, valves broadly and shallowly 3-ribbed, ribs sometimes torulose, pericarp 6-10 mm thick, valves with 2 superposed seeds.

Distribution and ecology. Costa Rica and Panama to the frontier with Colombia, in lowland and montane rain forest up to $1500 \mathrm{~m}$ altitude.

Representative additional collections. Costa Rica. Alajuela: Monteverde Reserve, Rio Peñas Blancas (NW1084), Haber \& Bello 7904 (CR, K); Cantón de Upala, PN Guanacaste (NW1085), Chavarria 1198 (INB). Guanacaste: $3 \mathrm{~km} \mathrm{~N}$ of Santa Elena, Atlantic Exposure (NW1084), Haber ex Bello 3809 (CR); Estación Pitilla, La Cruz, Guanacaste National Park (NW1085), Moraga 346 (INB, K). Heredia: $9 \mathrm{~km}$ SW of Las Horquetas, Rio Sardinal (NW1084), Grayum et al. 5019 (MO). Limón: Braulio Carillo, beyond Rio Sucio (NW1083), Gomez et al. 22766 (K). Puntarenas: Monteverde, San Luis, Finca Buen Amigo (NW1084), Fuentes 267 (INB, K).

Panama. Bocas del Toro: Fortuna Dam Area, Oleoducto road (NW0882), Churchill et al. 4533 (K). Chiriquí: Quebrada Bonita, Fortuna Hydroelectric Project (NW0882), Galdames et al. 643 (K). Cocle: above El Cope (NW0880), McPherson 13624 (K). Darien: Pirre Massif, Alturas de Nique, above Cana mine (NW0777), McPherson 12192 (K). Veraguas: vicinity of Cerro Tute, (NW0881), McPherson 10671 (K).

Colombia/Panama. Chocó/Darien: Alto de Nique, Cerro Pirre massif (NW0777), Gentry et al. $28693(\mathrm{~K})$.

Guarea montana is here reduced to synonymy. The characters used to justify separation in the protologue of Guarea montana are both minute and inconsistent. For example the 'stipels' present at the petiole apex of Guarea rhopalocarpa (which are actually a minute extension of the petiole margin) are rapidly caducous and therefore easily missed, and they are also present in some specimens cited as G. montana (e.g. Alfaro $57(\mathrm{~K})$ ). Similarly the inflorescence of Guarea montana is said to be a narrow thyrse, or sometimes apparently a raceme, differing from the 'strictly racemose' inflorescence of G. rhopalocarpa. Examination of a range of specimens of 


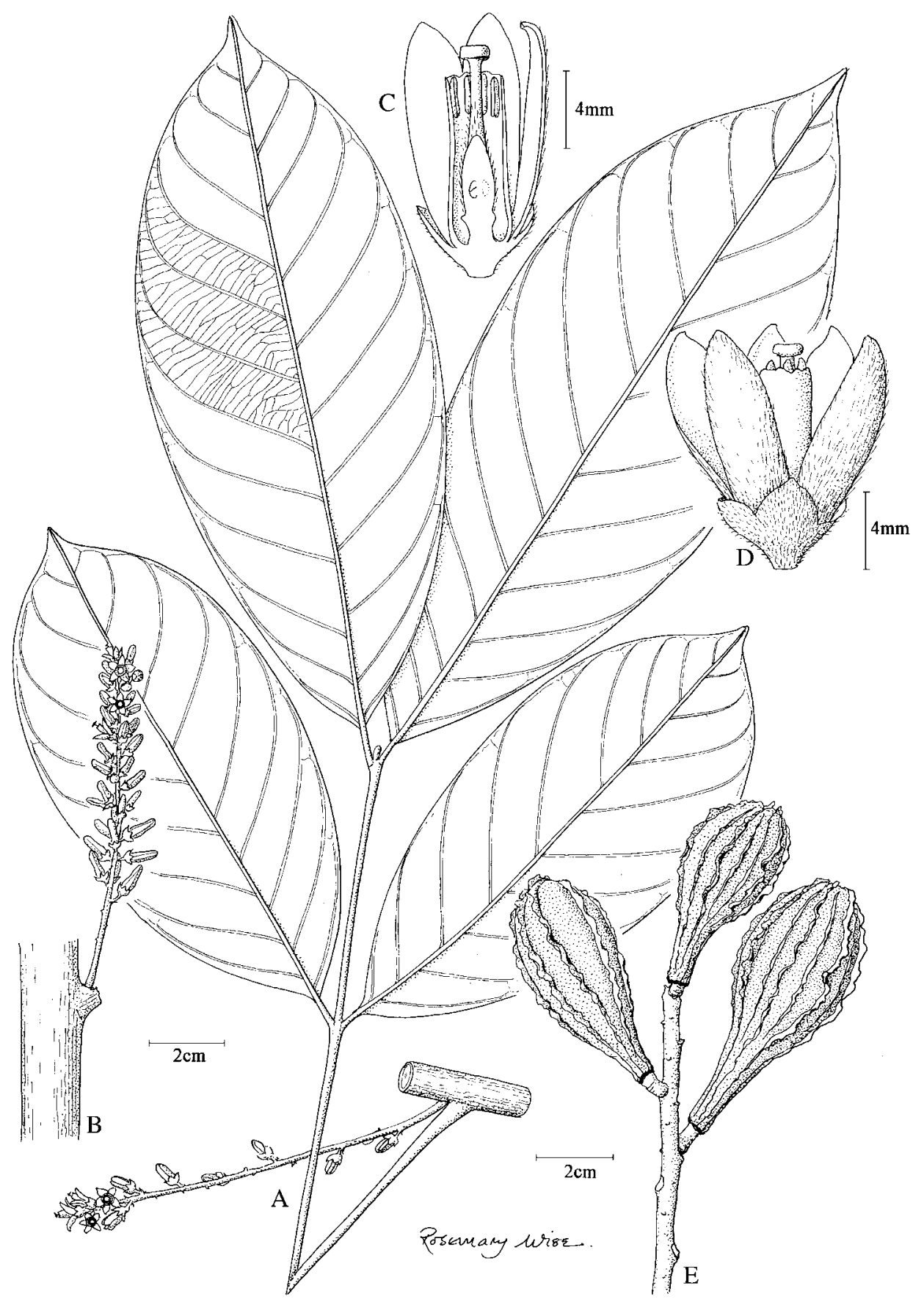

FIG. 44. Guarea rhopalocarpa Radlk. A, habit; B, inflorescence, C, half-flower; D, flower; E, infructescence. (A, Chacon 246; B-D, Neill 5116; E, Grayum et al. 5019). 
Guarea rhopalocarpa reveals a complete gradation from spike to raceme to narrow thyrse. Guarea montana occupies the same geographical area and ecological and altitudinal zones and they flower at the same time of year.

64. Guarea scabra A.Juss., Bull. Sci. Nat. Géol. 23: 239 (1830); A.Juss., Mém. Mus. Hist. Nat. 19: 241, 285 (1831); T.D.Penn. in T.D.Penn. et al., Fl. Neotrop. 28: 304 (1981). - Type: Cayenne (French Guiana), fr., Collector unknown s.n. (holo P-JU; iso P). Figs 45, 50D.

Abbreviated description. Young shoots and inflorescences minutely appressed puberulous, leaves with a terminal bud showing intermittent growth, leaflets up to 6 pairs, 12.5-22.5 × 4-7.5 cm, elliptic, oblong or oblanceolate, chartaceous, glabrous, inflorescence ramiflorous (on smaller branches), or less frequently axillary, 3.5-20 cm long, a laxly-branched thyrse, the lower lateral branches to $10 \mathrm{~cm}$ long, petals $4-5$, valvate, (7-)9.5-12 mm long, staminal tube (5.5-)7.5-9.5 mm long, 2-3 mm broad, anthers $8-9$, ovary 4(-5)-locular, locules 1 -ovulate, capsule $2-2.2 \mathrm{~cm}$ long, globose to broadly pyriform, slightly constricted between the seeds on drying, apex truncate, base rounded or tapered, 4-valved, smooth (see note below), minutely puberulous mixed with some longer pubescence, pericarp 2-3 mm thick, valves 1-seeded.

Distribution and ecology. Venezuela and the Guianas to central and western Amazonian Brazil and Peru, in non-flooded lowland rain forest.

Additional collections examined. Venezuela. Amazonas: Depto. Atabapo, between Duida and Marahuaca (NW0365), Liesner 25567 (K); Serrania de Tapirapeca (NW0164), Marín 1905 (K); Misión Río Mavaca (NW0265), Stergios et al. 15329 (K); Depto. Atabapo, Rio Purumane (NW0366), Yanez 495 (K).

Guyana. Region Upper Takutu - Upper Essequibo, Kamoa Mts. (NW0158), D. Clarke 3132 (K); Kwitaro River (NW0358), D. Clarke et al. 6311 (K). Region Potaro-Siparuni, Mt. Ayanganna (NW0559), H.D. Clarke et al. 9662 (K); Kaieteur National Park, Potaro River (NW0559), Gillespie et al. 1377 (K); Gunn's, Essequibo River (NW0158), Jansen-Jacobs et al. 1912 (K).

Surinam. Litani R. (NW0254), Acevedo-Rodríguez et al. 5753 (K); Tumuc Humac Mts., Talouakem (NW0254), Acevedo-Rodríguez et al. 5836 (K); Tumuc Humac Mts., Jari River (NW0254), Acevedo-Rodríguez et al. 6090 (K); Sipaliwimi, vicinity of Ulemari River (NW0254), Evans \& Peckham 2859 (K), Hammel et al. 21662 (K).

French Guiana. Saül (NW0353), Mori \& Gracie 21165 (K), 23886 (K), Mori \& Pepper 24300 (K), Mori et al. 24090 (K); Matiti, Point-Quadrat MAT (NW0552), Prévost \& Grenand 4390 (K).

Peru. Loreto: Maynas, Iquitos-Nauta km 45 (SW0473), Vásquez \& Jaramillo s.n. (K). Pasco: Palcazu valley (SW0968), Hartshorn et al. 2669 (K), 2769 (K). San Martín: Mariscal Caceres, Tocache Nuevo (SW0876), Schunke 10061 (K).

Brazil. Acre: Municipio Mancio Lima, Parque Nacional Serra do Divisor (SW0773), Daly et al. 8884 (K). Amapá: Rio Falsino, Reserva INCRA (NW0151), Campbell et al. 14302 (K), 14806 (K); Municipio Macapá, Perimetral Norte (BR 210) (NW0153), Daly et al. 4002 (K); Municipio Macapá Riozinho (NW0153), Mori \& Cardozo 17581 (K); Municipio Macapá, $154 \mathrm{~km} \mathrm{NW}$ of Porto Grande (NW0153), Rabelo et al. 3086 (K, NY); Municipio Macapa, $7 \mathrm{~km}$ NW of Riozinho (NW0153), Rabelo et al. 3125 (K). Amazonas: Vila Bittencourt, Rio Japura (SW0169), Amaral et al. 505 (K); Manaus - Caracarai road km 97 (SW0257), Cid et al. 998 (K); Municipio Novo Airão, Area Indigena Waimiri Atroari (SW0161), 


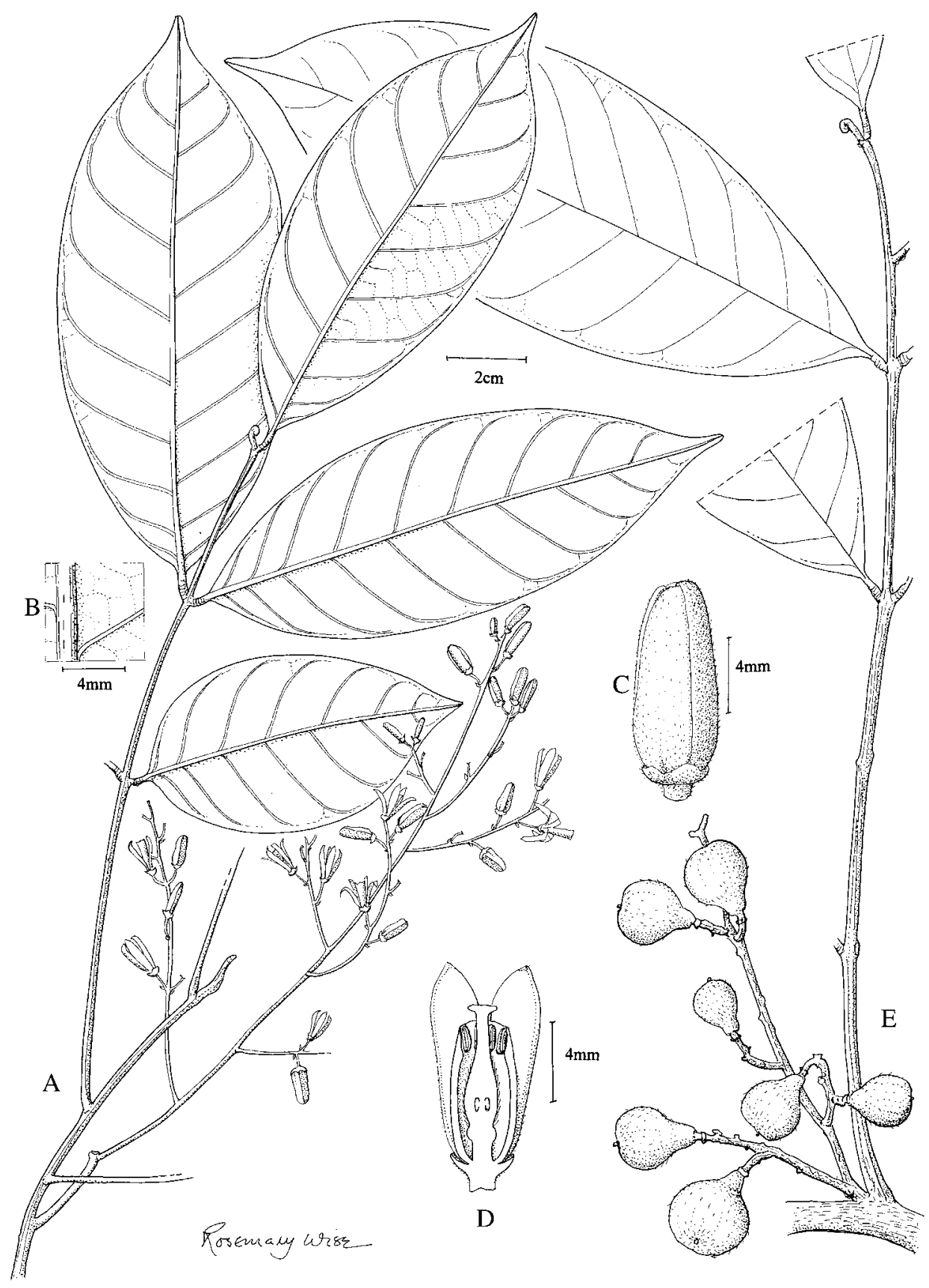

FIg. 45. Guarea scabra A.Juss. A, habit; B, enlargement of leaf undersurface; C, flower bud; D, half-flower; E, infructescence. (A, B, Acevedo-Rodriguez et al. 5753; C, D, Mori et al. 24090; E, Evans \& Peckham 2859). 
Milliken et al. 661 (K); Manaus, Reserva Florestal Ducke (SW0259), Ribeiro et al. 1901 (K). Pará: Ilha do Marajó, R. Anajos (SW0049), Prance et al. 30216 (K).

This species has a smooth capsule. It was incorrectly described as having a 3-4-ribbed capsule by Pennington in Pennington et al. (1981). This was due to an error in the labelling of a separate fruit collection.

65. Guarea sphenophylla Urb., Symb. Ant. 7: 242 (1912); T.D.Penn. in T.D.Penn. et al., Fl. Neotrop. 28: 321, fig. 66 (1981). - Type: Haiti, Massif de la Hotte, Grand Goave, Morne Descassiers, fr., Ekman H9524 (neo S, designated by Pennington in Pennington et al. (1981: 322); iso K, NY). Fig. 66D.

For synonymy see T.D.Penn. in T.D.Penn. et al., Fl. Neotrop. 28: 321 (1981).

Abbreviated description. Young shoots and inflorescences minutely appressed puberulous, leaves with a terminal bud showing intermittent growth, leaflets up to 6 pairs, $5-6.5 \times 2.8-3 \mathrm{~cm}$, oblanceolate, obovate or cuneiform, coriaceous, glabrous, venation eucamptodromous, secondaries 9-11 pairs, inflorescence axillary, 1-3 cm long, few-flowered, complete flowers not seen, anthers 8 , capsule c. $1.5 \mathrm{~cm}$ diam., globose, densely tuberculate-ribbed, sparsely to densely appressed puberulous, 3-4-valved, valves with 1-2 superposed seeds.

Distribution and ecology. Confined to Hispaniola (Haiti and Dominican Republic) on forested hills between $700 \mathrm{~m}$ and $1800 \mathrm{~m}$ altitude. No post-1981 collections have been seen.

66. Guarea subsessilifolia Al.Rodr., Sida 21(4): 2039 (2005). - Type: Costa Rica, San José, Turrubares, San Luís, Faldas del cerro Pelón, fl., Rodríguez 9613 (holo INB). Figs 46, 61D.

Young shoots coarsely pubescent at first, soon glabrous, smooth, greyish brown, 3-4 mm diam. Leaves pinnate with a terminal bud showing intermittent growth, petiole 1-2 mm long, semiterete, coarsely pubescent, rhachis up to $10 \mathrm{~cm}$ long, semiterete, coarsely pubescent to glabrous; petiolule c. $2 \mathrm{~mm}$ long, swollen. Leaflets opposite, 1-3 pairs, $4.2-14.6 \times 1.6-4.5 \mathrm{~cm}$, oblanceolate or elliptic, apex narrowly acuminate, base acute or cuneate, chartaceous, upper surface with pubescent midrib, lower surface with scattered hairs along the midrib, otherwise glabrous, sparsely glandular-striate; basal pair of leaflets much reduced, 1-4.2 $\times 1-3.2 \mathrm{~cm}$, broadly ovate to suborbicular with an asymmetric base; venation eucamptodromous to brochidodromous in the upper half, midrib sunken on the upper surface, secondaries 8-12 pairs, ascending, slightly arcuate and slightly convergent, intersecondaries absent, tertiaries oblique to horizontal. Inflorescence axillary, male $2-6 \mathrm{~cm}$ long, 8-35-flowered, female 1-3 cm long, 4-13-flowered, thyrsoid, coarsely pubescent to glabrous; pedicel 1.5-4 mm long. Calyx (male) 1-1.5 mm long, (female) $0.75-1 \mathrm{~mm}$ long, cup-shaped, shortly 4-lobed, sparsely pubescent. Petals 4, 5-5.5 mm long, valvate, strap-shaped, apex acute, appressed puberulous outside in the upper half. 


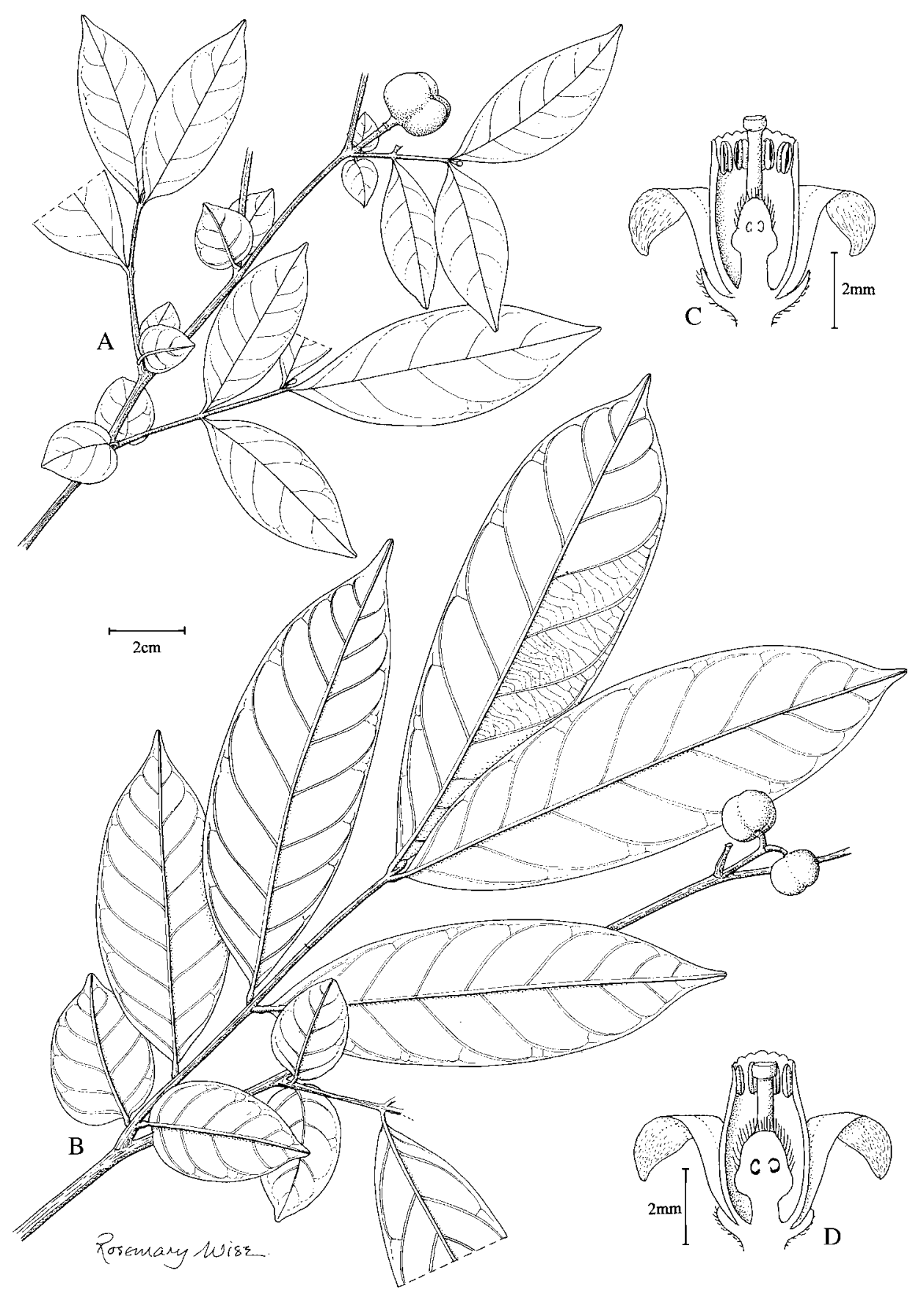

FIG. 46. Guarea subsessilifolia Al.Rodr. A, B, habit with fruit; C, half-flower (male); D, halfflower (female). (A, Zuniga et al. 376; B, Haber et al. 11670; C, D, adapted from Rodriguez (2005)). 
Staminal tube 4-5 mm long, 1.5-2.5 mm broad, margin irregularly dentate, glabrous; anthers 8, 0.75-1 mm long, antherodes without pollen. Nectary c. $1.5 \mathrm{~mm}$ long, a stout stipe expanded below the ovary. Ovary 4-locular, pubescent, locules 1-ovulate, style glabrous, style-head discoid. Capsule 1-1.5 cm long, 1-2 cm broad, \pm globose, apex rounded to truncate, base truncate, 4-valved, smooth, sparsely pubescent to glabrous, valves 1 -seeded, pericarp $0.5-1 \mathrm{~mm}$ thick. Seeds $0.6-0.8 \mathrm{~cm}$ long, surrounded by a thin sarcotesta.

Field characters. Treelet to $4 \mathrm{~m}$ high, the bark with pink slash, flowers pinkish white, capsule maturing reddish green, seed surrounded by an orange sarcotesta. Flowering recorded in May, mature fruit in November.

Distribution and ecology. Species known only from wet montane forest on the Pacific slopes of Costa Rica (Puntarenas and San José), at $850 \mathrm{~m}$ to $1600 \mathrm{~m}$ altitude.

Collections examined. Costa Rica. Puntarenas: Cantón de Puntarenas, Cordillera de Tilarán, Monteverde (NW1084), Haber et al. 11670 (INB, K). San José: Cantón Turrubares, SW spur of Cerro Turrubares (NW0984), Grayum et al. 10551 (INB); Cerro Turrubares, Zona Protectora (NW0984), Jimenez 534 (CR); Turrubares, San Luis, Faldas del Cerro Pelón (NW0984), Rodríguez et al. 9614 (BM); slopes of Cerro Bares, Cerros de Turrubares (NW0984), Zúniga et al. 376 (INB, K).

This species has the floral and fruit structure of Guarea glabra and its relatives, but is easily recognised by the very short petiole and the pair of reduced basal leaflets. Reduced basal leaflets are widespread in the genus Trichilia, but have hitherto been unknown in Guarea.

67. Guarea talamancana Gómez-Laur. \& M.Valerio, Brenesia 38: 147 (1992). - Type:

Costa Rica, Limón, Suretka, La Pera [NW0982], fl., Gómez-Laurito 8820 (holo CR). Fig. 61E.

Young shoots densely golden tomentose, c. $1 \mathrm{~cm}$ diam., indumentum persistent, eventually becoming glabrous, pale buff and suberous, with large pale lenticels. Leaves pinnate with a terminal bud showing intermittent growth, petiole $10-15 \mathrm{~cm}$ long, semiterete, golden-tomentose, rhachis to $55 \mathrm{~cm}$ long, semiterete to terete, tomentose; petiolule swollen, 3-6 mm long. Leaflets opposite, up to 6 pairs, $26-42 \times 11-18 \mathrm{~cm}$, lowermost c. $11 \times 7 \mathrm{~cm}$, broadly oblanceolate, apex obtusely cuspidate, base acute, glabrous above, uniformly softly pubescent below with golden hairs, denser on midrib and veins, chartaceous; venation eucamptodromous, midrib sunken on the upper surface, secondaries 16-19 pairs, steeply ascending, slightly arcuate and convergent, intersecondaries absent, tertiaries oblique. Inflorescence cauliflorous and ramiflorous, c. $2 \mathrm{~cm}$ long, a short spike, flowers subsessile. Calyx c. $2 \mathrm{~mm}$ long, cup-shaped, margin shallowly and irregularly lobed, shortly pubescent outside. Petals 4 , c. $12 \times 2 \mathrm{~mm}$, strapshaped, apex acute, densely short-pubescent outside, glabrous inside. Staminal tube c. $10 \times 2.5 \mathrm{~mm}$, cylindrical, apex undulate, glabrous; anthers 8 , c. $2 \mathrm{~mm}$ long. Nectary a broad stipe c. $1.5 \mathrm{~mm}$ long. Ovary 9-10-locular, locules with 1-2 superposed ovules, 
densely golden-hirsute, style-head capitate. Capsule c. $4 \times 4 \mathrm{~cm}$ (immature), broadly pyriform, apex depressed, base obtuse, 8-valved, strongly 8-winged, the ribs c. $1 \mathrm{~cm}$ deep and rounded dorsally, puberulous. Seeds not seen.

Field characters. Tree to $10 \mathrm{~m}$ high, trunk straight and cylindrical, with cauliflorous inflorescence.

Distribution and ecology. Known only from Costa Rica on the Caribbean slopes of the Cordillera de Talamanca, in rain forest up to $250 \mathrm{~m}$ altitude.

Collections examined. Costa Rica. Limón: Talamanca, Suretka, La Pera (NW0982), GómezLaurito 8380 (CR); Talamanca, Sixaola, Gandoca, Rio Mile Creek (NW0982), Herrera 7656 (CR); Talamanca, Manzanillo, Finca de Bonilla (NW0982), M. Valerio 298 (CR); Talamanca, Reserva Indigena Bribri, Volio (NW0982), Valverde et al. 1157 (CR).

This species is distinct on account of the very large, softly pubescent leaflets, and the 8-valved, deeply ribbed fruit.

68. Guarea trunciflora C.DC. in A.DC. \& C.DC., Monogr. Phan. 1: 571 (1878); T.D.Penn. in T.D.Penn. et al., Fl. Neotrop. 28: 340 (1981). - Type: Poeppig \& Endlicher, Nov. Gen. et Sp. 3: 39, t. 245 (1843) (icon). Figs 47, 50E.

For synonymy see T.D.Penn. in T.D.Penn. et al., Fl. Neotrop. 28: 340 (1981).

Abbreviated description. Young shoots and inflorescences golden tomentose, twigs soon becoming suberised, leaves with a terminal bud showing intermittent growth, leaflets up to 7 pairs, 13-27 $\times 5-11 \mathrm{~cm}$, elliptic, broadly oblong or oblanceolate, chartaceous, \pm glabrous above, uniformly puberulous below with crisped pale whitish hairs intermixed with minute red papillae, secondary veins 13-18 pairs, inflorescence axillary or in the axils of fallen leaves, 3-20 cm long, a laxly-branched pyramidal thyrse, lower branches spreading widely, to $6 \mathrm{~cm}$ long, petals 4(-5), valvate, 11-14 mm long, golden sericeous outside, staminal tube 8.5-10 mm long, ovary 4-5-locular, locules with 2 superposed ovules, capsule $3.5-5 \mathrm{~cm}$ long, 3-3.5 cm broad, pyriform, 4-5-valved, smooth or with faint longitudinal lines when dry, shortly velutinous, valves with 2 superposed seeds, pericarp 5-7 mm thick; seed c. $1.7 \times 1 \mathrm{~cm}$, with plano-convex, superposed cotyledons.

Field characters. Tree to $30 \mathrm{~m}$ high. The mature capsule is red.

Distribution and ecology. Amazonian Colombia and Peru, southern Venezuela and Guyana to central Amazonian Brazil, in non-flooded lowland rain forest over clay or sand.

Additional collections examined. Colombia. Amazonas: Araracuara, Rio Caquetá (SW0072), Alvarez et al. 784 (K). Caquetá: region of Araracuara (SW0072), Restrepo \& Matapi 390 (NY).

Venezuela. Bolívar: Municipio Atures, Rio Parguaza (NW0667), Fernandez 303 (MO).

GuYanA. Upper Takutu-Upper Essequibo, Rewa River (NW0258), D. Clarke 3627 (K); Kaoma Mts. (NW0158), D. Clarke 5004 (K); Acarai Mts. 4 km S of Sipa River (NW0158), D. Clarke et al. 7117 (K), 7719 (K). 


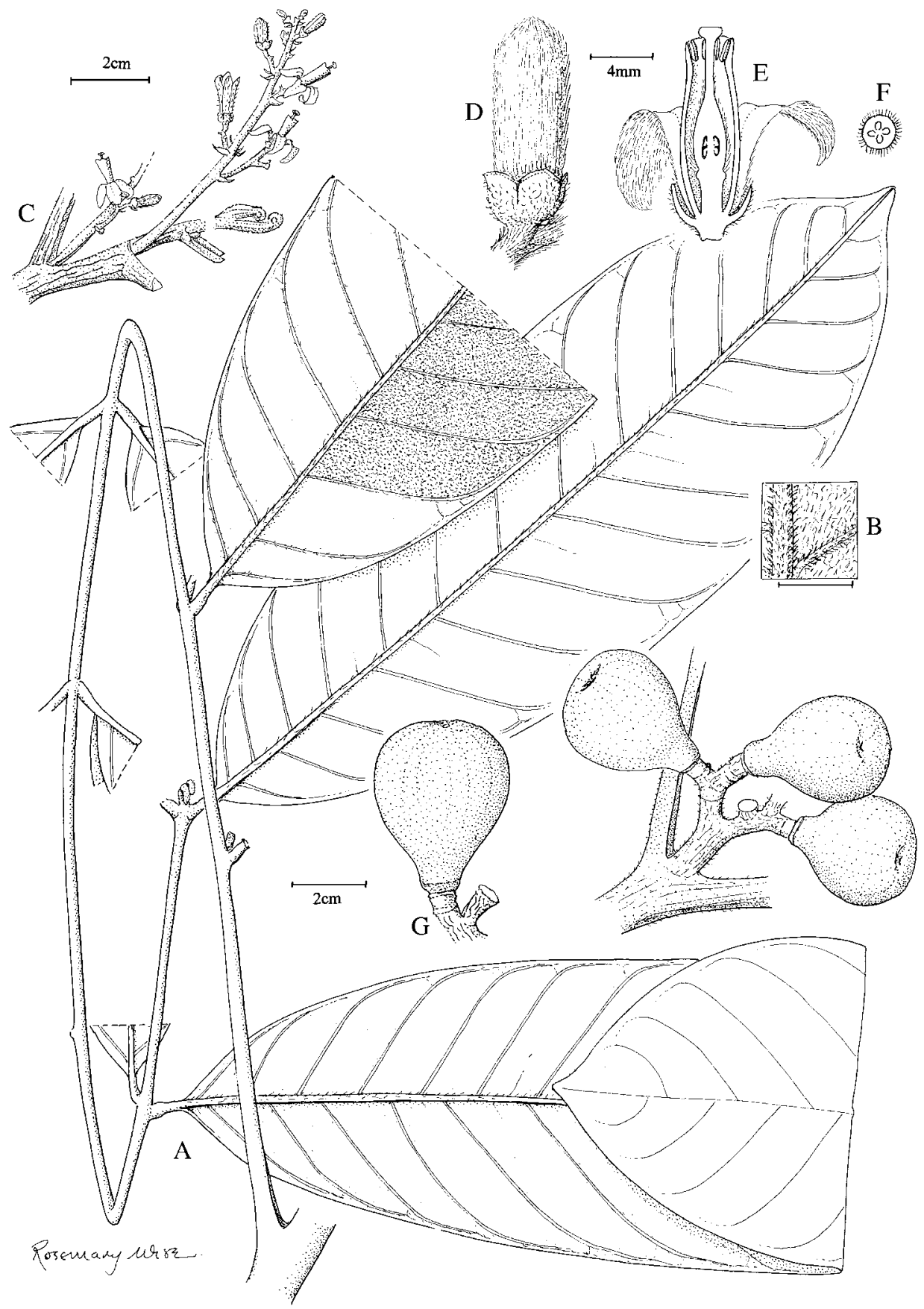

FIG. 47. Guarea trunciflora C.DC. A, habit; B, enlargement of leaf undersurface; C, inflorescence; D, flower bud; E, half-flower; F, cross-section of ovary; G, H, fruit. (A, B, G, H, Clarke, D. et al. 7719; C-F, Mori et al. 21325). 
Peru. Loreto: Requena, $3 \mathrm{~km}$ E of Jenaro Herrera (SW0473), Daly et al. 6222 (K); Rio Nanay, Caserio Mishana (SW0373), Foster et al. 4906 (F, K); Iquitos, Puerto Almendras (SW0373), Pennington \& Criollo 12413 (K); Requena, Quebrada de Curiyacu (SW0473), Rimachi 4322 (K); Rio Nanay, Puerto Almendras (SW0373), Vásquez \& Jaramillo 10974 (K), 13655 (MO, QCNE); Maynas, Mishana (SW0373), Vásquez et al. 4004 (K).

Brazil. Amazonas: Municipio Novo Airão, Waimiri Atroari area (SW0161), Milliken et al. 495 (K), 631 (K); Distrito Agropecuario, Reserve 1501 (km 41) (SW0259), Mori et al. 21325 (K); Manaus, Ducke Reserve (SW0259), Ribeiro et al. 1620 (K), Sothers \& Silva 411 (K), Sothers \& Pereira 426 (K).

69. Guarea venenata T.D.Penn. in T.D.Penn. et al., Fl. Neotrop. 28: 346, fig. 73 (1981). - Type: Colombia, Amazonas, Trapecio Amazónico, fl., Duque-Jaramillo 2375 (holo COL). Fig. 56E.

Abbreviated description. Young shoots and inflorescences coarsely pubescent or tomentose, leaves with an apical bud showing intermittent growth, leaflets 3-9 pairs, 19-32 × 5.4-7.7 cm, oblong or narrowly elliptic, rarely oblanceolate, chartaceous, glabrous above, sparsely and coarsely pubescent below on the veins, with minute red papillae on the lamina, venation brochidodromous, secondary veins 25-30 pairs, ascending, straight and parallel, inflorescence cauliflorous, 1-3 cm long, racemose, petals 4 , valvate, c. $12.5 \mathrm{~mm}$ long, densely appressed pubescent outside, staminal tube c. $8.5 \mathrm{~mm}$ long, c. $2 \mathrm{~mm}$ broad, anthers 8 , ovary 4-locular, locules with 2 superposed ovules, long-strigose, capsule unknown.

Distribution and ecology. Amazonian Colombia and extreme western Amazonian Brazil where it is an understorey treelet of lowland non-flooded rain forest. Not yet recorded from Peru but almost certainly to be found there. No post-1981 collections have been seen.

\section{Doubtful Species}

The following were treated as 'Doubtful Species' in the Flora Neotropica monograph (Pennington et al., 1981), and in the absence of further information on their relationships they remain dubious. See Pennington in Pennington et al. (1981: 357-359) for further discussion.

Guarea apiodora Baillon

Guarea longifoliola C.DC.

Guarea lophos Vell.

Guarea macrobotrys Poepp. \& Endl.

Guarea maynasiana C.DC.

Guarea sinuata Roemer

Guarea suberosa C.DC.

Guarea subsetulosa Harms 


\section{ACKNOWLEDGEMENTS}

The first author is grateful to the Director of the Royal Botanic Gardens, Kew and to the Keeper of the Herbarium, Library, Art \& Archives, for the use of the facilities of the herbarium and library during this study; to the Directors and staff of all the herbaria cited in the text, for their time spent processing the loans of herbarium specimens; and to the Leverhulme Trust for the award of an Emeritus Research Fellowship (2006-7) which enabled me to visit many overseas herbaria containing important Guarea collections, and to fund the mapping and the phylogenetic study. Special thanks are due to Justin Moat for the species mapping, to Mark Chase for facilitating the DNA sequencing in the Jodrell Laboratory, to Lourdes Rico for the list of exsiccatae and much other assistance, and to Rosemary Wise for the fine line drawings.

Fieldwork for this study was carried out in Peru, through the Department of Forest Management, National Agrarian University, La Molina, Lima, Peru, which has provided constant support over many years and the use of their field stations. Carlos Reynel and Aniceto Daza (MOL) have provided help over many years for the fieldwork in the Peruvian Amazon, so important for understanding these rainforest trees.

\section{REFERENCES}

BALDwin, B. G. (1992). Phylogenetic utility of the internal transcribed spacers of ribosomal DNA in plants: an example from the Compositae. Molec. Phylogenet. Evol. 1: 3-16.

Candolle, A. C. P. de (1878). In: Candolle, A. L. P. P. de \& Candolle, A. C. P. DE, Monographiae Phanerogamarum 1: 419-758.

Coronado, I. M. (2003). Systematic revision and multivariate analysis of the Guarea glabra Vahl (Meliaceae) complex from Mexico to Panama. Unpublished thesis for MSc degree, University of Missouri-Saint Louis.

Coronado, I. M. (2006). Five new species of Guarea (Meliaceae), two from the Guarea glabra Vahl complex, in Central America. Novon 16: 462-467.

Doyle, J. J. \& Doyle, J. L. (1987). A rapid DNA isolation procedure for small quantities of fresh leaf tissue. Phytochem. Bull. 19: 11-15.

Erkens, R. H. J., Chatrou, L. W., Maas, J. W., van der Niet, T. \& Savolainen, T. (2007). A rapid diversification of rainforest trees (Guatteria: Annonaceae) following dispersal from Central into South America. Molec. Phylogenet. Evol. 44: 399-411.

Felsenstein, J. (1985). Confidence limits on phylogenies: an approach using the bootstrap. Evolution 39: 783-791.

Fitch, W. M. (1971). Toward defining the course of evolution: minimum change for a specific tree topology. Syst. Zool. 20: 406-416.

Funuda, T., Yokoyama, J. \& Tsukaya, H. (2003). Phylogenetic relationships among species in the genera Chisocheton and Guarea that have unique indeterminate leaves as inferred from sequences of chloroplast DNA. Int. J. Plant Sci. 164: 13-24.

Gonzalez, M. A., Baraloto, C., Engel, J., Mori, S. A., Petronelli, P., Riera, B. ET AL. (2009). Identification of Amazonian trees with DNA barcodes. PLOS ONE 4, e7483.

GrAyum, M. H. (2006). The identity and typification of Guarea hoffmanniana C.DC. (Meliaceae). Taxon 55: 1005-1008.

Harms, H. (1940). In: Engler, A. \& Prantl, K., Die Naturlichen Pflanzenfamilien ed. 2, 19b1: 1-172. 
Huelsenbeck, J. P. \& Ronquist, F. (2001). MRBAYES: Bayesian inference of phylogenetic trees. Bioinformatics 17: 754-755.

Koenen, E. J. M. \& De Wilde, J. J. F. E. (2012). A taxonomic revision of the reinstated genus Leplaea and the newly recognized genus Neoguarea (Meliaceae: Sapindales). Plant Ecol. Evol. 145: 209-241.

McVaugh, R. (2000). Botanical results of the Sesse \& Mocino Expedition (1787-1803). 7. A guide to the relevant scientific names of plants. Carnegie Mellon University, Pittsburgh: Hunt Institute for Botanical Documentation.

Muellner, A. N., Samuel, R., Johnson, S. A., Cheek, M., Pennington, T. D. \& Chase, M. W. (2003). Molecular phylogenetics of Meliaceae based on nuclear and plastid DNA sequences. Amer. J. Bot. 90: 471-480.

Muellner, A. N., Samuel, R., Chase, M. W., Pannell, C. M. \& Greger, H. (2005). Aglaia (Meliaceae): an evaluation of taxonomic concepts based on DNA data and secondary metabolites. Amer. J. Bot. 92: 534-543.

Muellner, A. N., Savolainen, V., Samuel, R. \& Chase, M. W. (2006). The mahogany family 'out-of-Africa': divergence time estimation, global biogeographic patterns inferred from plastid rbcL DNA sequences, extant and fossil distribution of diversity. Molec. Phylogenet. Evol. 40: 236-250.

Muellner, A. N., Samuel, R., Chase, M. W., Coleman, A. \& Stuessy, T. F. (2008). An evaluation of the tribes and of generic relationships in Melioideae (Meliaceae) based on nuclear ITS ribosomal DNA. Taxon 57: 98-106.

Palacios, W. A. (1994). Espécies nuevas de Meliaceae del Ecuador y areas adyacentes. Novon 4: 155-164.

Palacios, W. A. (2007). Fam. 98 Meliaceae. Fl. Ecuador No. 82: 1-90.

Pennington, T. D. (1986). Meliaceae: a família do cedro na região cacaueíra da Bahía.

Boletim Técnico (CEPEC) 143: 1-64.

Pennington, T. D. (2006). Flora da Reserva Ducke, Brasil, Meliaceae. Rodriguesia 57(2): 209-246.

Pennington, T. D. \& Biggs, N. (in press). Meliaceae in Flora of the Guianas.

Pennington, T. D. \& Edwards, K. S. (2001). In: Berry, P. E., Holst, B. K. \& YAtSKievych, K. (eds) Flora of the Venezuelan Guayana 6: 528-549.

Pennington, T. D. \& Görts van Rijn, A. R. A. (1984). In: Stoffers, A. L. \& Lindeman, J. C. (eds) Flora of Suriname 5(1): 519-569.

Pennington, T. D. \& Mori, S. A. (1993). Guarea michel-moddei (Meliaceae), a new species from central French Guiana. Brittonia 45: 231, figs 1, 2.

Pennington, T. D. \& Styles, B. T. (1975). A generic monograph of the Meliaceae. Blumea 22: 419-540.

Pennington, T. D. \& Styles, B. T. (2001). In: Stevens, W. D., Ulloa, C., Pool, A. \& Montiel, O. M. (eds) Flora de Nicaragua 2 (Meliaceae): 1419-1430.

Pennington, T. D., Styles, B. T. \& Taylor, D. A. H. (1981). Meliaceae. Flora Neotropica 28: 1-470.

Richardion, J. E., Pennington, R. T., Pennington, T. D. \& Hollingsworth, P. M. (2001). Rapid diversification of a species-rich genus of Neotropical rainforest trees. Science 293: 2242-2245.

Rodriguez, A. (2006). Diez espécies nuevas de Guarea (Meliaceae) de Nicaragua, Costa Rica y Panamá. Lankesteriana 6(3): 101-121.

Salamin, N., Chase, M. W., Hodkinson, T. R. \& Savolainen, V. (2003). Assessing internal support with large phylogenetic DNA matrices. Molec. Phylogenet. Evol. 27: 528-539. 
Sasaki, D., Zappi, D., Milliken, W., Silva Henicka, G. da \& Piva, J. H. (2010). Vegetação e Plantas do Cristalino - um manual. Royal Botanic Gardens, Kew \& Fundação Ecológica Cristalino.

SwOFFord, D. L. (2001). PAUP* 4.0: Phylogenetic analysis using parsimony (*and other methods). Sunderland, MA: Sinauer Associates.

Received 13 October 2011; accepted for publication 15 January 2013

\section{MAPS}

A

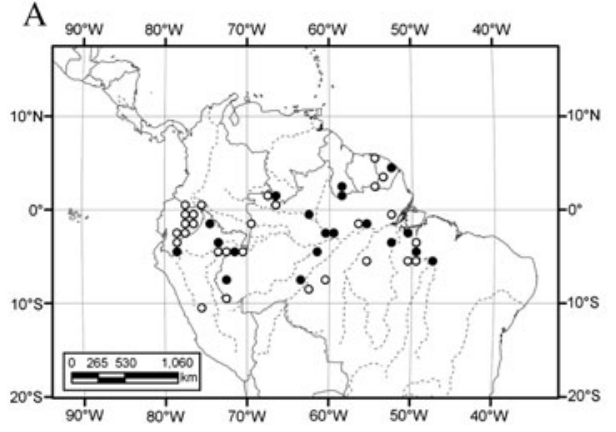

$\mathrm{C}$

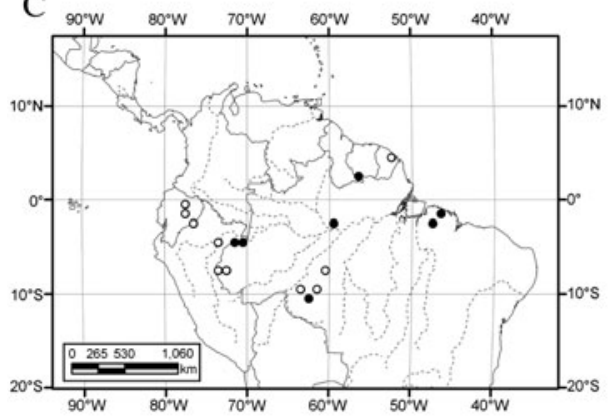

E

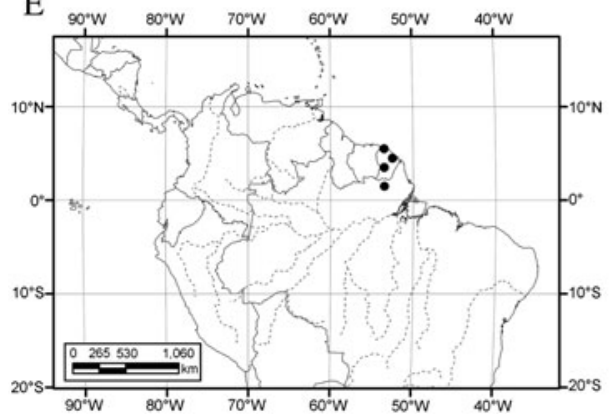

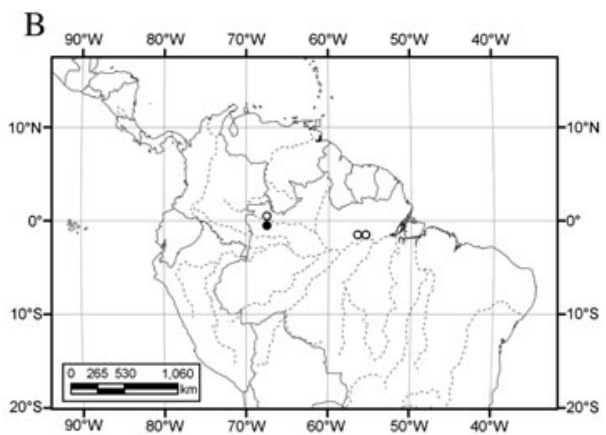

D
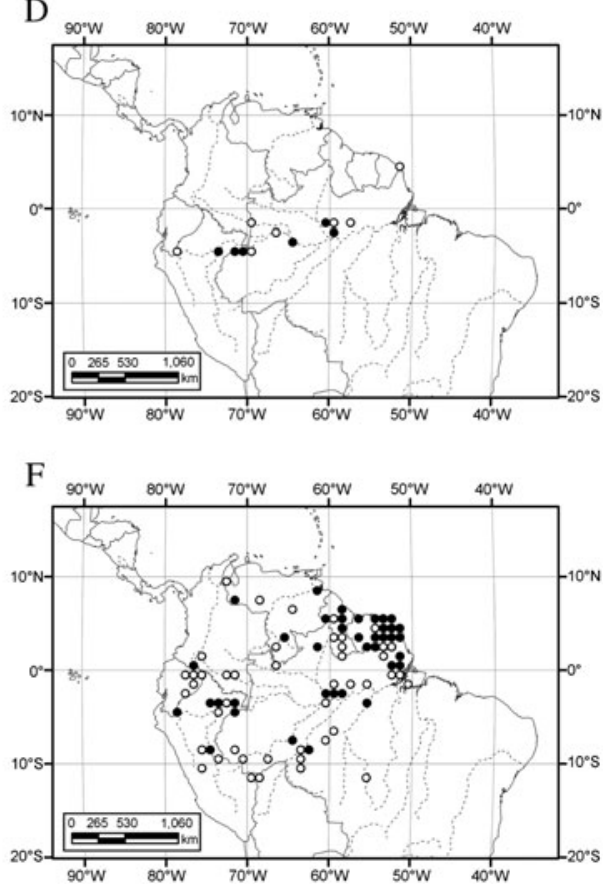

FIG. 48. Distribution of A, Guarea silvatica C.DC.; B, Guarea sprucei C.DC.; C, Guarea carinata Ducke; D, Guarea cinnamomea Harms; E, Guarea michel-moddei T.D.Penn. \& S.A.Mori; F, Guarea pubescens (Rich.) A.Juss. subsp. pubescens. (A-D, F: Solid dots, distribution pre-1981, open dots new records 1981-2010. E: Total distribution to 2010). 

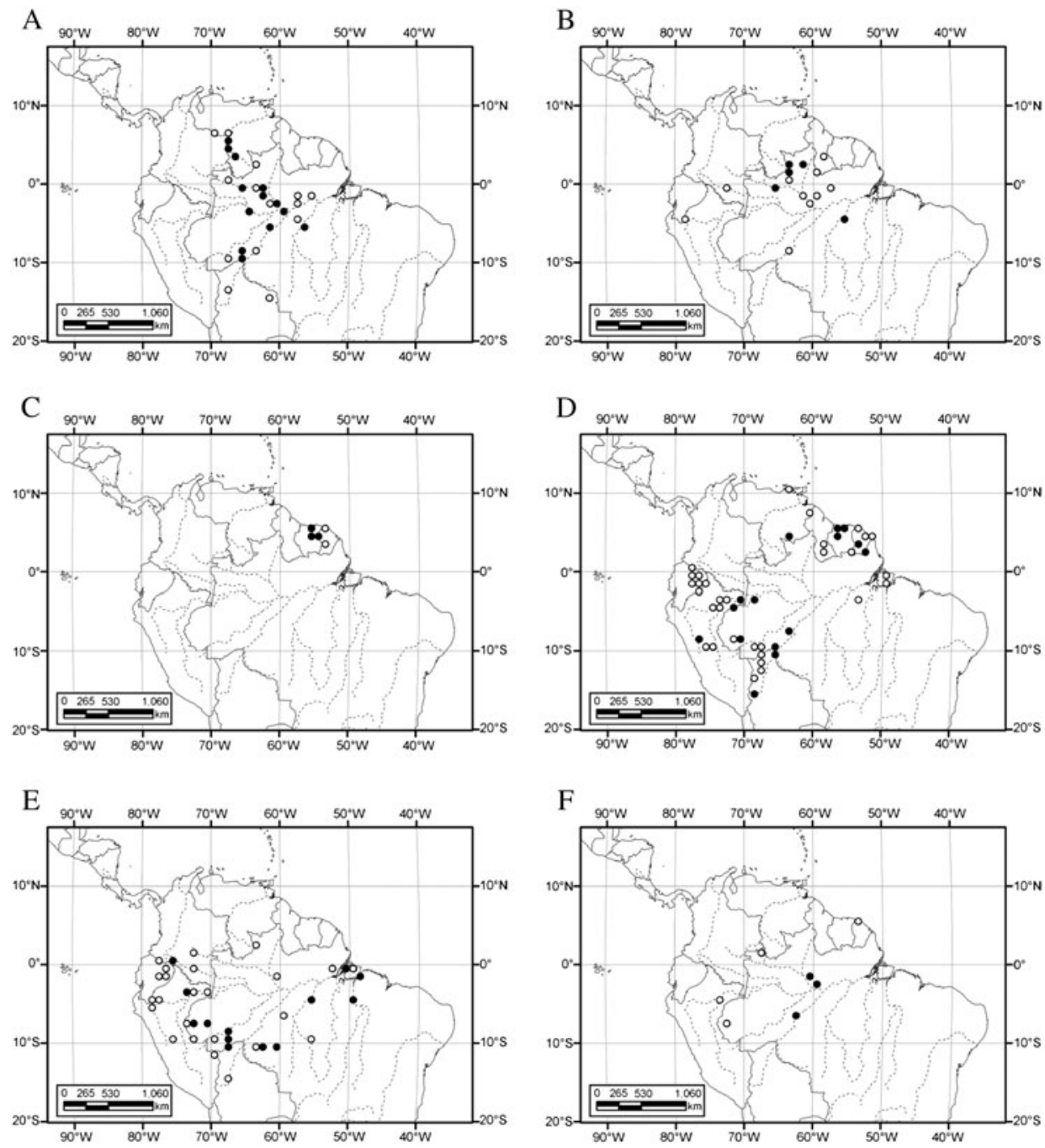

FIG. 49. Distribution of A, Guarea pubescens (Rich.) A.Juss. subsp. pubiflora (A.Juss.) T.D.Penn.; B, Guarea velutina A.Juss.; C, Guarea costata A.Juss.; D, Guarea gomma Pulle; E, Guarea purusana C.DC.; F, Guarea convergens T.D.Penn. (A-F: Solid dots, distribution pre-1981, open dots new records 1981-2010). 

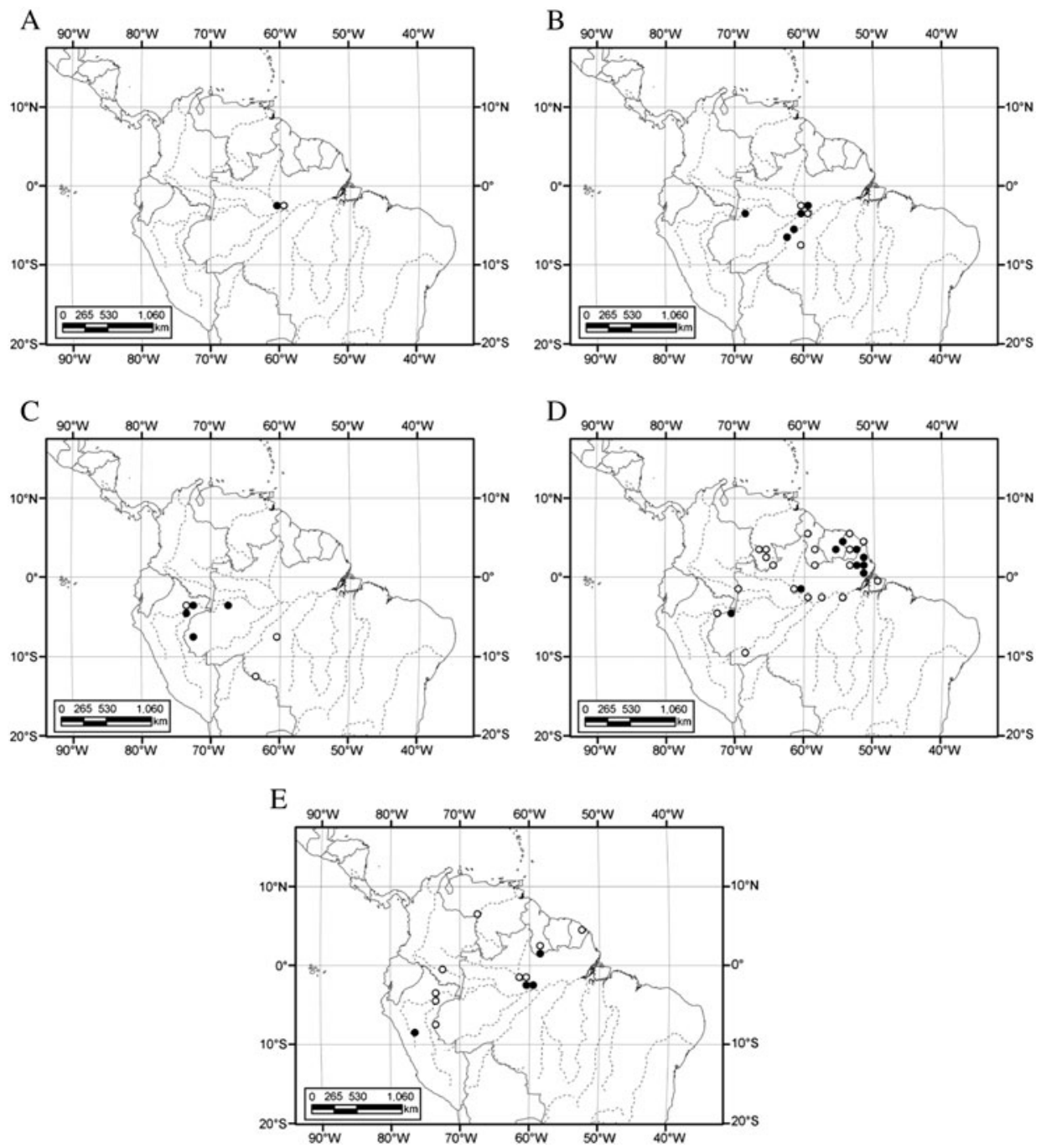

FIG. 50. Distribution of A, Guarea crispa T.D.Penn.; B, Guarea humaitensis T.D.Penn.; C, Guarea juglandiformis T.D.Penn.; D, Guarea scabra A.Juss.; E, Guarea trunciflora C.DC. (A-E: Solid dots, distribution pre-1981, open dots new records 1981-2010). 

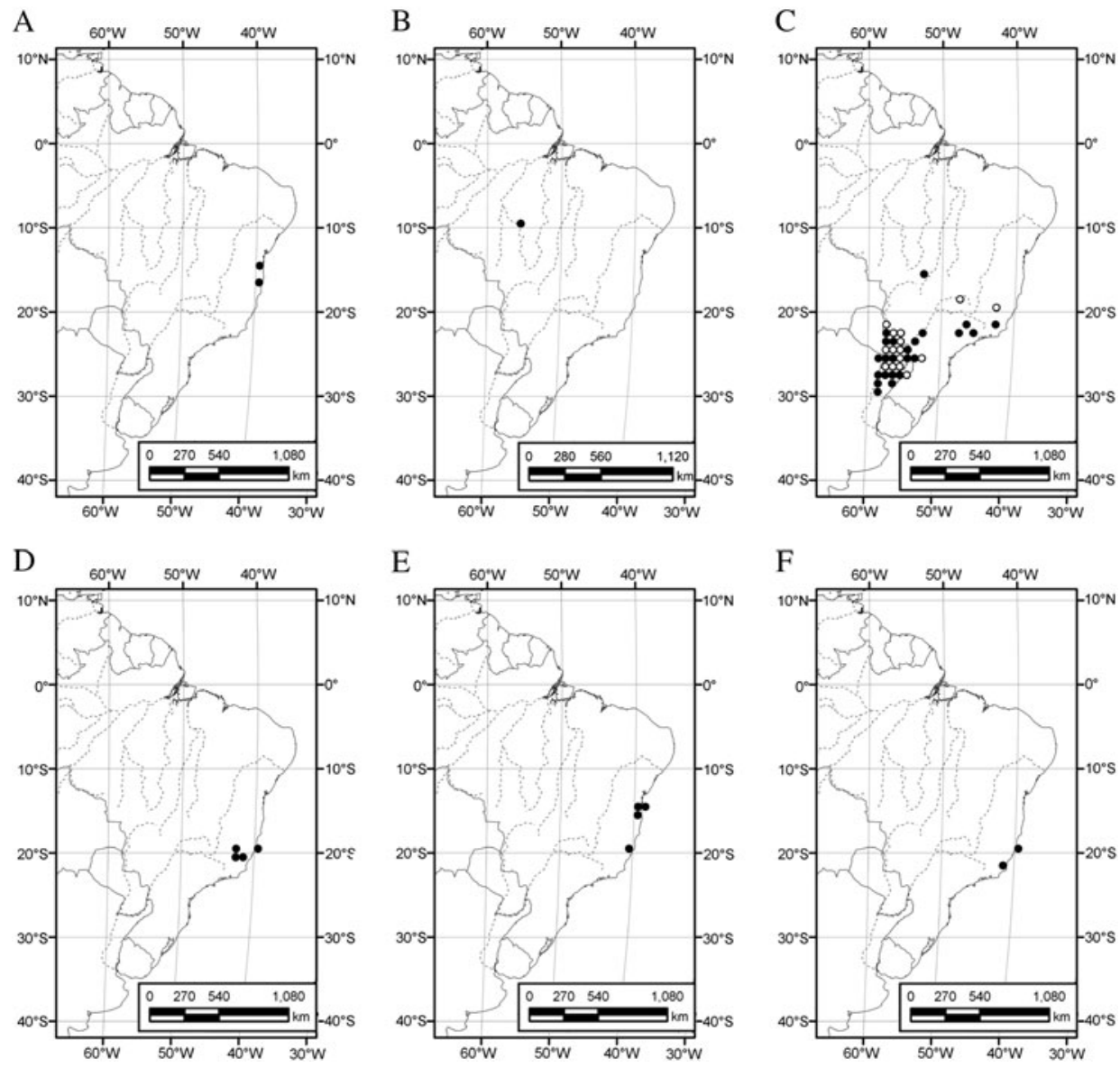

FIG. 51. Distribution of A, Guarea anomala T.D.Penn.; B, Guarea zepivae T.D.Penn.; C, Guarea macrophylla Vahl subsp. spiciflora (A.Juss.) T.D.Penn.; D, Guarea pendula R.S.Ramalho et al.; E, Guarea blanchetii C.DC.; F, Guarea gracilis T.D.Penn. (A, B, D-F: Total distribution to 2010. C: Solid dots, distribution pre-1981, open dots new records 1981-2010). 

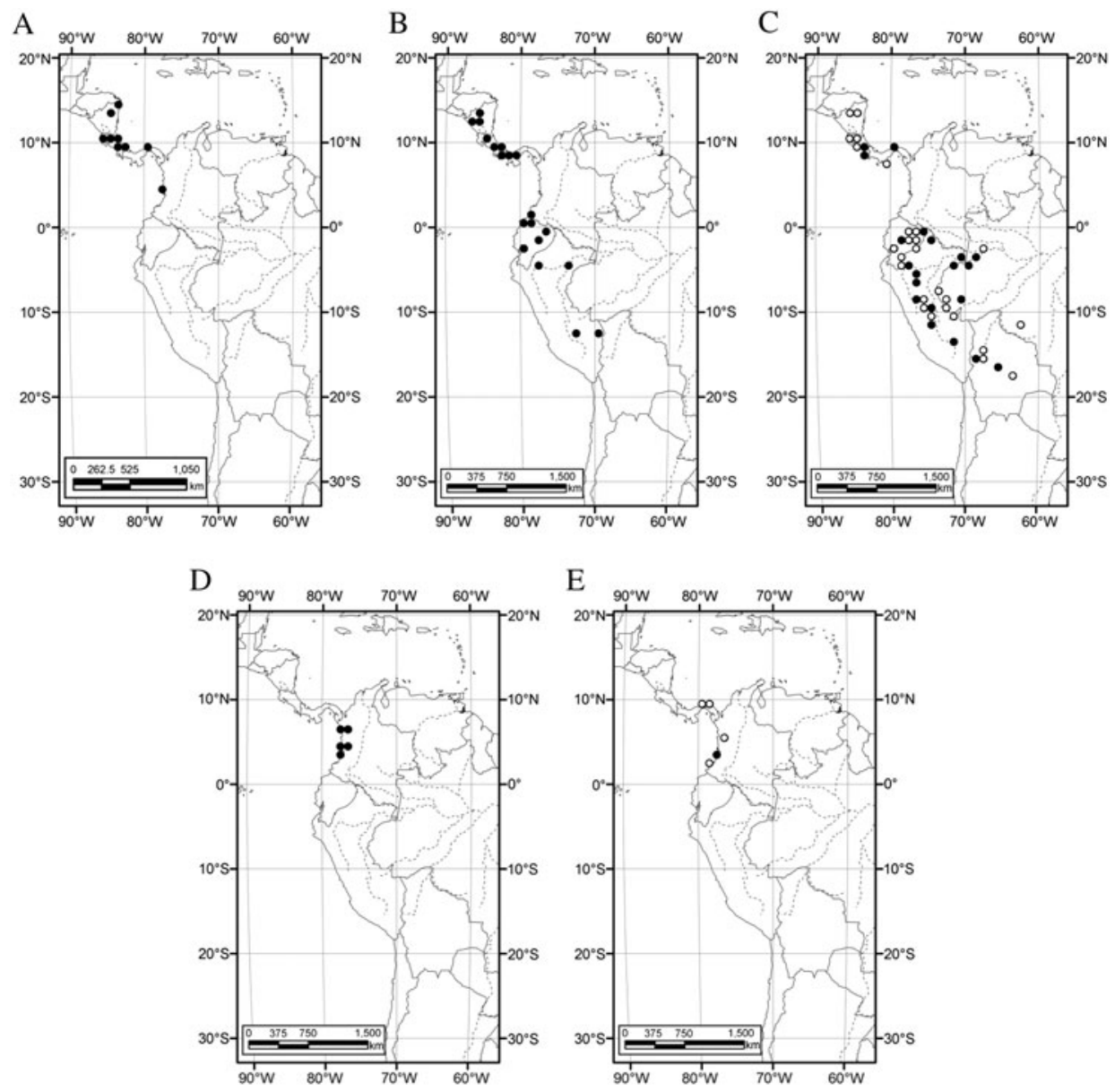

FIG. 52. Distribution of A, Guarea gentryi Coronado; B, Guarea glabra Vahl subsp. microcarpa (C.DC.) T.D.Penn.; C, Guarea pterorhachis Harms subsp. pterorhachis; D, Guarea pterorhachis Harms subsp. submarginalis T.D.Penn.; E, Guarea caulobotrys Cuatrec. (A, B, D: Total distribution to 2010. C, E: Solid dots, distribution pre-1981, open dots new records 1981-2010). 

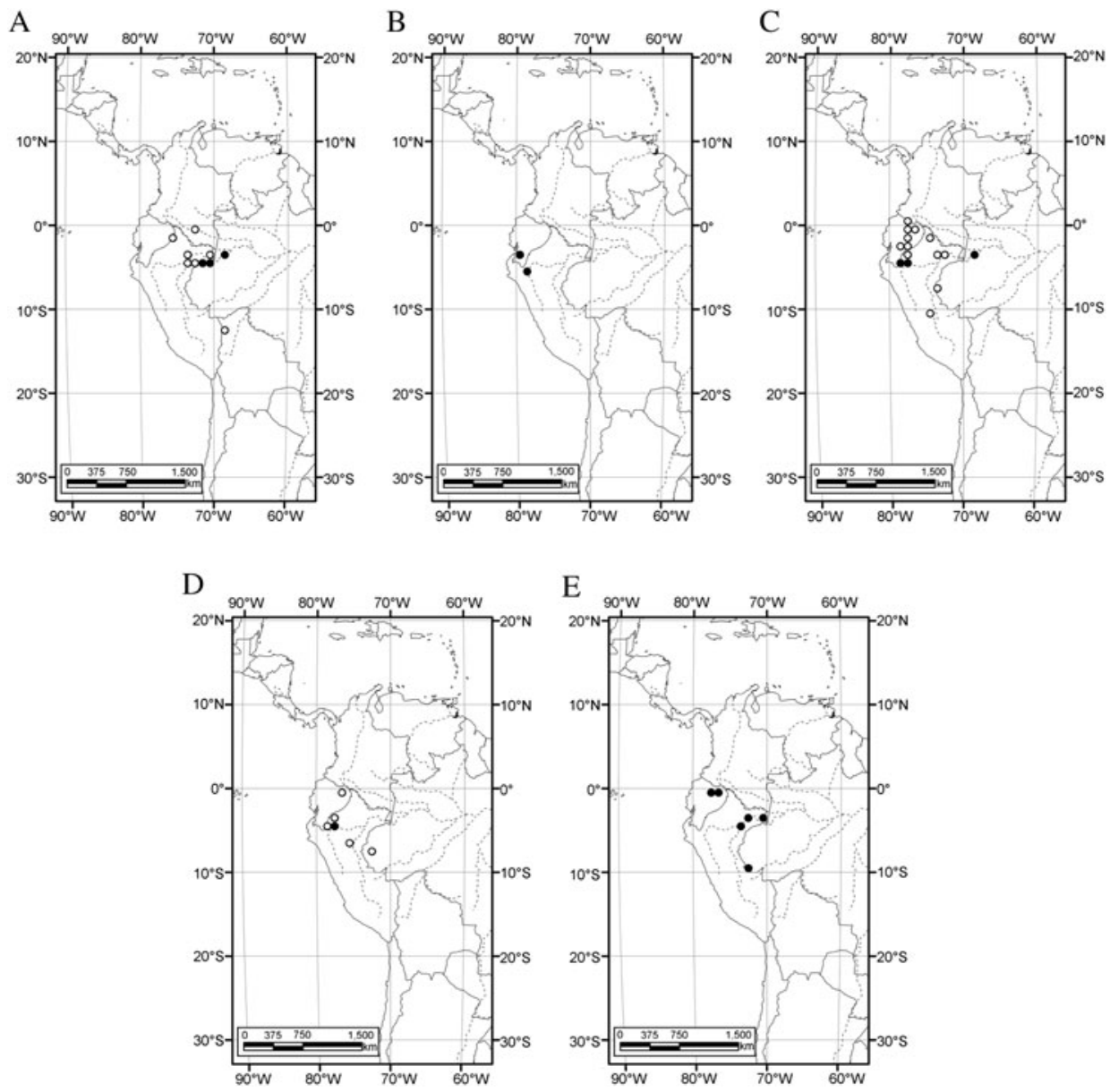

FIG. 53. Distribution of A, Guarea cristata T.D.Penn.; B, Guarea subandina W.Palacios; C, Guarea guentheri Harms; D, Guarea carapoides Harms; E, Guarea ecuadoriensis W.Palacios. (A, C, D: Solid dots, distribution pre-1981, open dots new records 1981-2010. B, E: Total distribution to 2010). 

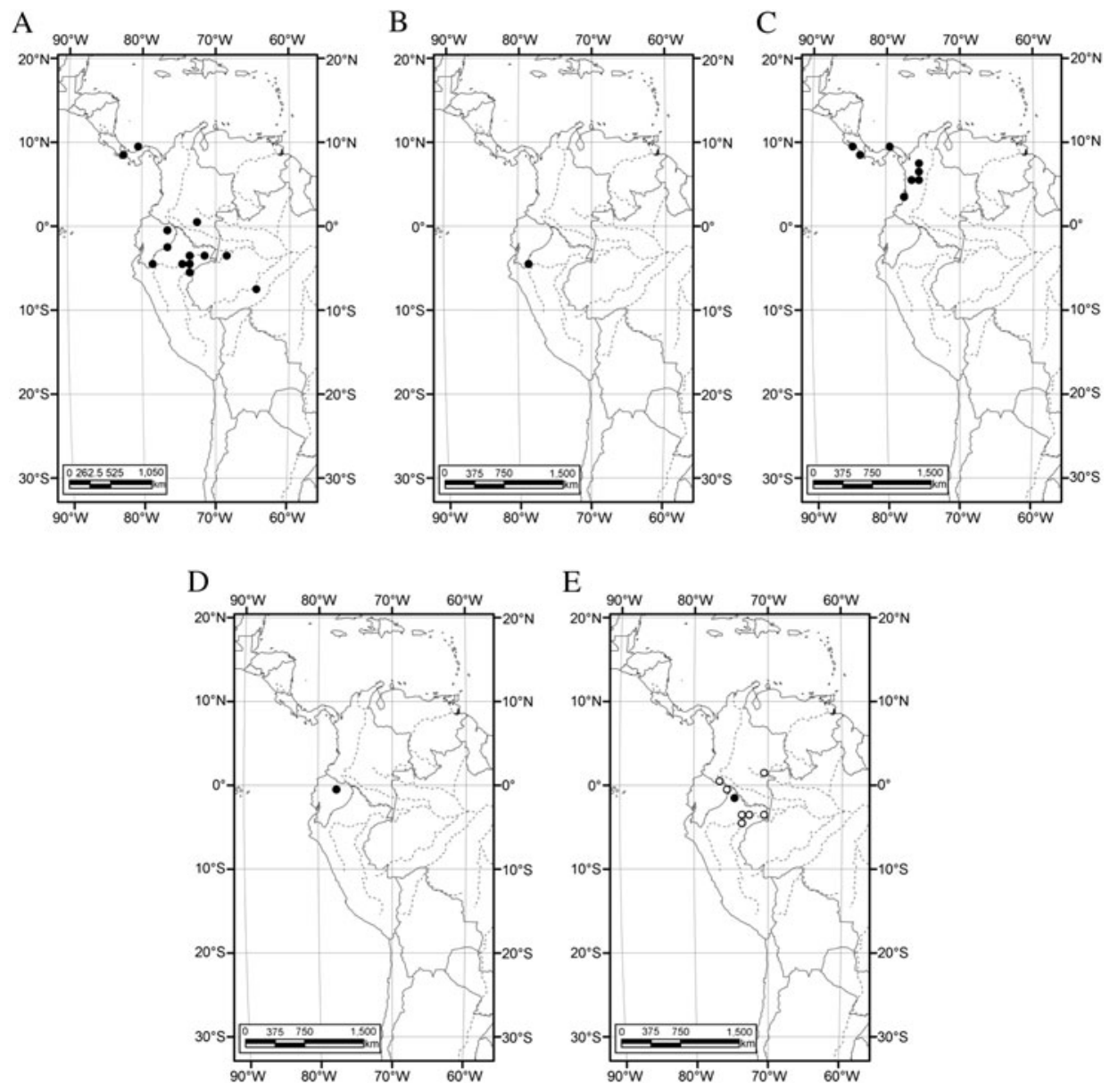

FIg. 54. Distribution of A, Guarea fistulosa W.Palacios; B, Guarea riparia W.Palacios; C, Guarea pyriformis T.D.Penn.; D, Guarea persistens W.Palacios; E, Guarea fissicalyx Harms. (A-D: Total distribution to 2010. E: Solid dots, distribution pre-1981, open dots new records 1981-2010). 

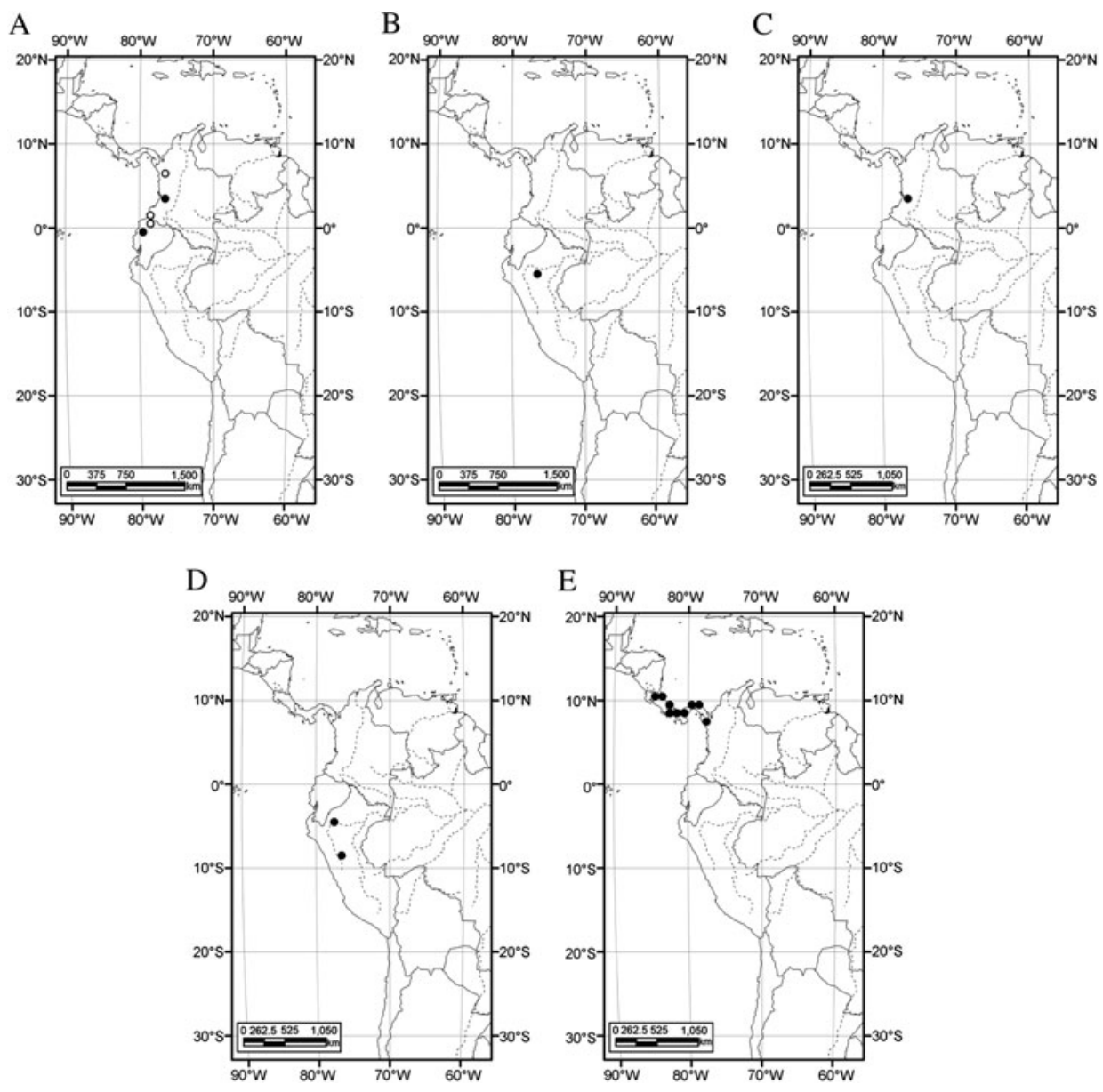

FIG. 55. Distribution of A, Guarea cartaguenya Cuatrec.; B, Guarea casimiriana Harms; C, Guarea corrugata Cuatrec.; D, Guarea eriorhachis Harms; E, Guarea hoffmanniana C.DC. (A: Solid dots, distribution pre-1981, open dots new records 1981-2010. B-E: Total distribution to 2010). 

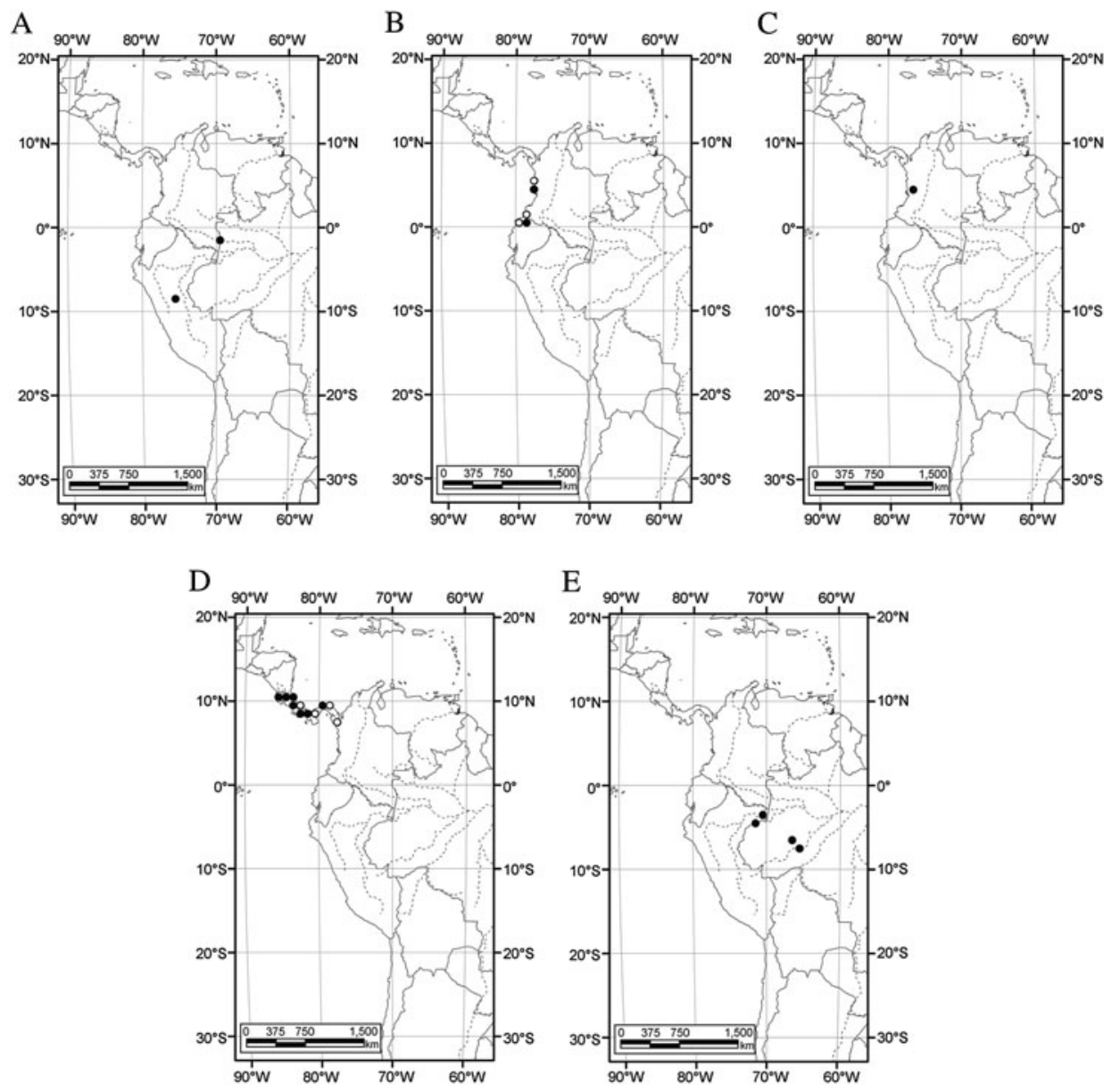

FIG. 56. Distribution of A, Guarea lozanii M.E.Morales; B, Guarea polymera Little; C, Guarea reticulatovenosa T.D.Penn.; D, Guarea rhopalocarpa Radlk.; E, Guarea venenata T.D.Penn. (A, C, E: Total distribution to 2010. B, D: Solid dots, distribution pre-1981, open dots new records 1981-2010). 

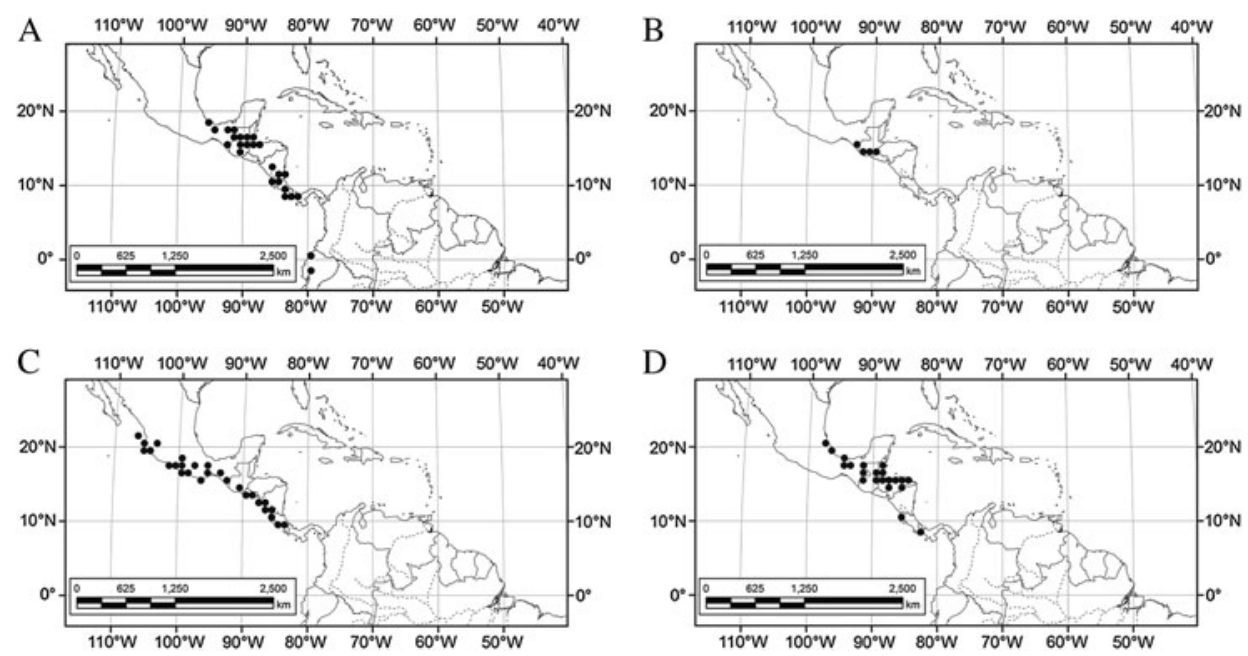

FIG. 57. Distribution of A, Guarea bijuga C.DC.; B, Guarea luxii C.DC.; C, Guarea glabra Vahl subsp. excelsa (Kunth) T.D.Penn.; D, Guarea glabra Vahl subsp. tuerckheimii (C.DC.) T.D.Penn. (A-D: Total distribution to 2010).
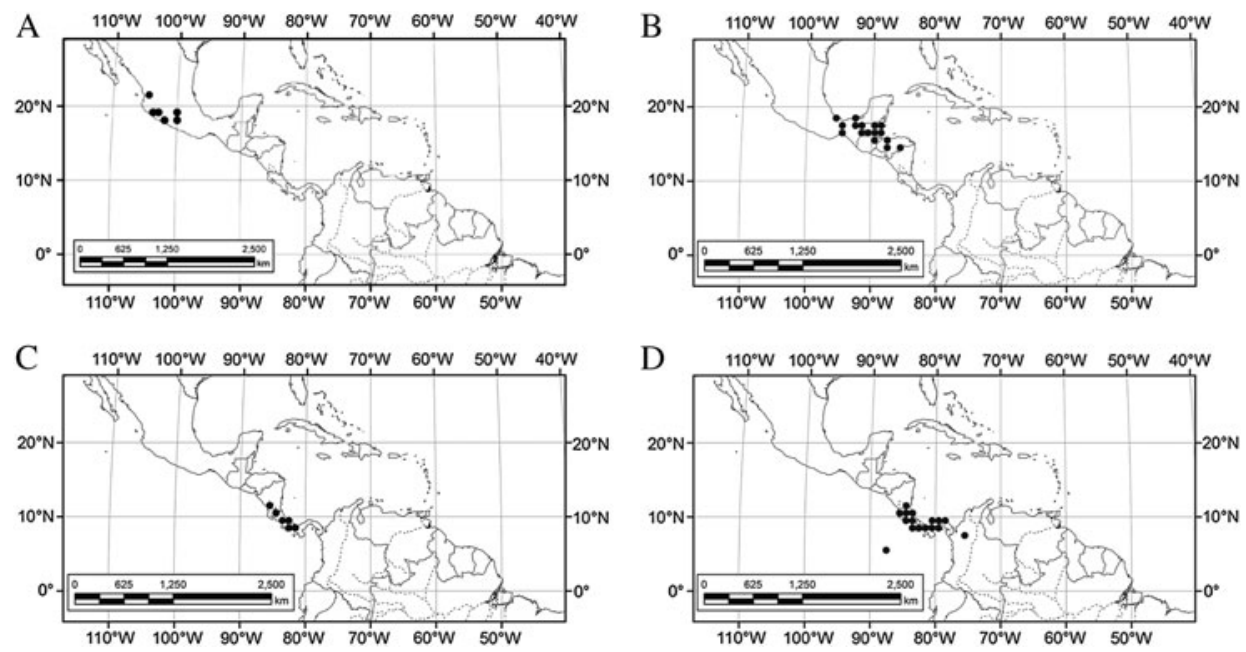

FIG. 58. Distribution of A, Guarea glabra Vahl subsp. glabrescens (Hook. \& Arn.) T.D.Penn.; B, Guarea glabra Vahl subsp. rovirosae (C.DC.) T.D.Penn.; C, Guarea tonduzii C.DC.; D, Guarea chiricana Standl. (A-D: Total distribution to 2010). 

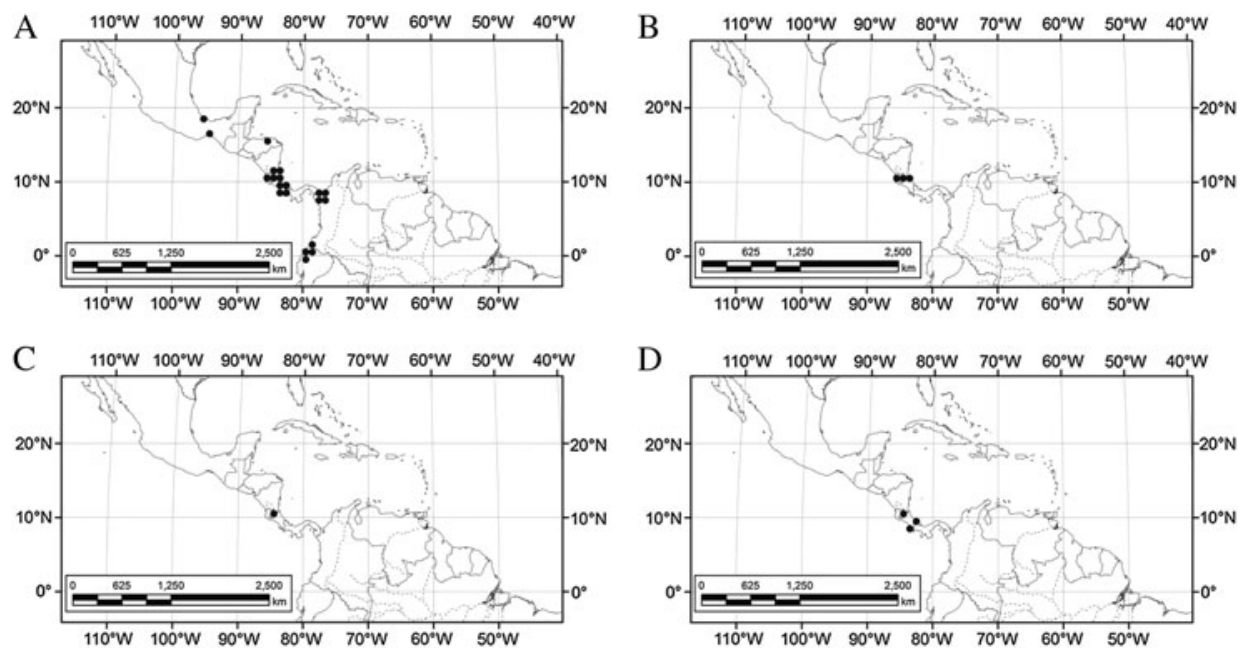

FIG. 59. Distribution of A, Guarea bullata Radlk.; B, Guarea zarceroensis Coronado; C, Guarea tafae-malekui Al.Rodr.; D, Guarea macrocalyx Al.Rodr. (A-D: Total distribution to 2010).
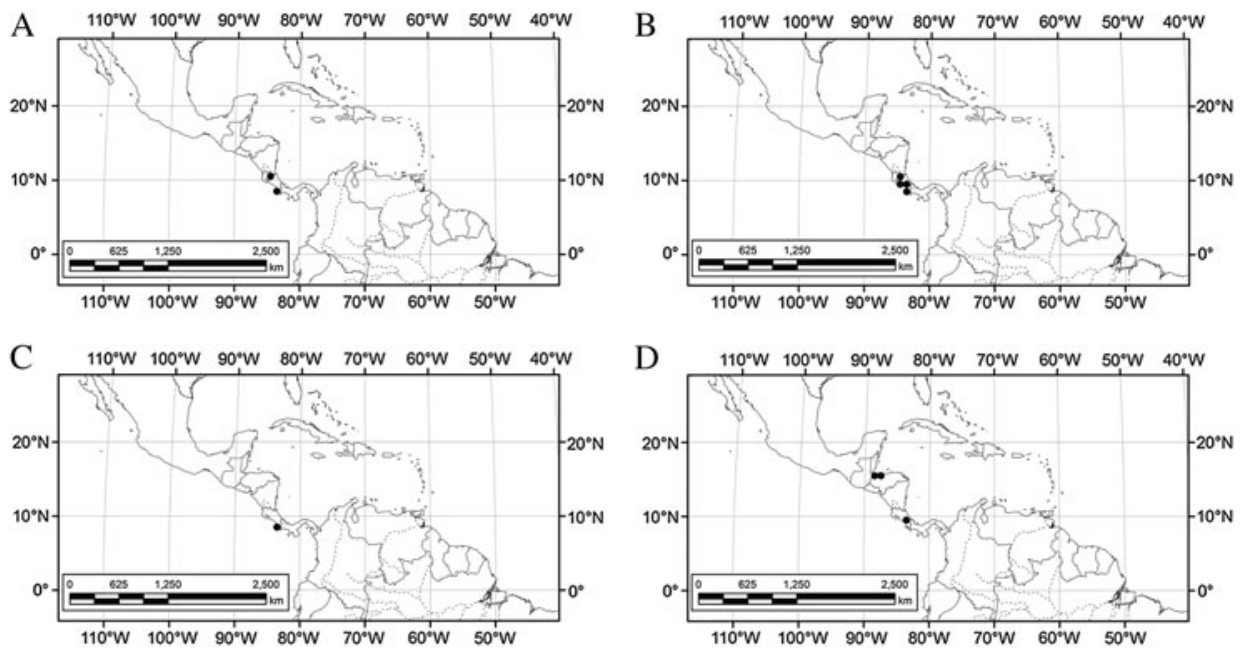

FIG. 60. Distribution of A, Guarea aguilarii Al.Rodr.; B, Guarea constricta Al.Rodr.; C, Guarea corticosa Al.Rodr.; D, Guarea donnell-smithii C.DC. (A-D: Total distribution to 2010). 

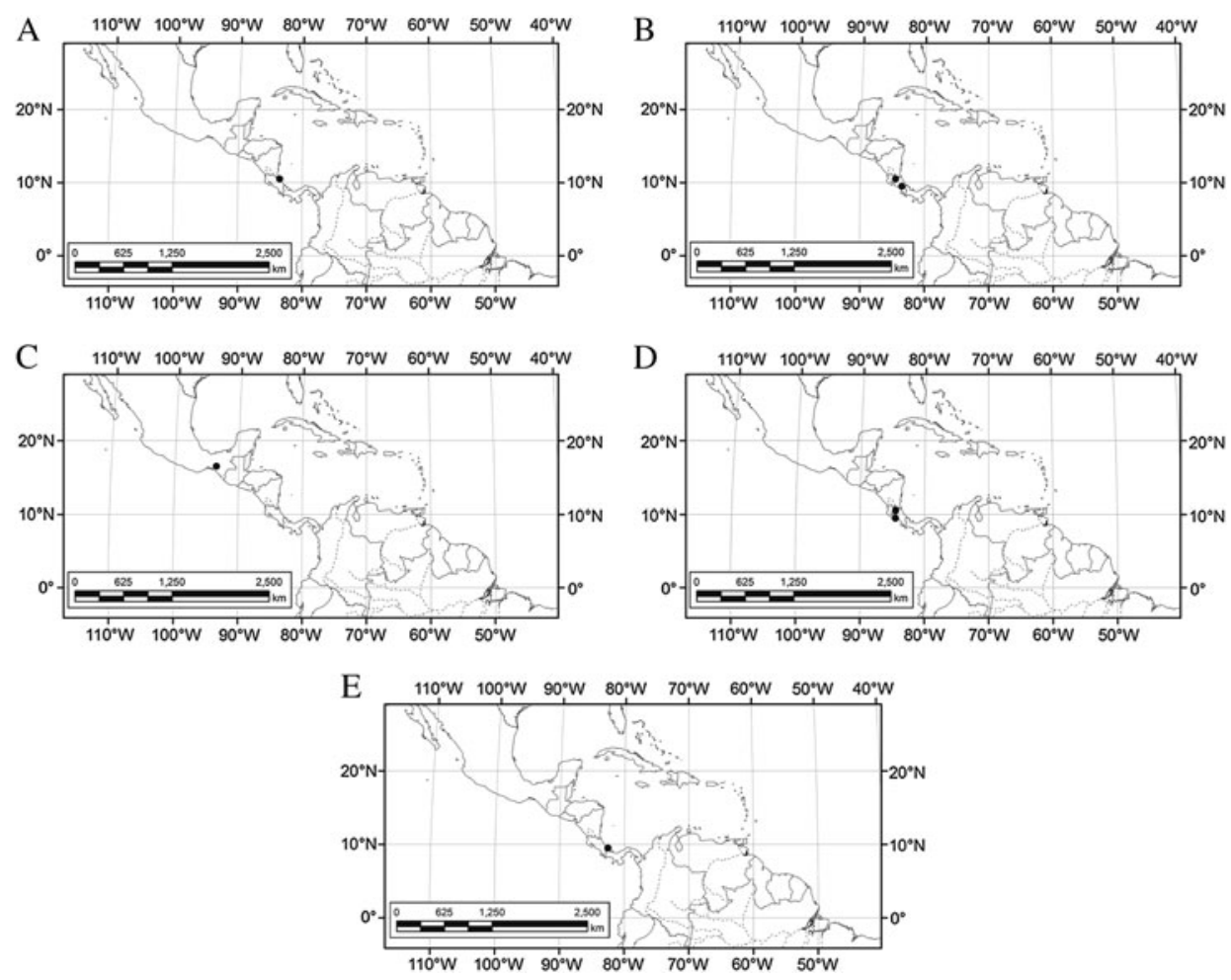

FIg. 61. Distribution of A, Guarea grossa T.D.Penn.; B, Guarea inesiana Al.Rodr.; C, Guarea mexicana Coronado; D, Guarea subsessilifolia Al.Rodr.; E, Guarea talamancana Gómez-Laur. \& M.Valerio. (A-E: Total distribution to 2010).

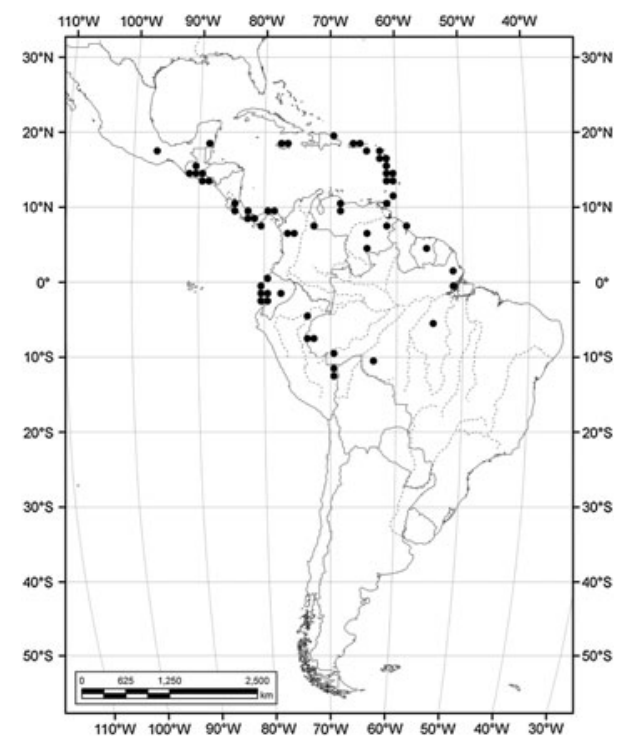

FIG. 62. Distribution of Guarea glabra Vahl subsp. glabra. Total distribution to 2010. 

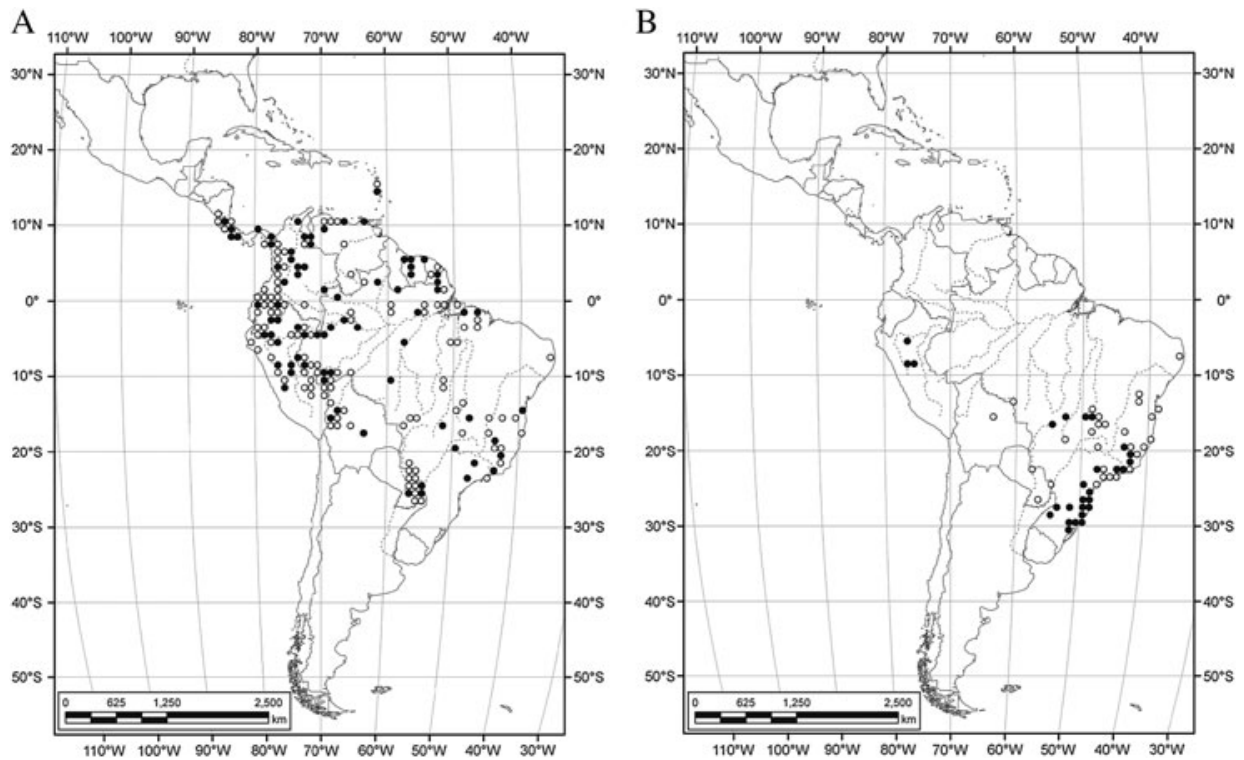

FIG. 63. Distribution of A, Guarea kunthiana A.Juss.; B, Guarea macrophylla Vahl subsp. tuberculata (Vell.) T.D.Penn. (A, B: Solid dots, distribution pre-1981, open dots new records 1981-2010).
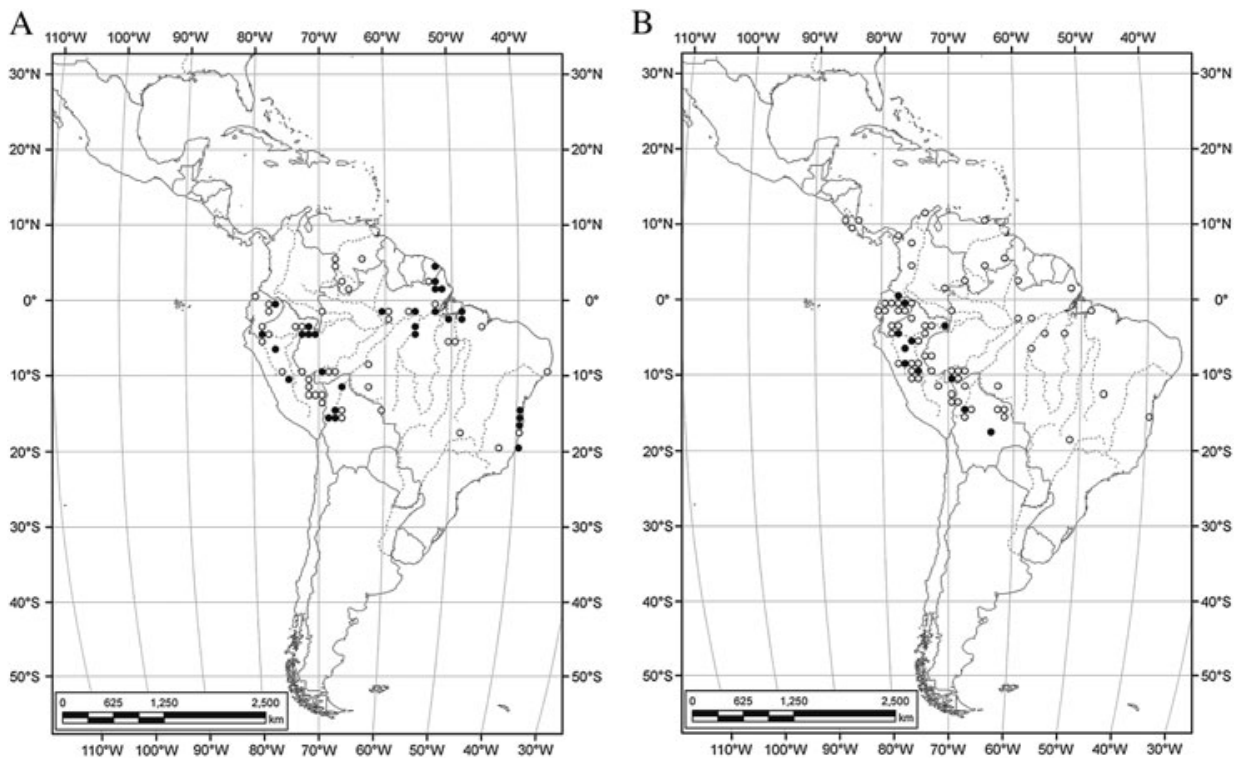

FIG. 64. Distribution of A, Guarea macrophylla Vahl subsp. pachycarpa (C.DC.) T.D.Penn.; B, Guarea macrophylla Vahl subsp. pendulispica (C.DC.) T.D.Penn. (A, B: Solid dots, distribution pre-1981, open dots new records 1981-2010). 

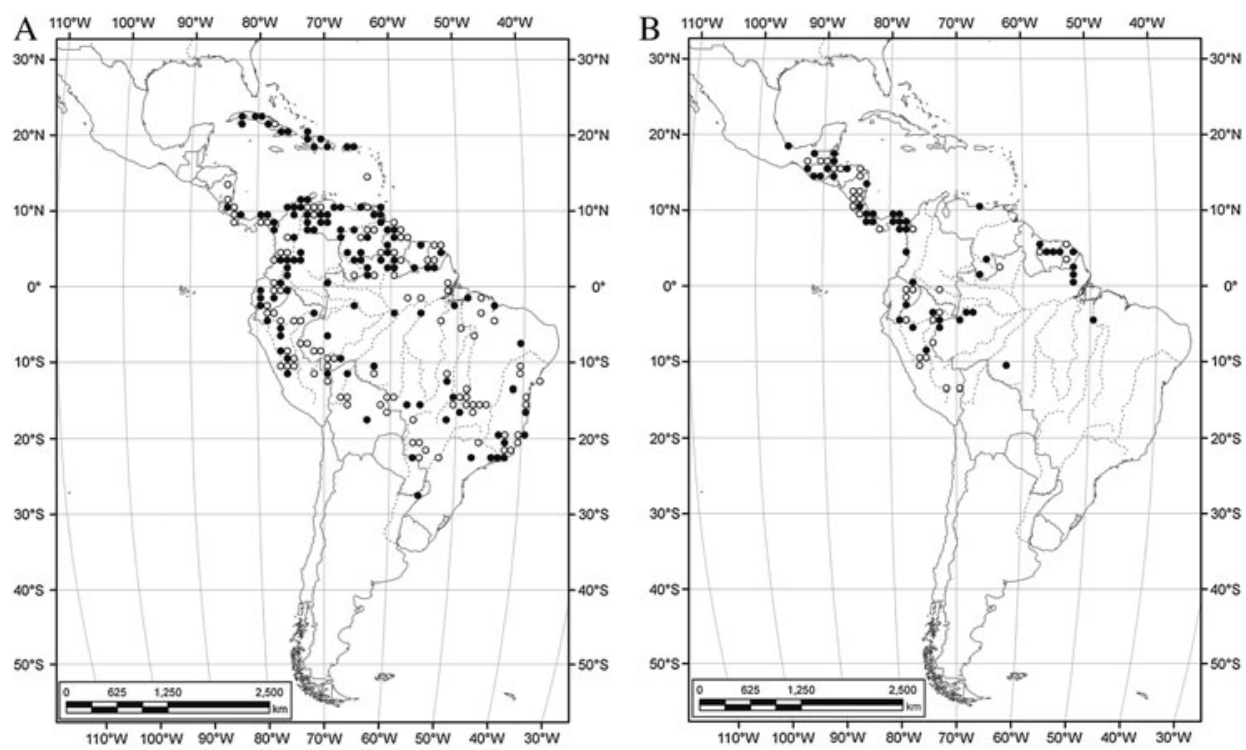

FIG. 65. Distribution of A, Guarea guidonia (L.) Sleumer; B, Guarea grandifolia DC. (A, B: Solid dots, distribution pre-1981, open dots new records 1981-2010).
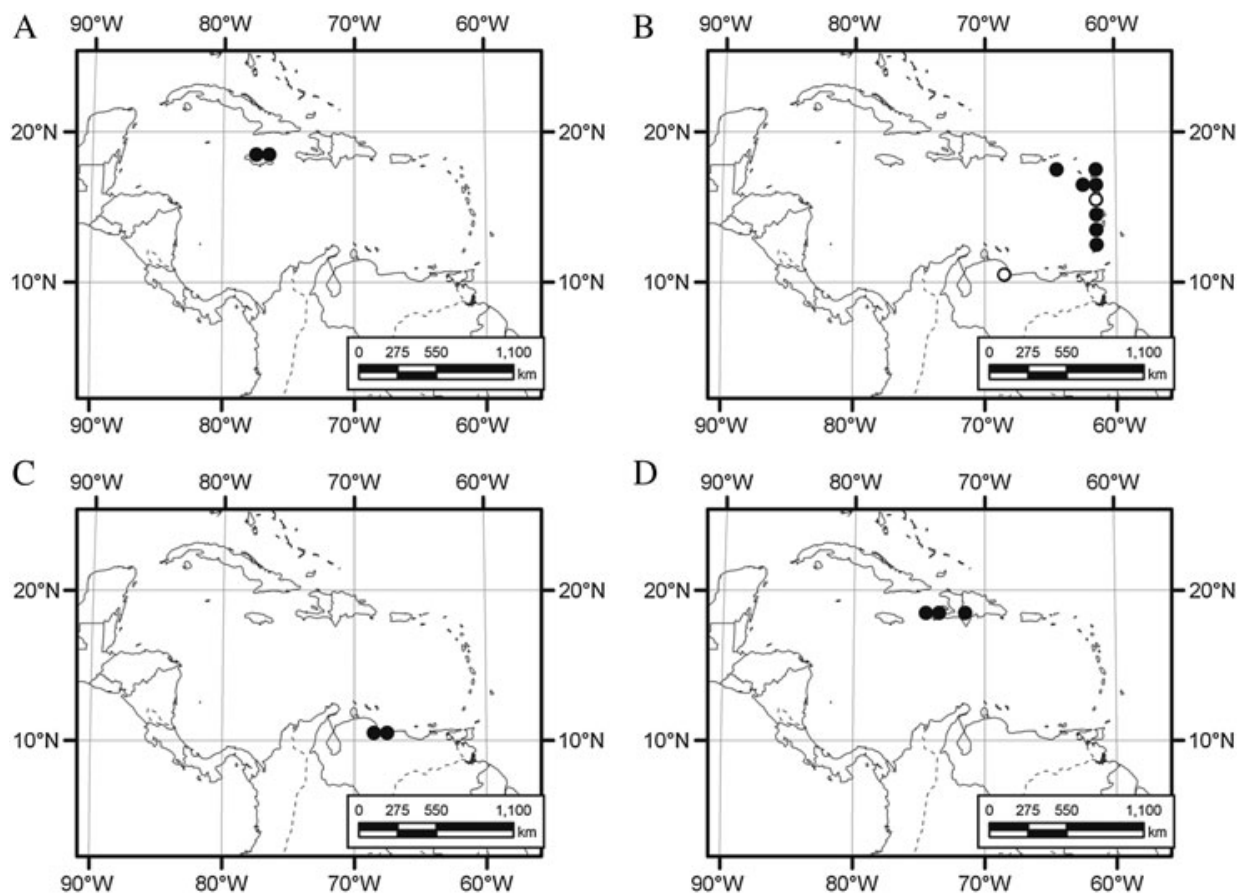

FIG. 66. Distribution of A, Guarea jamaicensis Proctor; B, Guarea macrophylla Vahl subsp. macrophylla; C, Guarea megacostata T.D.Penn.; D, Guarea sphenophylla Urb. (A, C, D: Total distribution to 2010. B: Solid dots, distribution pre-1981, open dots new records 1981-2010). 


\section{List OF EXSICCATAE}

The List of Exsiccatae contains all collections made after 1980, including specimens not cited in the text above, plus a few earlier ones mentioned in the text, such as types.

Acevedo D et al. 150 (3); Acevedo-Rodríguez \& Cedeño 7292, 7359 (1), 7475 (28a); AcevedoRodríguez \& Chinea 2195 (6a); Acevedo-Rodríguez et al. 150 (3), 150 (3), 1621 (34), 1706 (6c), 4978 (21a), 5678 (21a), 5753 (64), 5817 (40), 5836 (64), 5887 (21a), 5913 (40), 5986 (1), 6045 (37), 6090 (64), 7967 (21b), 8401 (21b), 9096 (10), 9654 (6a); Acosta et al. 1206 (8), 2030 (9); Agostini G \& T 1629 (40); Aguayo 27, 51, 153, 166, 264, 284, 359, 361 (28c), 475 (10), 570, 574 (28c); Aguilar 312 (49), 476 (43), 488 (49), 708 (9), 790 (24), 1190 (6b), 1861 (12a), 2650 (sp.), 3083, 3437 (10), 6287 (8); Aguilar \& Gilbert 3486 (8); Aguilar \& Hammel 35 (3); Aguilar et al. 1985 (9), 2259 (4), 4172 (9); Aguirre-Galviz 922 (34?); Aitken 18197 (6a); Alexander s.n. (6a); Alexiades \& Byrne 867 (28e), 870 (28d); Alexiades et al. 1021 (10), 184 (28a), 450 (28e); Alfaro 113 (4?), 4137 (6c); Alfaro \& Monro 5537 (7); Alfaro et al. 57 (63), 63 (4); Allen 3376 (10), 5377, 5501 (36), 5804 (42), 5951 (12a); Aluisio 50 (47), 200 (64), 221 (68); Alvarado 22 (sp.), 22 (4?), 286 (10), 302 (1), 38 (38); Alvarado et al. 795 (6b); Alvarengo \& Perdigão 935 (40); Alvarengo et al. 1273 (28e); Alvarez et al. 388 (42), 510 (10), 670 (42), 784 (68), 970 (10), 1866 (38), 2809 (58), 2809 (20); Amaral 1485, 1490 (40); Amaral et al. 1365 (1), 149 (21b), 304 (10), 463 (28e), 505 (64), 513 (1), 524 (28e); Amorin et al. 1279 (40); Ancuash 1508 (40), 20 (27), 30 (28d); Andel van et al. 10 (69?); Anderson 25 (40); Anderson \& Sternberg 3471 (6a); Anderson et al. 1159, 1200 (40); Andrle \& Axtell 9 (4); Angulo 139 (6c), 305 (sp.); Angulo et al. 45 (4?); Aranda et al. 67 (42), 3238 (6c); Araquistain 3135 (9), 3186 (40), 3769, 3795, 3802, 3817 (6b); Araujo $1480 A$ (28b), 2063, 3381, 4309 (40); Araujo et al. 1056 (40), 1110, 4113 (28b); Araya 358 (8), 39 (40), 763 (10); Araya et al. 263 (9); Arbo et al. 5597, 7827 (40); Arevalo 520 (sp.); Aristeguieta 3182 (6a?); Aristeguieta \& Foldats 1369 (40); Aristeguieta \& Huber 318 (10); Aristeguieta \& Zabala 6928 (40), 7078 (40); Arnason \& Lambert 17033 (6f); Asplund 18762 (12a); Assis et al. 1071 (28b); Assunção \& Vicentini 1 (55); Assunção et al. 328 (1), 809 (55); Aulestia C 942 (61); Aulestia C et al. 305 (44), 374 (44), 583 (44?); Aulestia M 2714 (10); Aulestia M \& Bainca 3472 (12a); Aulestia M \& Gonti 1976 (6c); Aulestia M \& Grefa 185 (32); Aulestia M \& Omehuai 3331 (1); Aulestia M \& Quihuinamo 3197 (21a); Aulestia M et al. 1144 (12a), 3609 (12a); Austin \& Cavalcante 4092 (28d), 4149 (39); Avidel van et al. 2668 (40); Axelrod 9001 (40); Ayala 1690 (57); Ayala \& Arevalo 4299 (10); Ayala et al. 2515 (34); Aymard \& Delgado 8075 (28d); Aymard et al. 6917 (28e), 9730 (28d); Azevedo \& Neto 249 (28b).

Bagazo 188 (28e); Baker 11 (6b), 5904 (10), 5917 (37); Baker et al. 5944, 5951 (10), 5995, 6065, 6117 (42); Balée 1066 (28d), 3328 (40), 3404 (10); Balée \& Ribeiro 1598 (40), 2742, 2796, 2848, 2892, 2923 (10), 293, 431 (40), 98 (28e); Balick et al. 2059 (6f), 2482 (4); Ballestero (49); Balslev \& Irvine 4627 (28e); Balslev et al. 84692 (1), 84780 (41); Bamps 5379 (10); Bang 1373 (40), s.n. (28d); Barbosa et al. 8090 (34); Barker \& Thompson 13 (28d); Barretto 13007 (40), 1386 (28b), 1440, 6334 (40), 9959 (10); Barrier 3375 (6a); Barros 1962 (28b); Bartlett 12210 (6f), 12321 (6f); Bartlett \& Lasser 6635, 16997 (6a); Bass 357 (21a); Basualdo 1502, 1770 (28c), 1818 (10); Basualdo et al. 1412 (10); Beard J 229 (28a), 410, 463 (6a); Beard P 1165 (6a); Beck 6647 (40), 6886, 7335 (10), 7347 (5e?), 8128 (28e), 8292 (40), 9317 (10), 12244, 12740 (40), 18442 (28e); Beck \& Haase 10162 (21b); Beck \& Seidel 16731 (28e); Beck et al. 46 (1), 266 (39), 16442 (10), 20139 (28e), 20317 (28a); Beck H T et al. 281 (10); Beechey s.n. (6e), s.n. (6e); Bello 296 (4), 304 (4), 407 (10), 606 (42), 1252 (42), 1538 (63), 1631 (12a), 2044 (63), 2065 (8), 4621, 4958 (4); Bello \& Cruz 4877 (7); Bello et al. 2740 (10); Belshaw 3147 (28d?); Beltran 32 (10); Beltran \& Foster 709 (34); Berendsohn et al. 1603 (6a); Berg et al. BG 703 (42); Berlin 237 (35), 413 (21a), 562 (42), 3501 (42), 3581 (32); Bermudez 34928 (40); Bernardi 8/158 (5?), 18316, 
20541 (28c), 7458 (40); Berry et al. 5421 (9); Bertero s.n. (6a); Betancur et al. 4970, 5070, 5084, 5124, 5215, 5430, 5440 (10); Bigay \& Irvine 806 (40); Blanchet 2324 (30); Blanco 576 (21a); Blum \& Tyson 2335 (8); Bonpland s.n. (6b); Boom 2625 (9), 4084 (28d), 9917, 10231, 10232 (40); Boom \& Mori 1947 (37), 2012, 2070 (10), 2099 (37), 2100, 2105 (10), 2119 (42), 2133 (37), 2164, 2188, 2196 (10), 2215, 2219 (37), 2254 (10), 2269 (42); Boom et al. 7843 (12a), 8712 (50), 8771 (1); Boon 10056 (6a), 9587 (6a); Bordas 4394 (28c); Bourdy 1486, 1749 (10), 1823 (28d), 1918 (28e); Bourgeau 1197 (6b); Box 876 (28a); Boyle 917 (6c), 1263 (63), 1342 (9), 1394 (3), 1426 (9), 1429 (63?), 2464 (6c); Boyle \& Ezeta 2797 (63), 2800 (3); Boyle et al. 230 (8), 1137 (10), 1139 (6c?), 1207, 1233 (63), 3896 (6a), 6888 (4); Brade 15436 (40); Braga et al. 19526 (40); Brand \& Gonzalez 509 (9); Brandbyge \& Asanza 30147 (42), 30391 (10), 30688 (17); Brandbyge et al. 30484 (10), 30569 (28e), 33516 (42); Brant \& Hazlett 2881 (42), 2884 (51); Breedlove 10220 (60), 20245, 23899, 35320 (60), 56117 (sp.); Breedlove \& Almeda 57994 (6d); Breedlove \& McClintock 34211 (6d); Breedlove \& Smith 21678 (60); Breedlove \& Thorne 30774 (60); Brenes 4790 (7), 5832, 5852, 5883 (6c), 14316 (7), 20387 (4), 23132 (6c); Breteler 3660 (40), 4733 (21b), 4935 (10), 5150 (40); Bridgewater \& Ibanez 458 (40); Brito et al. 17 (21a); Britton et al. 14448 (40); Broadway 205 (40), 3454 (28a), 4582 (6a); Brooks 12250 (40); Brown 6863 (6a), 17521 (6c); Bruijn de 1460, 1482 (40); Brunner 1157 (28c); Brunner \& Perez 1192 (28c); Buchtien 1726 (12a), 1789 (10); Bunting 6449, 6788, 9476, 11618 (40); Bunting \& Alfonzo 6451, 6941 (40); Bunting \& Arboleda 8716, 8717 (40); Bunting \& Fucci 8416 (40); Bunting \& Stoddart 8957 (40); Bunting \& Trujillo 11550, 11551 (40); Bunting et al. 7488 (40), 10895 (21a), 10964, 12055, 12408 (40); Burger \& Baker 9561 (7), 9825 (63); Burger \& Gentry 9113 (63); Burger \& Liesner 7003 (8); Burger \& Matta 4460 (63); Burger \& Visconti 10212 (6c); Burger et al. 12462 (63); Burgos 31 (40); Burkart 14558 (10), 19398 (28c); Bustamente 277 (66); Buttura 273 (10), 487 (28b); BW 70 (37), 1665 (37), 1788 (42), 2304 (26), 4103 (64), 6677 (6a), s.n. (26); Byron \& Lima 28116 (10).

Calderon 324, 1381, 1416, 1429 (6a); Caletti et al. 123, 155 (6f); Callejas \& Betancour 3518 (8); Callejas et al. 1575 (28e), 1575 (28a), 1720 (40), 1720 (28b), 5733 (10), 5747 (9), 8022, 8670 (40), 8694 (28e), 9521 (6a), 9693 (28a), 9765 (42); Calonico et al. 22945 (6b); Calzada 8 (4), 850 (6f); Camp 3680 (6a); Campbell et al. 6171, 6188, 6261, 6309 (12a), 6375 (10), 6443 (27), 6523 (25?), 6588 (16), 6798 (28a), 6808 (16), 6824 (39), 6965 (40), 6967 (28a), 7051 (1), 7077 (47), 7243 (16), 7305 (6a), 7478, 7663 (16), 8246 (12a), 8286 (40), 8441 (28a), 8532 (69?), 8809 (10), 8836 (39), 8886 (40), 8935 (12a), 8981 (28e), 9034 (42), 9136 (10), 9154 (12a), 9297 (6a), 9362 (10), 9374 (12a), 9411 (68), 9439 (6a), 9509 (12a), 9617 (10), 9937 (28e), 9976 (21a), 10148 (28e), 10461 (40), 14472 (21a), 15107, 15161, 15323 (10), 21260 (69); Campos 2728 (6d); Capucho 359 (40), 591 (21a); Carauta et al. 3777 (28b), 6784, 6786 (40); Carballal \& Cardiel 156 (6a); Carballo 108 (63), 157 (3); Cardenas 1171 (10), 1590 (28d); Cardiel \& Carballal. 139 (39); Cardozo 147 (59); Cardozo \& Wingfield 190 (6a); Cardozo et al. 2576 (10); Carillo 397 (34); Carillo \& Miranda 248 (28e); Carvalho 4100 (40); Carvalho \& Chautems 1632 (28d); Carvalho et al. 678 (30), 3403 (30), 6691 (28d); Cascante 604 (6c), 642 (4); Cascante et al. 141, 385 (63); Castillo 1004 (4), 1477 (40), s.n. (6b); Castro 1 (17), 20 (6b); Cavalcante 2997 (16); Cavalcante et al. 2111 (28d); Cazalet \& Pennington 5068 (40), 7513 (10), 7554 (42); Cedeño 194 (6a); Cedillo 31 (9); Cerón 240 (10), 2639 (39?), 299 (40), 378 (21a), 788 (28e), 1300 (40), 14341 (16?), 3479 (1), 3637 (12a), 3696 (42), 3751 (12a); Cerón \& Cerón 4576 (39); Cerón \& Gallo 5115 (10), 5164 (28e); Cerón \& Hurtado 3983 (12a), 4156 (10); Cerón \& Iguago 5307 (12a); Cerón \& Montalvo 20963 (37); Cerón C \& M 3054 (10); Cerón et al. 2138 (40), 2185 (10); Chacón 11 (54), 105, 246, 283 (63), 697 (42), 1122 (9); Chacón \& Herrera 1642 (63); Chacón et al. 1773 (6c); Chatrou et al. 128, 139 (10); Chavarria 469 (9), 488, 778 (6b), 1198 (63); Chaverri 287 (6a); Chavez 487 (63); Chiea 386 (10); Chimbo \& Chamba 34, 110 (20), 114 (10); Choussy 1604 (6b); Churchill 826 (13); Churchill \& de Nevers 4327 (40); Churchill et al. 4533 (63), 4765 (8); Cid 2885 (37); Cid \& Lima 3328, 3328 (21b), 3518 (39); Cid \& Nelson 2830, 2925 (10), 3062 (39); Cid \& Ramos 1022 (21b); Cid et al. 109 (28e), 115 (21b), 133 (28e), 503 (21b), 781, 789 (28d), 
998 (64), 1232 (21b), 1440 (1), 1567 (15), 1575 (21a), 1688 (21b), 1750 (15), 1835 (1), 1836, 1836 (21b), 1962 (15), 2058 (28d), 2138, 2138, 2374, 2374 (21b), 3084 (21a), 4525 (12a), 4847 (40), 4915 (39), 6525 (40), 8278 (10), 8604 (34); Cid Ferreira 5612 (1), 5670 (16), 5693 (1), 5712 (57), 5758 (1), 5863 (21a), 5920 (55), 5973 (57), 7973 (21b), 8646 (57), 8854 (10), 8891, 8902, 8930 (6a), 8961 (28d), 8973 (28e), 9035 (28d), 9306 (21b), 9569 (1), 9693 (18), 8989 (21a); Cid Ferreira et al. 5116 (28e), 5132 (32), 5301, 5314 (10), 5974 (16), 6510 (10), 6982 (28d), 7002 (10), 7546 (25), 7945 (25), 7973 (21b), 9875 (1), 9904 (10), 10485 (28a), 10505 (15?), 10877 (12a), 10906 (28e); Clark \& Maquirino 7641 (47), 8354 (47); Clark \& Maquirino 7984 (1); Clark H L 7237 (1); Clark J L 2298 (38), 4671 (4); Clark J L \& Watt 806 (10); Clark J L et al. 1100 (42), 3382 (28a); Clarke D 3132 (64), 3625 (37), 3627 (68), 3801 (37), 4461, 4594 (25), 5004 (68); Clarke D et al. 606 (21a), 6311 (64), 6420, 6515, 6515 (21a), 7117 (68), 7392 (25), 7677 (10), 7719 (68), 8056 (25), 8820 (40), 9662 (64); Clemente 7021 (40); Cogollo et al. 2563 (6a), 3321, 3573 (12b); Colella et al. 2035 (28e); Conceição 184 (39), 190 (10), 198 (21a); Conrad \& Gallegos 2856 (4); Contreras 1218 (6f), 3338 (6d), 3361 (6f), 4212 (6d), 5456 (6f), 6675 (4), 6940 (42), 7350, 7391, 7714, 9307 (6f), 9490, 9871, 10058 (6d), 10349, 10360 (6f), 10663 (6d), 10674 (4), 10675 (4); Conzatti et al. 3244 (6b); Cook \& Griggs 408 (4); Cooper \& Slater 164 (8), 208 (42), 229 (8); Cordeiro et al. 679 (28b), 754 (28b); Cordero 253 (49); Cordovil et al. 124, 304 (40), 372 (10); Cornejo \& Bonifaz 3680 (12a), 4219 (28e), 6603 (61); Correa \& Dressler 735 (3), 1119 (54); Costa 59 (28d); Costa \& Assunção 384 (47), 779 (1); Costa \& Horta s.n. (28b); Costa et al. 393 (28b), 22162, s.n. (40); Cremers 4505 (21b), 7345 (40), 7726, 11113 (21a); Cremers \& Gautier 11959 (19); Cremers \& Petronelli 11868 (19); Croat 11300 (42), 18453 (21a), 20760 (10), $22184 \mathrm{~A}$ (6a), 24734 (6f), 25935 (54), 33783 (54), 35061 (8), 41809 (51), 41959 (6a), 44753 (69?), 49955 (7), 57972 (10), 71129 (sp.); Croat \& Hannon 64414 (6d), 65773 (6b); Crueger 291 (6a); Cruz 3947 (40); Cuatrecasas 2864 (21b), 4706 (40), 8699 (10), 10807 (40), 13133 (10), 14103 (13), 15218 (44), 16598 (12b), 16748 (42), 21292 (61), 22337 (48), 26150 (10); Curran 234 (28c), 265 (40).

Daly \& Balick 2114, 2115 (28e), 2116 (10); Daly et al. 513 (40), 531 (40), 1659 (40), 3879 (6a), 3882 (10), 3994 (21a), 4002 (64), 4027 (19), 4179 (18), 4205 (10), 5452 (15), 5624 (28e), 5770 (41), 6166 (28e), 6222 (68), 6363 (28d), 6434 (28e), 6547 (28e), 6549 (10), 6723 (10), 6921 (37), 6964 (10), 7009 (10), 7232 (10), 7275 (28a), 7426 (12a), 7520 (12a), 7522, 7525 (28e), 7526 (33), 7625 (28d), 7707 (21a), 7731 (39), 8109 (28e), 8197 (37), 8240 (10), 8555 (40), 8592 (10), 8713 (28a), 8850 (40), 8884 (64), 9187 (39), 9720 (40), 10064 (6a), 10972 (12a), 11108 (10), 11124 (28e), 11289 (21a), 11649 (10); Davidse 24460 (6c?); Davidse \& Gonzalez 2351 (40), 15543, 16158 (21b), 19219 (40), 19280 (28e), 19481 (40); Davidse \& Hamilton 23533 (54); Davidse \& Herrera 31366 (9); Davidse \& Holland 36491 (42), 36522A, 36665 (4), 36777 (42); Davidse \& Martinelli 10321 (21b); Davidse \& Meadows 35771 (42); Davidse \& Whittemore 5133 (6d); Davidse et al. 20490 (6f), 23266 (6b), 23303 (9), 34534 (42), 35864 (42), 37299 (5), 37488 (6b); Davidson 46 (6c); Davidson \& Martinelli 10067 (1), 10321 (21b); Daza et al. 16282 (40); de Granville 9172 (21a); de Granville et al. 967, 7404, 7519, 7876 (21a), 8065 (40), 9230, 9843 (37), 10743 (21a); De Jong 177 (28a); de Lima et al. 579, 2306 (40); De Nevers et al. 5202 (54); de Oliveira 305 (40); Defler 291 (18), 295 (58); Degen 740 (28c); Degen \& Zardini 315, 363 (28c); Del Aguila et al. 5253 (28d); Delascio \& Liesner 6991, 7081 (40); Delgado 208 (10), 965 (6a), 1014 (21a); Delnatte 1615 (19); Delprete 8517 (21a); Devia 795 (40), 1209 (12b); DeWalt et al. 765 (10); Deward 201 (21a); Díaz \& Jaramillo 1261 (10), 1431 (28e); Díaz \& Niño 1990, 266 (10); Díaz \& Ramirez 9565 (17); Díaz \& Torres 7780 (20); Díaz et al. 1302 (40), 4133, 4180 (28d), 591 (37), 7864 (32); Dick 137, 172 (1); Dik 344 (34); Dionisio 3014 (21a), 16414 (10); Dodson 5135 (40), 5203 (44), 5812 (4); Dodson \& Gentry 10115 (6a), 12420 (9); Dodson \& Thurston 14225 (28e); Dodson et al. 6742, 14883 (10); Dominguez Vásquez 619 (6f), 666 (4); Dorantes et al. 3228 (4), 3768 (6b); Dorr \& Valdespino 6342 (40); Dorr et al. 4695 (40); Dryer 1148 (7), 1328 (63), 1577 (7), 1685 (6c); Dubs 1293 (10), 1589 (28a), 1919 (10), 2000 (40); Ducke 1060 (16), 11260 (10), 1705 (42), 1857 (12a), 3721 (21b), 7690 (57), 7900 (1), 18485 (39), 20530 
(28d), 25461 (55); Dugand \& Jaramillo 4142 (40); Duivenvoorden et al. 891 (10), 1441 (28a), 1498 (69?), 1540, 1574 (21a), 1690 (69?), 1880 (21a), 2766 (17); Duke 5627 (6a), 5651 (40), 14550 (9), 14613 (42), 16082 (12a); Dulmen van 372 (25); Dunlap 506 (40); Duque-Jaramillo 2048 (12a), 2101 (37), 2375 (69); Dusen 15097 (28b); Duss 1499, 2314 (28a), 3301, 591/4533 (6a); Dwyer 10914 (6d), 11260 (6f); Dwyer \& Macbryde 9782 (28e).

Edwards 410 (6d), 624 (6f); Eggers 635, 914 (6a), 1198 (40), 1214 (6a), 14284 (40), 15602, 15718 (6a); Egler \& Irwin 45935 (28d); Eiten G \& L T7066 (40); Ek et al. 769 (21a); Ekman 2005 (40), 2010 (28c), 7655, H5209, H9524 (65); Elcoro 77 (40); Engel \& Tarcy 4 (28d); Engevix 14883 (28b); Ernst 1772 (6a), 1818 (10); Escobar et al. 8210 (10); Espina 2059 (61); Espina et al. 1399 (13), 2620 (12b); Espinal.\& Delgado 1787 (10); Espinoza 223, 688 (4); Espinoza \& Coba 466 (39), 473 (10); Espinoza \& Gualinga 835 (10); Espinoza et al. 1185 (63), 1244 (4?); Estrada 832 (24), 2016 (46); Estrada \& Volio 2142 (sp.); Estrada et al. 1227 (40); Evans 1557 (42), 1557 (sp.), 1581 (9); Evans \& Koemar 2574 (40); Evans \& Peckham 2859 (64), 2886 (21a).

Faber-Langendoen \& Renteria 1044 (12b); Faber-Langendoen et al. 224 (13); Fagerlind \& Mibom 2492 (6a); Farinas et al. 612 (21a); FDBG D101 (21a), 1071 (3807) (16?), 2033 (40), 2527 (6a); Fedlmeier 10 (37); Felfili et al. 317 (28b); Fernandes et al. 151 (40); Fernandez 303 (68), 442 (63), 511 (12a), 4650 (28d), 7855 (21a); Fernandez et al. 10899 (10); Ferraz 488 (28b); Ferraz \& Mello 721 (28b); Ferraz et al. 826, 827 (10); Ferreyra 19471, 19474 (35); Ferrucci et al. 645 (28c); Feuillet 46 (37), 1584 (40), 1584 (40), 2328 (40), 9983 (21a), 10069 (21a); Fiebrig 5293 (28c); Figueiredo 142 (28e); Figueiredo et al. 933 (10), 955 (40); Fleury 368 (21a), 375 (1), 522, 841 (40), 1365 (21a), 1631 (21a); Flores \& Terpán 748 (6e); Flores et al. 901 (6e); Foldats 181 A (40); Folli 635, 700 (29), 1243 (28d), 1427 (31); Folsom 2612 (13), 2619 (36), 3856, 4169 (8), 9404 (3), 9843 (54); Folsom et al. 5687 (6c); Fonseca 578 (6b); Fonseca et al. 2011 (28b); Forero \& Wrigley 7110 (39); Forero et al. 6334 (39), 7202 (62); Forsyth s.n. (6a); Forther 2755 (6f); Forther et al. 10257 (6a); Foster 2749 (12a), 2928 (8), 3580 (28d), 3827 (28e), 4120 (6a), 4214, 4373 (17), 5888, 8558 (28e), 8756 (28d), 8804 (28e), 8865 (12a), 9224, 9275 (28e); Foster \& d'Achille 10043 (28a), 11638, 11973 (10); Foster \& Jansen 8295 (40); Foster \& Wachter 7413 (10); Foster et al. 107 (28e), 4906 (68), 8932 (27), 10369, 11748 (10); Franco et al. 1302 (62), 1804 (12b), 5167 (10); Frankie 40 (63), 96c (6b); Freire \& Cerda 149 (16); Freire \& Chavez 5372 (10), 5420 (42); Freire \& Inmundo 3211 (12a); Freire \& Naranjo 681 (42), 682 (34); Freire \& Suarez 5116 (28e); Freire et al. 2472 (28e); Freitas 78 (41); Freitas et al. 536 (55); Froes 11699 (40), 20451 (28e), 21209 (40); Fuchs \& Zanella 22001 (61), 22074 (12b), 22356 (61), 22361 (3); Fuentes 265 (6c), 267, 653 (63); Fuentes \& Fuentes 406 (4); Fuentes et al. 1069 (28e); Funk et al. 10772 (23).

Galdames 647, 1075 (8); Galdames et al. 572, 609 (54?), 643 (63), 3381, 3480 (6c), 3810 (8); Galeotti 4 (4), $7247 D$ (6b), s.n. (4); Gamboa 42 (4?); Gamboa \& Picado 123 (8); Gamboa et al. 16 (6c); Gandara \& Dorantes 56 (6f); Garcia 64 (4), A69 (6f); Garcia-Barriga 18042 (10); GarciaBarriga \& Lozano 18447 (40); Garwood et al. 810 (4?); Gasson et al. 5880 (28b); Gastony et al. 140 (40); Gentle 2899, 2912, 2944, 3405 (6d); Gentry 8362 (6f), 34931 (61), 35691 (44), 41202 (40), 43298 (28e), 43312 (28a), 43313 (28a), 43375 (28e), 43379 (28e), 43431 (10), 43448, 43462, 43487, 43540, 43554, 43584, 43675, 43675 (28e), 4905 (8), 54085 (40), 54085 (40), 54110 (40), 66143 (28c), 66170 (10), 71760 A (3); Gentry \& Clewell 7047 A (54); Gentry \& Daly 18259 (18); Gentry \& Diaz 28268 (10); Gentry \& Emmons 38771 (17); Gentry \& Estensoro 70286 (37), 70354 (10), 70483 (28e), 70573 (28a); Gentry \& Faber-Langendoen 62795 (36); Gentry \& Jaramillo 41310 (37); Gentry \& Monsalve 53145 (10); Gentry \& Nelson 69064, 69276 (55); Gentry \& Nunez 54190 (28a); Gentry \& Ortiz 78551 (9), 78570 (8), 78602 (63), 78610 (9), 78629 (44), 78631 (9); Gentry \& Renteria 23803 (36); Gentry \& Revilla 16663 (39), 20451 (34); Gentry \& Sanchez 64987 (17), 65007 (21a); Gentry \& Smith 44891 (40); Gentry \& Stein 47268 (21a); Gentry \& Vásquez 42399 (42), 42420 (10); Gentry \& Young 31829 (6a); Gentry \& Zardini 49271, s.n. (40); Gentry et al. 9069 (40), 18858 (28b), 19056, 21967, 26963, 27051 (10), 28017 (37), 28434 (11), 28693 (63), 28993 (37), 29176 (28e), 29548 (10), 29630 (12a), 29714 (16), 31268 
(28e), 31274 (21a), 31513 (42), 31531 (28d), 31685 (17), 31694 (10), 32220 (4), 32309 (42), 32351 (4), 32418 (9), 32450,32554 (4), 32595 (6f), 34935 (10), 36245 (28e), 36288 (21a), 36565 (42), 38095 (28e), 39686 (39), 39739 (42), 41677 (1), 41750 (21a), 41978 (28e), 42146 (40), 42624 (28e), 42655 (33), 42681 (39), 42740 (37), 42748 (10), 42776 (42), 42882 (10), 42883 (10), 42884 (10), 42926 (39), 42947 (28e), 42958 (42), 42972 (39), 43011 (28e), 43021 (42), 43049 (37), 43051 (39), 43077 (42), 43112 (28e), 43878 (4), 43963, 44035A (6c), 45285 (10), 45301, 45357, 45376, 45472 (10), 45577 (28a), 47694, 48112 (10), 48283 (36), 48817 (9), 48825 (10), 48828 (6c), 51065 (40), 51439 (25a?), 53365 (12b), 53691 (36), 54012 (10), 56934 (13?), 59372, 59372, 59384 (28c), 60908 (27), 60922 (37), 61634 (39), 62795 (36), 71564 (7), 75061 (10), 75806 (12b), 75897 (44), 76441 (17), 76444 (1), 77093 (28e), 77104 (42), 77459 (21a), 78629 (3), 78671 (42), 78729 (12a), 79429, 79446, 79506 (8), 79554 (9?); Gentry H S 5918 (6b); Gereau \& Taylor 3473 (63); Giardano et al. 877 (28b); Gillespie 993 (40); Gillespie et al. 1377 (64); Giordano 1700 (10); Giulietti et al. 3504 (28b); Glaziou 1141 (40), 9712 (1); Gleason 443 (21a); Gomes da Silva et al. 62, 177 (28b); Gomez 20711 (6a), 20742 (42); Gomez et al. 320, 343, 693 (21a), 19076 (28e), 20382 (6a), 20846 (63), 20969 (8), 22766 (63), 23008 (6b), 23288 (63?), 23288 (63), 23306 (8?), 23306 (6c?), 23343 (42), 23867 (sp.); Gomez-Laurito 8820, 8380 (67), 9915 (9), 11930 (10); Gonzalez 3152 (8), 3621 (40); Gonzalez \& Aguilar 245 (8); Gonzalez \& Hernandez 368 (6b); Gonzalez \& Porras 3911 (22); Gonzalez et al. 1272 (6b), 1711 (24); Goodfriend s.n. (11); Graham 583 (28d); Graham \& Schunke 147 (12a), 902 (10); Grandez 1087 (28e), 2191 (34), 266, 318, 334, 361, 514, 557 (28e); Grandez \& Jaramillo 781 (34); Grandez \& Vásquez 233 (28e); Grandez et al. 2526 (sp.); Granville de 1267 (21a), 360 (40), 447, 3505 (19), 4655 (37), 7566 (64), 11170 (19), B4690 (28d), B4791 (21a); Granville de et al. 7628 (42), 7652 (26), 7724 (21a), 7749 (19), 8072 (26), 8121 (21a), 8821 (19), 9256 (21a), 10707 (26), 11962, 12008 (21a), 12028 (40), 12351 (21a); Grayum 1146 (54), 2525 (6a), 3387 (9), 5608, 5973 (8), 9626 (9); Grayum \& Longino 9307 (8); Grayum \& Sleeper 3452 (10); Grayum et al. 10551 (66), 4010 (sp.), 4472 (9?), 5019 (63), 5507 (8), 6180 (63), 6226 (4), 7943 (sp.), 8025 (9), 8261 (sp.); Grenand 1527 (16), 3181 (64); Grijalva 2696 (6b), 2853 (6c), 3072 (6b); Grijalva \& Ayesta 2708 (6b); Grijalva \& Estrada 2533 (6b); Grijalva \& Soza 3725 (42); Grijalva A \& M V 1459, 1806 (6b); Groppo 874 (28b); Groves-Raines \& Prescott 177 (39); Guanchez 308 (28d); Gudino 379, 604, 616 (15); Gudino \& Grefa 1817 (10), 1818 (39); Gudino \& Papa 1876 (40); Gudino et al. 861 (6a), 893 (37), 902 (6c), 902 (6a), 1750 (10), 1765 (28e), 2103 (10); Guillen \& Chore 3379 (21b); Guillen \& Coria 1513, 1680 (21b); Guillen \& Rosa 3321 (21b); Guppy 652 (68); Gutierez et al. 486 (6d); Guttierez 92 (40), 911 (6f); Guttierrez 79 (40); Guzman et al. 565, 1663 (6b).

Haber 11797 (9), 1258 (63), 301, 498 (6c), 811 (4), 874 (6c), 9908 (63); Haber \& Bello 1676, 1961, 2709 (4), 3799 (10), 3810 (6c), 4028 (63), 6951 (4), 7054, 7111 (6c), 7904, 8380 (63); Haber \& Cruz 7102 (8); Haber \& Ramirez 11783 (10); Haber \& Zuchowski 10011 (6c), 11212 (6a); Haber \& Zuckowski 9364 (10), 10791 (7), 10792 (8); Haber et al. 4825 (23), 4932 (63), 5583 (7), 11670 (66); Haber ex Bello 3809 (63); Hage \& Brito 2198 (10); Hage et al. 2374 (30); Hahn 1248 (6a), 487 (10), 806 (6a), s.n. (6b); Hahn W 3616 (21a); Hahn W \& Tiwari 5213 (40); Hahn W et al. 732 (28c), 916 (10), 1017, 1209, 2627 (28c), 5703 (40); Hamilton \& D'Arcy 682 (8); Hammel 4567 (34?), 11171 (9), 21062 (7); Hammel \& Grayum 17333 (42); Hammel \& Haber 13910 (6c); Hammel \& Robles 16760 (46); Hammel \& Trainer 12844 (3); Hammel et al. 15258 (6c), 15720 (6d), 16815 (9), 17058, 17515 (3), 17566 (sp.), 17718 (10), 18425 (9), 19412 (10), 21298, 21570, 21616 (21a), 21662 (64), 24065 (7); Hampshire et al. 721 (5); Harley 18166, 20001 (40); Harley et al. 10598, 18166, 20011 (40), 25937 (28b); Harling 4699 (61); Harmon 33 (36); Harris 5384, 10853, 10960, 12815 (6a); Harris \& Britton 10754 (6a); Hartshorn 1004 (42), 1408 (3), 1450 (4), 2120 (7), 2697 (28e); Hartshorn et al. 2627 (28e), 2628 (28d), 2628 (28a), 2651 (28e), 2669 (64), 2697 (28e), 2719 (28a), 2719,2769 (28e), 2769 (64), 2851 (40), 2942 (10); Hassler 3499, 5161 (28c), 5187 (10), 10034 (28c), 11204 (40); Hatheway 1356, 1409 (6c); Hatschbach 14452 (28c), 14535 (28b), 43139 (40), 45227 (28b), 47687 (31?); Hatschbach \& Barbosa 58242 
(28c); Hatschbach \& Guimaraes 19415 (28c), 45014 (40), 47017 (28b); Hatschbach \& Nicolack 53397 (28b); Hatschbach \& Silva 51590 (28b), 60384 (40); Hatschbach et al. 52410 (28c), 63838 (40), 63851, 64996, 66875 (10), 68860 (28b), 72158, 74130 (10), 74565, 76382 (40), 76556 (28c); Haught 2198 (10), 4214 (40); Hawkins 1221 (4); Hawkins \& Merello 776 (6d), 823 (4), 826 (sp.), 829 (42); Hazlett 1688 (6f), 2761 (42), 2899, 3236 (6d), 3240 (6f), s.n. (42); Hazlett \& Brant 8068 (42); Henderson et al. 327 (21a), 398 (39), 656 (40); Henkel et al. 2885 (40), 3273 (21a); Henz 33217 (28b), 35544 (28b); Hequet 393, 657 (21a); Herb Ventenat s.n. (6a); Heringer 316 (40); Heringer et al. 1812 (40), 2407 (28b), 2934, 2972, 3351, 3443 (40), 4497, 4831, 5517 (28b), 5585, 5690 (40), 5829 (28b), 5951, 5987, 7039 (40), 17331 (28b); Hermann 388 (40); Hernandez 1401 (9); Herrera 100 (6c), 659 (sp.), 699 (9), 867 (63), 918 (9), 919 (6d), 1053 (sp.), 1286, 1397, 1670 (63), 1879 (6c), 1964 (10), 2160 (28e), 3278 (63), 4162 (24), 4312 (12a), 4841 (42), 4876 (24), 5527 (6c), 5699 (63), 5927 (6c), 6365 (63), 7656 (67); Herrera \& Chacon 2343 (12a); Herrera \& Rivera 857 (4?); Herrera \& Schiaffino 103 (28c); Herrera \& Schik 3808 (sp.); Herrera et al. 424 (28e), 551, 3973 (9), 7392 (24); Herzog 313 (28e); Heyde \& Lux 3276 (5); Hill 13073 (21b); Hinton 3818 (6e); Hinton et al. 6189, 7542, 7553, 10097 (6e); Hiudobro 1930 (28c); Hoehne 30827 (10); Hoehne \& Gehrt 17721 (28b); Hoff 5413 (40), 7380 (37); Hoff \& Cremers 6624 (21a); Hoffman 3713 (21a), 834 (40); Hoffman \& Artes 3765, 3842 (40); Hoffman \& Roberts 2507 (40); Hoffman et al. 1526 (40); Holdridge 6226 (6a), 6752 (7); Holm-Nielsen \& Jeppesen 6194 (10); Holm-Nielsen et al. 21668 (1), 21923, 22482 (10), 22594 (28e); Holst 4425 (4); Holst et al. 5133 (6d), 5142 (4), 5364 (6d); Homeier 1112 (7); Hoomans 7 (12a); Hoover 225 (4); Hopkins et al. 871 (40); Horta et al. 302 (28b), 316 (31?); House 2195 (6d); Howard \& Gonzalez 1253 (40); Howard R A \& E S 8238 (40); Huashikat 115 (12a), 126 (25), 136 (28e), 1036, 1555, 1693 (28e); Huber 4394 (39); Huber \& Weissenhofer 1566 (46), s.n. (42); Huber O 328 (10); Huber W \& Wassenhofer 427 (42); Hurtado \& Alvarado 320 (28e), 911 (10); Hurtado \& Neill 217 (38).

Ibanez et al. 790 (42); Ibarra 449 (4), 765 (9); Ibarra \& Gomez 1350, 1554 (4); Ibarra \& Sinaca 1757 (9), 1966 (42); Idrobo 2168 (10), 2594 (40); Imray 165, 316 (6a); Irvine 291 (21a); Irwin 2253 (28b); Irwin \& Soderstrom 6929 (28b); Irwin et al. 8455 (28b), 11982, 17749 (40), 18189 (10), 47327 (21a), 47595 (64), 48233 (28d), 48434 (42), 48503 (10), 55759 (21a).

Jangoux \& Ribeiro 1525 (10); Jangoux et al. 1732 (40); Janovec et al. 1924 (28d); JansenJacobs et al. 609, 1087 (40), 1658 (21a), 2373 (40), 2487 (28e), 2949 (40), 5745 (37), 5782 (42), 5933 (40), s.n. (64); Janzen 10842, 12033 (6b); Jaramillo 3425 (35), 7747 (10), 14165 (35); Jaramillo \& Grijalva 11419 (10); Jaramillo \& Marcos 694 (17); Jaramillo \& Zak 591, 7505, 7765, 7866, 7987, 8049, 8061, 8147 (10); Jaramillo et al. 167 (42), 206 (40), 300 (28e), 359 (34), 387, 656 (10), 1080, 1186 (27), 1220 (10), 1358 (16?), 30770 (37), 31111, 31374 (17); Jardim 1098 (28e); Jardim et al. 225 (30), 609 (37), 713 (37), 1732 (28d); Jenaro Herrera 1-2/90 (47), 2-1/85 (18), 3-2/184 (21a), 6/69 (28e), 7-3/8 (41); Jeremie 888 (6a); Jimenez 1034 (63), 3120 (6b), 4164 (40), 534 (66), 535 (6b); Jimenez \& Acosta 2261 (42); Jimenez \& Lopez 181 (9); Jimenez et al. 660 (12a), 666 (10), 1458 (23); Jimenez-Saa 1536 (37), 1851 (10); Johnston 1 (42), 1700 (10); Jong 177 (40); Jorgensen et al. 1120 (10); Jorgenson 3684 (10); Josse \& Valencia 788 (6a); Juncosa 1233 (13), 1717 (12b); Jurgensen 199 (6b).

Kajekai et al. 13 (12a); Kallunki et al. 361 (28d), 585 (30), 721 (28a), 732 (28b); Kapos 1583 (6a); Kawall \& Anunciaçáo 89 (28b); Kawasaki et al. 7578 (10); Kayap 69 (10), 398 (1), 831 (40); Kelloff et al. 695 (40); Kernan 599, 814 (10), 1214 (24); Kernan \& Phillips 503 (12a), 603 (8), 687 (42), 944 (8), 1020 (43), 1020 (42), 1203 (10); Killeen 3883, 4464 (37); Killeen et al. 2932 (10), 2933 (28d), 2986 (28e); Killip \& Smith 26506, 26793 (28b), 28968 (28e); King 506 (27); Kirkbride \& Duke 5182 (54); Kirkbride et al. 3420 (40); Klein 603, 2298 (28b); Klug 630 (1), 1960 (42), 2090 (41), 2299 (12a), 2300 (1), 2699 (12a), 2998 (40); Knapp \& Cress 4339 (7), 4386 (sp.); Knapp \& Mallet 6449 (28d); Knapp \& Schmalzel 3611 (28a); Knapp \& Sytsma 2483 (69?), 2580 (8); Knapstein 15 (63); Konno 109 (28b); Korning \& Thomsen 47398, 47465 (1), 58648, 58679 (28e); Krapovickas 17099 (28c); Krapovickas \& Cristobal. 39612 (28b); Krapovickas \& 
Schinini 31860 (28b); Krapovickas et al. 23876, 44152 (28c); Kriebel 1915 (6c); Kriebel et al. 3985 (6a), 4019 (40); Kroll 498 (37), 791 (28e); Krukoff 1123 (28d), 1196 (39), 1305 (21a), 1672 (39), 4556 (18), 4608 (40), 5035 (39), 5225 (37), 5263 (10), 5403 (28d), 6492 (37), 7154 (1), 8153 (10), 8181 (42), 8240 (27), 8250 (37), 8503 (12a), 8753 (17), 10849 (37), 11105 (28d); Kujikat 317 (42), 376 (28e), 436 (10); Kukle 72 (55); Kunkunas 227 (1); Kuno 361 (28e); Kvist \& Freitas 775, 870, 1618 (40), 1843, 2002, 3341, 3439, 4424, 5172, 7113, 7606 (28e).

Laguna 129 (8); Langlasse 917 (6b); Lanjouw 833 (10), 836 (42); Lanjouw \& Lindeman 2500 (26), 2900 (42); Lao 54 (28e), 389 (6c); Lao \& Holdridge 174 (8); Lao \& Maasola 459 (42); Lasser 1039 (42); Laurenio \& Ferraz 716 (28b); Lawton 1275 (6c); LBB 9841 (10), 10717 (42), 10796 (21a), 11024 (10), 16283 (6a); Leblond 61 (21a); Le Goff \& Hoff 164 (40); Lehman \& Oliveira 601 (28e); Lent 1705 (6c), 2457 (8), 613 (4); Leonard 9279 (40); Leonard E C \& G M 12387 (40); Lescure 2194 (28d); Leveau 172 (28d), 304 (28e); Level 3 (42), 123 (21b); Lherminier s.n. (6a); Liesner 2039 (9), 16316, 16986 (1), 17529 (21a), 24540 (21a), 25567 (64), 893 (4); Liesner \& Delascio 21922 (40); Liesner \& Gonzalez 9344 (40), 10573 (21a), 11446 (40), 13143 (21a), 13153 (40); Liesner \& Guariglia 11756 (6a); Liesner \& Holst 18968 (40); Liesner \& Mejia 26038 (42), 26042 (9); Liesner et al. 9593, 12565 (40); Lima de 88 (28b); Lima de \& Saraiva 211, 266 (10); Limbach 112 (42); Lindberg 273 (28c); Lindeman 5045 (10), 5486 (40); Lindeman \& de Roon 890 (42); Lindeman \& Haas 1593, 2853, 3323 (28c); Lindeman \& Lescure 6782 (40); Lindeman et al. 97 (26); Liogier \& Martorell 35075 (6a); Liogier A \& P 18883 (6a); Lister 201 (21a); Little 6404 (61), 13058 (6a), 25202 (3); Little \& Dixon 21055 (44); Little \& Little 9702 (1), 9733 (39); Little et al. 747 (21a); Lleras et al. 16995 (42); Loefgren 10765 (28c), 10781 (28b); Lombardi 1527 (10), 1998 (28d), 2078 (10); Londono et al. 1541 (10), 1610 (39); Lopes \& Andrade 502 (29); Lopez s.n. (6a); Lott 703 (6b); Lott et al. 2220, 3130, 3329, 4107 (6b); Loubry 789 (28d), 1729 (26), 1774 (47); Loureiro \& Coelho 15521 (21a); Lourenzo SW2243 (28b); Lowrie et al. 201 (28e), 211 (21a), 371 (10), 436 (10), 481 (21b), 533, 605 (28e), 705 (10), 718 (21a), 719 (10); Lozano et al. 821 (sp.); Luetzelburg 25873 (40); Lund 3243 (28c); Lundell 18164 (6f); Lundell \& Contreras 19481 (6d), 21141, 21142 (6a); Luteyn 3672 (63); Luteyn et al. 9092 (28e), 12019 (10), 12127 (12b).

Maas et al. 4487 (40), 4487, 4536 (28e), 4588 (12a), 5469, 5564 (40), 6573, 6635, 6810, 6810, 6836, 6836 (21b), 13266 (10), P12844 (1); Macbride 5444 (40); MacDougal. et al. 3314 (4); Macedo 2011 (10); Machuca \& Chazaro 6638 (6e); Macia \& Quisbert 3893 (10), 3912 (12a), 4796 (10); Maciel et al. 799 (1); Madrinan \& Barbosa 142 (40); Magallanes 4240 (6b); Maguire \& Politi 28599 (28d); Maguire et al. 41598 (1), 42552 (42), 56367 (28b), 56769 (42), 56781 (40); Makrinius 810 (6b); Malave \& Canales 22 (40); Mamede et al. 221 (28b); Mara 1298 (9); Marcano-Berti \& Pena 518-979 (10); Marcano-Berti \& Sanchez 982-065, 982-066 (6a); Marcano-Berti et al. 142-980, 174-979 (40), 37-1-77 (28e); March 351 (6a); Marin 217 (43), 430 (12a), 839 (21a), 855 (10), 1764 (39), 1905 (64); Marquete et al. 785 (40); Marshall 11597, 12311 (6a); Marshall et al. 386 (42), 405 (6d), 418 (4), 418 (3f?); Martinelli 1074 (28b), 7087 (21a); Martinelli et al. 7087 (40), 10273 (28b), 10576 (40); Martinez 473 (6b), 622 (6e), 667, 694 (6a), s.n. (5); Martinez \& Lombera 26179 (42); Martinez et al. 26474 (6f), 32282 (6b); Martius s.n. (1), s.n. (28d); Marulanda \& Betancur 2183 (28e); Marunak 961 (28c); Mason 13812 (40); Mathias 360 (6b); Mathias \& Taylor 5649 (28e); Mattos Silva \& Brito 661 (10); Mattos Silva \& dos Santos 819 (28d); Mattos Silva \& Hage 594 (40); Mattos Silva \& Sant'ana 2933 (30); Mattos Silva et al. 440 (30), 719 (30), 1241 (40); Matuda 2449 (4), 2616 (42), 3085 (6f), 3269 (6d), 3458, 4168, 15500 (4), 16639 (6b), 17677, 18653 (4), 18860 (5); Mc Dowell 3520 (21a); McDaniel 16216 (28e); McDaniel \& Rimachi 17016, 17567 (28e), 18296 (17), 18391 (28e), s.n. (41); McDowell 4422 (37); McDowell \& Gopaul 3520 (21a); McPherson 7345 (69?), 7698 (8), 7724 (7), $7841 A$ (6c), 8413 (54), 8564 (8), 8607, 8627 (7), 8729 (10), 8772 (8), 8772 (6a), 8834 (6c), 9076 (7), 9162 (63), 9180 (12a), 9725 (4), 9885 (6c), 10244 (54), 10458 (34), 10472 (6a), 10671 (63), 10949 (12a), 11609 (63), 11814 (8), 11866 (13), 12086 (7), 12175 (40), 12192 (63), 
12234 (42), 12260 (40), 12270 (42), 12491 (6c), 12547 (54), 13319 (36), 13624 (63), 15031 (13?), 15356 (10), 15912 (6c); McPherson \& Merello 8184 (13), 8204 (36); Meier 241 (40), 1230 (10), 3120 (40), 3316, 3621 (10); Meier \& Kunert 4905, 4911 (6a); Meier et al. 5651 (10); Mello \& Coelho 2958 (55); Meneces \& Terceros 321 (28e); Menedo 660 (39); Mereles 3851 (28c); Mexia 1260 (6b), 4555 (29), 5099 (10), 7200 (40), 8900 (6e); Miller 495, 631 (68); Miller \& Tenorio 705 (4); Milliken 3 (40), 796 (40), 1829, 2189 (40), 2316 (10), 2336 (42); Milliken et al. 1679 (64), 345 (25); Miranda 8407 (6b); Molas 735 (10); Molas \& Brunner 949 (28c); Molas et al. 711 (28c); Molina 8423 (6d), 15410 (6f); Molina \& Montalvo 21611 (6a); Molina \& Sabatier 2491 (1); Molina A \& A 12634, 12646 (5); Molina et al. 16910 (5); Monro et al. 2033 (6a); Monsalve 573 (40), 1673 (13), 1929 (12b); Monterrosa 177 (6a); Monterrosa et al. 186 (5); Mora 906 (3); Moraes 671 (28e); Moraga 292 (6d), 346 (63); Morales 163 (sp.), 163 (sp.), 3938 (12a), 5670 (4?), 5671 (9), 8145 (8); Moran et al. 6474, 6844 (9); Morawetz \& Wallnöfer 11-121085 (37), 111-281085 (42), 112-26985 (12a), 113-21085 (10), 114-161085 (40), 11-7888 (12a), 11-8888 (42), X20-251085 (12a); Morel 3043 (28c); Moreno 43 (6b), 15008 (4), 15144 (9), 17034 (6c), 19574 (10), 2191223184 (8), 23640, 23640, 23685, 23708 (3), 23864 (40), 24238 (6b), 24256 (6b), 25047 (6b), 26755 (9); Moreno \& Henrich 8843 (6b); Moreno \& Robleto 20468 (6c); Moreno \& Sandino 6472 (6b); Mori \& Benton 12955 (2); Mori \& Bolten 7260 (6c); Mori \& Boom 14110 (40), 14720 (1), 14845 (42); Mori \& Cardoso 17581 (64); Mori \& Carvalho 12009 (30); Mori \& Fernandez 19791 (1); Mori \& Gracie 18320 (37), 18330 (10), 186672 (21a), 18671 (37), 21165 (64), 21744 (21a), 23886 (64); Mori \& Kallunki 4695 (36), 4878 (4), 4975 (63), 5679 (6c); Mori \& Pepper 24300 (64); Mori \& Pipoly 15615 (10), 15626 (21a); Mori \& Santos 10124 (28b); Mori et al. 8173 (21a), 9092 (42), 9820, 9821 (40), 11570, 15087 (10), 15113, 15685 (42), 17178 (21a), 19411 (1), 20963 (19), 21325 (68), 22028, 22213 (21a), 24090 (64), 24527 (21a); Mostaceda \& Foster 38 (28e); Mowbray 703131 (10); Moya \& Reyes 187 (39); Mutchnick 946 (21a), 1585 (40).

Nascimento et al. 7 (39), 590 (47); Native collector 3-10 (18); Nee 11503 (12a), 26702, 28406 (4), 29761 (sp.), 34935 (28a), 34987 (6a), 36836 (12a), 38084, 38683, 38723, 38724, 38839, 39275, 39739 (28e), 41011, 41851, 41884, 41961, 42702 (16), 42759 (16), 45246 (10), 9808 (63); Nee \& Saldias 35938 (10), 36877 (12a); Nee \& Tellez 28118 (42); Nee \& Tyson 10989 (54), 10993 (42); Nee et al. 26677 (6f); Neill 4192 (12a), 5116 (63), 8554 (42), 8554 (42); Neill \& Gomez 6417 (40); Neill \& Hurtado 8765 (10); Neill \& Palacios 6660 (40), 6704, 6814 (10), 7310, 7639 (21a); Neill \& Quizhpe 15041 (sp.); Neill \& Vincelli 3474 (9); Neill et al. 6232 (40), 6240 (37), 6311 (10), 6315 (1), 6372 (42), 6859 (28e), 6890 (42), 6901 (40), 7395 (10), 7478 (28d), 7924 (28a), 7959 (1), 8249 (1), 8602 (38), 11203 (1), 11672 (6a), 12696 (20); Nelson 4222, 4230 (6b); Nelson \& Romero 4711 (6d); Nelson \& Vargas 5087 (42); Nelson et al. 5885 (6d); Neverman 1926 (sp.); Nevers 3778 (8); Nevers \& Herrera 4474 (13), 6626 (63), 7096 (42); Nevers et al. 4969 (63), 5202, 5366, 5869 (54), 6400 (63), 8338, 8386 (28e); Nevling \& Gomez-Pompa 2530 (6f); Nicolalde et al. 1251 (27); Nicolson 2111 (6a); Nunez 1819 (28a), 12261 (6b); Nunez \& Yagual. 249 (6a); Nunez et al. 10205 (6c), 14821 (28d).

Oersted 80 (4), 82, s.n. (6b); Oldeman 1221 (28d), 1330 (21b), 1706, 2331 (21a), 2794 (37), 3114 (42), 3340 (21a), B1017 (18), B1109 (1), B1169, B1416 (21a); Oldenburger et al. 1254 (16), ON 942 (40), ON 436 (21a); Oliveira de 2240 (28b), 344A, 647, 647B, 65E (31); Oliveira et al. 164 (55), 446 (25a?), 465 (16); Ollgaard et al. 35166 (12a); Opler 1755 (6b); Ortega 5347 (6b), 673 (40); Ortiz 367 (40), 726 (12a), 938 (6f), 1005 (12a), 1006 (6f), 2135 (40); Ortiz \& Basualdo 715 (28c); Ortiz \& Zardini 653, 667, 669 (28c); Ortiz et al. 37 (6c); Pabon et al. 296 (40); Pacheco et al. 118 (55), 223 (50); Palacios 1426 (39), 1633 (33), 1832 (12a), 1846, 2008 (10), 2026 (28e), 2074, 2101 (1), 2802 (37), 3157 (1), 3193 (33), 3209 (28a), 4424 (39), 4661 (38), 5112 (39), 5543, 5665, 5750, 5754, 5768, 5774 (38), 6613, 6617, 8439, 8444 (35), 8460 (35), 12097 (27), 12240 (10), 13495 (9?).

Palacios \& Freire 5150 (39); Palacios \& Iguago 4557, 4561 (38); Palacios \& Neill 588, 654 (10), 694 (1), 716 (21a), 901 (37), 944 (28e), 953 (12a), 957 (27), 958 (1), 1272 (27); Palacios \& 
Rodríguez 76 (28d); Palacios \& Rubio 9971 (6a); Palacios \& Tipas 9135 (34); Palacios \& Tirado 13112 (20); Palacios et al. 243 (10), 281 (28e), 351 (40), 466 (12a), 497 (10), 869 (28e), 959 (10), 997 (1), 1053 (42), 1057 (28e), 1180 (27), 1285 (33), 4416 (10), 7605 (21a), 7904 (28e), 8161 (41), 9466 (41), 9526 (28e), 10441 (16?); Palmer 391, 578, 1391 (6b); Palomares 4-B (39); Panero \& Calzada 5527 (7?); Paniagra et al. 1128 (10), 2018 (21a); Pardo et al. 114 (28a); Pastore \& Klein 59 (40); Pastore et al. 9109 (40); Pavon s.n. (6b); Peck 801 (6d); Pedersen 7113, 8528, 8624 (28c); Peña 2 (28e), 122 (39), 163 (10); Peña \& Foster 237 (28b); Pendry 82204 (28a); Penneys 263 (10), 451 (4), 571 (6c); Pennington 10154 (10), 10158 (6b), 10591 (28e), 10593 (12a), 10631 (28e), 10640, 10648 (10), 10650 (42); Pennington \& Budowski 10106 (12a), 10108 (9), 10116 (10), 10120 (42), 10121 (6c); Pennington \& Criollo 12413 (68); Pennington \& Cruz 10527 (44); Pennington \& Daza 16807, 17198 (10); Pennington \& la Cruz 10561 (10); Pennington \& Mori 12110, 12118 (19), 12141 (21a), 12182 (10); Pennington \& Poveda 10128 (7), 10142 (8), 10143 (10), 10148 (6c), 10150 (63), 11439 (63), 11475 (63); Pennington \& Ramos 10052 (10); Pennington \& Santos 10166 (28d); Pennington \& Sarukhan 9162 (4), 9174 (6d), 9177 (42), 9294 (6f), 9578 (4); Pennington \& Tenorio 10730, 10730 (40), 10737 (28e), 10771 (10), 10797 (1); Pennington \& Veloz 14005, 14026 (28e); Pennington \& Zamora 13343 (54); Pennington et al. 9900 (1), 9908 (55), 9920 (18), 9922 (16), 9958 (64), 9962 (68), 9966 (28d), 9967 (47), 9977 (1), 9978 (47), 9981 (21b), 9990, 9995 (55), 10056 (17), 10060 (18), 10061 (28d), 10066 (10), 10068 (69), 10071 (18), 10072 (64), 10074 (17), 10076 (1), 10078 (16), 10080 (28d), 10081 (37), 10083 (28d), 10087 (21a), 10089 (42), 10095 (12a), 10097 (10), 11366 (36), 12206 (10), 12208 (28e), 12229 (27), 12250 (1), 12274 (40), 12293 (39), 12330 (10), 12467 (21a), 12544, 13478 (28d), 13676 (6d), 13945 (28a), 13995 (4), 14019, 14020, 14021, 14071 (28a), 14080 (4), 14241 (28d), 14928 (9), 14937 (28d), 15005 (9), 16514 (21a), 17066 (58), 17139 (sp.), 17417 (18); Pennington $R$ T et al. 13 (39), 136 (28a), 161 (40), 169 (39), 34 (10); Pequeno \& Costa 246 (28b); Pereira 335 (28b), 1083 (40), 2247 (10); Pereira \& Alvarenga 2216, 3052, 3225, 3332 (40); Pereira \& Alvarengo 2391 (10); Pereira et al. 1695 (28e), 2758 (40); Perez 120 (28c); Perrottet s.n. (6a), s.n. (26); Peters 54 (28e); Petrov 132 (42); Philipson et al. 1489 (21a); Pinheiro 2079 (28d), 2092 (2); Pinheiro \& Santos 458, 2285 (28d); Pipoly 3515 (42), 11276 (40); Pipoly \& Lall 8154, 8191, 8210, 8273 (40); Pipoly et al. 6922, 6925 (40); Pirani \& Yano 766, 795 (28b); Pirani et al. 4745, 4851, 7610 (40), 7642 (28a); Pires \& Martin 10055 (40); Pires J M et al. 37384 (21b), 50324 (21a), 50439 (64), 50454 (21a), 50676 (64), 50879 (28d), 50920 (21a), 50947 (64), 51191 (42), 51226 (28d), 51308 (10), 51319 (64), 51487 (42); Pires J M \& Silva 11488 (10); Pires J M et al. 50575 (6a); Pires M J \& Silva 1483 (1), 2000 (39), 2009 (10), 2011 (28d); Piretta 896 (28b); Pitman 550 (10), 554 (37); Pittier 5466 (6a), 5580 (42), 5697 (42), 12093 (51), 13226 (9); Plowman et al. 6697 (37), 8382 (10), 9821 (1), 28993 (37); Poeppig 2006 (68), 2261 (45), 2653 (10); Poiteau s.n. (10); Prance \& Pennington 1788 (10), 1929 (16); Prance \& Ramos 23300 (40), 6938 (16); Prance \& Silva 59417 (28c), 59579 (10); Prance et al. 1618 (28d), 2670 (1), 2811 (39), 2837 (57), 3016 (50), 3061 (50), 4202 (21a), 4369 (40), 6149 (21b), 6498 (37), 7329 (12a), 7733 (10), 7992 (34), 8199 (21a), 8753 (37), 9311 (40), 9655 (40), 9850 (6a), 10033, 10353 (40), 10408), 10778 (25), 11015 (10), 11038 (25), 12578 (10), 1337 (40), 1408 (1), 14162 (21b), 15112 (21b), 15615 (25), 15750 (21b), 16411 (69), 18374 (10), 19010 (40), 24283 (18), 24503 (40), 24730 (1), 2536 (39), 25788, 29462 (25), 30216 (64), 30261 (39), 30263 (10), 30266 (28a), 30291 (39), 30299 (10), 30434 (39); Prescott \& Watkins 111 (39); Prévost 2211 (19), 3029 (42), 3631 (40), 4165 (21a); Prévost \& Grenand 1965 (21a), 4329 (12?); Prévost \& Sabatier 2745 (10), 2814 (21a); Pringle 7074 (6b); Prior 772 (6a); Proctor 9870 (11), 18909 (28a), 23188 (11), 24023 (6a), 36079 (6d), 38428 (11); Pulle 324 (37); Purpus 5953 (6d), 7374 (6b?).

Queiroz et al. 2784, 2785 (28b); Quelal et al. 439 (10), 625 (44); Quesada 1121 (8); Quevedo et al. 838 (40); Quipuscoa 233 (28e); Quiroz 202 (6c); Quizhpe et al. 317 (sp.), 466 (12a), 500 (39), 620 (1).

R M P \& M s.n. (6a); Rabelo \& Cardozo 2685 (10), 2688 (40); Rabelo et al. 2264 (40), 3046 (21a), 3086, 3125 (64), 3184 (10), 3701 (39), 3704 (10), 3713 (37); Ramage s.n. (6a); Ramalho \& 
Pinheiro 2863 (10), 2864 (40), 2866 (28b), 2868 (40), 2875 (40), 2876 (29), 2881 (40), 2888 (28b); Ramirez s.n. (40); Ramirez et al. 228 (6e), 5589 (21a); Ramos et al. 6890 (10); Raven 21684 (8), 21911 (10); Regnell 2-38 1/2 (10); Rehder 1129 (40); Reineck s.n. (28b); Reitz C1433 (28b); Reitz \& Klein 12165 (10), 15323 (28b), 7506 (28b); Reko 3701 (6a), 4896 (6e), 6078 (6b); Renteria et al. 2819 (36); Restrepo \& Matapi 390 (68), 526 (69?); Rev L Gsn (6a); Revilla 859 (40), 978 (21a), 982 (57), 1187 (57), 2087, 3668, 3690 (34), 3691 (1), 4302 (42); Reyna 1454 (5); Reynel 1271 (10), 1273 (40); Ribeiro \& Pereira 1873 (1); Ribeiro \& Silva 1523 (1); Ribeiro et al. 862 (1), 1115 (28a), 1139, 1594 (1), 1620 (68), 1698 (47), 1901 (64); Rico et al. 2022 (40); Riera 688 (21a), 733 (42), 759, 760, 762 (37), 789 (42), 1450 (37); Rimachi 107 (21a), 468 (17), 634, 736 (28e), 1246 (10), 1903 (28e), 2395 (39), 2915 (21a), 3050 (34), 3062 (21a), 3349 (28e), 4322 (68), 4385 (39), 4461 (6a), 4494 (10), 4501 (1), 11842 (57), 12160 (57); Rios 267 (7); Rivera 1098 (8), 1946 (6c), 545 (9), 983 (42), 990 (10); Rivera \& Dennis 1103 (12a); Rivera \& Hoomans 1765 (4); Rivera et al. 2075 (6c); Rivero et al. 264 (10), 277 (28d); Robles et al. 1154 (63), 2016 (53); Robleto 325 (6b), 741 (10), 761 (42), 843 (10), 920 (10), 978 (6b), 1208 (6b), 1636 (6b); Rocha 1 (6b); Rodrígues 264 (21a); Rodrígues \& Coelho 1660 (21b); Rodríguez 618 (27), 7015 (51), 8400 (6a), 8481 (40), 8526 (23), 9613, 9614 (66), 9617 (46), 9624 (56); Rodríguez \& Lepiz 9949, 9950, 9951, 9952, 9953 (23); Rodríguez et al. 139 (46), 193 (9), 1467 (21a), 2140 (51), 6121 (22), 6238 (23); Rojas et al. 45 (32), 56 (34); Romero-Castañeda 813 (40), 5519 (13), 11180 (40); Romoleroux \& Foster 2495 (28e); Romoleroux \& Pitman 2292 (34); Romoleroux \& Villa 2390 (34); Rosales 772, 838, 901 (6b); Rosas 1645 (4); Rossi et al. 575, 679 (28b); Rothschild \& Upson 328 (6b); Rothschild et al. 184 (6b); Rovirosa 398, 542 (6f); Rubio \& Coba 790 (37); Rubio \& Gudiño 183 (28d); Rubio et al. 1808 (6c); Rudas \& Prieto 3164 (33); Rudas et al. 2409 (17), 3680 (39); Rueda \& Ruiz 693 (34); Rueda et al. 1903 (6a), 16502, 16503 (6b); Ruiz \& Campos 1712 (28d); Ruiz et al. 1553 (21a); Ruiz J 561 (1); Rusby 1296 (40), 2590 (28d), 797 (28e); Rusby \& Squires 175 (40); Rutkis 472 (28a); Ryan s.n. (6a), s.n. (28a).

Sabatier \& Gonzalez 5399 (68); Sabatier \& Prevost 4082 (21a), 4111 (37), 4241 (42); Sabatier et al. 4714 (1); Saborio et al. 121 (12a); Salas et al. 2793 (6b); Salcedo 208 (40); Saldias \& Lawrence 1435 (40); Saldias et al. 3373 (40); Salino 3562 (10), 3730, 3928 (28a); Salino \& Morais 4489 (28b); Salino et al. 4059 (10), 4201 (10); Sampaio et al. 184, 52 (28b); Sanders et al. 10607 (6b), 19289, 19313 (10); Sandino 2865 (42), 3236 (6b), 3445 (9), 4267 (10), 4474 (9), 4617, 4658 (42), 4933 (4), 5169 (12a); Sandino \& Martinez 4371 (6b); Sandoval. 1036 (6a), 1766 (6b); Sandoval.\& Chinchilla 10 (6a); Santamaria \& Lara 1098 (9); Sant'Ana et al. 360 (30); Santisteban \& Guevara 152, 154 (10); Santos 1482 (40); Santos dos et al. 479 (40); Santos dos G et al. 89 (10); Santos T S 1241 (10); Sasaki et al. 1670 (14), 1737 (14), 2089 (14); Sastre 747, 1435 (40), 3899, 4630 (21a); Sauvain 460 (21a); Schinini \& Bordas 5082, 25091, 25122 (10); Schipp 414 (6d), 452, 952 (42), 1001 (6f), 1070 (6d); Schmalzel \& Todzia 2053 (6c); Schnell 11871 (21a); Schomburgk 583 (40), 779 (6a); Schultes 3380 (40), 3532 (21a), 4092 (40), 46-303 (41); Schultes \& Pires 9145 (10); Schulz 8151 (64), 8590 (21a), 10196 (10); Schunke 1168 (21a), 1179 (42), 1584 (69?), 2551 (10), 2665 (28e), 2771 (10), 2778 (12a), 4355 (10), 4581 (28e), 5707 (52), 6895 (28b), 7364 (40), 8026 (12a), 8508 (37), 10783 (28e), 10911 (21a); Schwacke 13021 (28b); Secco et al. 236 (28d); SEF 8603 (37), 8728 (33), 8777 (10), 8783 (1), 8848 (39), 8907, 8971 (28e), 9020 (10), 9034 (42), 9046 (10), 9053 (42), 9063, 9112 (12a), 9249 (37), 10008 (28e), 10044 (12a), 10068, 10121, 10147 (28e), 10291 (12a), 10315 (28e); Segura \& Quesada 73 (sp.); Seibert 2134 (40); Seidel 3021 (12a); Seidel \& Schulte 2261 (10); Seidel \& Vaquiata 7543 (28d); Seidel \& Vargas 2130 (28d); Seidel et al. 2877, 4634 (28e), 5369 (10), 5634 (12a), 7323 (28e), 7570 (40); Seidel et al. 8286A (28e); Serato 46, 61 (12a); Sergio et al. 185 (40); Sessé s.n. (6a); Shafer 62, 1543 (40); Shakaim 16 (40); Shank \& Molina 4840 (42); Shapiro \& Elliot 447 (6d); Shepherd 881 (sp.); Silva A S et al. 151 (39), AS143 (1); Silva da 2023 (28b), 2108.412 .2 (25); Silva da \& Lopes 795 (28b); Silva da A V V et al. 2206.1225.2 (50); Silva da et al. 2028 (28b); Silva da S P C et al. 724 (10); Silva E \& Lima 5809 (40); Silva M G \& Rosario 3940, s.n. (28e); Silva $N T 10$ (28d), 
57777 (1), 57800 (40); Silveira et al. 1140 (10), 1278 (40), 1534 (10), 418 (28a), 460 (28d), 524 (1), 766 (28a); Silverstone 992 (40); Silverstone-Sopkin \& Paz 6783 (28e), s.n. (10); Simonis et al. 238 (10); Sintenis 260, 1215, 1510, 2524, 2860, 4060 (6a), 4280 (40), 4396, 4441 (6a); Skinner s.n. (4); Skutch 1685 (4), 2665 (9), 3621 (7); Smith A 11 (4), 172 (4), 635 (4), 861 (22), 1686 (22), 4108 (7), 4111 (4), 1686 (22); Smith A C 2491 (40), 2715 (1), 2850 (10), 2914 (1), 3435 (40), 10233 (6a); Smith D1877 (40), 1880 (40), 2060 (28e); Smith D et al. 1967 (28a); Smith D N 8440 (28a); Smith D N \& Garcia 14137 (10), 14143 (12a); Smith D N \& Pretel 7609 (10); Smith D N \& Salick 8362 (42), 8384 (40); Smith D N \& Vásquez 4704, 4738 (10); Smith D N et al. 7907, 7944, 8647, 8686, 13912, 14011 (10), 14021 (12a), 14116 (10), 14125, 14178 (28d), 14225 (28a), 14360 (40), 14361 (39); Smith H H407 (40); Smith H H \& GW 532 (6a); Smith J D 2601 (6b); Smith L B \& Klein 13130 (28b); Smith N P 13 (1); Smith S F et al. 962 (6c), 1063 (28d), 1407 (10); Sobel et al. 4788, 4789 (37); Soejarto \& Gennaro 5699 (10); Soejarto et al. 4134 (36); Solano 61 (9); Solomon 5690, 6492 (40), 9116 (10), 13099 (12a), 19302 (9); Solomon et al. 6892 (28c); Soria \& Basualdo 2198 (28c); Sothers 213 (55); Sothers \& Perreira 426 (68); Sothers \& Silva 411 (68), 456 (1), 659 (55); Sothers et al. 551 (28d); Soto \& Rojas 1751 (8); Sousa 3287 (42); Souza 23 (40); Souza \& Silva 33 (1); Soza et al. 97 (6b); Sperling \& King 6440 (39); Sperling et al. 5958 (1), 6138 (10), 6406 (28d); Sperry 736 (9); Spichiger \& Encarnación 1192 (17); Spruce 1686 (21b), 2240 (15), 2316 (1); St Hilaire s.n. (28c), s.n. (28b); Stahl 6701, 6756 (4); Staihl \& Andersson 6290 (28e); Staihl \& Cornejo 6149 (28e); Standley 11228 (6b), 20134 (6a), 21297 (6b), 64991 (6a), 68562 (4), 79645 (6b), 84898 , 85046 (5), 89145 (6b), 89260 (42); Stannard et al. 2617 (40); Stehmann et al. 2969 (28c), s.n. (40); Stein 1402 (40), 3431 (10); Stein \& McDade 3334 (10); Stein \& Suarez 3052 (10); Steinbach 1857 (28e), 5374 (40), 7227 (10); Steinbach R F 518 (12a); Steinmann 4362 (6e); Stergios \& Aymard 9181 (28d); Stergios \& Stergios 11316 (21b), 11408 (21b); Stergios \& Velazco 13953 (28d), 14223 (42); Stergios et al. 9774 (21a), 15215 (28d), 15329 (64); Stern et al. 111, 182 (40), 213 (10), 1090 (6c); Stevens 11647, 22118 (6c), 23428 (sp.), 23712 (9), 23849 (10), 24312 (9), 24355 (54); Stevens \& Montiel 17151 (6b); Stevens et al. 12953 (12a), 18932 (42), 20370 (6c), 21384 (12a), 21471 (42), 25383 (6d); Steward et al. 37 (68); Steyermark 36502, 45739 (4), 46644, 46867 (5), 47632 (42), 49239 (6d), 55850, 61516 (40), 61967 (10), 89059 (6a), 90726 (37), 101532 (21a), 107388 (40), 111544 (10); Steyermark \& Espinoza 123802 (6a); Steyermark \& Liesner 118502 (10); Steyermark et al. 101372 (10), 101950 (40), 119748 (10), 120419 (40), 125860, 125884 (21a), 126183 (40); Steyermark J A \& C 95392 (59); St Hilaire s.n. (28c); Stijfhoorn et al. 877 (28a); Stoffers et al. 215 (40), 215 (40); Strudwick et al. 3419 (6a), 3855 (10); Sucre 484 (28b); Sugden 491 (42); Sugden \& Wint 569 (42); Sytsma \& Andersson 4553 (63); Sytsma \& Andersson 4153 (40), 4716 (63); Sytsma et al. 2490 (sp.).

Tavares 233 (21a), 331 (10); Taylor 143 (40), 10173 (6a); Teixera et al. 236 (21a), 448 (37), 458, 615 (21a); Tellez et al. 7589 (63?); Tello 200 (42), 376 (12a), 419 (39), 1732 (42), 2233 (37), 2829 (42); Temponi 15 (28b); Tenorio et al. 14470 (6d); Teran 2869 (40); Tessmann 3164 (12a), 4156 (27), 4376 (32), 4450 (52); Thomas 6386 (21a); Thomas et al. 4041 (21a), 4347 (10), 4621, 4711 (40), 4973, 4987 (16), 5172 (21b), 5267 (21a), 5306 (25), 5362 (18), 6529 (21a), 10591, 10607 (30); Thomsen 61 (8), 107 (9), 290 (42), 482 (12a), 570 (42), 585 (8), 619 (42), 682 (28e), 863 (10), 882 (42), 1622 (28e), 1623 (9), 58825 (6c), 58856 (44); Thomsen \& Korning 1445 (9); Thorne \& Proctor 48229 (6a); Tipaz 2480, 2652 (61), 2721 (10); Tipaz \& Quelal. 181 (44); Tipaz et al. 378 (38), 1296 (44), 2276 (61), 2283 (61), 2387 (9); Tirado et al. 1223 (10), 370 (9); Tiwari \& Mangharini 401 (40); Toasa \& Tirado 8731 (27); Ton 4342, 4374 (8?), 6345 (6f), 7434 (8?); Tonduz 11306 (63), 12592 (6c), 12838 (9), 13114 (6c), 17677 (7); Tonduz \& Pittier 13112 (4), 13114 (6c); Torres \& Campos 10840 (6d?); Torres \& Tenorio 209 (6b); Tressens et al. 3505 (28c), 3508 (28c); Triana 3359 (6b), 3360 (10); Trigos 195 (9); Trigos \& Calzada 114 (4), 155 (9); Trusty 208 (6c); Tunqui 56 (32), 225 (40), 333 (27), 646 (28e), 778 (28e); Tyson 6802 (40).

Ule 8187 (40), 9509 (10), 9512 (28e); Uribe 4284 (10); Urrego et al. 544 (39); Utley J \& K 1246 (8), 3918 (4), 3955 (9), 4601 (7), 5572 (6c). 
Valcarcel 525 (41); Valdespino et al. 470 (8), 583 (8); Valerio 1173 (63), 298 (67); Valverde 838 (8); Valverde et al. 1157 (67); van Andel et al. 393 (10); van der Werff \& Hardeveld 6734 (7); van der Werff \& Palacios 9233 (20); van der Werff et al. 9917, 9930 (10), 9934 (37), 10023 (16), 12197, 12215, 12437, 13014 (10), 13184 (28e); van Rooden 804 (6f), 804 (sp.); Vanni \& Radovancich 1006 (28c); Vanni et al. 951, 1404 (28c); Varela 54 (40); Vargas 1233 (56), 23928 (28a); Vargas \& Alvarado 1022 (10); Vargas \& Frazee 47 (63); Vargas \& Tagua 2757 (28e); Vargas et al. 1049 (21b), 248 (9), 624 (10), 633 (42); Vásquez 10615 (39), 10660 (28a), 10666 (39), 5003, 6830 (28a), 7122 (57); Vásquez \& Criollo 1783 (28d); Vásquez \& Jaramillo 552 (42), 830 (37), 846 (10), 1614 (28e), 2351 (40), 2362 (10), 2454 (32), 2618 (21a), 2620 (1), 3372 (37), 3376 (10), 3549 (1), 3587 (42), 3764 (10), 3972 (10), 4094 (10), 4117 (28e), 4546 (10), 4609 (17), 4710 (34), 4924 (1), 6015 (42), 6151 (10), 6274 (41), 6329 (41), 6333 (41), 6360 (28e), 6820 (10), 76 (28e), 7967 (1?), 8433 (27), 9219 (64), 9377 (10), 9410 (37), 9421 (10), 10108 (41), 10482 (10), 10571 (sp.), 10974 (68), 13655 (68), 20267 (32), 20317 (12a); Vásquez \& Ruiz 2963 (37); Vásquez \& Soto 8324 (33); Vásquez et al. 43 (6d), 427 (4), 910 (6d), 1020 (1), 10691 (42), 2809 (34), 2998 (10), 3401 (10), 4004 (68), 4026 (28a), 4311 (10), 4700 (10), 5143 (37), 5174 (42), 5929 (10), 5936 (39), 5984 (10), 6379 (28e), 6425 (28e), 6599 (33), 6599 (42), 13825 (57), 16629 (17), 17920 (sp.), 18337 (34), 19026 (35), 19917 (25), 21031 (39), 21282 (28d), 21297 (39), 22169 (32), 22284 (27), 22627 (35), 24055 (35), 24209 (18), 24209 (sp.), 24227 (21a), 30397 (28e), s.n. (28e); Vázquez 505 (6f); Velásquez 14 (6b), 30 (6b); Velásquez et al. 182 (4?); Veliz 95.5025 (6a); Ventur 173 (6d); Ventura 1000 (6d); Ventura \& Lopez 220 (42); Vianna et al. 1475, 1499, 1605, 1959 (40); Vicentini \& Silva 424 (1); Vieillescazes 519 (10); Vieira et al. 345 (39); Villa \& Velez 1085 (28e), 1085 (sp.); Villa et al. 814 (37); Villacorta \& Lara 2650 (5); Villacorta \& Reyna 1228 (6a); Villacorta et al. 2694 (6b); Villalobos 42 (4?); Villegas 1 (6f), 81 (9); Villiers 2190 (21a); Villiers \& Feuillet 1852 (37), 1941 (1), 2054 (1); Von Linsegen \& Sonehara 588 (28b); Von Tuerckheim 1883 (42), 7835 (6d).

Wachter 105 (42); Wallnöfer 113-31788 (40), 13-4688 (12a), 13-61088 (sp.), 14-121188 (10), 14-231188 (10), 16-4688 (12a); Wallnöfer \& Tarin 13497 (10); Wallnöfer et al. 5963, 9694 (6f); Walter et al. 2563, 2764 (40), 2765 (10), 2865 (28b), 3182 (10), 3335, 4014 (40), 4242 (10); Warming 3213 (28b); Weberbauer 1923 (10); Webster 13530 (6a); Wedel 2874 (42); Wendland 755 (54); Wendt et al. 2539 (4), 3147 (4), 4892 (6d); Werff van der \& Palacios 9233 (20); Werff van der et al. 9571 (44), 9837 (17), 10124 (17), 10247 (57), 19131 (28e), 19165 (28e), 19177 (1); Westra 48524 (10); Whitmore 864 (40); Williams 15205 (40), 1740 (28d), 6537 (28d), 8783 (6d); Williams \& Molina 11342 (42), 15181 (6a); Williams \& Stone 10216 (9); Williams et al. 26591 (4); Williams L 9975 (40); Williams L O et al. 23480 (6c), 24843 (6c); Williams Ll 1232 (21a), 13333 (40), 2279 (28e), 3474 (42), 4337 (42), 4563 (10), 5333 (12a), 6222 (28d?); Williams $R O$ 12181 (6a); Williams R S683 (10); Witherspoon J \& F 8587 (sp.); Witsberger s.n. (6b); Woods \& Gallegos s.n. (6a); Woodson \& Schery 587 (6c); Woolston 621 (28c); Woytkowski 5511 (28e), 5965 (12a), 7297 (40); Wurdack 2071 (28e), 2127 (6c), 2334 (10), 2422 (12a); Wurdack \& Adderley 43031 (21b); Wurdack \& Guppy 211 (40); Wurdack \& Monachino 41135 (40).

Yanez 495 (64); Young 174, 177 (28a); Young \& León 5015 (10); Young \& Salazar 1024 (28a); Yuncker et al. 8442, 8706 (6d).

Zak \& Espinoza 4806 (37), 4808, 4817, 5000, 5030, 5051, 5056, 5121, 5150 (10); Zak et al. 5462, 5475, 5719 (9); Zamora 965 (8); Zamora \& Chavarria 2208 (10); Zamora \& Sanchez 445 (63); Zamora et al. 2416 (6b), 2478 (63), 2535 (54); Zardini 4960 (28b), 7137, 7210, 7359, 7428, 7548, 7661, 7888 (28c), 7956 (10), 8026, 8232 (28c), 10956 (10), 11010, 11347, 12632 (28c), 13397 (10), 14346, 14347 (28c), 14784 (10), 14972 (28c); Zardini \& Aguayo 15816 (28c), 8414, 8542, 8549 (10), 11181 (28c), 14074 (10), 14087, 14087, 14793 (28c), 14869 (10), 14891, 14898 (28c); Zardini \& Benitez 3161, 47465 (10); Zardini \& Cardozo 44962 (28c), 45094 (40), 45095 (10), 45102 (28c); Zardini \& Chaparro 48606 (28c); Zardini \& Degen 3755 (28c); Zardini \& Florentin 7002 (28c); Zardini \& Gamarra 51888 (28c); Zardini \& Garcete 43331, 43447 (10); 
Zardini \& Guerrero 40111, 42693, 56815, 56815 (28c); Zardini \& Hellman 48976 (28c), 49000 (10); Zardini \& Jara 36521 (28c); Zardini \& Quintana 53819 (28c); Zardini \& Tilleria 37437 (28c); Zardini \& Velasquez 11049, 11366 (10), 12042, 12177, 12209, 12466, 12564, 13219 (28c), 13319 (10), 13618 (28c), 13644 (10), 13761 (28c), 13795 (10); Zardini \& Velasquez 13819 (28c), 13976 (10), 14252 (28c), 14256, 14606 (10), 14618 (28c), 14635, 15073 (10), 15111, 15113, 15122 (28c), 15125, 15173, 15177 (10), 15203, 15304, 15420, 15552, 15633, 15661, 15704, 15719, 15776, 16034, 16102, 17497, 18226, 18226, 18237, 18727, 20447, 20976, 21667, 21710 (10), 21735, 21955, 22120, 22570, 23804, 8926 (28c); Zardini \& Vera 42606 (10); Zardini \& Zavala 46739 (28c); Zardini et al. 11780, 15438, 3022 (28c); Zarucchi 2195 (28e); Zarucchi \& Balick 1768 (41); Zarucchi \& Echeverry 4718 (10); Zarucchi et al. 3020 (21b); Zaruma 297 (40), 443 (42), 590 (37), 683 (28d), 791 (37); Zaruma \& Arguello 500 (28e); Zaruma et al. 35 (37), 48 (10), 135, 146 (40), 164, 166 (1); Zuleta 4 (40), 6 (28a), 10 (16), 128 (1), 28 (10), 312 (28a); Zuniga 524 (28e); Zuniga et al. 376 (66); Zuzepczuk s.n. (6d).

\section{APPENDIX 1 \\ List of Guarea DNA vouchers}

G. anomala 30514 Brazil, Mori \& Benton 12995 GenBank HE653770

G. bijuga 29879 Belize, Pennil 11 GenBank HE653766

G. blanchetii 30515 Brazil, Jardim et al. 225 GenBank HE653726

G. blanchetii 30516 Brazil, Sant'ana et al. 360 GenBank HE653727

G. blanchetii 30517 Brazil, Kallunki et al. 515 GenBank HE653728

G. bullata 25921 Mexico, Cedillo Trigos 31 GenBank HE653765

G. carapoides 30519 Peru, Vásquez \& Jaramillo 20267 GenBank HE653730

G. carinata 25857 Ecuador, Freire \& Cerda 149 GenBank HE653731

G. caulobotrys 30527 Panama, McPherson 11866 GenBank HE653746

G. chiricana 25922 Panama, Foster 2928 GenBank HE653767

G. cinnamomea 25859 Peru, Pennington et al. 17417 GenBank HE653732

G. costata 25860 French Guiana, de Granville et al. 8072 GenBank HE653733

G. cristata 30520 Peru, Vásquez \& Jaramillo 4609 GenBank HE653734

G. cristata 30521 Colombia, Duivenvoorden et al. 2766 GenBank HE653735

G. ecuadoriensis 30522 Ecuador, Palacios 3193 GenBank HE653736

G. fissicalyx 25861 Peru, McDaniel \& Rimachi 23667 GenBank HE653737

G. fistulosa 25871 Peru, Revilla 3668 GenBank HE653748

G. gentryi 30518 Colombia, Fuchs \& Zanella 22361 GenBank HE653764

G. glabra subsp. glabra 25929 El Salvador, Martinez 694 GenBank HE653761

G. glabra subsp. microcarpa 25934 Peru, Wurdack 2127 GenBank HE653762

G. glabra subsp. microcarpa 25936 Ecuador, Thomsen 58825 GenBank HE653763

G. gomma 25862 Ecuador, Baker 5917 GenBank HE653738

G. gracilis 30523 Brazil, Oliveira 344A GenBank HE653739

G. grandifolia 3819 Peru, Pennington 10093 GenBank HE653725

G. guentheri 25864 Ecuador, Toasa \& Tirado 8731 GenBank HE653740

G. guidonia 30524 Ecuador, Pabón et al. 296 GenBank HE653741

G. jamaicensis 25866 Jamaica, Goodfriend s.n. GenBank HE653758

G. kunthiana 25967 Peru, Pennington \& Daza 16807 GenBank HE653759

G. luxii 25943 El Salvador, Monterrosa et al. 186 GenBank HE653769

G. macrocalyx 33283 Costa Rica, Kernan 1214 GenBank HE653742

G. macrophylla 25870 Paraguay, Zardini \& Zavala 46739 GenBank HE653729

G. michel-moddei 30526 French Guiana, Cremers \& Gautier 11959 GenBank HE 653745 
G. pendula 30528 Brazil, Mexia 4555 GenBank HE653747

G. persistens 25872 Ecuador, J.L. Clark 2298 GenBank HE653749

G. pterorhachis 25873 Brazil, Campbell et al. 8935 GenBank HE653758

G. pubescens 25875 Peru, Pennington et al. 16514 GenBank HE653750

G. purusana 25876 Bolivia, Cardiel \& Carballal 139 GenBank HE653751

G. pyriformis 25877 Costa Rica, Harmon 33 GenBank HE653752

G. riparia 30529 Ecuador, Palacios 6613 GenBank HE653753

G. silvatica 25879 Brazil, Sothers \& Silva 456 GenBank HE653771

G. sprucei 25881 Brazil, Daly et al. 5452 GenBank HE653754

G. subandina 30530 Ecuador, Chimbo \& Chambo 34 GenBank HE653755

G. tafae-malekui 33285 Costa Rica, Funk et al. 10772 GenBank HE653743

G. tonduzii 25949 Costa Rica, Gentry et al. 71564 GenBank HE653768

G. velutina 25862 Brazil, Cid Ferreira et al. 7945 GenBank HE653756

G. zarceroensis 25951 Costa Rica, A. Smith 1686 GenBank HE653744

G. zepivae 33827 Brazil, Sasaki et al. 2089 GenBank HE653757

Heckeldora staudtii (Genbank) Cameroon, Chase 3311 GenBank AY695592

Ruagea pubescens (Genbank) Ecuador, Pennington \& Freire 13761 GenBank AY695593

Turraeanthus sp. (Genbank) Equatorial Guinea, Carvalho 4348-1 GenBank DQ861614

\section{INDEX OF SCIENTIFIC NAMES}

New names are in bold type, synonyms in italics, accepted names in plain type.

Guarea adenophylla Al.Rodr. (7)

Guarea aguilarii Al.Rodr. (43)

Guarea anomala T.D.Penn. (2)

Guarea arcuata Coronado (6c)

Guarea bijuga C.DC. (4)

Guarea blanchetii C.DC. (30)

Guarea brachystachya DC.

Guarea brevianthera C.DC. (6c)

Guarea bullata Radlk. (9)

Guarea carapoides Harms (32)

Guarea carinata Ducke (16)

Guarea cartaguenya Cuatrec. (44)

Guarea casimiriana Harms (45)

Guarea caulobotrys Cuatrec. (13)

Guarea chiapensis Blake (6b)

Guarea chiricana Standl. (8)

Guarea ciliata Al.Rodr. (6a)

Guarea cinnamomea Harms (18)

Guarea constricta Al.Rodr. (46)

Guarea convergens T.D.Penn. (47)

Guarea cook-griggsii C.DC. (4)

Guarea corrugata Cuatrec. (48)

Guarea corticosa Al.Rodr. (49)

Guarea costata A.Juss. (26)

Guarea crispa T.D.Penn. (50)

Guarea cristata T.D.Penn. (17)

Guarea donnell-smithii C.DC. (51) 
Guarea ecuadoriensis W.Palacios (33)

Guarea eriorhachis Harms (52)

Guarea erythrocarpa C.DC. (4)

Guarea excelsa Kunth (6b)

Guarea excelsa Kunth var. dubia Blake (6b)

Guarea filiformis C.DC. (6b)

Guarea filiformis C.DC. var. cinerascens C.DC. (6b)

Guarea filiformis C.DC. var. pallida C.DC. (6b)

Guarea fissicalyx Harms (41)

Guarea fistulosa W.Palacios (34)

Guarea fulva Triana \& Planch. (6b)

Guarea fulva Triana \& Planch. var. mexicana C.DC. (6e)

Guarea gentryi Coronado (3)

Guarea glabra Vahl subsp. glabra (6a)

Guarea glabra Vahl subsp. excelsa (Kunth) T.D.Penn. (6b)

Guarea glabra Vahl subsp. microcarpa (C.DC.) T.D.Penn. (6c)

Guarea glabra Vahl subsp. tuerckheimii (C.DC.) T.D.Penn. (6d)

Guarea glabra Vahl subsp. glabrescens (Hook. \& Arn.) T.D.Penn. (6e)

Guarea glabra Vahl subsp. rovirosae (C.DC.) T.D.Penn. (6f)

Guarea glabrescens (Hook. \& Arn.) Blake (6e)

Guarea gomma Pulle (37)

Guarea gracilis T.D.Penn. (31)

Guarea grandifolia DC. (42)

Guarea grossa T.D.Penn. (53)

Guarea guentheri Harms (27)

Guarea guidonia (L.) Sleumer (40)

Guarea heterophylla Blake (6b)

Guarea hoffmanniana C.DC. (54)

Guarea humaitensis T.D.Penn. (55)

Guarea humilis Bert. ex DC. (6a)

Guarea inesiana Al.Rodr. (56)

Guarea jamaicensis Proctor (11)

Guarea juglandiformis T.D.Penn. (57)

Guarea kegelii Turcz. (6d)

Guarea kunthiana A.Juss. (10)

Guarea lherminieri C.DC. (6a)

Guarea lozanii M.E.Morales (58)

Guarea luciae Barreiros (29)

Guarea luxii C.DC. (5)

Guarea macrocalyx Al.Rodr. (24)

Guarea macropetala T.D.Penn. (54)

Guarea macrophylla Vahl subsp. macrophylla (28a)

Guarea macrophylla Vahl subsp. tuberculata (Vell.) T.D.Penn. (28b)

Guarea macrophylla Vahl subsp. spiciflora (A.Juss.) T.D.Penn. (28c)

Guarea macrophylla Vahl subsp. pachycarpa (C.DC.) T.D.Penn. (28d)

Guarea macrophylla Vahl subsp. pendulispica (C.DC.) T.D.Penn. (28e)

Guarea makrinii Blake (6b)

Guarea matudai Lundell (4)

Guarea megacostata T.D.Penn. (59)

Guarea mexicana Coronado (60) 
Guarea michel-moddei S.A.Mori \& T.D.Penn. (19)

Guarea microcalyx Harms (6a)

Guarea microcarpa C.DC. (6c)

Guarea montana Al.Rodr. (63)

Guarea obtusata Blake (6a)

Guarea palmeri N.E.Rose ex C.DC. (6b)

Guarea pauciflora Sessé \& Moç. (6a)

Guarea pendula R.S.Ramalho, A.L.Pinheiro \& T.D.Penn. (29)

Guarea pendulispica C.DC. (28e)

Guarea penningtoniana M.E.Morales (34)

Guarea penningtoniana Pinheiro (29)

Guarea persistens W.Palacios (38)

Guarea petenensis Coronado (6f)

Guarea pilosa Al.Rodr. (8)

Guarea polyantha Blake (6b)

Guarea polymera Little (61)

Guarea pterorhachis Harms subsp. pterorhachis (12a)

Guarea pterorhachis Harms subsp. submarginalis T.D.Penn. (12b)

Guarea pubescens (Rich.) A.Juss. subsp. pubescens (21a)

Guarea pubescens (Rich.) A.Juss. subsp. pubiflora (A.Juss.) T.D.Penn. (21b)

Guarea pubiflora A.Juss. (21b)

Guarea purpurea C.DC. (6b)

Guarea purusana C.DC. (39)

Guarea pyriformis T.D.Penn. (36)

Guarea quadrangularis M.E.Morales (18)

Guarea ramiflora Vent. (6a)

Guarea reticulatovenosa T.D.Penn. (62)

Guarea rhopalocarpa Radlk. (63)

Guarea riparia W.Palacios (35)

Guarea rovirosae C.DC. (6f)

Guarea scabra A.Juss. (64)

Guarea schomburgkii C.DC. (6a)

Guarea silvatica C.DC. (1)

Guarea sphenophylla Urb. (65)

Guarea spiciflora A.Juss. (28c)

Guarea sprucei C.DC. (15)

Guarea subandina W.Palacios (20)

Guarea subsessilifolia Al.Rodr. (66)

Guarea swartzii DC. (6a)

Guarea syringoides C.H.Wright (6a)

Guarea tafae-malekui Al.Rodr. (23)

Guarea talamancana Gómez-Laur. \& M.Valerio (67)

Guarea ternifoliola C.DC. (6a)

Guarea tonduzii C.DC. (7)

Guarea trichilioides L. var. pachycarpa C.DC. (28d)

Guarea trunciflora C.DC. (68)

Guarea tuberculata Vell. (28b)

Guarea tuerckheimii C.DC. (6d)

Guarea vahliana A.Juss. (6a)

Guarea velutina A.Juss. (25) 
Guarea venenata T.D.Penn. (69)

Guarea virescens C.DC. (6b)

Guarea zarceroensis Coronado (22)

Guarea zepivae T.D.Penn. (14)

Samyda guidonia L. (40)

Sapindus glabrescens Hook. \& Arn. (6e)

Trichilia pubescens Rich. (21a) 